\author{
Universidade de São Paulo \\ Faculdade de Filosofia, Letras e Ciências Humanas \\ Departamento de História \\ Programa de Pós-Graduação em História Social
}

Fábio Augusto Morales Soares

\title{
A DEMOCRACIA ATENIENSE PELO AVESSO \\ Os metecos e a política nos discursos de Lísias
}

São Paulo

2009 


\author{
Universidade de São Paulo \\ Faculdade de Filosofia, Letras e Ciências Humanas \\ Departamento de História \\ Programa de Pós-Graduação em História Social
}

\title{
A DEMOCRACIA ATENIENSE PELO AVESSO \\ Os metecos e a política nos discursos de Lísias
}

\section{Fábio Augusto Morales Soares}

\author{
Dissertação apresentada ao Programa de \\ Pós-Graduação em História Social do \\ Departamento de História da Faculdade de \\ Filosofia, Letras e Ciências Humanas da \\ Universidade de São Paulo, para obtenção do título \\ de Mestre em História.
}

Orientador: Prof. Dr. Norberto Luiz Guarinello

São Paulo

2009 
Para minha avó, Leonor, minha tia, Clarice, e minha mãe, Cleusa. 


\section{Agradecimentos}

Gostaria de agradecer a todos que me acompanharam e contribuíram para que a jornada do mestrado fosse possível. Farei o máximo para me lembrar de todos, mas já digo que boa memória não é a minha melhor qualidade!

À minha família, que suportou a minha ausência mas que nunca foi ausente para mim: Leonor, Clarice, Cleusa, Lia, César, Elaine, Patrícia, Stephany, Júlio César, Rafael, Marcos, Matheus, e para o meu irmão Júnior, que me passou em altura durante os anos de mestrado!

À Cynthia, que agüentou todas as fases e todas as intensidades, que debateu praticamente todas as passagens desta dissertação, que revisou o texto final, e que tornou a vida tão melhor, a cada segundo, a cada eternidade.

Aos meus amigos da graduação, que me formaram não só como pesquisador, mas também como pessoa: Rosa Maria, Rosa Helena, Marcius, Rafael, Karina, Gilberto, Tatiana, Denis, René, Marcão.

Aos meus amigos do LEIR: Gustavo, Uiran, Camila, Joana, Bruno, Marinalva, Victor, Marcos, Juliana, Alex, Ivana, Fábio Faversani, Fábio Joly.

Aos meus amigos de outras paragens: Cristiano, Thiago, Washington, Mani, Moacir, Ariane, Joice, Edgar, Manolo, Érica, Itcha, Émerson, Rafael, Maurício, Júnior, Pola, Julinho, Marcelo, Márcia, Edmilson, Elton, Massayuki, Robson, Cris, Guedes, André, Lara, Fernando, Marcus e tantos outros.

A todos os funcionários de bibliotecas e faculdades, que facilitaram a pesquisa.

Aos professores que contribuíram diretamente com sugestões e críticas valiosíssimas: Jorge Grespan, Breno Sebastiani, Maria Beatriz Florenzano, Elaine Hirata, Marta Mega de Andrade, Marlene Suano, Júlio Groppa Aquino, Amélia Luisa Damiani e Dieter Heinneman.

Ao Norberto, pela orientação sempre presente, pela paciência com as minhas fases (a marxista, a foucaultiana, a anarquista, a hegeliana, a do grupo Krisis... e todas juntas, porque nenhuma passou!), por estar sempre disposto a discutir, por não ser condescendente com nenhuma imaturidade minha, por ter me ensinado a questionar, pela generosidade sem limites, pela amizade... espero com essa dissertação contribuir para o perguntismo norbertiano!

À Fundação de Amparo à Pesquisa do Estado de São Paulo, pela concessão da bolsa de mestrado e o apoio financeiro para a realização do estudo. 
Os cacos da vida, colados, formam uma estranha xícara.

Sem uso,

ela nos espia do aparador.

Carlos Drummond de Andrade, Cerâmica. 


\title{
Resumo
}

Esta dissertação consiste em uma investigação cujo objetivo é examir o tema da participação política dos metecos atenienses, através da análise dos discursos forenses de Lísias e da crítica da historiografia. Alguns conceitos são discutidos, como identidade, espaço, memória, Estado, vida cotidiana, reprodução social, poder, liberdade etc, como um meio de se acessar a complexidade da sociedade ateniense.

Palavras-chave: Metecos Atenienses; Lísias; Democracia Ateniense; Política; Historiografia.

\begin{abstract}
This dissertation consists in a investigation which aims to examine the issue of the political participation of Athenian metic in Classical Athens, through the analysis of the Lysias' forensic speeches and the critique of the historiography. Some concepts are discussed, like identity, space, memory, State, everyday life, social reproduction, power, freedom etc, as a way to have access to the complexity of Athenian society.
\end{abstract}

Keywords: Athenian metics - Lysias - Athenian Democracy - Politics Historiography. 


\section{Sumário}

Numeração dos discursos e fragmentos do Corpus Lysiacum

Introdução

Os Trinta e a restauração

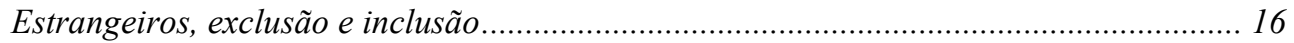

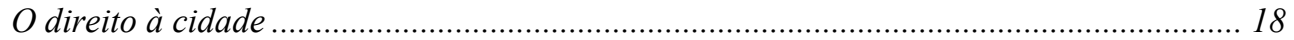

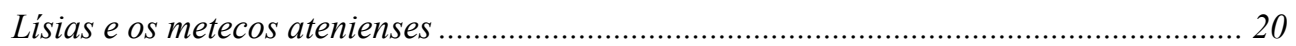

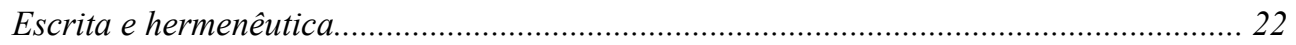

PARTE I: Historiografia

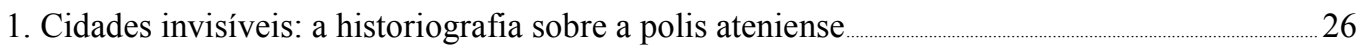

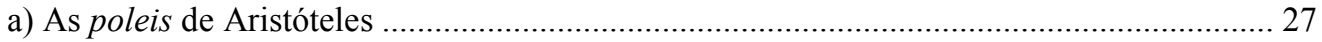

b) Formas e modelos: a comunidade de cidadãos ............................................................... 29

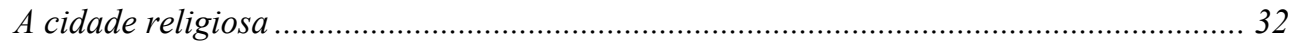

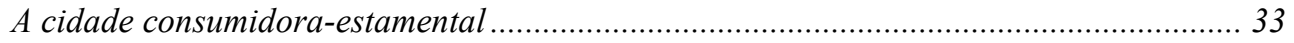

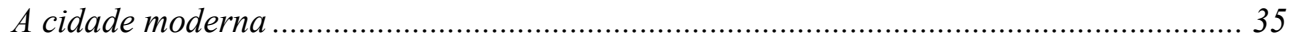

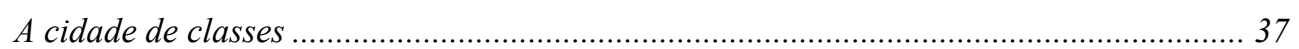

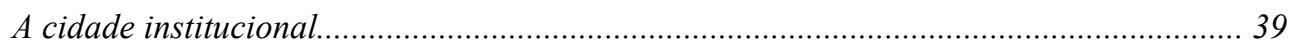

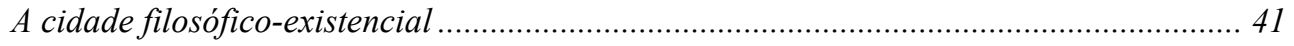

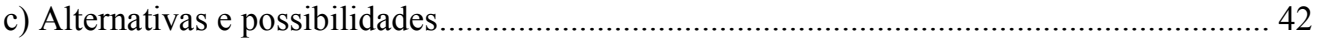

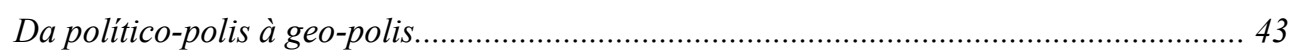

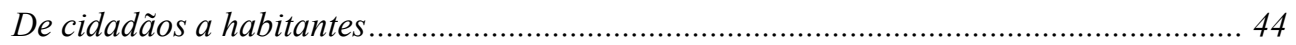

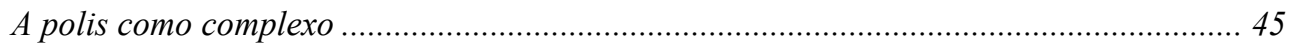

2. Homo oeconomicus: a historiografia sobre os metecos atenienses ……...................................................... 49

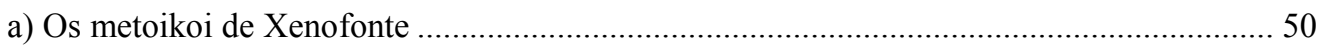

b) Formas e modelos: a reificação da metoikia ............................................................... 52

Os metecos concidadãos de Michel Clerc........................................................................... 56

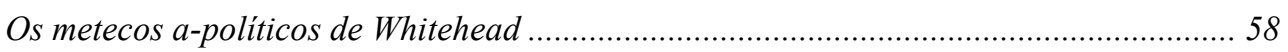

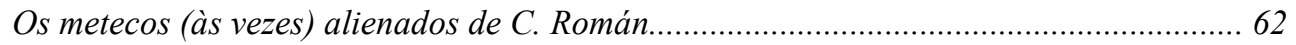

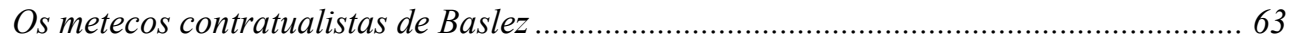

c) $\mathrm{O}$ abandono da liberdade: cidadãos e metecos em Contra Filon ....................................... 65

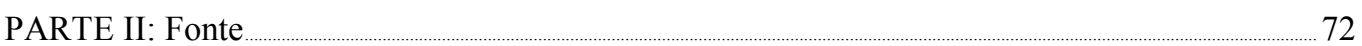

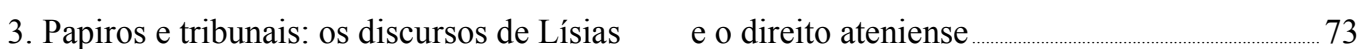

a) Questões sobre o Corpus: Antigos e Modernos ........................................................ 74

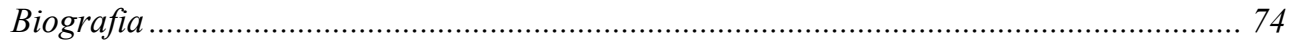

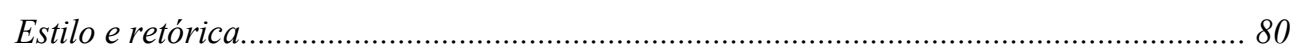




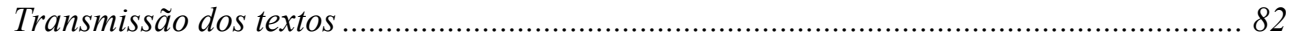

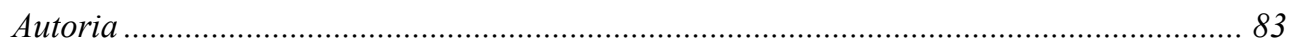

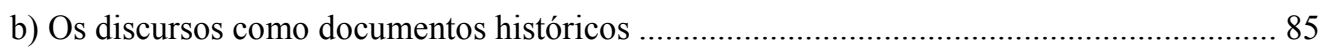

O uso e o abuso dos oradores áticos segundo S. C. Todd................................................. 86

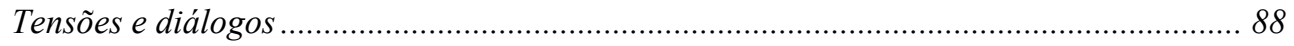

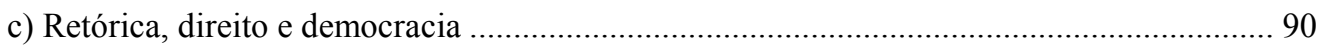

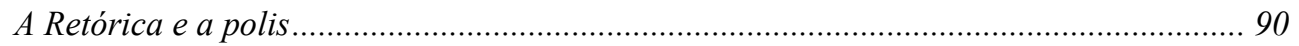

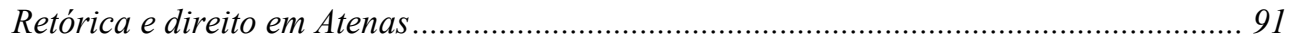

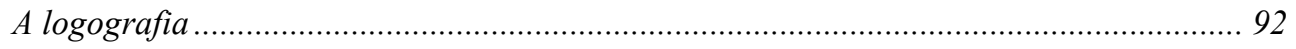

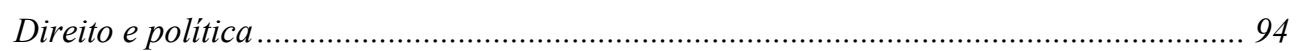

4. Lugares da política: espaço, identidade e memória em Lísias ……............................................................................97

a) Usos políticos do espaço ........................................................................................ 98

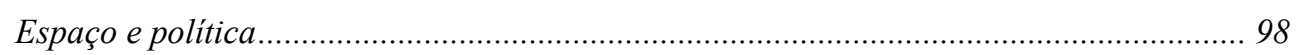

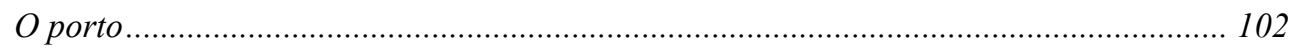

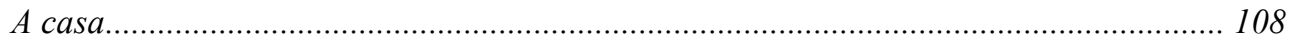

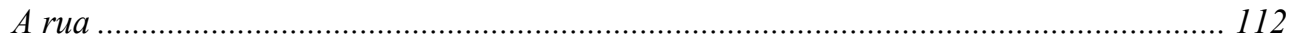

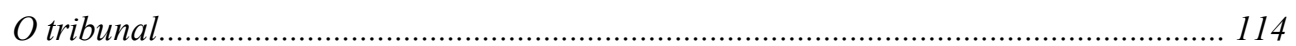

b) Retóricas da identidade e da memória ................................................................... 118

A dialética ser-devir e a política das identidades ......................................................... 119

Identidades ético-políticas atenienses: cidadãos e metecos ........................................... 122

Seria o meteco um “democrata subordinado”? ........................................................... 129

Das políticas da identidade à memória ..................................................................... 131

Usos da memória, entre a democracia e a oligarquia ................................................ 133

A lembrança dos metecos restauradores ................................................................. 140

c) "Por natureza, nem oligarca, nem democrata": memória e teoria política em Defesa a uma acusação de subverter a democracia.

PARTE III: Questões.

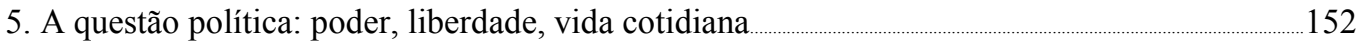

a) As políticas na Política de Aristóteles ....................................................................... 153

b) Do Estado às relações de poder ................................................................................... 158

O papel das instituições segundo M. Hansen ............................................................ 159

Estado e ação política segundo M. Finley ................................................................. 161

Discurso, poder e política segundo J. Ober e M. de Andrade .......................................... 163

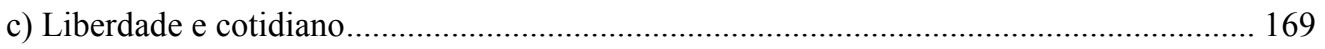

O anfiteatro da liberdade em Hannah Arendt .......................................................... 169

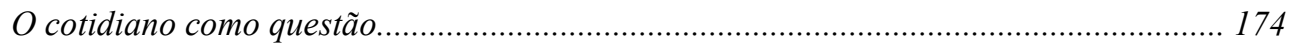

Cotidiano e estilo de vida em Henri Lefebvre e Marta de Andrade .................................. 176

As estruturas do cotidiano em Agnes Heller e Norberto Guarinello ................................ 180 


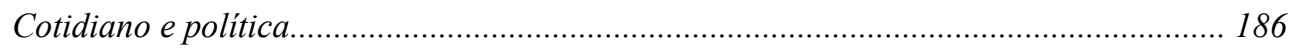

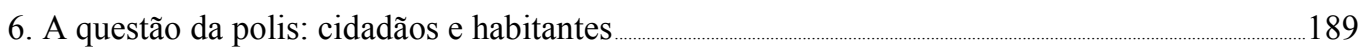

a) A polis como "mediação imediata" .............................................................................. 190

A polis entre o telos e a propriedade: Aristóteles e Marx.............................................. 190

Objetivação e subjetivação da polis-intitucional ............................................................. 194

A primazia da política ................................................................................................. 197

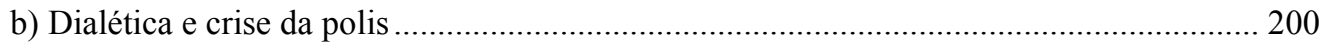

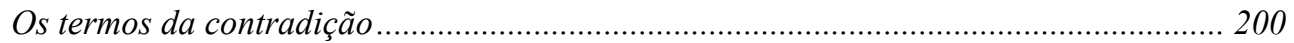

Escravidão e brecha jurídica: Cálias e Pancleão........................................................... 202

Metoikia e brecha jurídica: os mercadores de trigo ....................................................... 206

c) A democracia pelo avesso: cisão e porosidade em Contra Eratóstenes ......................... 208

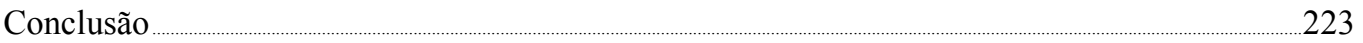

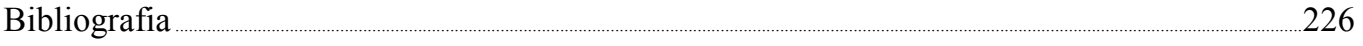

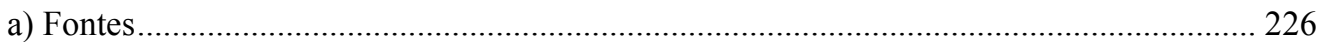

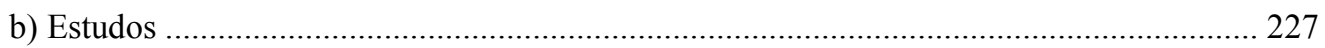




\section{Numeração dos discursos e}

\section{fragmentos do Corpus Lysiacum}

1. Sobre o assassinato de Eratóstenes.

2. Oração Fúnebre.

3. Contra Simon.

4. Sobre uma agressão premeditada.

5. Por Cálias.

6. Contra Andócides.

7. Sobre a oliveira sagrada

8. Contra os membros de uma associação

9. Pelo soldado.

10. Contra Theomnestus (I).

11. Contra Theomnestus (II).

12. Contra Eratóstenes.

13. Contra Agoratos.

14. Contra Alcibíades (I).

15. Contra Alcibíades (II).

16. Por Mantitheus.

17. Sobre a propriedade de Eraton.

18. Sobre a propriedade do irmão de Nícias.

19. Sobre a propriedade de Aristofanes.

20. Por Polístrato.

21. Sobre uma acusação de receber suborno.

22. Contra os mercadores de trigo.

23. Contra Pancleão.
24. Pelo Inválido.

25. Defesa a uma acusação de subverter a democracia.

26. Contra Evandro.

27. Contra Epícrates.

28. Contra Érgocles.

29. Contra Filócrates.

30. Contra Nicômaco.

31. Contra Filon.

32. Contra Diogeiton.

33. Oração Olímpica.

34. Contra uma proposição que visa destruir a constituição ancestral.

35. Erótico.

Frag.1. Contra Ésquines o Socrático.

Frag.2. Contra Teisis.

Frag.3. Por Frínico.

Frag.4. Contra Cinésias.

Frag.5. Contra Archebiades.

Frag.6. Contra os filhos de Hipócrates.

Frag.7. Contra Hippotherses.

Frag.8. Contra Theomnestus.

Frag.9. Por Eryximaco.

Frag.10. Contra Teozotides.

Frag.11. Sobre a filha de Antifonte. 


\section{Introdução}

"Quando nossa consciência histórica se transporta para horizontes históricos, isso não quer dizer que se translade a mundos estranhos que nada têm a ver com o nosso; ao contrário, todos eles juntos formam esse grande horizonte que se move a partir de dentro e que abarca a profundidade histórica de nossa autoconsciência para além das fronteiras do presente. Na realidade, trata-se de um único horizonte que engloba tudo quanto a consciência histórica contém em si. O nosso próprio passado e o dos outros, ao qual se volta a consciência histórica, faz parte do horizonte que a determina como origem e tradição".

- Hans-Georg Gadamer, Verdade e Método (1960) 


\title{
Os Trinta e a restauração
}

Segundo as fontes ${ }^{1}$, o general espartano Lisandro, alguns meses após a vitória decisiva da frota peloponésia sobre os atenienses na batalha de Aigos-Potamos, mediou as negociações de paz entre líderes atenienses, Teramenes em particular, e os éforos espartanos: entre as condições, estavam a demolição das muralhas de Atenas, além da entrega da frota e da aliança militar com Esparta. Selada a paz, o regime democrático foi abolido e um grupo de Trinta cidadãos ficou encarregado, com apoio de Lisandro, de reformar a constituição ateniense no sentido de um retorno à constituição ancestral, o que na prática significava instaurar uma oligarquia. Tendo indicado os quinhentos membros do Conselho, os Trinta construíram um regime que duraria cerca de oito meses, do final de 404 até meados de 403 a. C. Segundo o autor da Constituição de Atenas, os Trinta o início

\begin{abstract}
se mostravam comedidos para com os cidadãos, e pretextavam a administração do regime ancestral. Revogaram do Areópago as leis de Efialtes e de Arquéstrato respeitantes aos areopagitas; revogaram as ordenações de Sólon de caráter controverso [...]. No início, então, tomaram tais medidas e eliminaram não apenas os sicofantas como ainda os elementos prejudiciais que, danosos e vis, viviam a bajular o povo. A cidade regozijava-se com tais medidas, por entender que eles estavam agindo para o bem. Porém, tendo ganho maior domínio sobre a cidade, não pouparam qualquer cidadão, passando, pelo contrário, a executar as pessoas eminentes - seja pela fortuna, seja pelo nascimento, seja pela reputação -, tanto preocupados em suprimir seus temores quanto desejosos de espoliar-lhes os bens. Assim, em pouco tempo, liquidaram não menos de mil e quinhentas pessoas (XXXV, 2-4) 2 .
\end{abstract}

Não se sabe ao certo quanto tempo durou a era de ouro do regime, mas sabe-se que, quando terminou, dois dos principais líderes dos Trinta se opuseram: de um lado, Crítias, que visava um regime com plenos poderes, inclusive o de executar cidadãos que

\footnotetext{
${ }^{1}$ As principais fontes para o regime dos Trinta em Atenas são: Constituição de Atenas, caps. XXXV-XL, de Aristóteles; Helênicas, livro II, de Xenofonte; Contra Eratóstenes, de Lísias; e História Universal, XIV, de Diodoro Sículo. Não serão discutidas aqui as incoerências entre as fontes.

${ }^{2}$ A obra consultada é a edição brasileira (bilíngüe) da Constituição dos Atenienses, feita pela Editora Hucitec, com tradução de Francisco Murari Pires.
} 
a ele se opusessem, e de outro Teramenes, figura central nas negociações de paz com Esparta (que mantiveram a vida dos atenienses, mas sob o custo da derrubada das muralhas e entrega da frota), que defendia uma oligarquia moderada e se opunha às execuções. Diante do aumento do prestígio de Teramenes entre os cidadãos e o Conselho, os Trinta, encabeçados por Crítias, consideraram Teramenes inimigo do regime e o executaram. Depois disso, os Trinta, com apoio da cavalaria, de centenas de hoplitas atenienses e de soldados espartanos que estavam acampados na Acrópole, aumentaram o número de execuções, desarmando e exilando os habitantes de Atenas, cidadãos e metecos, que se mostravam contrários à oligarquia.

Os democratas atenienses banidos pelos Trinta organizaram um exército que, sob o comando de Trasíbulo, tinha como missão a restauração da democracia em Atenas. Partindo principalmente de Tebas e Mégara, o exército democrata reuniu soldados e recursos e, em 403 a. C., realizou a invasão da fortaleza de File, no nordeste da Ática. Após uma inesperada vitória sobre o exército dos Trinta e os soldados da guarnição espartana, o contingente democrata aumentou de algumas dezenas para setecentos e em seguida para mil combatentes. De File, Trasíbulo dirigiu seu exército para Muníquia, colina situada no nordeste do Pireu. Os homens de File, agora homens do Pireu, conquistavam cada vez mais adeptos, aí incluídos escravos e metecos. Uma nova batalha foi travada entre democratas, do Pireu, e oligarcas, da asty: nesta batalha, a vitória dos democratas foi acompanhada da morte de dois membros dos Trinta, entre eles Crítias. Após isso, os membros remanescentes dos Trinta refugiaram-se em Elêusis, enquanto que aqueles que ficaram na asty resolveram criar uma comissão de cidadãos, os "Dez", que deveria mediar a paz entre democratas e oligarcas.

Os remanescentes dos Trinta em Elêusis enviaram embaixadores a Esparta pedindo reforços contra os democratas do Pireu, ao que foram atendidos: o general espartano Lisandro bloqueou a navegação para o Pireu, inviabilizando o abastecimento dos democratas. Pouco tempo depois, um dos reis espartanos, Pausânias, seguiu com aliados para organizar o cerco aos homens do Pireu. Em pouco tempo ocorreria a batalha do Pireu, que se por um lado marcou a derrota do exército de Trasíbulo para as forças espartanas, por outro significou o início concreto do armistício; foi o próprio rei Pausânias quem, após a vitória sobre os democratas, passou a realizar a mediação entre as duas facções na direção do fim da guerra civil. Após as negociações de paz, foram definidos os termos da reconciliação: 
Os atenienses que permaneceram na cidade e que desejarem emigrar habitarão Elêusis, ficando na posse de seus direitos e no gozo de seus rendimentos, e tendo plenos poderes para se governarem soberanamente. O santuário será comum a ambos [...]. Não será permitido nem aos de Elêusis deslocarem-se para a cidade, nem aos da cidade para Elêusis, exceção feita a ambos quando dos Mistérios. Igualmente aos demais atenienses, eles também contribuirão com seus rendimentos para o fundo dos aliados. Caso algum dos emigrados queira ocupar uma propriedade em Elêusis, que ele acerte com o proprietário [...] Eles decidirão quais habitantes de Elêusis conviverão com ele. Os residentes em Atenas dispostos a emigrar terão dez dias para se inscrever e vinte para emigrar, a contar do dia da prestação do juramento; os ausentes terão os mesmos prazos, a partir do dia de seu retorno. [...] Não serão

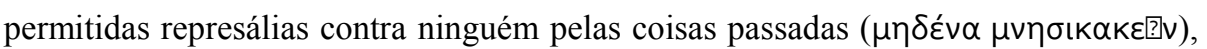
exceto contra os Trinta, os Dez, os Onze e os governantes do Pireu; e nem mesmo contra esses, caso eles apresentem a sua prestação de contas, e os governantes do Pireu prestarão suas contas aos cidadãos do Pireu, e os da cidade aos cidadãos que tiverem declarado seus rendimentos. Mas emigrem os que assim desejarem. Cada uma das facções pagará, separadamente, os empréstimos em dinheiro contraídos para a guerra (XXXIX, 1-6).

Dados os termos da reconciliação, foram feitos os juramentos - em particular o de não lembrar dos males passados, me mnesikakein - e a democracia foi restaurada. Grande número de cidadãos emigrou para Elêusis, que se tornaria uma cidade independente; no entanto, hostilidades se iniciaram entre os de Elêusis e os da cidade, e algum tempo depois (provavelmente 401 a. C.) Elêusis foi reincorporada a Atenas, seus líderes executados e seus cidadãos reintegrados no corpo cívico ateniense - mantendo o juramento de me mnesikakein quanto a estes. Quanto aos que ficaram na cidade, a anistia parece ter sido respeitada, apesar de que a participação nas oligarquias foi transformada em argumento para impedir que certos cidadãos ocupassem cargos públicos.

A democracia ateniense não seria mais abalada por mais de meio século, até o início da dominação macedônica. 
Este trabalho trata da questão dos estrangeiros residentes, metecos ${ }^{3}$, na polis ateniense no final do século V e início do IV a. C. Questão que pode ser ampliada como a questão do outro no mundo dos outros, ou seja, do ser estrangeiro (meteco) no mundo dos estrangeiros (a polis dos atenienses). Esta colocação do problema já indica, de início, a questão da identidade: a identidade do outro, a identidade do mundo dos outros ${ }^{4}$. Identidade do outro que é uma construção de mão-dupla, a saber, da polis que cria um estatuto social determinado, a metoikia, e do estrangeiro residente que vive na polis e negocia sua sociabilidade por meio deste mesmo estatuto, alterando-o portanto; chocam-se assim um movimento de ordenamento (polis) contra um movimento de negociação (meteco), marcando uma contradição do (e que resulta no) processo de identificação do outro. Identidade do mundo dos outros que não é menos contraditória: a identidade da polis ateniense pressupõe sua alteridade, pressupõe o não-ateniense, e, mais específico, o não-cidadão ateniense, seja no plano interno (o estrangeiro residente), seja no plano externo (as outras poleis). Portanto, a questão da alteridade não se separa da questão da identidade, e assim a questão dos metecos atenienses é também a questão da polis dos atenienses. Neste sentido, este trabalho não se coloca como discurso de "inclusão dos excluídos da História" como fim em si, não obstante esta seja uma etapa fundamental; procura-se pensar, dialeticamente, o processo social de inclusão/exclusão que estabelece os vetores tanto da subjetividade dos excluídos quanto da objetividade da exclusão - entre a política sobre os metecos e a política dos metecos. A história dos metecos atenienses é aqui tanto resgate da historicidade destes excluídos quanto análise das bases sociais da estruturalidade da polis: a história dos metecos atenienses não deixa nunca de ser a história da polis ateniense.

Ora, é por conta deste paralelismo (questão dos metecos/questão da polis) que assume importância central a imagem que temos, enquanto sujeitos históricos e sociais, da polis ateniense em particular e da polis em geral: tal imagem condiciona as questões históricas cabíveis na história da polis, e é a partir da crítica desta imagem (e

\footnotetext{
${ }^{3}$ A tradução do termo grego metoikos é bastante discutida. Geralmente entendido como "aquele que mora junto", a palavra deriva de meta, que pode significar "junto de", "que veio de", "posto em"; e oikos, “casa, família, bens privados". Whitehead (1977) defende que o sentido de metoikos incorpora o conceito de mudança, migração.

${ }^{4}$ Derrida (2003), discutindo o tema da hospitalidade a partir da filosofia grega, em especial dos diálogos platônicos, formula a questão da seguinte maneira: a questão do estrangeiro é ao mesmo tempo a questão posta pelo estrangeiro e para o estrangeiro.
} 
conseqüentemente de suas respectivas questões) que se configura possível uma pesquisa sobre os metecos atenienses. Assim, por exemplo, se a imagem da polis ateniense que norteia uma pesquisa histórica é aquela que associa a polis exclusivamente aos seus cidadãos, a questão dos metecos se reduz ao tema da inclusão/exclusão na polis - a dimensão política da sociabilidade dos metecos seria um tema absurdo, estando a política restrita aos cidadãos (exclusivos membros da polis).

No entanto, a história da restauração democrática de 403 a. C., acima mencionada, coloca problemas que vão além da associação polis-cidadãos. Os metecos atenienses, de acordo com as fontes, vão apoiar a restauração, tanto diretamente (fazendo parte do exército democrata) quanto indiretamente (através do financiamento da guerra). Ora, qual é o significado deste apoio? Fariam política os metecos atenienses? E mais: para além dos benefícios prometidos, o que significa o apoio dos metecos a um regime no qual eles estariam excluídos? Qual é a relação dos metecos com a democracia, e quais alterações nesta relação teriam sido operadas pela Tirania dos Trinta? E por fim: o que é política, e o que é polis, considerando o apoio dos metecos à restauração democrática?

\section{Estrangeiros, exclusão e inclusão}

Em 2005, o governo dos Estados Unidos propôs um pacote de medidas antiimigração que incluía a deportação em massa dos imigrantes ilegais presentes no país, cerca de 15 milhões. Protestos de imigrantes (legais e ilegais) foram realizados em grandes cidades, além de críticas de autoridades políticas (relativas inclusive aos gastos com a deportação), o que fez com que a deportação em massa não se concretizasse. No ano seguinte, o partido republicano sofreu uma forte derrota eleitoral, devido em grande parte, segundo analistas, ao peso do "voto hispânico", que associou "partido republicano" a "leis anti-imigração". Mas isso não impediu que, ainda em 2006, fosse aprovada pelo Congresso uma medida relativa à expansão do muro da fronteira EUAMéxico (DÁVILA, 2006; CUNHA, 2006).

Do outro lado do Atlântico, e para além do quadro eleitoral, a França, também em 2005, foi palco de uma série de "revoltas urbanas" no final do mês de outubro e início de novembro, a partir da morte de dois adolescentes de origem imigrante na cidade de Clichy-sous-Bois, na periferia de Paris. Realizados principalmente por jovens 
desempregados ou com subempregos, os protestos promoveram o incêndio de mais de mil automóveis e a explosão de dezenas de edifícios públicos, aparentemente sem coordenação ou liderança; o governo francês buscou a pacificação social essencialmente com a repressão, materializada em toques de recolher, prisões e expulsões coletivas. $\mathrm{O}$ movimento de repressão foi levado a cabo pelo então ministro do Interior, Nicolas Sarkozy, que já havia, em ocasião anterior, caracterizado imigrantes e descendentes como racaille, "escória” (VICTOR, 2005; REIS, 2006).

Novamente do lado de cá do Atlântico, mais ao sul entretanto, um exemplo invertido. No dia primeiro de janeiro de 2007 ocorreu no Brasil a cerimônia de posse do presidente Luiz Inácio Lula da Silva, reeleito. A multinacional Coca-Cola se dispôs a distribuir garrafas confeccionadas especialmente para o evento, contendo uma imagem do Palácio do Planalto e a inscrição "Posse Presidencial - República Federativa do Brasil. Luiz Inácio Lula da Silva, 2007-2010”. No dia anterior, a mesma empresa havia patrocinado uma festa de ano novo em uma mansão em Brasília: entre os 150 convidados, muitos deles "políticos", estavam três ministros da República (Planejamento, Previdência e Turismo). A pedido da empresa, os convidados deveriam trajar roupas de cor branca ou vermelha, ou seja, as cores da mercadoria principal, o refrigerante Coca-Cola. A jornalista Cátia Seabra, que cobriu o evento, notou que o ministro do planejamento Paulo Bernardo, de um partido ligado aos trabalhadores, vestiu vermelho. Justificou-se o ministro: "Como não tinha branco, vesti vermelho. A simbologia aí não é comunista, socialista. É a Coca-Cola mesmo” (SEABRA, 2007).

As migrações populacionais contemporâneas, assim como as migrações de capitais, respondem a imperativos que escapam em grande medida da vontade individual dos sujeitos (tanto do migrante quanto do capitalista). Ainda que a recepção dos locais de destino seja extremamente diferente quanto à natureza do migrante (trabalhadores ou investimentos), ambas as migrações se realizam de acordo com a lógica da reprodução do capital. O desemprego real e o emprego possível de um lado, as taxas de lucro de outro, se apresentam para os sujeitos como realidades dadas, respondendo a leis "naturalmente" estabelecidas, configurando aquilo que Marx denominou "fetichismo", ou seja, o fato de produtos da ação social adquirirem vida 
própria e se regerem como que independentemente da ação social: como Marx desenvolve nos três livros d'O Capital, o fetichismo se apresenta não só na mercadoria, como também no dinheiro ou mesmo nas leis econômicas e médias sociais - estas "coisas com vida própria" não são meras aparências ou enganos, mas realidades efetivas: são "ilusões reais", até porque a consciência deste fenômeno "não dissipa, de modo algum, a aparência objetiva das características sociais do trabalho" (MARX, 1988, p. 72).

O fetichismo, que não se separa de outros conceitos formulados na tradição marxista, como os de reificação e alienação, ao mesmo tempo em que movimenta o sistema como um todo, se apresenta ao sujeito, enquanto imposição, na dimensão cotidiana da vida social: trabalhar, deslocar-se, trocar mercadorias, consumir. Daí se falar em um cotidiano reificado, alienado, e, especialmente no contexto do consumo de massa dirigido, em um cotidiano colonizado (DEBORD, 1961). Mas, se a reprodução das relações sociais capitalistas se dá nos marcos do cotidiano, no cotidiano também são reproduzidas suas contradições internas, abrindo espaço portanto para sua negação (LEFEBVRE, 1961; HELLER, 1982).

Os três exemplos acima (EUA, França, Brasil) tratam de estrangeiros residentes, trabalhadores ou empresas. Os dois primeiros apontam para esta negação do cotidiano como alienação: as passeatas nos EUA e os incêndios na França podem ser lidos como explosões de movimentos de negação dentro do quadro da contradição entre inclusão na esfera da produção e exclusão da esfera do consumo e da política (Martins, 1997). No terceiro exemplo, o cotidiano é flagrado como momento da reprodução do capital (relações empresa-Estado, privado-público, capital-política), e neste movimento se torna explícito o processo mais geral. Mas em que medida a vida cotidiana é reprodução e simultaneamente negação das relações sociais capitalistas? Como estes movimentos contraditórios do cotidiano se apresentam no cotidiano? Como pensar a liberdade como realidade cotidiana?

\section{$O$ direito à cidade}

Na cidade de São Paulo do início do segundo milênio, a construção de um novo empreendimento imobiliário às margens do rio Pinheiros (fusão de condomínio fechado, clube, shopping e centro de escritórios) produz três fragmentos da vida urbana: 
Fragmento 1: Texto no site do empreendimento "Parque Cidade Jardim ",

"Com ruas arborizadas e exclusivamente residenciais, a Cidade Jardim tem a natureza como um de seus principais atrativos. Suas árvores, praças e parques são uma importante reserva da Mata Atlântica. [...] Morar no Cidade Jardim é ter uma vida tranqüila em equilíbrio com as facilidades de uma grande metrópole. O bairro reúne à sua volta as melhores escolas, hospitais, o Jockey Club, e fica próximo das principais avenidas da cidade, como a Faria Lima e a Cidade Jardim. Um lugar nobre em São Paulo, porque, além da concentração de áreas verdes, também tem a maior renda per capta do Brasil. O padrão de vida é semelhante aos mais altos do mundo. A Cidade Jardim realmente é muito especial, um lugar bonito, charmoso, perto de tudo de bom que a cidade oferece".

\section{Fragmento 2: Manifesto dos moradores da favela "Jardim Panorama",}

“Aproveitamos este MOMENTO DE FESTA, no dia 24 de maio de 2006, junto ao lançamento oficial do Parque Cidade Jardim, para expressar e esclarecer a opinião da comunidade da Favela Jardim Panorama sobre sua situação atual. [...] Conhecendo histórias de desapropriação de favelas para a construção de grandes empreendimentos imobiliários e viários, como foi e continua sendo a história do Jardim Edith, do outro lado da Marginal Pinheiros, nós, moradores da Favela Jardim Panorama, localizada do bairro do Morumbi, fazemos este manifesto para DIZER PARA A SOCIEDADE E PARA NOSSOS NOVOS VIZINHOS que somos seres humanos e cidadãos e SABEMOS DOS NOSSOS DIREITOS e vamos lutar para adquirir: urbanização, moradia digna e emprego. [...] Reivindicamos apenas a PRÁTICA de uma cidade justa, DE DIREITOS IGUAIS A TODOS!”

Fragmento 3: Matéria do site O Globo Online de 12/09/2007.

“Os proprietários de um dos maiores complexos de luxo de São Paulo, o Parque Cidade Jardim, que reunirá shopping e condomínio residencial, na Marginal Pinheiros, estão pagando R\$ 40 mil para os moradores da favela Jardim Panorama, saírem de suas casas, vizinhas ao empreendimento. Pelo menos 70 famílias já deixaram o terreno. (...) O total pago pela construtora às famílias é oito vezes maior do que o valor que a Prefeitura paga para retirar famílias de terrenos públicos - R\$ 5 mil”.

A trama das relações entre o "empreendimento Parque Cidade Jardim" e a favela "Jardim Panorama" escancara a complexidade do fenômeno urbano atual, por meio da multiplicidade dos espaços, tempos, ritmos e níveis da realidade social. A constituição simbólica de um enclave de gentrificação por cima de uma favela; a materialização de um discurso virtual na forma de práticas de expulsão, gerando a contrapartida de um discurso dos expulsos materializado em panfletos; as temporalidades do movimento do

\footnotetext{
${ }^{5}$ Fonte: $<$ http://www.parquecidadejardim.com.br>, consultado em maio de 2007.

${ }^{6}$ Fonte: $<$ http://www.midiaindeendente.org $>$, consultado em maio de 2007.
} 
capital imobiliário e da habitação popular, formando uma tríade contraditória com a ação estatal; a oposição, mais fundamental, entre economia e sociedade, fetichismo do capital e cidadania dos moradores - o que é, afinal, a cidade? Espaço de apropriação ou espaço de alienação? Espaço ou representação de um espaço futuro já valorizado?

As contradições da metrópole de São Paulo, metrópole periférica em relação à economia global e ao mesmo tempo atravessada por diversas outras centralidades/perifericidades, seria um caminho de análise adequado para a questão urbana atual? A "cidade" de São Paulo é um bom parâmetro para se pensar as cidades brasileiras, do hemisfério sul, do globo? Ora, toma-se a polis ("cidade"? "cidadeEstado"?) de Atenas como parâmetro - mas parâmetro do quê? Das poleis jônias, gregas, clássicas, mediterrânicas?

E mais, tomando a cidade contemporânea em suas contradições, ainda é possível uma tradução do termo grego polis por "cidade"? Haverá ainda, para além de trajetórias filológicas, alguma ligação semântica possível entre a polis e a "cidade" atual? Seria o espaço da polis atravessado por tensões, politizado por regulações e usos como é o espaço urbano contemporâneo?

\section{Lísias e os metecos atenienses}

No período de radicalização da oligarquia dos Trinta, os metecos atenienses, especialmente os mais ricos, foram escolhidos como alvos das perseguições - a acreditar em Lísias, meteco ateniense que relata, em seu discurso Contra Eratóstenes, sua própria história de perseguição. Filho do fabricante de armas Céfalo e provavelmente nascido em Atenas, logógrafo e professor de retórica, Lísias, já coma democracia restaurada em 403 a. C., escreve (e segundo a tradição pronuncia no tribunal) o discurso Contra Eratóstenes, no qual acusa um dos tiranos pelo assassinato de seu irmão, Polemarco. Segundo Lísias as coisas teriam se passado da seguinte maneira: sem dinheiro, os Trinta resolveram confiscar os bens de alguns metecos ricos, entre eles Lísias e Polemarco, que se opunham ao regime; um dos Trinta, Peison, invadiu a casa de Lísias, o prendeu e o levou à casa de um cidadão que apoiava a oligarquia, Damnipus; como Lísias já havia freqüentado a casa de Damnipus, conhecia diversas saídas, o que the permitiu escapar de Peison e fugir de Atenas. Seu irmão Polemarco não teve a mesma sorte: enquanto Peison prendia Lísias, outro tirano 
membro dos Trinta, Eratóstenes, foi à procura de Polemarco, encontrando-o no caminho. Preso, Polemarco foi condenado a beber cicuta; nenhuma honra fúnebre lhe foi permitida. Após a narrativa, o orador afirma, enfático:

Não merecíamos da polis semelhante tratamento; tínhamos custeado todas as apresentações de coros (choregias), pagamos muitas contribuições militares (eisforai), nos mostramos ordeiros (kosmious) e cumprimos com tudo o que nos foi requerido; não fizemos inimizades e resgatamos muitos atenienses do inimigo. E assim eles nos recompensaram, não sendo metecos como eles foram cidadãos! Eles, que exilaram tantos cidadãos para o meio dos inimigos; que negaram sepultura a tantas vítimas de seus crimes; que privaram tantos cidadãos de seus direitos! (12.20-23).

"Os metecos atenienses estão excluídos da política" é uma frase comum na historiografia. Mas o que afinal ela significa? Pressupõe-se, de início, noções de política e de exclusão que são, ademais, raramente definidas. E mais que isso, parte-se do ponto de vista dos cidadãos: os metecos estão excluídos da política pela ação institucional da polis, que os exclui para reconhecer-se enquanto tal, ou seja, exclusiva dos cidadãos. Este trabalho propõe o caminho inverso, ou seja, o de pensar a exclusão e a política a partir de um ponto de vista meteco, por meio da análise do chamado Corpus Lysiacum, que compreende uma série de discursos atribuídos a Lísias (integrais e fragmentários) que foram preservados ao longo dos séculos.

Este deslocamento analítico permite uma visão da sociedade ateniense - esta é a hipótese - para além tanto dos discursos dos cidadãos atenienses quanto da própria historiografia, possibilitando uma rediscussão do conceito de polis. É possível pensar uma história da polis que inclua a história dos não-cidadãos, ou esta última estaria fadada a permanecer como apêndice em manuais? É possível pensar a história da polis sem a história dos não-cidadãos, em sua especificidade e nas suas relações com a polis? E mais: se limitariam os metecos às funções a eles atribuídas pela polis? Seriam os metecos puramente homines oeconomici? Estas questões são os eixos da primeira parte da dissertação, composta por uma discussão das historiografias sobre a polis (capítulo 1) e sobre os metecos atenienses (capítulo 2).

Feitas as discussões historiográficas, toma o lugar a análise dos próprios discursos, base da segunda parte da dissertação. Entretanto, o Corpus atribuído a Lísias 
possui diversas questões específicas: a composição e ordenamento dos discursos, as dúvidas sobre autoria e autenticidade, as possibilidades de leitura histórica dos discursos e a própria inserção dos discursos no sistema judiciário ateniense (capítulo 3). Em seguida, uma série de discursos é analisada a partir de três temas principais: as representações do espaço, a construção de identidades e a produção da memória (capítulo 4).

Após a imersão na fonte, a atenção se volta para a construção do conceito de política implícito tanto na análise da historiografia quanto da fonte. Esta construção se apóia na discussão de alguns autores que abordaram o tema, autores estes especialistas ou não na história ateniense. Longe de um esquema cronológico da construção acadêmica do conceito, a discussão está estruturada logicamente: o conceito de política migra do Estado para a liberdade, e desta para a vida cotidiana (capítulo 5). Em seguida, a questão primordial é reposta: o que é a polis? Não se pretende, obviamente, fechar a questão; trata-se, muito mais, de realizar um exercício de deslocamento do foco, dos cidadãos aos habitantes, pensando as contradições presentes no processo de (re)produção da polis (capítulo 6).

\section{Escrita e hermenêutica}

A escrita da dissertação ocorreu em momentos distintos: as diferenças de intensidade, de maturidade intelectual e de filiação teórica (marxista, foucaultiana, ricoeuriana, lefebvriana, arendtiana, "norbertiana" etc) são os indícios da temporalidade da escrita. Quando à apresentação e leitura dos discursos, o método se distancia de análises estatísticas de ocorrências desse ou daquele termo, desse ou daquele argumento: mais importante é o modo pelo qual determinado discurso pode apresentar novas questões para as problemáticas desenvolvidas. Tentou-se "desviar" os discursos, fazê-los dizer o que não se propunham a dizer, inseri-los em problemáticas estranhas à sua produção para ao mesmo tempo estranhar estas problemáticas no choque com os discursos. Por isso, esta dissertação não apresenta a estrutura habitual "pressupostos teóricos/estudo de caso": os pressupostos teóricos não deixam de ser "pré" depois do estudo de caso, na medida em que o "caso" não se submete aos pressupostos, pelo contrário, os redefine e os desvia a cada aproximação. Em toda a dissertação está a questão da política, formulada e reformulada a cada passo, e, se é definida em 
determinada passagem, trata-se apenas de uma de(fin)ição precária e provisória dentro do processo do questionamento. De um ponto de vista geral, este processo se fundamentou em três diálogos: com o presente, com a historiografia da polis dos séculos XIX e XX, e com as fontes atenienses.

1. Com o presente, por dois caminhos: pela questão do estrangeiro e pela questão da cidade. Da mesma forma em que o desenvolvimento do capitalismo no século XIX motivou grandes debates a respeito da economia antiga e que tais debates colocaram questões ao conhecimento do próprio capitalismo, as "subjetividades explosivas" da questão dos imigrantes hoje tornam possível uma nova compreensão da subjetividade do estrangeiro na Grécia Antiga (marcadas as semelhanças e diferenças), e esta compreensão propõe um retorno à questão atual com novos questionamentos. Além disso, a tradução da palavra grega polis como "cidade" ou "cidade-estado" nos remete à própria questão da cidade: o que é a cidade, ou quais os significados que a cidade adquire no tempo e no espaço, e quais elementos que permitem uma ponte entre o termo polis e a categoria contemporânea de "cidade"? A tradução de polis como cidade não é um pressuposto teórico, mas faz parte de uma pré-compreensão da polis a ser verificada, colocando em questão, a cada passo, o conceito de polis antigo com o conceito contemporâneo de "cidade".

2. Com a historiografia da polis dos séculos XIX e XX, pois este texto se insere nesta tradição ao mesmo tempo em que busca o distanciamento necessário tanto para compreensão (e questionamento) desta tradição quanto para a sua (re)produção crítica. Assim, o questionamento da identificação polis-cidadãos como pressuposto de pesquisa aponta novas possibilidades da continuidade da tradição, que foram negadas ou não desenvolvidas por conta nem tanto da limitação dos documentos quanto pelas teorias e métodos que norteavam os modelos de polis elaborados nos séculos XIX e $\mathrm{XX}^{7}$.

3. Com as fontes atenienses, na tentativa de ir além da dicotomia modernismo/primitivismo por meio de uma dialética entre identidade/alteridade, no sentido de um resgate dos momentos significativos que permitam uma nova fundamentação do próprio diálogo com o passado. Neste sentido, aqui se propõe uma

\footnotetext{
${ }^{7}$ Não é o caso, portanto, de fundamentar a crítica e a renovação historiográfica em termos de "mudança de paradigmas devido ao aumento dos dados inexplicáveis" (Ober, 1996, p. 17), mas de um movimento entre a "complexidade da realidade social" e as transformações dos "interesses sociais envolvidos na produção científica da memória coletiva" (Guarinello, 2003).
} 
leitura dos textos do Corpus Lysiacum que ultrapasse a mera coleta imediata de informações sobre o passado (o texto como prova), mas busque indícios da sociabilidade dos metecos na própria produção social dos discursos, e como estes discursos se reproduzem e se deformam em sua circulação social - é sobre este desvio que se debruça a leitura proposta.

Subjacente a estes três movimentos, está o princípio da crítica de si como um e pelo Outro (Ricoeur, 1991) como pressuposto do conhecimento, rompendo com qualquer pretensão de objetividade pura e isenta de questionamento; trata-se, portanto, de impedir a petrificação e conseqüente fetichização do discurso histórico. 


\section{PARTE I:}

\section{Historiografia}

- De agora em diante, começarei a descrever as cidades - dissera Khan. - Nas suas viagens, você verificará se elas existem.

Mas as cidades visitadas por Marco Polo eram sempre diferentes das imaginadas pelo imperador.

- Entretanto, construí na minha mente um modelo de cidade do qual extrair todas as cidades possiveis - disse Kublai. - Ele contém tudo o que vai de acordo com as normas. Uma vez que as cidades que existem se afastam da norma em diferentes graus, basta prever as exceções à regra e calcular as combinações mais prováveis.

- Eu também imaginei um modelo de cidade do qual extraio todas as outras - respondeu Marco. - É uma cidade feita só de exceções, impedimentos, contradições, incongruências, contra-sensos. Se uma cidade assim é o que há de mais improvável, diminuindo o número dos elementos anormais aumenta a probabilidade de que a cidade realmente exista. Portanto, basta subtrair as exceções ao meu modelo e em qualquer direção que eu vá sempre me encontrarei diante de uma cidade que, apesar de sempre por causa das exceções, existe. Mas não posso conduzir a minha operação além de um certo limite: obteria cidade verossímeis demais para serem verdadeiras.

Ítalo Calvino, Cidade Invisíveis. 
1. Cidades invisíveis:

a historiografia sobre a polis ateniense 


\section{a) As poleis de Aristóteles}

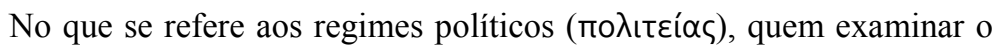
que eles são e quais os atributos de cada qual, a primeira questão a colocar,

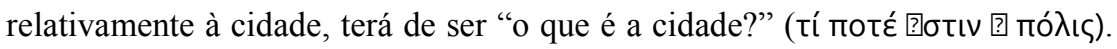
Em primeiro lugar, a natureza da cidade é, hoje em dia, uma questão disputada. Enquanto uns afirmam que foi a cidade que praticou este ou aquele ato, outros afirmam que não foi a cidade, mas sim a oligarquia ou o tirano. Por outro lado, vemos que toda a atividade do político e do legislador está obviamente relacionada com a cidade. Em suma, um regime pol'tico resulta de um certo modo de ordenar os habitantes da cidade. A cidade é, pois, uma realidade composta, da mesma maneira que o são todas as outras coisas que, não obstante possuírem diferentes partes, formam um todo composto. Torna-se evidente, portanto, que devemos começar por orientar nosso estudo para o cidadão, visto que uma cidade é, por assim dizer, uma multidão de cidadãos (?

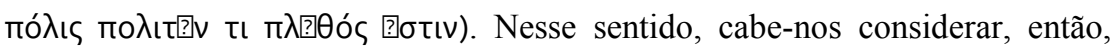
quem deveria ser chamado de cidadão, e o que é um cidadão. (Aristóteles, Política, 1275a $)^{8}$.

Que é uma cidade? Esta pergunta, se feita hoje, não traria menos dificuldades do que as enfrentadas por Aristóteles (cf. Meneses, 1996). De todo modo, a caracterização desta questão como "controvertida" pelo autor da Política indica tanto a polissemia do termo, quanto a inserção da obra dentro de um debate já estabelecido, formando o que viria a ser a "teoria política" como estudo da "natureza do governo". Dentro deste debate, algumas definições são formuladas, conforme Aristóteles menciona: a polis como "sujeito" de uma ação; a polis como "objeto" da ação do estadista ou legislador; a polis como espaço de moradia de habitantes organizados de acordo com uma constituição; a polis categoria de análise (um todo formado por partes); a polis como uma multidão de cidadãos. Tais definições não são necessariamente excludentes, mas

\footnotetext{
${ }^{8}$ A obra consultada é a edição portuguesa (bilíngüe) da Política, feita pela Editora Vega, com tradução de António Campelo Amaral e Carlos Gomes; quando necessário, algumas alterações são feitas com base no original grego: p.ex., o termo $\pi \lambda$ ?]Өó, na citação acima, é traduzido por “composto", quando parece que multidão (de cidadãos) é uma tradução mais adequada.
} 
Aristóteles privilegia as duas últimas, assumindo assim como procedimento imediato a análise do cidadão.

Mas e os não-cidadãos? A “polis dos habitantes" indicada, ainda que não aceita pelo autor, coloca a possibilidade de se pensar a polis para além da multidão de cidadãos, situando o conceito de polis justamente dentro do movimento de relações sociais entre habitantes, cidadãos e não-cidadãos. Além disso, a "polis como sujeito" e a "polis como objeto" nos trazem questões como a relação entre Estado e sociedade em Atenas e da polis como obra social: qual é a natureza da polis que a permite conjugar aspectos subjetivos e objetivos? Quem faz parte, afinal, da polis?

Em vários momentos, Aristóteles nos dá indicações de uma polis para além da multidão de cidadãos. No início do livro 1, por exemplo, a polis é um conjunto de povoados formados por diversas casas, nas quais se entrecruzam as relações senhor/escravo e homem/mulher (1252a-1253a). Isto significa que a mulher e o escravo, não-cidadãos, também são a polis? Sim e não. Sim, pois eles representam as condições de existência da polis (reprodução e trabalho). Não, se tomarmos a separação aristotélica entre "partes" e "condições": são condições da polis aqueles (livres ou escravos) que trabalham para suprir as necessidades da comunidade, enquanto que são parte da polis aqueles que são livres o suficiente para se dedicar à guerra e à política - a polis ideal seria aquela na qual o monopólio das propriedades fundiárias estivesse nas mãos destes últimos, enquanto que os agricultores devessem ser "escravos ou servos bárbaros" (1329a). De todo modo, a projeção desta utopia, muito próxima da imagem que se construiu em Atenas em relação ao modelo espartano (MOSSÉ, 1986), pode significar um indício de que o "fazer parte da polis" não era um ponto pacífico na Atenas do século IV a. C., mas pelo contrário estava imerso nas relações sociais que (re)produziam a própria polis, como uma questão social.

Vemos, portanto, que a discussão aristotélica sobre a polis e mesmo sua restrição à "multidão de cidadãos", longe de fechar o conceito de polis como idêntica aos cidadãos, vai na direção de abrir possibilidades para o estudo da polis que leve em conta as relações sociais entre os habitantes. Assim, as três primeiras definições mencionadas acima (polis como sujeito, polis como objeto, e polis como espaço dos habitantes) podem recolocar de um modo diferente a quarta definição, da polis como "um todo formado por partes", ou seja, pensar a polis como um todo marcado por contradições entre partes não-homogêneas, como entre proprietários/não-proprietários, 
livres/escravos, homens/mulheres, nativos/estrangeiros ${ }^{9}$. O estudo do modo de articulação destas contradições dentro da polis permitiria, inclusive, repensar o conceito de política e de cidadania na Atenas Clássica, para além da "multidão de cidadãos".

\section{b) Formas e modelos: a comunidade de cidadãos}

A ênfase na categoria de "polis", traduzida como "cidade" ou "cidade-estado"10, tem sido uma constante na "História da Grécia", enquanto disciplina científica, desde a segunda metade do século XIX e em todo o século XX, a ponto de a "historia grega" ser associada quase que exclusivamente a uma "história das poleis gregas". Mas o que significa, na historiografia moderna, o termo polis? As respostas são variadas: uma cidade de consumidores (com ou sem a separação campo-cidade), uma comunidade sagrada, uma instituição estatal, uma experiência existencial, uma sociedade liberal, uma vila escravista, uma união de aldeias etc. No entanto, existem semelhanças entre os vários "modelos de polis" elaborados pela historiografia dos séculos XIX e XX: em primeiro lugar, o não questionamento da forma "História da Grécia" ou da "História Antiga", ou ao menos uma ausência do enfrentamento teórico de suas contradições; em segundo lugar, a identificação da poleis com a comunidade de cidadãos, os polites, que são definidos de modo estático: homens, adultos, livres e filhos de pais atenienses. Vejamos estas duas semelhanças com mais detalhe.

A "História da Grécia", um dos elementos da tripartição da "História Antiga" (junto com o "Oriente Próximo" e "Roma"), confere coerência a um grande corpo documental oriundo tanto da tradição literária clássica quanto das pesquisas arqueológicas, constituindo-se naquilo que N. Guarinello define como "forma", um conjunto de generalizações ou contextos que fundamentam o "jogo interpretativo entre

\footnotetext{
${ }^{9}$ Não se trata de localizar a estratificação social ateniense sob o ponto de vista exclusivo da "classe", como faz Ste. Croix (1981), ou do "espectro de status", como faz Finley (1986), mas desvendar as lógicas específicas que atravessam os grupos sociais atenienses em suas relações com a institucionalidade e a cotidianidade da polis.

${ }^{10}$ As traduções em inglês, francês e italiano ultrapassam a ambigüidade do termo "cidade" em português, marcando uma oposição entre o aspecto político-institucional e o aspecto espacial e urbano da cidade: em inglês, city se opõe a town, em francês cité a ville, em italiano città a villa (HANSEN, 1998, p. 15).
} 
certos modelos e teorias e certos documentos" (GUARINELLO, 2003, p. 45). Entretanto, a forma "História da Grécia" não é livre de contradições, fundadas tanto na diversidade dos documentos quanto nas questões específicas do tempo e do espaço dos historiadores que a formularam e a reproduzem. A questão da unidade da forma deixa de ser um pressuposto, para tornar-se um problema:

O que dá unidade à história grega? Não é uma história de um país específico ou de um território, já que "gregos se espalharam por toda bacia do Mediterrâneo e além". Seria um idioma comum, ou uma cultura comum, ou uma religião compartilhada? Mas, recentes estudos mostram que a formação de uma identidade grega foi um longo processo, que assumiu diferentes sentidos ao longo dos séculos. Nunca correspondeu a uma sociedade uniforme, a uma mesma cultura ou a um Estado unificado. Além disso, nunca se tornou uma identidade precisa. Atenas e Esparta, para citar os exemplos clássicos, eram ambas cidades gregas, mas social e culturalmente muito diferentes. E o que dizer sobre os tessálios, os epirotas, os arcádios, os macedônios, os gregos do Mar Negro, os gregos sob o Império Romano? De que trata uma História da Grécia Antiga? Qual é seu objeto específico, no espaço e no tempo? Quais são os parâmetros para se definir uma História da Grécia?

Esta forma, na prática e tal como empregada cotidianamente, reúne alguns parâmetros vagamente culturais a um parâmetro político que é claramente dominante. $\mathrm{O}$ que é denominado História da Grécia normalmente é apenas a História de algumas cidades-estados enquanto permaneceram independentes. Uma História que começa com Homero e vai até Alexandre ou, quando muito, até a conquista romana. Em livros didáticos e manuais, tende a ser essencialmente uma História de Atenas e Esparta, precisamente as duas cidades menos típicas que poderíamos pensar como fazendo parte do mundo grego. (GUARINELLO, 2003, p. 53).

Muitos estudos têm contribuído para a crítica da História da Grécia restrita às poleis, especialmente os relacionados à formação da identidade grega e às formas de sociedade diferentes da polis aristotélica, como tribos, confederações e poleis dependentes ${ }^{11}$; além disso, algumas propostas de superação da "forma" História da Grécia têm surgido, fundadas seja na idéia de uma História das "Culturas de CidadeEstado" (Hansen, 2000), que uniria desde cidades mesopotâmicas até gregas e

\footnotetext{
${ }^{11}$ Uma obra fundamental neste sentido é a Alternatives to Athens: varieties of political organization and Community in Ancient Greece, organizada por R. Brock e S. Hodkinson (2000). Também importantes são os artigos publicados nas coletâneas do Copenhagen Polis Centre, entre os quais Demand (1996), Roy (1996) e Hansen (1995 e 1997b), além do estudo sobre a identidade étnica grega de J. Hall (2000).
} 
mexicanas na mesma forma, seja em uma História do Mediterrâneo, cuja unidade conceitual estaria no plano sócio-ecológico (HORDEN;PURCELL, 2000) ou em processos de integração (GUARINELLO, 2003, p. 58). De todo modo, a forma "História da Grécia" como história das poleis (e somente de duas delas) tem perdido cada vez mais seus fundamentos conceituais.

Quanto à segunda semelhança entre os vários modelos de história da polis "grega" (agora já restrita à "exceção típica", Atenas), a saber, a identificação poliscomunidade de cidadãos, observa-se o apagamento da história dos não-cidadãos que habitavam a polis (mulheres, estrangeiros residentes e escravos): se nos manuais os nãocidadãos ocupam apenas os parágrafos finais dos capítulos referentes à sociedade ou população ateniense, na historiografia especializada os não-cidadãos são "excluídos" da História da polis de acordo com a variação das teorias e modelos que informam as pesquisas. O presente estudo busca realizar uma crítica da identificação polis-cidadãos e apresentar uma proposta para um conceito de polis que dê conta das relações sociais entre os habitantes da polis, cidadãos e não-cidadãos. Para isso, inicialmente, serão analisados os principais modelos de polis elaborados no final do século XIX e no século $\mathrm{XX}$, além de um levantamento crítico das propostas alternativas a tais modelos; o foco da análise será a questão da exclusão/inclusão dos não-cidadãos dentro tanto da polis ateniense quanto da "História" da polis ateniense.

Os modelos propostos não correspondem sempre a projetos conscientes dos autores agrupados: trata-se, muito mais, de elementos característicos em cada obra que permitem a identificação de certas semelhanças, sem que necessariamente tenham existido ligações intelectuais ou nacionais entre os autores. Além disso, é uma tentativa de superar as dicotomias econômicas entre primitivistas e modernistas (Will, 1954; Manville, 1994) ou sociológicas entre durkheimianos e weberianos (Murray, 1991), posto que a multiplicidade da historiografia vai além destas oposições. Os critérios adotados para a definição dos modelos serão especialmente a lógica de apresentação da história da polis e quais aspectos são enfatizados e quais são negligenciados como núcleos explicativos, de acordo com as teorias que os informam; elementos secundários de certos modelos podem estar presentes em outros, mas o esforço se concentrará em definir o elemento determinante em cada modelo.

Serão aqui propostos seis modelos de polis, ou seguindo a tradição, seis modelos de "cidade", pelos quais a historiografia pensou a questão dos metecos atenienses, 
analisados a partir das obras de seus principais autores: a cidade religiosa de Fustel de Coulanges e F. de Polignac; a cidade consumidora-estamental de M. Weber e M. Finley; a cidade moderna de E. Meyer, M. Rostovtzeff, E. Cohen e K. Vlassopoulos; a cidade de classes de S. Utchenko, G. de Ste. Croix e E. Wood; a cidade institucional de G. Glotz e M. Hansen; e a cidade filosófico-existencial de J.-P. Vernant e C. Meier.

\section{A cidade religiosa}

Neste modelo, a religião é núcleo do esquema explicativo: a polis é acima de tudo uma comunidade de culto. O fundador do modelo é Fustel de Coulanges, que, na sua clássica A Cidade Antiga, de 1863, se inseria nos debates sociais e políticos do XIX afirmando que, diferentemente dos modernos (cuja sociedade se fundava no trabalho e na liberdade individual), entre os antigos a propriedade privada tinha origem no culto familiar e a liberdade individual era suprimida diante da onipotência do Estado. $\mathrm{O}$ modelo ganhou novo impulso com o estudo do também historiador francês F. de Polignac La naissance de la cité grecque, de 1984, que, inserido na revolução epistemológica que ocorria no campo da arqueologia, analisa o nascimento da polis por meio da instituição de santuários rurais e urbanos e cultos específicos, que, representando os limites entre natureza/cultura e eu/outro, realizariam a definição do território e a identidade cívica da polis.

Qual seria o lugar do estrangeiro residente na cidade religiosa? Se a cidade é o espaço sagrado dos cidadãos, ao estrangeiro cabe o papel de sacrílego. Nas palavras de Fustel de Coulanges:

"O estrangeiro é aquele que não tem acesso ao culto, a quem os deuses da cidade não protegem e que nem sequer possui o direito de invocá-los. Estes deuses nacionais, como só querem receber orações e oferendas do cidadão, repelem todo homem estrangeiro: a entrada do estrangeiro nos templos não é permitida e sua presença durante as cerimônias é um sacrilégio. [...] Desta forma, a religião abria entre o cidadão e o estrangeiro uma distinção profunda e indelével" (FUSTEL DE COULANGES, 1995: 204-5).

Na obra de F. de Polignac, o estrangeiro residente aparece somente com a colonização, na forma de população conquistada: os sujeitos históricos são os 
fundadores, da cidade e dos cultos; os não-cidadãos são meros objetos diante da ação colonizadora, aparecendo na forma de trabalhadores submetidos ou esposas dos colonos.

Mas fica a questão: como interpretar a inserção de cultos propriamente estrangeiros na polis, ou mesmo a permissão aos metecos de participarem de determinados cultos cívicos? (Clerc 1893). Segundo o modelo, seria absurdo. De todo modo, sendo a religião cívica o núcleo da definição da cidade, e na medida em que o estrangeiro estava excluído do culto cívico, ele também estará excluído da narrativa historiográfica.

\section{A cidade consumidora-estamental}

Este modelo de cidade deriva da abordagem primitivista-substantivista da economia antiga (CARVALHO, 2007), que enfatiza as diferenças entre a economia antiga e a moderna. As origens desta abordagem estão nas análises dos economistas alemães Karl Rodbertus e Karl Bücher, que caracterizavam, no final do século XIX, a economia antiga como "economia do oikos" (Rodbertus) e "economia doméstica fechada" (Bücher): a ausência de comércio e de trabalho livre seriam suas principais características. Contra esta leitura da economia antiga, se levantaram alguns historiadores, como o alemão E. Meyer, dando início à oposição primitivistas/modernistas (WILL, 1954): enquanto modernistas (cujo modelo, a "cidade industrial-financeira", será analisado a seguir) defendiam que, em determinados períodos, as sociedades da Antiguidade apresentaram formações econômicas próximas das modernas (ou seja, economia industrial européia do final do século XIX e início do $\mathrm{XX}$ ), os "primitivistas" argumentavam que existia uma diferença fundamental entre as sociedades antigas e modernas, a saber, que nas sociedades antigas a economia não havia se desenvolvido livremente (ou seja, tornando-se autônoma em relação ao conjunto da sociedade) como nas sociedades modernas, o que impediria, conseqüentemente, a caracterização das sociedades antigas como "capitalistas" ou das cidades antigas como "pólos produtores".

Entre os autores mais representativos do modelo primitivista estão o sociólogo alemão M. Weber, especialmente em seu texto Tipologia das Cidades, escrito entre 1911 e 1913 e incluído na coletânea póstuma Economia e Sociedade (1999), e o historiador estadounidense M. Finley, em sua obra a A Economia Antiga (1986), 
publicada originalmente em 1973. Inserido na própria constituição científica da sociologia, M. Weber, em texto marcado pelo monumental esforço de construção de tipos ideais de cidade (a cidade consumidora, produtora, camponesa, comercial, oriental, árabe, ocidental-antiga, ocidental-medieval etc.), caracterizava a cidade antiga, entre outros elementos, pela ausência de um capitalismo livre e economicamente racional, pois reinava um capitalismo politicamente orientado tanto devido à centralidade da guerra, quanto ao caráter de consumidores dos cidadãos que eram, em si mesmos, proprietários de terra com residência urbana, além da importância social da organização estamental, limitando alguns ofícios para certos estamentos. M. Finley radicaliza a idéia weberiana de "cidade de consumidores" e afirma que devido à ausência de mercados (de trabalho, de exportação, de moeda, de investimentos) e de uma mentalidade aquisitiva por parte das elites, não é possível nem falar em uma "economia antiga"; mais importante do que a posição do indivíduo na estrutura produtiva da sociedade (que, segundo Finley, definiam as classes), era a posição do indivíduo no "espectro de status", que associava prestígio pessoal, ofícios e ordens sociais $^{12}$.

Como os metecos atenienses se inserem neste modelo? Eles são os homo oeconomicus que os cidadãos, por questões estamentais e de prestígio, não poderiam ser. Nas palavras de Finley,

Por que razão Atenas, que elaborou grande número de leis com fortes penalidades para assegurar o fornecimento de cereais importados, vitais para sua subsistência, não legislou sobre quem poderia ocupar-se do comércio de cereais, grande parte do qual estava entregue a não-atenienses? [...] A elite possuía os recursos e o poder político e podia também comandar um vasto pessoal. Faltavalhe a vontade, quer dizer, como grupo (quaisquer que tenham sido as reações de uma minoria) estavam inibidos por valores fundamentais. É decisivo notar que a denúncia habitual dos libertos e metecos, desde Platão até Juvenal, o tema invariável é moral e não econômico. Eram condenados pelos seus vícios e maus costumes e nunca como rivais que roubavam a homens honestos um modo de ganhar a vida" (FINLEY, 1986: 80, grifo meu).

\footnotetext{
${ }^{12}$ M. Finley, em A Política no Mundo Antigo (1985), publicada originalmente em 1983, o autor retornará à noção de "classe social", elemento fundamental de sua explicação da estabilidade política das cidades expansionistas a partir, justamente, da idéia de conflito. Para uma crítica do "finleynianismo econômico", cf. Joly (1999) e Vlassopoulos (2007: 123-42).
} 
Desta maneira, o modelo da cidade consumidora-estamental reduz a subjetividade histórica dos metecos à atividade econômica que os cidadãos não querem (ou não podem) exercer. Mas como se inserem os metecos no espectro de status finleyniano? Não compartilhariam os metecos de Atenas da ideologia anti-econômica da elite; ou seriam eles portadores de uma racionalidade econômica avant la lettre? Ou ainda: quais são as possibilidades de uma ação econômica independente de interferência de estamento ou status, num contexto no qual a economia não se tornou autônoma em relação à sociedade? Ora, a explicação se restringe à visão cívica sobre os metecos (condenação moral, não-econômica), mas não se questiona sobre a natureza econômica da cidade a partir do ponto de vista dos metecos.

\section{A cidade moderna}

Este modelo é o núcleo da explicação "modernista" ou "modernizante" acima citada; tende a explicar as transformações históricas em termos de motivações econômicas e comerciais, enfatizando nas análises as atividades produtivas da polis (contra a "cidade consumidora" dos primitivistas) e a articulação de mercados internacionais, atravessados por uma racionalidade econômica. Um de seus principais autores é E. Meyer, em seu A Evolução Econômica da Antiguidade (1955), texto marcado pela crítica às análises de Bücher, e que ressalta o desenvolvimento de um mercado mundial a partir do século VII a. C. e a constituição de uma política econômica do Estado ateniense voltada para a formação de um império comercial-marítimo, fundando um regime burguês que aliava industriais, comerciantes, marinheiros, artífices e camponeses. Um dos seguidores das análises de E. Meyer foi o historiador russo M. Rostovtzeff, em seu História da Grécia (1973), publicado em 1925, que interpretava a democracia como fruto de uma luta pelo poder econômico e político entre burguesia e proletariado, com a vitória dos últimos e as conseqüentes tentativas de nivelamento não somente das riquezas, como também da inteligência, aos níveis mais baixos do povo vale lembrar que o autor emigrou da Rússia revolucionária de 1917. Depois de um longo período de descrédito (ao lado da hegemonia primitivista), o modelo foi retomado recentemente por dois autores: o historiador estadounidense E. Cohen, em seu livro The Athenian Nation, de 2000, e pelo historiador grego Kostas Vlassopoulos, em seu livro 
Unthinking the Greek Polis, de 2007. E. Cohen, que, além da polêmica defesa de que Atenas é melhor caracterizada como uma nação (no sentido moderno e no antigo, de ethnos), argumenta que a economia ateniense integrava, por meio do mercado de trabalho, os habitantes da cidade independentemente das diferenciações estamentais: daí as análises dos escravos e libertos banqueiros, ou das cidadãs prostitutas; as instituições políticas atenienses aparecem no texto apenas para serem negadas diante da livre iniciativa dos oikoi, numa espécie de "neoliberalismo antigo". K. Vlassopoulos busca uma nova narrativa da História da Grécia, reabilitando o modelo modernista pela via das discussões do "sistema-mundo" de I. Wallerstein (1974) e da "história no e do Mediterrâneo" de P. Horden e N. Purcell (2000); ainda que o autor contribua intensamente para o debate, o autor menospreza os aspectos propriamente institucionais das poleis, diluindo as relações sociais nos "fluxos" de bens, pessoas e idéias.

Apesar das variações, o modelo incorpora o meteco dentro do contexto da expansão econômica de Atenas, que atraía os estrangeiros não devido às proibições estamentais dos cidadãos ao trabalho, mas sim ao crescimento exagerado da economia. Nas palavras de M. Rostovtzeff

Durante este século [V a. C], as duas classes sem direitos civis, os metecos ou estrangeiros residentes e os escravos, aumentaram gradativamente em número e se tornaram mais proeminentes na vida social. A primeira classe foi deliberadamente atraída para a cidade pelos dirigentes políticos. Os próprios cidadãos estavam demasiado ocupados com a agricultura e com os assuntos públicos para darem muita atenção ao comércio e à manufatura. Portanto, os estrangeiros, que não tinham outra ocupação ou interesse a não ser os assuntos comerciais, tornaram-se o instrumento que, mais do que qualquer outra coisa, criou o extraordinário desenvolvimento econômico da Atenas desse século. [...] Isoladamente, não constituíam uma classe: em sociedade, não se fazia distinção entre um estrangeiro e um cidadão (ROSTOVTZEFF, 1973: 179).

Ora, quanto à questão da inserção dos metecos na sociedade ateniense, pode-se observar que a cidade moderna não é tão diferente da cidade consumidora, seu oposto: enquanto os cidadãos fazem política, os metecos (junto dos escravos) são os atores econômicos - a diferença se situa somente na ideologia dos cidadãos. Ainda que existam referências a uma "proeminência social" dos não-cidadãos, estes são relegados, na análise, ao lugar de instrumentos da política econômica dos cidadãos - a própria 
centralidade da economia na explicação historiográfica acaba por excluir uma possível leitura da dimensão subjetiva da sociabilidade dos não-cidadãos.

\section{A cidade de classes}

O modelo da cidade de classes, de inspiração marxista, tende a enfatizar a pertinência dos conceitos de "classe social" e de "luta de classes" na explicação da história da sociedade ateniense ${ }^{13}$. Embora K. Marx não tenha escrito nenhuma obra sistemática sobre a história da "cidade antiga" (greco-romana), este tema está presente em diversos momentos da obra marxiana, inserida em contextos variados, da tese de doutorado sobre Demócrito às análises das especificidades da produção mercantil desenvolvida n'O Capital. A ausência de uma análise sistemática realizada por Marx, aliada ao projeto de construção de uma ciência do materialismo histórico-dialético, deu impulso para que surgisse um debate sobre a polis no interior do marxismo, em suas várias correntes, separadas devido a interpretações divergentes sobre o que seria uma “teoria marxista da História”. No quadro das várias tensões que separam as diversas correntes marxistas, no campo do estudo da Antiguidade a principal divergência é a existência ou não do modo de produção escravista, e sua importância na determinação da estrutura e da luta de classes no mundo antigo. No caso específico ateniense, independentemente se os autores identificam ou não um modo de produção escravista, a luta de classes é centrada em uma luta entre ricos e pobres - exceto em eventos esporádicos (como a fuga dos escravos atenienses durante a Guerra do Peloponeso), a luta (possível) conduzida por escravos é descartada na análise.

Alguns dos principais autores da cidade de classes são: o historiador soviético S. Utchenko, o historiador inglês G. de Ste. Croix, e a historiadora estadunidense E. Wood. Escrevendo na década de 50, S. Utchenko, em seu Classes e estrutura de classes na sociedade escravagista antiga (1984) defende que havia duas lutas de classes na

\footnotetext{
13 "História da sociedade ateniense" e não "história da polis", pois, de acordo com a interpretação do materialismo histórico predominante na tradição historiográfica, o núcleo da História se encontra nas relações sociais de produção específicas a cada sociedade, das quais se derivam as formas estatais. Por isso, serão analisados os conceitos de polis tais como aparecem tangencialmente nas obras dos autores marxistas analisados.
} 
antiguidade, uma fundamental (senhor/escravo), outra acessória (rico/pobre), mas, na democracia ateniense, o desenvolvimento econômico tornava mais complexas as relações entre as classes, com conflitos que se sobrepunham à luta fundamental; infelizmente, o autor não desenvolve este argumento. Em uma das últimas defesas do "escravismo", G. de Ste. Croix, em seu The Class Struggle in the Ancient Greek World, de 1981, propõe que a economia antiga era escravista, pois as classes dominantes (definidas pelo ócio) extraíam seu mais-produto do trabalho escravo, ainda que este fosse insignificante na produção social total; os senhores dominavam o Estado, o que lhes permitia explorar, além dos escravos, os livres pobres - exceto em Atenas, onde a democracia quebrou este monopólio e abriu a luta entre ricos e pobres; quanto aos escravos, o autor afirma que a luta era de mão-única, ou seja, somente de dominação dos senhores. Mais recentemente, E. Wood, em $O$ trabalho e a democracia antiga e moderna (2003), texto escrito no final dos anos 1990, critica duramente a "teoria do escravismo antigo" relacionando-a menos com Marx do que com as ideologias elitistas do século XIX, e propõe alternativamente um modelo para a democracia ateniense como resultado da luta entre ricos e pobres pela propriedade politicamente constituída da terra, dando origem a um regime baseado na hegemonia dos cidadãos-camponeses os escravos ocupariam um papel acessório nestas lutas.

A cidade de classes, diante dos metecos atenienses, encontrou-se perante um dilema: os metecos são uma classe ou um estamento? Sem conseguir definir os metecos como uma classe social distinta, além de não aceitar a validade explicativa do conceito (demasiadamente weberiano) de estamento, os metecos foram em geral deixados de lado na explicação. Nas palavras de Ste. Croix:

Em um sentido, então, os cidadãos de um estado grego poderiam ser considerados uma classe distinta de proprietários de terra, [...] em contraposição aos estrangeiros, embora certamente eles mesmos estariam divididos em classes diferentes em confronto uma com a outra. [... contra aqueles que querem mais atenção aos metecos, o autor argumenta que] a maioria dos metecos que não eram libertos seriam cidadãos em outra polis, vivendo voluntariamente por um tempo em uma cidade que não a sua, provavelmente - exilados políticos ou não - com a intenção de retornar para casa no devido curso. E seguramente metecos não poderiam ser explorados intensivamente: se eles eram [metecos], eles simplesmente iriam para outro lugar (STE. CROIX, 1981: 289). 
Assim, mesmo que tenha dado indicações interessantes quando ao estatuto político da propriedade, assim como possíveis contradições sociais expressas na sociabilidade dos metecos, o modelo da cidade de classes não conseguiu incorporar os metecos na análise.

\section{A cidade institucional}

Partindo da idéia de que existe uma separação entre sociedade e Estado, o modelo da cidade institucional tende a privilegiar a descrição das instituições políticas da polis (natureza, funções), utilizando como base uma história social de seu surgimento e transformações: inspirada na noção aristotélica de politeia (entendida como o conjunto, natureza e estrutura dos elementos institucionais da polis), a história da polis é a história da formação de sua politeia. Entre os principais autores do modelo estão G. Glotz e, atualmente, M. Hansen. O primeiro, historiador francês aluno de Fustel de Coulanges e provavelmente um dos historiadores mais influentes da primeira metade do século XX (TRABULSI, 2001), em seu A Cidade Grega (1980), publicado na França em 1928, discute as contradições entre patriotismo e unificação na Grécia, além de simpatizar claramente com o modelo da democracia (segundo o autor) moderada de Atenas no século $\mathrm{V}$ a.C., por oposição ao arcaísmo espartano e ao individualismo ateniense do século IV a.C., debatendo portanto, indiretamente, com o nacionalismo alemão, o liberalismo e o socialismo. O segundo, historiador dinamarquês cuja obra se estende de estudos sobre os tribunais atenienses (1974) a um inventário das centenas de poleis gregas (HANSEN\&NIELSEN, 2004), entrou em debates sobre a comparação entre a democracia antiga e moderna, criticando em particular, no mundo pós-Guerra Fria, a naturalização ideológica da democracia liberal como modelo único de democracia (1998); sua principal obra histórica individual, La démocratie athénienne à l'époque de Démosthène (1993), segue o padrão da discussão filológica e da descrição institucional.

Ainda que com diferentes discussões, ambos os autores dedicam centenas de páginas à descrição do funcionamento das instituições democráticas atenienses. Se G. Glotz faz uma historia social das instituições como harmonização dos conflitos, M. Hansen defende a importância dos arranjos institucionais como modeladores, inclusive, do modo de vida dos cidadãos. Os metecos atenienses entram no modelo da cidade 
institucional de três maneiras: a partir da listagem de suas exclusões/inclusões instituídas pelos cidadãos (não podem participar da Assembléia ou dos tribunais, não podem ter propriedade de terra, devem pagar um imposto especial, podem participar de determinados rituais religiosos, podem pagar liturgias etc.); também aparecem na sua inserção na vida econômica da cidade, que não é problematizada pelos autores; e, mais marginalmente, a partir da tentativa de burlar as imposições institucionais. Nas palavras de G. Glotz,

Impunha-se preencher duas condições para ingressar na Ekklêsia: 1) era preciso ser ateniense, isto é, cidadão [...]. 2) era preciso ser maior [...]. O controle era facilmente efetuado: bastava consultar o pínax ekklêsiastikós, que era a cópia dos registros afixados nos dêmoi. Mas esses registros, por sua vez, não eram exatos. Os metecos conseguiam neles ser inscritos e, conseqüentemente, infiltrarse na Assembléia. De nada servia lançar contra eles a terrível ação de estraneidade (graphê xênias) que tinha por resultado condenar o réu à escravidão; os "mal inscritos" (hoi paréggraptoi) eram tão numerosos que se fazia necessário, de quando em quando, proceder a uma revisão geral das listas (diapsêphismós). Era raro a Assembléia estar composta, para empregarmos a expressão de Aristófanes, de "farinha pura", sem "farelos" de permeio (GLOTZ, 1980: 127).

Ora, aqui o autor traz elementos importantes para uma pesquisa sobre a dimensão propriamente política dos não-cidadãos: o que significavam estas tentativas de infiltração na Assembléia? Os metecos e escravos não eram simplesmente objetos da regulação institucional - como então contar a história de Atenas por meio de sua organização institucional, sem analisar a efetividade das instituições na prática social? Como o próprio autor afirma, raramente a Assembléia era composta apenas por cidadãos, ou seja, raramente a Assembléia funcionava como deveria funcionar: neste sentido, a história da polis ateniense pode se limitar à descrição do (raro) funcionamento institucional? O modelo da cidade institucional, ainda que ciosamente exclua os metecos da vida política ateniense, seguindo os regimentos, acaba por indicar, até pela própria existência da proibição, uma dimensão propriamente política da sociabilidade dos metecos atenienses. 


\section{A cidade filosófico-existencial}

O modelo da cidade filosófico-existencial se caracteriza por, num projeto consciente de analisar as raízes do Ocidente, buscar uma explicação da originalidade grega na invenção da liberdade, da filosofia e da política, sem recorrer ao "milagre grego": o modelo propõe que o surgimento da polis teria criado um modo de ser específico, centrado na publicidade e laicidade da vida coletiva e na indissociação entre Estado e sociedade. O foco das análises é a história de Atenas, entendida como modelo por excelência de polis grega; podem-se integrar neste modelo duas linhas, a francesa e a alemã. Na primeira, destaca-se J.-P. Vernant (1972), que bastante influenciado por seu professor L. Gernet (1968) e pelos debates entre marxismo, estruturalismo e psicologia social da França na segunda metade do século XX, propõe explicações totalizantes que integrassem a emergência do direito, da filosofia e da política grega a partir da história social da polis - a existência de uma classe média teria tornado possível um equilíbrio social, base da existência da polis. Na linha alemã, destaca-se Ch. Meier (1995), que, escrevendo no último quarto do século XX, realiza um debate com as teorias neoliberais e de crise do Estado-nação afirmando que, ao contrário do mundo moderno, na Grécia Antiga existia uma dimensão da vida, o "político", que era autônoma em relação às outras dimensões sociais a ponto de não ser por elas determinado: a política era um "fim em si mesmo", o que garantiria, por meio da criação de uma identidade cívica plena, o exercício da liberdade coletiva - esta situação existencial do cidadão grego deu origem a uma nova concepção do tempo e do mundo, originando tanto a História quanto a Filosofia.

A história da polis, dentro deste modelo, é, portanto, a história dos cidadãos que exercem seus direitos políticos no espaço público da cidade, situação que trouxe os novos modos de ser no (e de pensar o) mundo. Qual o lugar dos metecos? Na medida em que o meteco não compartilha desta existência política, os metecos não fazem parte da polis para além de base econômica. Em J.-P. Vernant os metecos não são citados nenhuma vez em todo o livro, enquanto os não-cidadãos em geral são citados apenas em uma nota, ressaltando que "a igualdade [dos cidadãos] se esboça num fundo de desigualdade" (Vernant 1970: 47, n. 9). Ch. Meier ainda cita os metecos em uma ocasião, ressaltando que: 
Uma grande parte do trabalho era executada pelos não-cidadãos e escravos, e trabalho e política, casa e polis estavam portanto muito claramente separados. O pertencimento à categoria de cidadão, portanto, continuou o único verdadeiramente importante, mais importante que o pertencimento doméstico. [...]. É na Atenas do quinto século que a identidade política foi realizada do modo mais puro. Para os grandes grupos de cidadãos serem cidadãos (e soldados) era a principal atividade e a principal fonte de rendimentos. Aquilo não seria possível a não ser que uma grande parte da atividade econômica fosse realizada por metecos e escravos, os quais, assim como as cidades aliadas, estavam ali para permitir esta vida política. (MEIER, 1995: 179).

O modelo da cidade filosófico-existencial, francesa e alemã, ao restringir a polis à comunidade de cidadãos, coloca os não-cidadãos em geral e os estrangeiros em particular em uma dimensão não-política, a saber, o mundo econômico. Mas fica a questão: o "universo espiritual" da polis (Vernant) ou o "modo político de ser" (Meier), que ultrapassam os aspectos institucionais da polis, não ultrapassariam também os limites estamentais da cidadania institucional? Não estariam também os não-cidadãos imersos também neste "universo espiritual"? Se sim, abre-se um imenso campo de pesquisa sobre as formas de ação política, possíveis e efetivas dos não-cidadãos. Se não, fica a lacuna sobre o modo de articulação entre o "mundo político" e o "mundo econômico", supondo-se que este realmente existiu de modo autônomo, questão que os autores do modelo não se fazem.

\section{c) Alternativas e possibilidades}

Do ponto de vista do problema da participação dos metecos na sociedade ateniense, a partir da década de 90 começaram a surgir alguns modelos de cidade alternativos à "polis como comunidade e/ou Estado dos cidadãos", que buscam dar conta especialmente das questões de integração e sociabilidade que existiam entre os habitantes de Atenas, cidadãos e não-cidadãos. Dois autores serão analisados: o primeiro, o historiador estadounidense Josiah Ober, procura relacionar, a partir de uma interpretação liberal (baseada no teórico John Rawls), uma "político-polis", restrita aos 
cidadãos, com uma "geo-polis", que incluiria os habitantes de Atenas; em seguida, a historiadora brasileira Marta M. de Andrade, parte da construção de uma noção historicamente constituída de "cotidiano ateniense" (kath'oikian, vida comum ou doméstica) para uma história dos habitantes atenienses que ultrapassasse os controles ideológicos sobre as sociabilidades espaciais dos não-cidadãos.

\section{Da político-polis à geo-polis}

Josiah Ober, em seu ensaio The Polis as a Society: Aristotle, John Rawls, and the Athenian Social Contract (1996, pp. 161-87), propõe uma nova interpretação do conceito de polis em Aristóteles, argumentando que, além de ser "comunidade de cidadãos", a polis indica uma sociedade mais ampla, que inclui cidadãos e nãocidadãos. Interior ao corpo cívico, a polis e sua politeia mantinham consensualmente a desigualdade material, que era amenizava pela igualdade política, pela redistribuição de bens e pelo impedimento de relações de clientela. A partir daí, o autor analisa as relações entre a esfera pública e a privada na polis de Atenas no século IV a. C., mostrando como a sociedade ateniense acompanhava, em linhas gerais, os prognósticos aristotélicos, com algumas brechas de participação política dos não-cidadãos (participação de mulheres, estrangeiros residentes e escravos em processos judiciais, em cerimônias religiosas etc). Neste sentido, e extrapolando a Política de Aristóteles para a própria política ateniense, o autor afirma que "a polis era uma koinonia definida pelas tensões geradas pelo jogo de diferenças entre e dentro da sociedade de cidadãos, da sociedade civil e sociedade como um todo. Tentativas de tratar estas tensões formam a substância da Política de Aristóteles e da política ateniense” (OBER, 1996, p. 187).

No entanto, mesmo que amplie o conceito de polis de modo a abarcar também os não-cidadãos, Ober não o lugar social: ainda que eles sejam pressupostos para a polis (tanto na teoria aristotélica quanto para a prática ateniense), eles fazem parte da polis apenas nas brechas do sistema ${ }^{14}$. De qualquer maneira, o autor abre a possibilidade de se pensar a sociabilidade dos metecos em sua historicidade, inseridos na "sociedade como um todo", apontando a importância da oposição público/privado para este estudo.

\footnotetext{
14 As contradições criadas pelos pressupostos liberais inerentes à argumentação de J. Ober serão analisados mais adiante, no capítulo 5 , item $b$.
} 


\section{De cidadãos a habitantes}

O lugar dos não-cidadãos, e mais além, dos habitantes, é um dos temas do brilhante estudo de M. Andrade, A vida comum: espaço e cotidiano nas representações urbanas da Atenas Clássica (2002). A partir da historicização do conceito de vida cotidiana (associada, nos textos do período clássico ateniense, às práticas sociais nos espaços da cidade habitada) e da crítica da dualidade, por um lado, entre esfera pública (koinos) e esfera privada (idios), e por outro lado, entre espaço público (polis) e espaço privado (oikos), a autora analisa as representações da vida cotidiana no espaço doméstico (kat'oikian), que se refere mais às práticas cotidianas no espaço da cidade habitada do que à "casa", trazendo contribuições analíticas fundamentais para o estudo das interações entre habitantes na cidade:

Essa construção conjunta de vida cotidiana, sociedade urbana e vida doméstica, envolve determinados agentes, determinadas práticas e representações de espaço, que não se enquadram em nenhum dos termos normalmente admitidos para a análise da cidade grega antiga: cidadãos e nãocidadãos, espaço político, esfera pública e esfera privada, etc; assim sendo, de certa forma libera outros agente "menores", outras experiências e vivências daquela sociedade, como por exemplo as mulheres, o espaço doméstico, o olhar do habitante e as interações nesse espaço habitado. Esta é a cidade que precisamos explorar" (ANDRADE, 2000, p. 92).

É dentro de uma história do cotidiano (historicamente concebido) que a autora encontra o lugar dos habitantes da polis ateniense; a "cidade dos cidadãos", ou melhor, os modelos de cidade elaborados a partir do corpo cívico (especialmente Aristófanes e Platão), tomados como representações, são entendidos aqui no contexto de uma tentativa de controle deste espaço social cotidianamente apropriado pelos habitantes: daí a interpretação da comédia de Aristófanes e da teoria política de Platão, Xenofonte e Aristóteles, como propostas de identificação do espaço cívico com o espaço habitado, propostas estas que são indícios, para a autora, de que "as fórmulas anteriores, o discurso cívico, a perfeita identificação da comunidade política com o espaço da cidade [...] estavam perdendo a capacidade de equilibrar o privilégio da cidadania com as 
prerrogativas cotidianas dos cidadãos, nas interações sociais comuns" (p. 231). Esta crise, que, ressalta a autora, não é a "crise da polis", mas dos "modelos de ação coletiva fundados na cidadania como privilégio sobre a apropriação do espaço habitado" (p. 235), teve como manifestação aquilo que a autora chama de "estilização" e "politização" $d a$ vida cotidiana: na medida em que os cidadãos tiveram seus privilégios ameaçados no espaço da vida cotidiana, este último se tornou o palco de negociações e projetos de controle (presentes na comédia, na teoria política, na cerâmica etc).

Com o estudo de M. Andrade, pode-se dizer, está aberto como caminho para uma história do cotidiano na Atenas Clássica focando os habitantes e a cidade habitada, ultrapassando assim a barreira da polis dos cidadãos. Entretanto, esta polis aparece em todo o texto apenas como representação, como modelo, ideologia, projeto de controle: a materialidade da polis dos cidadãos, ou o que foi chamado aqui de polis-institucional, ou está ausente, ou aparece como pressuposto, mas mesmo assim não é desenvolvida juntamente com os outros aspectos analisados. Isso fez com que, por exemplo, no contexto da vida cotidiana, a Assembléia democrática não desempenhasse nenhum papel relevante ${ }^{15}$; de qualquer modo, fica a questão sobre as possibilidades de uma história da vida cotidiana (espacialmente concebida) como independente dos aspectos institucionais objetivos (e subjetivados) da polis dos cidadãos.

\section{A polis como complexo}

Da análise dos variados modelos de polis apresentados pela historiografia ao longo de quase um século e meio, fica a constatação das insuficiências analíticas, geradas pelos próprios esquemas teóricos, de se pensar a sociabilidade dos metecos em sua historicidade. Mesmo que algumas propostas ultrapassem largamente as limitações da "polis dos cidadãos" na direção de uma história da vida cotidiana, como em M. de Andrade (2002), ainda se apresenta necessário um modelo de polis que relacione a sociabilidade cotidiana dos habitantes da polis com a realidade não só ideológica mas também material da polis dos cidadãos, a polis-institucional, e a partir disso se pensar a questão do estrangeiro residente em Atenas em sua dimensão política. Terminaremos este capítulo com algumas brevíssimas indicações que podem contribuir para a

\footnotetext{
15 A questão da ausência das instituições e seus reflexos para a noção de política no texto de M. de Andrade serão analisados no capítulo 9, item a.
} 
reorientação dos estudos sobre a polis, de modo a ultrapassar a "polis dos cidadãos" na direção de uma "polis dos habitantes", mas sem ao mesmo tempo excluir da análise a efetividade das instituições cívicas exclusivistas - parafraseando Aristóteles, indicações por uma construção de um modelo complexo de polis. Não se trata da formulação exaustiva de um modelo alternativo, mas de apenas alguns apontamentos realizados a partir da identificação dos limites e das possibilidades discutidos anteriormente na própria historiografia.

A polis como discurso. A palavra polis tinha múltiplos significados, mas tendia a cristalizar-se em dois, como apontou M. Hansen, a saber: comunidade de cidadãos e sociedade como um todo - nas palavras de J. Ober, político-polis e geo-polis. Longe de procurar colar os significados, imediatamente, à realidade social, podemos entender os significados de polis inseridos num espaço discursivo no qual os significados eram disputados, negociados (M. de Andrade), a partir de duas direções: a tentativa de um ordenamento cívico, que coloca a comunidade restritiva dos cidadãos como identificados inteiramente com a polis (base dos diversos modelos historiográficos analisados); e uma outra, tática, contra este ordenamento, que associava à polis o conjunto dos habitantes, cidadãos ou não. E na medida em que os não-cidadãos se associavam à polis, no nível do discurso, isto apresentava um risco para a própria identidade cívica.

A polis como instituição. Entretanto, a "polis dos cidadãos" não se limita a uma pura existência discursiva, mas possuía também uma materialidade institucional nas relações sociais, como mediação fundamental: era por meio das instituições da polis que se realizava a propriedade da terra, a defesa da polis como um todo pela guerra, a manutenção do aparelho jurídico da escravidão, a organização cívica dos cultos e procissões, dos festivais, entre outros elementos. K. Marx, na famosa passagem sobre a "cidade antiga" das Formen (MARX, 1977: 70), analisa como o caráter simultâneo de pressuposto e resultado da ação social fazia com que a "cidade" (enquanto Estado) assumisse um caráter natural, ou ainda, "sobrenatural, divino". É possível interpretar esta naturalização das instituições estatais da polis como um processo de reificação (como objetivação, cristalização de práticas anteriores - trabalho morto social - no sentido da reprodução das estruturas comunitárias), que se apresenta de maneira diferente para cidadãos e não-cidadãos: aos cidadãos, as instituições tornam possível, por meio da prática política institucionalizada, uma identificação entre o sujeito cidadão 
e o objeto polis no sentido de uma desnaturalização, constituindo assim a identidade como apropriação; aos não-cidadãos, é vedada a participação institucional, constituindo assim um processo de alienação no qual a polis-cidadãos é o Outro dos não-cidadãos ${ }^{16}$ entretanto, como aponta M. de Andrade, existiam espaços de prática social (o espaço doméstico, a vida cotidiana) na qual os não-cidadãos se apropriavam da polis, não apenas no nível do discurso, mas também no nível das práticas sociais.

A polis como sociedade. A partir do que foi dito, fica clara a necessidade de se reabrir o debate sobre a estrutura e a dinâmica da sociedade políade, da tradição inglesa e francesa (FINLEY, 1986; STE. CROIX, 1981; MOSSÉ;VIDAL-NAQUET, 1979), procurando formas de se superar as dicotomias entre "estamento e status" (nas abordagens primitivistas) e "classe social" (nas abordagens modernistas e marxistas) trata-se de desvendar as lógicas específicas que atravessam os grupos sociais em suas relações com a institucionalidade e a cotidianidade da polis, entre estrutura e ação (Guarinello 2004). Ou seja, rediscutir critérios de ordenamento social que permitam a transversalidade de categorizações diversas, de ordem jurídica (estamentos), econômica (classes), ético-moral (status) etc., a partir de suas imbricações na formação de uma determinada totalidade, e em que medida esta mesma transversalidade põe em cheque a própria totalidade. Trata-se, enfim, de recolocar o conflito e a contradição no centro do debate sobre a polis (LORAUX, 2005).

A polis como identidade. Uma das questões que podem ser agregadas a uma nova abordagem é a da negociação da identidade ateniense, não mais reificada em termos de cidadãos-política, metecos-comércio, escravos-trabalho e mulheres-casa, mas inseridas no movimento mais amplo das relações sociais e suas contradições: pode-se observar, por exemplo, nos discursos judiciários do meteco ateniense Lísias (particularmente, lys.12), determinados procedimentos discursivos de deslocamento identitário, pelos quais os metecos passam a ser associados à democracia e à polis, não como homo oeconomicus, mas como sujeito participante. Esta abordagem, efetuada a partir de outras fontes (como, por exemplo, ler a Política de Aristóteles considerando que o autor viveu como meteco ateniense por cerca de quarenta anos), pode resultar em um novo quadro da sociedade políade ateniense. A religião e a guerra também ocupariam papéis importantes para uma rediscussão da "cidadania religiosa e militar",

\footnotetext{
${ }^{16}$ Essa idéia será desenvolvida no capítulo 6, item a.
} 
muito mais inclusiva que a "política-institucional", e quais suas conseqüências para a formulação de uma "identidade cívica" ateniense.

A polis como espaço. Além disso, como bem alertado pela historiografia mais recente (ANDRADE, 2002: 33; MILLETT, 1998), é preciso re-espacializar a polis de modo a perceber as contradições entre apropriação e alienação nos próprios usos do espaço: continuando a polis uma mera abstração institucional, na qual os cidadãos pairam no ar, perde-se uma vasta gama de possibilidades de análise dos espaços de apropriação da cidade habitada pelos não-cidadãos, da "casa" a "regiões inteiras": neste sentido, as análises sobre o porto do Pireu, de intensa habitação dos metecos, (GARLAND, 1987; VON REDEN, 1995; ROY, 1998), dos espaços e circuitos rurais (CHEVITARESE, 2001) e das relações propriamente espaciais entre os vários demoi (OSBORNE, 1990) são etapas fundamentais na construção de uma maior complexidade no estudo da polis.

A polis como forma historiográfica. Finalmente, trata-se de relativizar profundamente as pretensões objetivantes tão comuns na historiografia de tendência empirista, que, sob a capa da (necessária) erudição, acaba por reproduzir teorias e pressupostos de modo nem sempre consciente. Neste sentido, torna-se fundamental o movimento hermenêutico de discussão da polis como discussão de si mesmo, alertando para os limites e para as possibilidades postos pelo próprio movimento da compreensão (RICOEUR, 1990). Ora, a polis é parte da forma "História Antiga" (GUARINELLO, 2003), e, portanto diz respeito tanto à complexidade, fragmentação e desordenamento da documentação (matéria-prima da forma historiográfica), quanto ao tempo presente do historiador. Considerando que, como padrão, ainda se traduz polis como "cidade", "Estado" ou "cidade-estado", vale a pena a discussão sobre o significado destes termos hoje e quais são as possibilidades de tradução, no sentido historiográfico, das realidades sociais daquilo que denominamos polis para a linguagem do mundo contemporâneo. $\mathrm{O}$ termo "cidade" hoje ainda é equivalente ao Stadt weberiano? O que é uma cidade hoje? A ciência política e a geografia urbana, entre muitas outras disciplinas, certamente têm muito a contribuir para uma historiografia da polis que, de princípio, questione o simesmo como ponto de partida (e de chegada) da operação historiográfica. 
2. Homo oeconomicus:

a historiografia sobre os

metecos atenienses 


\section{a) Os metoikoi de Xenofonte}

Os metecos me parecem ser a melhor fonte de rendimento, desde que eles sustentam a si mesmos e não recebem pagamentos ao fazer muitos serviços para as poleis, mas, pelo contrário, contribuem com o metoikion. Eu penso que nós devemos considerar seus interesses suficientemente, se os liberássemos dos

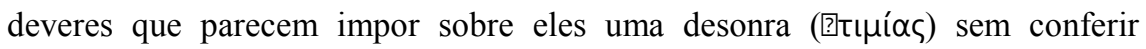
qualquer benefício à polis, e também da obrigação de servir na infantaria junto dos cidadãos: pois grande é o perigo para aquele que o faz, e não é pouca coisa deixar seus ofícios e seus negócios privados. A polis mesma ganharia também se os cidadãos servissem juntos nas fileiras, e não mais se encontrassem nos mesmos batalhões com lídios, frígios, sírios e bárbaros de todo tipo, como são muitos dos nossos metecos: além da vantagem de dispensar os serviços destes

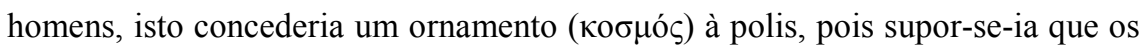
atenienses são mais confiantes em si mesmos para as batalhas do que em estrangeiros. Se, além disso, nós concedermos aos metecos o direito de servir na cavalaria e vários outros privilégios os quais são próprios de conceder a eles, eu penso que nós encontraremos sua lealdade aumentada tanto quanto como a força e grandeza da polis. Novamente, desde que existem vários lugares vagos para casas dentro das muralhas, se a polis permitir a candidatos aprovados erigir casas nestes lugares e conceder a eles a propriedade da terra, eu penso que nós encontraremos uma maior e melhor classe de pessoas desejando viver em Atenas. E se elegermos um corpo de Guardiões dos Metecos ( análogo aos Guardiões dos Órfãos, e algum tipo de distinção destinada para os guardiões cuja lista de metecos é a maior, isso também aumentaria a lealdade dos estrangeiros, e provavelmente todos sem uma cidade (马nó $\lambda \_\delta \varepsilon \varsigma$ ) cobiçariam se tornar metecos de Atenas, e aumentariam nossos rendimentos. (Xenofonte, Poroi, 2.1-7).

Xenofonte, cidadão ateniense, propõe em "Rendimentos" (Poroi) algumas soluções para a crise econômica ateniense, e é neste quadro que aparece uma das raras análises sobre os metecos atenienses que sobreviveram aos séculos. Os metecos não são um gasto para a polis, pelo contrário, são uma fonte de rendimento, em serviços e em dinheiro. Não são especificados quais serviços fazem os metecos (comércio? artesanato? defesa?), somente seu aspecto financeiro: são gratuitos para a polis. Quanto 
à contribuição em dinheiro, trata-se do metoikion: homens pagavam doze dracmas por ano, e mulheres independentes (sem filho ou marido), seis $^{17}$.

Diante desta dupla vantagem, Xenofonte propõe que se considere suficientemente seus interesses, indicando com isso que esta consideração já existia, embora limitada. No texto, quatro "benefícios" são propostos: a liberação do serviço hoplítico, o acesso à cavalaria, a concessão seletiva de propriedade da casa e da terra, e a criação de um aparato institucional específico. Para cada um destes benefícios, há vantagens para metecos e para a polis: sem o serviço hoplítico, ganham os metecos por não ter de se arriscar ou abandonar seus ofícios/oficinas, e ganha a polis em respeito por confiar apenas em seus cidadãos na batalhas; com o acesso à cavalaria, os metecos se sentiriam mais honrados, e consequentemente seriam mais leais à polis; com a concessão seletiva da propriedade da casa, Atenas se tornaria atraente para os metecos ("uma maior classe de pessoas"), além de ter um maior poder de seleção sobre os imigrantes ("uma melhor classe de pessoas"); por fim, com a criação dos Guardiões dos Metecos estes seriam mais leais à polis, apesar de Xenofonte não explicitar as razões para tanto (porque era óbvio?).

Sabe-se que as reformas pelas quais passaram a instituição da metoikia não foram tão radicais quanto aquelas propostas por Xenofonte, e este texto é visto em geral como uma tentativa frustrada: das quatro propostas, apenas a quantidade de concessões de propriedade da casa (enktesis) foi aumentada (WHITEHEAD, 1977, pp. 125-9). No entanto, um aspecto pouco explorado é a relação entre os interesses dos metecos e as considerações da polis. Ora, por quais meios a polis tomava conhecimento destes interesses? Tratava-se de uma especulação filosófica, da qual determinado cidadão deduzia, do estatuto do meteco, suas necessidades e então seus interesses, ou havia meios pelos quais os metecos expunham suas necessidades e interesses? O estatuto de "meteco", a metoikia era posta em questão, e por quais meios? Certamente, estas questões operam uma alteração de foco: não mais a polis decidindo sobre os metecos,

\footnotetext{
${ }^{17}$ Muito se tem discutido sobre o peso financeiro do metoikion: sabe-se que, no século V, uma dracma equivalia a um dia de trabalho, e assim o homem meteco deveria pagar um dia de trabalho por mês. Além disso, o metoikion não era uma parte desprezível da renda pública: apenas quinhentos metecos contribuiriam, anualmente, com um talento; é possível imaginar o impacto da metoikia considerando que no fim do IV século existiam, seguramente, dez mil metecos, número que, segundo as fontes, foi o mais baixo desde a segunda metade do século V. Cf. Whitehead (1977, pp. 75-6).
} 
mas a polis, os cidadãos e os metecos produzindo discursos sobre a metoikia, discursos estes que poderiam, eventualmente, formar a base sobre a qual eram formuladas propostas, fossem quais fossem os meios. Esta alteração de foco permitiria que os metecos deixassem de ser vistos como meros objetos da ação política, ou seja, que fossem reificados pela historiografia; permitiria que a subjetividade dos metecos fosse colocada como um problema historiográfico: como se construiu a identidade dos metecos, e como os metecos se relacionam com esta identidade?

Certamente, o paralelo de Xenofonte entre os metecos e os órfãos não contribuiu para a formulação do problema da subjetividade dos metecos. Mas, de qualquer maneira, o problema pode ser posto para as fontes - particularmente para as fontes produzidas pelos próprios metecos, como os discursos não apenas de Lísias como de outros oradores metecos, como Iseu e Dinarco. Entretanto, esta questão não foi posta pela historiografia da polis, e, no caso da historiografia dos metecos, aparece marginalmente; as discussões em geral se centraram ou sobre aspectos formais deste ou daquele termo, ou sobre se os metecos eram bem ou mal tratados pela polis.

O objetivo deste capítulo é fazer um levantamento de alguns dos principais estudos específicos sobre os metecos realizados do fim do século XIX ao fim do século XX, discutindo seus limites e possibilidades; no final do capítulo, será feita uma análise do discurso Contra Filon (lys.31), ressaltando as questões que este discurso pode apresentar para uma rediscussão da historicidade dos metecos atenienses.

\section{b) Formas e modelos: a reificação da metoikia}

Os estudos históricos sobre os metecos atenienses estiveram intimamente ligados às questões postas pela "questão estrangeira" no mundo (país, cidade) específico do historiador. De isoladas aldeias judaicas a bairros de imigrantes africanos com subempregos, a inclusão do outro no seio da sociedade dá origem a questões que são propriamente sociais: os estrangeiros podem ou não entrar? Podem ou não ficar? Devem continuar sendo estranhos ou devem ser incorporados? Se não, como tratar o "outro interior"? Se sim, por quais meios incorpora-lo sem diluir as fronteiras comunitárias? A quais direitos terão acesso? Para dar contas destas e de outras questões surgem 
argumentos que povoam o debate social, sejam quais forem os meios e a amplitude deste debate.

Os historiadores não estão imunes a estas questões, e em grande medida os estudos acadêmicos sobre os metecos atenienses podem ser lidos como inserções historiográficas em debates sobre a questão dos estrangeiros, tal como ela se configura em tempos e espaços específicos - o que não exclui, vale lembrar, diversas mediações entre a questão social e o estudo historiográfico, tais como a hegemonia de determinadas correntes teóricas, circunstâncias institucionais, afeições pessoais etc. Infelizmente, um estudo histórico sobre os modos como a questão dos estrangeiros se apresentou às sociedades nas quais viveram os historiadores dos metecos atenienses é uma tarefa ampla demais para o presente estudo; não obstante, o esforço se concentrará nas imagens dos metecos atenienses que são construídas nos estudos historiográficos, e em que medida tais imagens se relacionam com a leitura das fontes e com a lógica de apresentação de cada estudo analisado. No futuro, estas imagens tais como emergem das obras poderão fazer parte de uma análise sobre a questão do estrangeiro em suas respectivas sociedades, o que certamente contribuirá para a compreensão dos mesmos valores.

A tradição de estudos históricos sobre os metecos atenienses tem mais de dois séculos: o primeiro estudo inteiramente consagrado ao tema, intitulado Mémoire sur les métèques ou étrangers domicilies à Athènes, foi escrito por Guilhem de Sainte-Croix e lido na Académie des Inscriptions et Belles-Lettres da França em 1785, sendo publicado somente em 1808. Durante o século XIX novos estudos foram realizados, em particular na Alemanha, dentre os quais se destacam a dissertação De metoecis atticis, de M. H. Schenk1, publicado em 1880, e um artigo metodológico intitulado Demotika der attischen Metoeken, de M. Ulrich de Wilamovitz-Müllendorf, publicado em 1887. Baseado fortemente nestes dois últimos estudos, aparece em 1893 a primeira edição de Les métèques athéniens: étude sur la condition légale, la situation morales e le role social et économique des étrangers domiciliés a Athènes, de Michel Clerc, levantamento exaustivo da bibliografia e da documentação disponível à sua época.

A obra de Clerc tornou-se a principal referência para os estudos posteriores que versavam, mais ou menos tangencialmente, sobre os metecos atenienses. Durante o século XX novos estudos apontavam críticas localizadas à obra de Clerc, mas foi somente em 1977, com a publicação de The ideology of Athenian metic, de David 
Whitehead, que o conjunto das teses de M. Clerc foi colocado em questão. Segundo Whitehead (1977, pp. 1-5), a historiografia dos metecos, do final do XVIII ao final do XIX, foi marcada pela ênfase nas condições miseráveis dos metecos em Atenas; isso se alteraria com os estudos de M. Schenkl, U. de Wilamowitz-Müllendorf e M. Clerc, no final do XIX, que passaram a ver os metecos como "quase-cidadãos", como grupo social privilegiado - este modelo, segundo o autor a "moderna ortodoxia", teria predominado nos estudos históricos desde então. D. Whitehead se posiciona contra a "moderna ortodoxia": ao questionar os "privilégios" dos metecos atenienses, o autor ressalta as exclusões e restrições impostas ao grupo.

Nas décadas posteriores surgiriam visões mais nuançadas da relação entre privilégio/restrição, como no livro de M.-F. Baslez, L'Étranger dans la Grèce Antique, de 1984, que enfatiza as vantagens econômicas dos metecos na democracia em certa medida postas em segundo plano no estudo de Whitehead. Mas de qualquer maneira, The ideology of Athenian metic tornou-se a principal referência para os estudos mais gerais que mencionavam os metecos, substituindo o livro de M. Clerc. Digno de nota ainda é a alternativa tanto à "moderna ortodoxia" quando à leitura de Whitehead que surgiu em 1979: trata-se da abordagem marxista de C. Román no texto Los metecos atenienses: um punto de vista sobre las clases sociales em la Antigua Atenas, de 1979, que via nos metecos uma classe social específica de acordo com a estruturação da sociedade ateniense; entretanto, mesmo no âmbito dos estudos marxistas, esta abordagem não conseguiu se impor.

Como relacionar a "questão do estrangeiro", mencionada no início, com o percurso historiográfico dos estudos sobre os metecos atenienses? Como já dito, um levantamento exaustivo é tarefa grande demais para o presente trabalho; entretanto, parece que existe uma problemática comum a estes estudos, qual seja, a problemática da construção dos Estados Nacionais na Europa e da constituição de mercados nacionais, regionais e globais nos séculos XIX e XX. Assim, por exemplo, a Alemanha se constitui como estado nacional apenas na segunda metade do século XIX, tendo que dar conta tanto dos dilemas de integração jurídica, econômica e cultural de regiões díspares, quanto das comunidades que tinha uma integração complexa dentro do Estado e do mercado alemão: particularmente, as comunidades judaicas. A questão judaica certamente não é monopólio alemão, como atesta o famoso "caso Dreyfus" na França do final do XIX e a atividade da Action Française na primeira metade do século XX. Já 
no período posterior à segunda guerra mundial, as transformações na divisão internacional do trabalho, em particular com o desenvolvimento da terceira revolução industrial, deram início a um processo crescente de migração de população dos países ditos "subdesenvolvidos" na direção das economias capitalistas centrais - no caso europeu, a crise dos Impérios coloniais, no terceiro quartel do século $\mathrm{XX}$, ao lado da crise dos países socialistas do Leste dinamizaram o processo de migração que colocava novas questões para os Estados nacionais: como governar um país multi-cultural? Quais medidas tomar diante do crescente afluxo de imigrantes clandestinos, fundamentais para o mercado de trabalho porém à margem da legislação?

Pressuposto a todo este processo, está o movimento duplo de integração econômica e exclusão política do estrangeiro residente, integração e exclusão que contam com mecanismos próprios, de acordo com lógicas que variam tanto no tempo quanto no espaço. Talvez o paralelo seja forçado, mas mesmo assim vale como hipótese: este modelo de integração econômica/exclusão política, com suas definições próprias de economia (economia mercantil capitalista) e de política (instituições estatais) poderia ser a matriz dos modelos dos estudos historiográficos dos metecos atenienses, que em uníssono afirmam que eles estavam integrados nos "mercados" da sociedade ateniense, em particular com os mercados ampliados pelo império no século V, e excluídos das instituições políticas monopolizadas pelos cidadãos. A variação nos estudos fica por conta de se interpretar o estatuto como um privilégio ou como uma exploração, se eles eram mais ou menos integrados socialmente, se eram bem ou mal tratados pelos cidadãos. Mas não se questionam, em tais estudos, nem o estatuto da "economia" nem da "política": transpõem-se categorias contemporâneas, ligadas à experiência dos estados nacionais contemporâneos, para a realidade histórica específica da polis ateniense entre os séculos VII e III a. C.

É para encontrar os limites e possibilidades dos modelos historiográficos sobre os metecos atenienses que se empreenderá a análise a seguir, que, por conta das dificuldades de acesso às obras mais antigas ou mesmo às mais recentes ${ }^{18}$, toma apenas

\footnotetext{
18 Embora não seja citado, na historiografia produzida no século XXI consultada para esta pesquisa, nenhum estudo compreensivo consagrado à questão dos metecos ateniense mais recente que o de $\mathrm{D}$. Whitehead, de 1977; em geral, a produção contemporânea se limita a pequenos estudos sobre aspectos bastante restritos da questão dos metecos atenienses, tais como discussões sobre procedimentos jurídicos abertos ou não aos metecos assim como releituras de fontes, como é o caso do presente trabalho.
} 
quatro entre os estudos mencionados acima: dois estudos exaustivos sobre os metecos atenienses baseados em amplo levantamento de fontes (CLERC, 1893; WHITEHEAD, 1977), um pequeno ensaio sobre a questão dos metecos atenienses como classe social (ROMÁN, 1979), e um capítulo sobre os metecos que faz parte de uma obra geral sobre os estrangeiros na Grécia (BASLEZ, 1984).

\section{Os metecos concidadãos de Michel Clerc}

Grande matriz dos estudos sobre os metecos atenienses no século XX, Les métèques athéniens: étude sur la condition légale, la situation morale et le role social e économique dês étrangers domicilies a Athènes, de Michel Clerc (1893), historiador francês membro da École Française d'Athènes, traça um retrato bastante positivo tanto dos atenienses quanto da vida dos metecos em Atenas. Em uma abordagem que, afastando-se dos estudos limitados aos aspectos legais e institucionais, procura traçar também um quadro do tratamento dado pelos cidadãos aos metecos "na vida de todos os dias" (p. 2), para assim chegar à situação "moral" dos metecos, o autor encontra em Atenas um ótimo lugar para o estrangeiro: discordando de toda a historiografia que não deixou que enfatizar o desprezo que os cidadãos sentiam pelos metecos, o autor afirma que este desprezo é proveniente da aristocracia ateniense, que também não era tão solidária com os cidadãos pobres. Assim, para Clerc,

este desprezo, sincero ou afetado, dos atenienses de alto nascimento ou que tivessem, como Ésquines, uma grande situação no Estado, não influía em nada sobre a conduta de cidadãos em suas relações diárias com os metecos. De fato, cidadãos e metecos viviam da mesma vida, e, aos olhos do observador mais atento, não se distinguia nada entre uns e outros. [...] [O parecer-se com os cidadãos] não era nada junto de um outro privilégio que fazia realmente dos metecos, na vida de todos os dias, iguais aos cidadãos, privilégio que os oradores e os historiadores não deixam de fazer aparecer: é o que o autor da República dos Atenienses [PseudoXenofonte] chama isegoria, isto é, a liberdade de expressão, tão absoluta quanto para os cidadãos. [...] Os metecos tinha a mesma liberdade de comportamento, de movimento, de expressão que os cidadãos,e na rua, não se distinguiam em nada. Atenas era provavelmente a única cidade (ville) onde, no quinto e quarto séculos, a fusão foi alcançada a tal ponto entre os cidadãos e os estrangeiros domiciliados (pp. 230-1). 
Esta fusão entre cidadãos e metecos, Clerc conclui, fazia com que reinasse uma "liberdade e igualdade verdadeiramente democráticas" (p. 232) entre eles; em uma palavra, os metecos "não eram mais estrangeiros, mas concidadãos dos atenienses" (p. 235).

Neste quadro de igualdade e liberdade (mantidas, é preciso lembrar, as condições legais), na qual metecos se tornam concidadãos dos atenienses, qual é a relação entre a polis propriamente e os metecos? De início, Clerc aponta três fatores favoráveis à imigração (e por extensão, favoráveis aos metecos já fixados): o espírito generoso dos atenienses (marcado por "qualquer coisa de nobreza e de desinteresse", p. 319), a valorização do trabalho manual (considerando que os metecos são, majoritariamente, artesãos e comerciantes, p. 321) e a democracia (p. 322). Por que a democracia é favorável aos metecos? Desde Sólon, havia uma valorização da riqueza contra o valor do sangue, inferida pelo autor a partir da organização das classes censitárias solonianas (p. 334); Clístenes, por sua vez, concedeu a cidadania aos metecos e ex-escravos enriquecidos acompanhando a simetria que havia entre a propriedade fundiária e a propriedade mobiliária (p. 337). Dessa forma, na medida em que a sociedade ateniense se tornava mais "liberal" na economia (valorização do dinheiro, do comércio e da indústria), também se "liberalizava" na política (no processo de gestação da democracia), o que resultava numa melhoria da condição dos metecos. Os termos da relação entre a democracia (e a polis) e os metecos seriam: a democracia utiliza os metecos para fins bélicos e econômicos (citando Aristóteles e Xenofonte, pp. 355-6), e os metecos defendem a democracia em troca da liberdade econômica (p. 419).

O livro de Clerc é certamente um marco nos estudos sobre os metecos atenienses, seja pela abrangência, seja pela profundidade. Entretanto, alguns problemas importantes podem ser levantados a partir de uma visão geral da obra de Clerc (além das críticas feitas em quase todo o livro de D. Whitehead). Em primeiro lugar, exageros nas interpretações das fontes de modo a provar sua tese de que os metecos eram muito bem tratados pelos cidadãos, como por exemplo o caso citado no início da isegoria: os autores antigos falam da isegoria dos metecos, mas não que eles tinham liberdade de expressão nas instituições cívicas - extrair daí uma situação de "concidadania" é absolutamente infundado. Em segundo lugar, o autor por vezes se utiliza de categorias psicológicas para fundamentar sua argumentação, como a "generosidade" dos 
atenienses e a "cupidez" dos Tiranos, naturalizando tais categorias e esvaziando, em parte, a explicação histórica. Em terceiro lugar, e oposta à explicação psicologizante, está a leitura economicista das relações entre a polis e os metecos, no sentido de que o comércio e a produção são os vetores fundamentais: é à valorização da propriedade mobiliaria que responde o desenvolvimento da democracia; é para desenvolver o comércio e a indústria e por valorizar o trabalho que a cidade atrai os estrangeiros; é por liberdade econômica que os metecos defendem a democracia; assim, não apenas os metecos agem como homines economici, mas toda a cidade - a economia mercantil é transposta para a realidade ateniense, e as relações entre trabalho e propriedade, economia e política não são problematizadas.

\section{Os metecos a-politicos de Whitehead}

Detalhado no tratamento de uma ampla gama de questões, o livro do historiador inglês David Whitehead The ideology of Athenian metic, de 1977, tornou-se referência obrigatória aos estudos de História e outras disciplinas que se aproximam de questões ligadas aos metecos atenienses. Escrita como tese para obtenção do $\mathrm{PhD}$., sob a orientação de M. Finley, o livro aborda controvérsias que vão das restaurações epigráficas à sociologia dos metecos atenienses, realizando um extenso levantamento documental associado a uma incisiva crítica da historiografia; o objetivo é construir o que seria a "ideologia do meteco ateniense": após uma breve definição do conceito de ideologia "modo característico de pensar de uma classe ou indivíduo", o autor afirma que a ideologia do meteco ateniense é, em primeiro lugar, uma ideologia sobre o meteco ateniense, criada por não-metecos, ou seja, por cidadãos, e em segundo lugar, esta ideologia não se limita a ser formulada e propagada, mas ela é implementada pela tomada real de decisões políticas:

Em uma polis democrática, os politai legislam um estilo de vida para si mesmos, mas a polis não vive somente de politai: forasteiros chegam, e a menos que vão embora, entram na comunidade. E eles, os metoikoi, põem um problema central e contínuo para os politai: se os politai resolvem que a demarcação deve ser mantida eles têm de regular não somente um mas dois estatutos de pessoas livres e determinar as diferenças e semelhanças precisas entre eles. Em tal situação, e especialmente se o grupo excluído do monopólio político começa a fazer uma 
significativa contribuição econômica, intelectual ou artística para a comunidade, sentimentos serão fortes e (frequentemente) conflitantes [...]: ambos os grupos desenvolverão uma percepção de si e do outro, e no caso dos politai isto irá interagir com as decisões concretas que eles tomam como as relativas ao modo como os metoikoi viverão. (WHITEHEAD, 1977, p. 3).

Assim, o autor procura ver a ideologia do/sobre o meteco ateniense tanto nas manifestações pessoais de cidadãos e metecos, quanto, e principalmente, na regulações que a polis faz sobre a questão. É isto que o autor faz na primeira parte do livro, "Analysis", que se debruça sobre as questões de definição do termo "meteco" e de outros próximos (xenos, proxenos, isoleteleis, parepidemos), as fontes para sua história, os direitos e deveres dos metecos e as construções ideológicas (particularmente Platão e Xenofonte) sobre o lugar dos metecos em Atenas. A tônica desta parte do livro é a crítica ao que o autor chama de "moderna ortodoxia", fundada no século XIX por historiadores alemães e franceses, como Ulrich von Wilamowitz-Moellendorff e Michel Clerc, e em larga medida reproduzida nos estudos do século XX. Segundo a moderna ortodoxia, o estatuto de meteco era um privilégio que o estrangeiro recebia da polis, podendo ter uma participação na vida econômica, intelectual e religiosa ao lado dos cidadãos - na expressão de Wilamowitz, os metecos atenienses seriam "quasecidadãos". Contra isso, D. Whitehead faz um levantamento exaustivo das fontes que abordam a relação dos metecos com o sistema tributário, com o serviço militar, com o sistema jurídico; a conclusão do autor é de que a metoikia não era um privilégio, pois: (1) enquanto o xenos, ou estrangeiro antes de ser listado como meteco, era totalmente isento de qualquer imposto ou serviço militar, os metecos deviam pagar o metoikion, (se capazes) pagar as eisphorai e servir como hoplitas; (2) a vida dos metecos, para o direito penal, tinha o mesmo valor que a do xenos, ou seja, menos que a de um cidadão; (3) assim como os xenoi, os metecos eram livres para promover cultos de seus locais de origem mas estavam proibidos de participar na observância de cultos cívicos, exceto provavelmente pela participação (somente) na procissão do festival panatenaico e em alguns cultos locais do demos de residência; (4) como os xenoi estavam impedidos do acesso à propriedade de terra ou de uma casa, a menos que recebem o privilégio da enktesis (provavelmente concedido junto da isotelia); (5) nas dedicações fúnebres, os não-atenienses são referidos não pela sua condição de metecos, mas pela ethnikon, ou 
seja, o nome relativo ao local de nascimento, e além disso, a designação de isoteleis (meteco privilegiado, honrado pela cidade) pode suplantar o ethnikon.

A segunda parte, "Historical Studies", é uma apresentação da história dos metecos atenienses entre os séculos VII e III, a partir da diferenciação e diálogo entre sua existência de facto e seu reconhecimento de iure: no período que vai do final do século VII ao final do V, a população meteca aumenta na medida do crescimento econômico da cidade, impulsionado seja pelas reformas urbanas das tiranias, seja pelo estabelecimento do império ateniense após as guerras médicas; o estatuto legal de meteco, ou seja, estrangeiro residente, diferenciado tanto de cidadãos quanto de escravos e estrangeiros de passagem, tem como marco fundamental as reformas cliestenianas do final do século VI, momento no qual uma definição mais clara dos direitos e deveres dos cidadãos dá a tônica para uma definição semelhante dos estrangeiros residentes, culminando na lei pericleana de 450 que determinava que apenas os filhos de pais e mães atenienses (dupla endogamia) seriam listados entre os cidadãos; este processo seria intensificado na Guerra do Peloponeso, quando as perdas de rendimentos imperiais teria feito com que Atenas passasse a taxar os metecos, instituindo o metoikion (que o autor sugere tenha sido instituído na década de 410 ou antes) e outras medidas de controle sobre esta população. Com a derrota ateniense, a população meteca diminui em relação ao período pré-432, mas mesmo assim continua fundamental para a vida econômica ateniense; a crise dos anos 404-401 gera um intenso debate sobre qual a atitude da cidade diante dos metecos que apoiaram a democracia, mas de todo modo o estatuto de meteco continua estável (não se discute conceder a cidadania a todos os metecos); durante o século IV, a população estrangeira de Atenas passa por uma alteração relativa à permanência, pois se no século anterior predominavam os estrangeiros residentes, lentamente ganhariam maior presença os estrangeiros que não se fixavam pelo tempo mínimo para se tornar metecos (os parepidemoi) - assim, no mesmo momento em que, legalmente, o estatuto de meteco se torna mais definido, a cidade inicia um movimento na direção de regular os parepidemoi, como atesta a criação da dike emporike, procedimento jurídico para o qual não importa o estatuto do litigante; por fim, a metoikia como instituição começa a desaparecer das fontes entre o século IV e III, diante do que o autor argumenta que, ao invés de um enfraquecimento da distinção entre cidadãos/metecos (que a historiografia associou à crise da cidadania do período helenístico), foi a distinção entre 
metoikos/parepidemos, ou seja, estrangeiro residente/estrangeiro de passagem, que se enfraqueceu no século III, de acordo com as transformações econômicas e sociais da Atenas helenística.

Após este percurso, podemos questionar: qual é a ideologia sobre o meteco ateniense segundo D. Whitehead? Segundo o autor, quando o estrangeiro chega em Atenas a decisão fundamental é recebê-lo; porém, quando a questão é admiti-los como iguais, a decisão é não faze-lo (p. 69). A criação de um terceiro estado, entre cidadão e escravo, faz com que o meteco, ainda que como o cidadão seja livre, esteja excluído das timai (honras, dignidades) dos cidadãos, quais sejam: to archein, a participação na assembléia e nas magistraturas, to dikazein, o direito de ser jurado em tribunal, e he hierosyne, o direito de exercer o sacerdócio. Segundo o autor:

Nenhuma quantidade de concessões menores compensa estas exclusões básicas. Um apelido mais apto que "quase-cidadão" seria "anti-cidadão", a imagem negativa, sugerindo não tanto uma dicotomia homo politicus/homo oeconomicus quanto uma homo politicus e (se o solecismo me é permitido) homo apoliticus: se o meteco realmente era, ou se pensava ser, homo oeconomicus, isto é em grande medida porque importantes esferas de atividade estavam fechadas para ele. (WHITEHEAD, 1977, p. 70).

O meteco como homo apoliticus seria o resultado da ideologia do meteco ateniense tal como construída pelos cidadãos. Mas como explicar a participação política ativa dos metecos na restauração democrática de 403? Para Whitehead, a "ideologia oligárquica" era contrária ao estrangeiro (Esparta e a xenelasia como paradigma), e a oligarquia dos Trinta significou uma grave ameaça à segurança dos metecos, e isto explica a atuação dos metecos: o meteco é normalmente um homo apoliticus, tornandose politicus somente diante do perigo - participação política ativa dos metecos na restauração é a exceção que prova a regra.

Mas, pode-se questionar, como se dá esta transição? O que seria exatamente um estado apolítico e outro político? Afinal, o que é política para o autor? Ora, D. Whitehead define a política, citando Aristóteles, por meio das timai, das dignidades dos cidadãos: ser membro da assembléia, ser magistrado, ser júri, ser sacerdote; isto gera um raciocínio circular: política é aquilo que o cidadão faz, logo só o cidadão faz política. $\mathrm{O}$ autor, apesar de fazer um brilhante levantamento da "ideologia dos cidadãos atenienses a respeito do meteco ateniense", não faz sua crítica, e concorda com seus pressupostos. 
Neste sentido, não há qualquer conflito: cabe aos metecos, aos bons metecos aliás, aceitarem a ideologia que os coloca como homines apolitici. A única contestação possível está no desrespeito às leis: a infiltração dos metecos na instituições - mas a polis já está preparada, como prova a graphe xenias, o procedimento jurídico que leva à morte o meteco que fingir-se cidadão. Esta construção impede que Whitehead perceba como o conceito de política, assim como os parâmetros da cidadania, também é parte de uma disputa que pode se dar seja nos níveis discursivos, seja nos níveis da ação prática. Política é o que o cidadão considera que é política: a ideologia cívica sobre o meteco se torna premissa da pesquisa historiográfica.

Entretanto, um item no sumário do livro pareceria indicar uma reviravolta nesta construção: "the metic viewpoint". Seria então uma análise do ponto de vista dos próprios metecos em relação a si mesmos, à cidade, à democracia? De um livro com 200 páginas, a análise do "metic viewpoint" conta com magras 3 páginas. Trata-se de uma brevíssima discussão da noção de metoikia presente nos discursos de Lísias e nos livros de Aristóteles: quanto ao primeiro, limita-se a observar o modelo contratual das relações entre a polis e os metecos, além do uso valores presentes em outras fontes, como a disciplina (kosmios) e o bom comportamento (sophrosyne); quanto ao segundo, nota a falta de envolvimento emocional de Aristóteles sobre o tema e o paradoxo de se estudar a comunidade de cidadãos diante da importância da comunidade meteca de seu tempo, além de breves considerações sobre a psicologia dos metecos que "não querem o que não podem". O que é a polis para Lísias e para Aristóteles? E mais fundamentalmente: a política em Aristóteles, como os conhecimentos relativos à polis, se limitam às dignidades dos cidadãos? $\mathrm{D}$. Whitehead se limita a reproduzir o discurso cívico (presente em Aristóteles!) sem questionar se os autores fazem no texto o que enunciam como pressupostos, evitando assim as contradições que poderiam abrir análises mais detidas sobre o "ponto de vista meteco". A política mantem-se monopólio dos cidadãos, não porque era, mas porque os cidadãos diziam que era - a ideologia se torna evidência.

\section{Os metecos (às vezes) alienados de C. Román}

Uma interessante apropriação de algumas hipóteses de Clerc, tomadas sob um ponto de vista marxista, é realizada por C. G. Román (1979), no texto Los metecos 
atenienses: un punto de vista sobre las clases sociales en la Antigua Atenas. Neste texto, o autor trata do estatuto social dos metecos, e a partir de textos especialmente de K. Marx e de G. Lukács, conclui que os metecos constituíam-se como uma classe social, na medida em que, no modo de produção específico da formação social ateniense, pré-capitalista, era o critério político que determinava as classes sociais, e não o econômico, específico do capitalismo; por conseqüência, é a dominação política (restrição da política aos cidadãos) que fundamenta a exploração econômica (proibição da propriedade fundiária aos não-cidadãos). As classes sociais são definidas em suas relações políticas, e em Atenas, a partir do pertencimento ou não ao corpo cívico: a democracia é instrumento de dominação dos cidadãos sobre os não-cidadãos.

Dominação política, desigualdade social, exploração de classe - nada mais oposto ao modelo de M. Clerc. No entanto, é ao discutir as possibilidades da consciência de classe dos metecos que ocorre uma aproximação com as teses de Clerc. Citando Lukács, o autor afirma que os metecos não tinham uma consciência de classe clara e definida, posto que se tratava de uma estrutura pré-capitalista; exemplo disso é o apoio meteco à restauração democrática: citando Clerc, o autor afirma que os metecos defenderam a democracia (instrumento de dominação dos cidadãos) pois esta permitia sua atividade econômica, enquanto a oligarquia não (p. 147). Ou seja: os metecos tinham consciência de classe para derrubar a oligarquia em nome de seus interesses econômicos, mas não a tiveram para derrubar também a democracia, instrumento de dominação dos cidadãos. Qual seria o limite da consciência de classe? Ou: por que a economia se autonomizou enquanto pensamento e prática no primeiro caso (contra a oligarquia), mas não no segundo (contra a democracia)? O economicismo de Clerc é retomado, e as incoerências deste esquema são atenuadas com a idéia de "falta (ou excesso) de clareza" na consciência de classe dos metecos, de acordo com a situação escolhida pelo autor.

\section{Os metecos contratualistas de Baslez}

Diversa da abordagem marxista, a interpretação da questão dos metecos atenienses do livro L'Étranger dans la Grèce Antique, da historiadora francesa MarieFrançoise Baslez, rediscute a relação privilégio/exploração dando uma ênfase especial para as vantagens econômicas ao lado das exclusões políticas. O livro se propõe como 
uma história geral das relações cidade/estrangeiro na Grécia Antiga dividida em três partes: "as tradições de hospitalidade" (que corresponde aos períodos homérico e arcaico), "o cidadão e o estrangeiro (período clássico)", e o "cosmopolitismo da cidade" (período helenístico); o método desta história geral seria o estudo diacrônico tanto da política quanto das mentalidades e do cotidiano.

O dilema da cidade, segundo a autora, é "mais ou menos aquele de um Estado moderno": conjugar, de um lado, a necessidade de fechamento da cidade resultante da estruturação da cidadania, e de outro, a necessidade de abertura da cidade que atrai os imigrantes devido à sua prosperidade econômica e que necessita deles para executar as tarefas das quais os cidadãos, com a estruturação da vida política, estão liberados (p. 90). Associando a democracia ao fechamento, a relação da cidade com os estrangeiros em Baslez é contratual: em troca da proteção e da permissão à atividade econômica, o estrangeiro deve ser fiel ao regime, e principalmente não praticar fraudes para participar politicamente (p. 99-101). Este contrato garantiria para o meteco as imensas vantagens de se estabelecer no centro de diversos fluxos mercantis, em particular durante o apogeu do império ateniense em meados do século $\mathrm{V}$.

Sendo este contrato ("proteção econômica/fidelidade política à distância") a referências das relações entre os metecos e a cidade, surge uma oposição moral entre o bom e o mau meteco. A autora utiliza como exemplos Lísias, o bom meteco, e Atenógenes, o mau. Enquanto o primeiro é fiel à democracia e prospera economicamente mantendo-se à margem da cidade, o segundo é caracterizado como um escroc tanto na vida privada como na vida pública: tentou vender uma loja endividada, não cumpria seus deveres familiares, e, além disso, fugiu de Atenas durante a batalha da Queronéia e tentou voltar quando a paz foi restabelecida.

Neste ponto, exatamente, aparecem as limitações da análise de Baslez, pois é sempre do ponto de vista da "cidade" que se fala dos metecos. A noção de "utilidade para a cidade" (p. 90) é ilustrativa. Mais do que isso, os documentos para a definição do bom o do mau meteco não passam por qualquer crítica: para o bom meteco Lísias, o documento utilizado é de autoria do próprio Lísias (Contra Eratóstenes), e portanto, dificilmente ele se auto definiria negativamente; para o mau meteco, o documento é um discurso do orador Hipérides “contra Atenógenes", sendo também difícil conceber que o orador definiria seu oponente positivamente, seja como meteco ou como qualquer outra categoria. Os documentos, que são discursos retóricos, se tornam reflexos da verdade, e 
as tensões e contradições são anuladas em nome da construção das noções de bom e mau meteco, sempre do ponto de vista da cidade.

Além disso, está o economicismo da definição do meteco como homo economicus (p. 128), fundada em uma concepção de que a política (tanto prática quanto representação) está restrita aos cidadãos, como se, ao deixar sua cidade, o meteco deixasse também sua característica fundante como grego, a saber, a de ser antes membro de uma família e de uma cidade (p. 18), para tornar-se um indivíduo guiado por motivações econômicas, exercendo apenas um papel secundário nas atividades propriamente cívicas (p. 132-9); sobretudo, quanto aos destinos das migrações de metecos, "o critério étnico ou político não exerceu nenhum papel” (p. 146). Mas como explicar as tentativas de fraude para ingresso no corpo cívico? Seria influência dos maus metecos? Ou ainda, como explicar o apoio meteco à restauração democrática de 403, ou seja, a mesma democracia que dirigiu os processos de fechamento do corpo cívico? Notavelmente, Baslez, citando inclusive Lísias, afirma que "o meteco ateniense não tinha qualquer interesse particular à democracia" (p. 147-8). Mas quais características "gregas" estariam ainda presentes no meteco oriundo de outra cidade grega? "O devotamento à coisa pública e sua generosidade. Deste ponto de vista, o contrato proposto ao meteco [...] se endereça a um grego" (p.149). Assim, transpondo à Grécia Antiga uma ideologia cara aos "Estados nacionais modernos" diante do afluxo de imigrantes pobres, a autora faz com que a submissão e a redução às atividades produtivas sejam as características "gregas" dos metecos - ou seja, é ao tornar-se nãogrego (apolítico) que o meteco demonstra que é grego (devotado à polis).

\section{c) O abandono da liberdade: cidadãos e metecos em Contra Filon (lys.31)}

Aqueles que abandonam uma fortificação, um navio ou um campo militar (se acontece de ter cidadãos nele), sofrem as mais severas punições; este homem, que abandonou a polis inteira, procura obter não somente a impunidade, como também uma honra! Aquele que visivelmente abandonou a liberdade ( 
não com a exclusão do Conselho, mas com a escravidão e a privação total de direitos (31.26).

O discurso Contra Filon conta a história de um cidadão ateniense que se tornou meteco em outro lugar, no momento mesmo que sua polis estava em risco: por essa razão, seria monstruoso que Filon, o cidadão em questão, assumisse um assento no Conselho dos Quinhentos, ou seja, que ocupasse um cargo de comando na polis. O discurso 31 do Corpus é parte de uma dokimasia, ou seja, um exame prévio de admissão de candidatos a algum cargo público (no caso, um assento no Conselho). Neste procedimento, a única punição é a desonra pela não admissão do candidato. A datação mais provável é o início do século IV, não muitos anos depois da restauração de $403^{19}$

Habitual nos discursos de dokimasiai do Corpus de Lísias, a base da argumentação é o comportamento do candidato durante o regime dos Trinta. Entretanto, não se tratava de demonstrar que Filon era um apoiador ativo da oligarquia (como em Contra Evandro, lys.26), ou que, permanecendo na polis, agiu como um democrata do Pireu agiria (como em Defesa a uma acusação de subverter a democracia, lys.25): Filon é acusado de não ter tomado parte no conflito, ou seja, de não ter se posto nem ao lado dos oligarcas, nem dos oligarcas, preferindo permanecer fora de Atenas durante os conflitos.

Segundo o orador, Filon, ao não ser listado entre os Três Mil (cidadãos com plenos direitos) pelos Trinta, foi banido da asty, indo se fixar no interior da Ática. Quando os exilados retornaram a File e depois partiram para o Pireu, dando início às lutas pela restauração da democracia contra os oligarcas "que permaneceram na asty", Filon reuniu sua propriedade e partiu para Oropus ${ }^{20}$, para lá se fixar como meteco, sob a

\footnotetext{
${ }^{19} \mathrm{O}$ discurso não menciona nenhum evento conhecido posterior à restauração, no entanto, ao desculpar-se da falta de testemunhas para uma das acusações a Filon, a saber, de ter assaltado camponeses idosos ainda na época da oligarquia, o orador diz que estes não compareceram ao julgamento em função de sua idade e fraqueza, e não da eventual morte de alguns - isso faz com que, por exemplo, C. Carey afirme que o caso não teria ocorrido muitos anos após 403, pois se assim o fosse, o orador teria usado a morte de alguns como argumento (CAREY, 1989, p. 179).

${ }^{20}$ Oropus, cujo porto era usado pelos atenienses para o recebimento do trigo produzido no mar Negro (substituído pelo Pireu durante a guerra do Peloponeso), era uma área de disputa entre Atenas e Tebas, mas, ao que parece, entre 404/3 era, talvez apenas formalmente, uma polis separada tanto de Tebas quanto de Atenas (TODD, 2000, p. 308, n.2).
} 
responsabilidade de um prostates e pagando o metoikion, a taxa dos metecos; segundo o orador, Filon preferiu "ser meteco [entre os cidadãos de Oropus] a ser cidadãos entre nós" (31.9). Em Oropus, Filon teria aumentado sua propriedade, e só retornou a Atenas quando a paz já havia sido estabelecida entre os oligarcas e os democratas.

Mas seria crime não participar de uma guerra civil na polis? Uma lei soloniana do século VI a. C., citada na Constituição de Atenas de Aristóteles, prescrevia: "aquele que, quando houver dissensões ( $\sigma \tau \alpha \sigma \iota \alpha \zeta o u ́ \sigma \eta \varsigma)$ na polis, não dispor de suas armas com

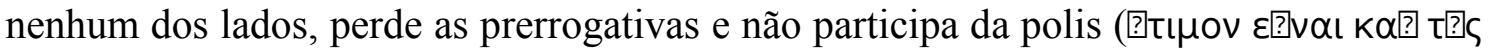

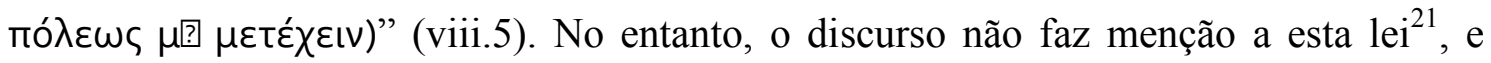
mais do que isso, diz expressamente que não há lei contra tal conduta. Mas a esta ausência legal se torna a base para um interessante argumento de antecipação:

Ouço ele falar que, se fosse um crime não se envolver $(\mu$ ?

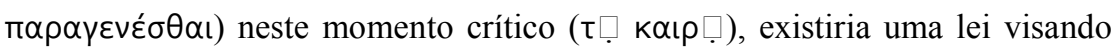
isso expressamanente, como existem para outros crimes. Ele não prevê que vocês perceberão que foi a enormidade do crime que impediu a formulação de uma lei sobre ele. Qual orador teria imaginado ou qual legislador teria previsto que um cidadão seria culpado de tal crime? (31.27).

Desse modo, a ausência da lei, ao invés de significar a ausência do crime, indica na verdade a sua enormidade - abandonar a polis quando ela própria está em perigo (ou seja, durante uma stasis, uma guerra civil) é um crime que está aquém da legislação. Partilhar a sorte da polis é o acordo prévio da cidadania, a partir do qual as leis podem ser feitas - a leis punem os crimes cometidos pelos cidadãos, mas não há lei para o cidadão que nega sua condição, ou seja, que não toma posição em uma stasis. Em diversos momentos do discurso o orador busca o ressentimento especialmente dos exilados - Filon não contribuiu com a causa democrática (CAREY, 1989, pp. 181-2) -, mas também enfatiza que ambos os lados, oligarcas e democratas, devem ficar ressentidos contra o acusado, pois ele, sem qualquer impedimento físico ou financeiro, não se associou a nenhum dos dois (31.13).

\footnotetext{
${ }^{21} \mathrm{O}$ que fez com que alguns estudiosos duvidassem da existência dela (seria uma construção do século IV?), ou mesmo que, se ela fosse genuína, estaria já obsoleta na época do discurso Contra Filon. Cf. a discussão bibliográfica sobre a lei soloniana em C. Carey (1989, p. 198-200).
} 
Este não é o único motivo para que Filon seja recusado ao cargo de membro do Conselho: o orador dirige mais duas acusações contra Filon. Durante sua permanência como meteco em Oropus, Filon, à frente de outros "que transformavam em boa sorte a desgraça" da polis (31.17), realizou roubos contra a propriedade de camponeses pobres e idosos no interior da Ática. Além disso, sua própria mãe, no fim da vida, não confiou nele para cuidar de seus rituais fúnebres: com medo que Filon tomasse para si o dinheiro, sua mãe entregou as três minas de prata necessárias para seu enterro a um certo Antifanes, que nem era seu parente - segundo o orador, este era um indício do comportamento criminoso de Filon, pois, se normalmente as mães são bastante tolerantes com os filhos, nem a própria mãe de Filon confia nele: o que o júri deveria pensar se a própria mãe de Filon "esperava que este homem a roubaria mesmo depois de sua morte?" (31.22).

Dessa maneira, Filon é responsabilizado por crimes em três níveis: não se posicionar durante a stasis (indiferença contra a polis); assaltar camponeses (roubo contra os cidadãos); não ser confiável na garantia de enterro de sua mãe (impiedade contra o oikos). Nestes três níveis, na argumentação do orador, foram o valor à sua segurança pessoal ou o desejo de aumentar sua propriedade privada (acima dos deveres com a polis, com os cidadãos, com a família) as bases da ação criminosa de Filon estas duas razões justificam, para o orador, a recusa de Filon para o Conselho.

No entanto, o que está em questão no discurso não é apenas a admissão ou recusa de Filon, mas a própria definição da ética do cidadão, e da adequação desta ética a um cargo de comando na polis. Filon é um cidadão que coloca a segurança pessoal e a propriedade privada acima dos deveres coletivos, e um cidadão com tal ética não pode ser admitido no Conselho. Este pressuposto é enunciado no discurso antes mesmo da apresentação dos crimes, quando o orador diz:

Eu simplesmente digo que somente têm o direito de deliberar [ser conselheiro] sobre nossos assuntos aqueles que não apenas tem o título de cidadãos, mas que também o são realmente. Pois, para estes, existe uma grande diferença se a polis é próspera ou não - eles se sentem obrigados a participar de suas desgraças assim como de seus benefícios. Mas aqueles que, cidadãos de nascimento, têm por princípio que a pátria está em todo lugar onde eles possuem negócios, estes serão evidentemente os que trairão os bens coletivos

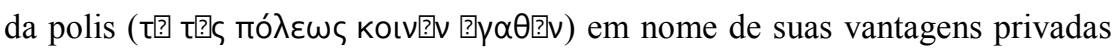

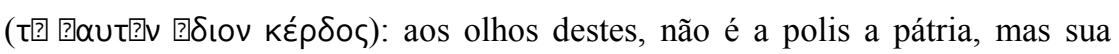




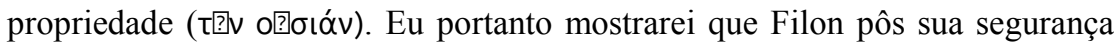
pessoal acima do perigo comum, e que preferiu bem mais passar a vida sem risco que enfrentar o perigo pela salvação da polis, como fizeram os outros cidadãos (31.5-7).

De um lado, o bom cidadão que partilha a sorte da polis; de outro, o cidadão que considera a propriedade como sua pátria: eis o homo oeconomicus, e, justamente, ele está entre os cidadãos. O que é a polis para o cidadão que submete seus deveres ao idios kerdos, à vantagem privada? A polis é um espaço para a realização de sua propriedade, que aliás pode ser realizada em qualquer outra polis (Oropus): o conteúdo político da polis desaparece quando ela se torna apenas continente da ação privada - o fim da diferença política das polis dá origem ao cidadão indiferente à polis, e o "patriotismo das coisas" fundamenta um "cosmopolitismo apolítico". A conseqüência para a comunidade cívica é o enfraquecimento de seus laços, posto que o cidadão indiferente, apolítico, não partilha de sua sorte, podendo se tornar meteco em qualquer lugar onde tenha negócios. A riqueza, portanto, dissolve as fronteiras políticas por meio da criação de um espaço que só se indiferencia do ponto de vista da realização da propriedade trata-se da diluição do espaço cívico pela criação do espaço da $\operatorname{propriedade}^{22}$ : a passagem de um espaço a outro é marcada, no discurso, com a transformação de Filon de cidadão em Atenas a meteco em Oropus: o meteco é por excelência o habitante deste espaço da propriedade.

"O cidadão grego é o homo politicus" e "o meteco é um homo oeconomicus" são duas das frases basilares da historiografia sobre a polis e sobre os próprios metecos. $\mathrm{O}$ argumento é bastante simples: os cidadãos monopolizam as instituições políticas; os metecos ficam de fora da política; logo aos metecos resta a atividade econômica. Daí que os metecos apareçam nos estudos sobre a polis ateniense de duas maneiras principais: ou ao lado dos outros excluídos (mulheres, escravos), ou dentro do quadro do crescimento econômico da polis (artesanato e comércio, pois somente os cidadãos podem ser proprietários fundiários). Se alguma relação é feita entre a política e os metecos, são os modos como a democracia ou a oligarquia trata os metecos, a legislação

\footnotetext{
${ }^{22} \mathrm{O}$ termo espaço econômico está sendo evitado por conta das questões postas pelo próprio discurso, que opõe a vantagem privada também ao oikos, haja visto a desconfiança da mãe de Filon a respeito de seu funeral.
} 
sobre o comércio e sobre o artesanato etc., raramente sobre as atitudes dos metecos diante da democracia.

No entanto, o discurso Contra Filon apresenta uma visão mais complexa da questão metecos/economia e cidadãos/política. Filon é um cidadão de nascimento, na época do discurso acima de 30 anos, e portanto apto para pleitear um assento no Conselho. No entanto, sua conduta anterior, segundo o orador, demonstra que ele coloca a propriedade privada acima da polis, ou seja, que ele guia sua conduta em nome de interesses econômicos, privados, indiferente para deveres cívicos, comunitários, familiares. A partir desta condição, para Filon independe seu status: cidadãos ou meteco, está onde seus interesses econômicos o levam. Portanto, Filon é antes homo oeconomicus, e depois meteco e mau cidadão.

Filon prioriza a propriedade privada por qualquer motivo, menos por estar impedido de participar das instituições políticas de Atenas. A dualidade cidadão/política e meteco/economia aparece aqui como prescrição (o dever-ser), não como fato, como considerou tradicionalmente a historiografia. No discurso existem indícios de que a priorização da economia (ou o "abandono da liberdade") existia entre os cidadãos, o que criava a indiferença quanto à polis e quanto ao estatuto que a polis confere ao indivíduo (cidadão, meteco).

Mas estaria o outro termo da dualidade, metecos/economia, também em questão no discurso? Após discutir a questão da ausência de lei contra a indiferença política, diz o orador:

Todos teriam razão em criticar vocês [membros do Conselho], se, tendo recompensado os metecos de uma maneira digna da polis por terem auxiliado a democracia além de seu dever, vocês não punirem meu oponente por ter traído a polis em oposição ao seu dever, ao menos com o tipo de desonra (?ıนía) disponível hoje, se não mais severamente (31.29).

Neste trecho fica clara a relação entre prescrição e fato: não fazia parte dos deveres dos metecos a defesa da democracia, no caso, a luta contra o regime dos Trinta, luta que na verdade seria um dever dos cidadãos. Os metecos fizeram mais do que lhes foi determinado, Filon fez menos: esta dissociação se dá pela concessão de honra pela polis, honra aos que foram além, desonra aos que ficaram aquém. Mas qual é este além dos metecos que apoiaram a democracia? Ora, dificilmente o mais moderado dos 
estudiosos classificaria o apoio à restauração de um regime político como uma atividade econômica. Não seria o caso de classificar esta atividade como política, mesmo que ultrapasse as instituições cívicas? Dessa maneira, ao lado da participação política dos metecos atenienses, estaria a própria definição de polis sendo posta como objeto de uma nova leitura.

O apoio meteco à restauração democrática de 403 foi um ato além do determinado pela polis, o que, a meu ver, levanta duas questões centrais: em primeiro lugar, em que medida e por quais meios as prescrições da polis sobre os habitantes são impostas e são questionadas, e em segundo lugar, quais são as possibilidades de ação política dos não-cidadãos para além dos limites institucionais. Uma resposta para tais questões demandaria uma pesquisa bem maior do que a presente, mas de qualquer modo fica indicada a crítica a uma visão reificada dos metecos como homines oeconimici, predominante na historiografia, que toma as prescrições cívicas (cidadãos com a política, metecos com a economia) como informações imediatas da realidade social: trata-se, antes de tudo, de analisar os discursos de modo a expor suas contradições, suas fraturas, suas brechas, para desse modo se construir uma nova historiografia que tome a polis não como uma coisa em si, mas como uma constante construção discursiva, da qual temos apenas alguns vestígios materiais e textuais; e que possa revelar, no movimento mesmo desta construção, as tensões e as lutas que envolveram a imposição e a contestação de um determinado enquadramento (a polis dos cidadãos, o espaço cívico, a política restrita às instituições) a uma determinada prática social (a polis dos habitantes, o espaço cotidiano, a política fora das instituições); em uma palavra, trata-se de uma mudança da ordem para as fronteiras da ordem. 


\section{PARTE II:}

Fonte

Insisto, solerte.

Busco persuadi-las.

Ser-lhes-ei escravo de rara humildade.

Guardarei sigilo de nosso comércio. Na voz, nenhum travo de zanga ou desgosto. Sem me ouvir deslizam, perpassam levíssimas e viram-me o rosto. Lutar com palavras parece sem fruto.

Não tem carne e sangue...

Entretanto, luto. [...]

Carlos Drummond de Andrade, O Lutador. 
3. Papiros e tribunais: os discursos de Lísias e o direito ateniense 


\section{a) Questões sobre o Corpus: Antigos e Modernos}

Os discursos de Lísias, entre textos integrais e fragmentos, estão presentes nos estudos clássicos e na historiografia atual de dois modos opostos: se por um lado os especialistas no Corpus multiplicam as incertezas - quanto à datação, autenticidade, biografia do autor etc -, os historiadores, particularmente os da tradição britânica, citam os discursos de Lísias como "evidência” para "provar" determinadas hipóteses, como se entre os discursos e a realidade histórica houvesse uma correspondência automática. A discussão a seguir procurará, por um lado, listar as certezas e incertezas quanto aos textos (biografia de Lísias, estilo e retórica, transmissão dos manuscritos e autenticidade), e por outro, levantar questões sobre o modo pelo qual os discursos têm sido utilizados na pesquisa historiográfica.

\section{Biografia}

Apesar da preservação de dois discursos autobiográficos do próprio Lísias, da menção a aspectos de sua vida em textos de Platão e Demóstenes, e de duas biografias integrais de Lísias, além de pequenas referências em índices bibliográficos antigos, diversas dúvidas pairam sobre os atuais estudos de Lísias: desde dados fundamentais como ano de nascimento e de morte, até a discussão sobre se ele continuou meteco ou se adquirira a cidadania. Os principais documentos que mencionam a vida de Lísias são: do século V a. C., os discursos Contra Eratóstenes (integral) e Contra Hippotherses (fragmentos), escritos, segundo as indicações em manuscritos e papiros, pelo próprio Lísias; do século IV a. C., a República e Fedro, de Platão, e Contra Neaira, de Demóstenes (ou Apolodoro); do século I a. C., o estudo Lísias, de Dionísio de Halicarnasso; e do século I ou II d. C., a Vida de Lísias, de Pseudo-Plutarco.

Do discurso Contra Eratóstenes, escrito provavelmente em 403 a. C., extrai-se que: 1) Lísias era filho de Céfalos, rico siracusano que migrou para Atenas a convite de Péricles, e lá viveu trinta anos; 2) sua família não se envolveu em qualquer ação judicial antes do regime dos Trinta, tendo vivido como metecos cumpridores de suas obrigações além de contribuir com taxas especiais, as liturgias e eisforas; 3) que possuíam uma fábrica de escudos com mais de 120 escravos, (e muitas mais riquezas: moedas de 
vários lugares, ornamentos etc); 4) que Lísias e Polemarco foram presos pelos Trinta pois eram metecos ricos, sendo que o último foi executado, enquanto o primeiro conseguiu fugir $^{23}$. O discurso Contra Hippotherses, escrito não muito tempo depois da restauração democrática de 403, sobreviveu apenas como um conjunto de fragmentos encontrado em papiros egípcios, e refere-se a uma ação levada a cabo por Lísias para a recuperação de suas propriedades confiscadas pelos Trinta - Lísias aparece sempre referido na terceira pessoa, o que faz supor que, se escrito por ele, o discurso foi pronunciado por outra pessoa. Entre os dados mencionados estão: 1) Lísias e sua família possuíam 70 talentos antes do regime dos Trinta, sendo que Lísias era o mais rico dos metecos atenienses; 2) Lísias ajudou o exército democrata com 2 mil dracmas, 200 escudos, 300 mercenários mais 2 talentos de um amigo pessoal, Trasideus de Elea; 3) Lísias não foi recompensado pelos serviços prestados à democracia.

Dos textos de Platão, infere-se que Lísias e sua família atingiram certa proeminência na sociedade ateniense. Na República de Platão, Sócrates e Glauco estão no Pireu acompanhando o festival da deusa trácia Bêndis, onde são vistos por Polemarco, irmão mais velho de Lísias, que os convence a acompanhá-lo até a casa de Céfalos. Lá estavam Céfalos, Lísias e seu irmão Eutidemo, além de cidadãos, metecos e estrangeiros: é neste ambiente que Sócrates dá início ao diálogo sobre o conceito de justiça. Já no Fedro Lísias aparece como um já hábil orador que faz um discurso amoroso, o Erótico, tradicionalmente incluído no Corpus de Lísias como lys.35 discurso que, segundo Todd (2007, p. 5, n. 16) não passa de um pastiche de Platão; o diálogo faz referência à presença de Fedro em Atenas (que havia sido exilado em $415 \mathrm{e}$ dificilmente voltou antes da anistia oligárquica em 404) e a Isócrates (que nasceu c. 450 a. C.) como um menino, além de se referir a Sóflocles e Eurípides ainda vivos - ambos morreram antes da Guerra do Peloponeso, em 431. Estes dois diálogos, e o Fedro em particular, deram bastante trabalho aos estudiosos que procuraram, nestas indicações cronológicas, alguns pontos seguros da biografia de Lísias - entretanto, atualmente tende-se a não supor uma exatidão cronológica em Platão, mas pelo contrário, entender a coexistência de personagens em função tanto da discussão filosófica quanto dos

\footnotetext{
${ }^{23}$ Algumas precauções são necessárias devido à natureza retórica do discurso: associar a migração do pai a um convite de Péricles talvez se relacionasse mais à boa fama de Péricles entre os ouvintes do que a um fato incontestável; a caracterização da família como os "bons metecos" faz parte da construção do ethos do orador, atributo de Lísias celebrado entre os retóricos antigos. (TODD, 2007).
} 
possíveis debates políticos implícitos nos diálogos (WATANABE, 2001; TODD, 2007, p. 11).

No famoso discurso Contra Neaira (dem.lix), que teria sido escrito c. 340 a. C., o orador, provavelmente Apolodoros, ao tentar provar que Neaira era uma escrava, associa ela a Metaneira, uma escrava adquirida como amante por um certo "Lísias o sofista", na época em que a mãe deste ainda estava viva. Como Neaira provavelmente nasceu não muito antes de 400 a. C., e contava com menos de 12 anos na época em que Lísias tomou Metaneira, os estudiosos tendem a concordar que Lísias tomaria uma amante e teria ainda uma mãe viva não antes de 390 a. C.

Mais completas e sistemáticas são as biografias antigas conservadas. A mais recente, atribuída erroneamente a Plutarco (daí a autoria aparecer como PseudoPlutarco) contém todas as informações da mais antiga, de Dionísio de Halicarnasso, que provavelmente lhe serviu de base, e acrescenta alguns dados - a tabela abaixo contém na coluna direita as informações presentes na biografia de Dionísio de Halicarnasso, escrita no século I a. C., e na coluna esquerda aquelas que constam apenas na biografia de Pseudo-Plutarco, escrita no século I ou II d. C.

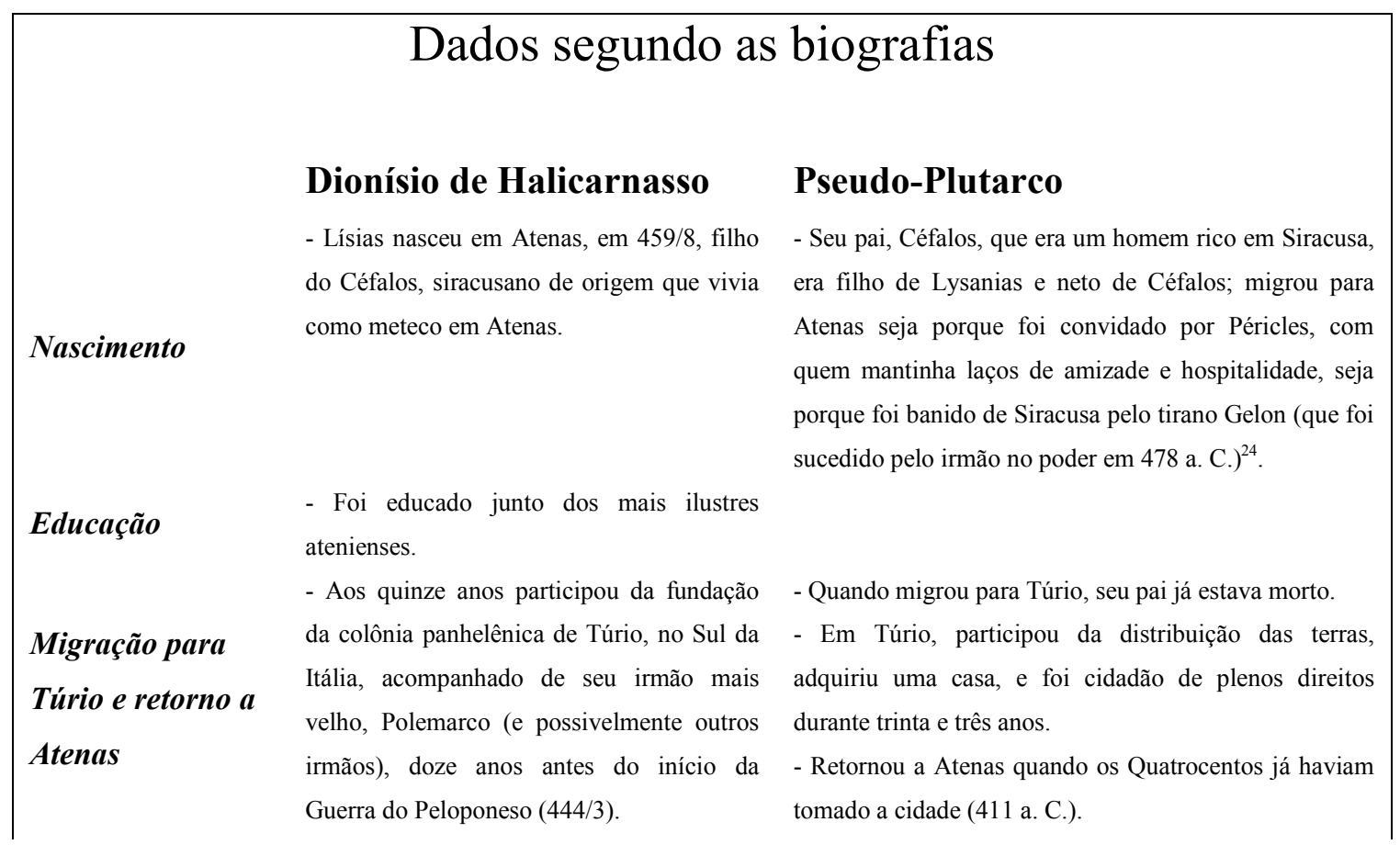

24 Todd (2007, p. 8, n. 29) observa que a referência a Gelon, se retirada por Pseudo-Plutarco de um discurso perdido de Lísias, seria um erro (talvez deliberado) deste, pois as datações mais antigas para a chegada de Céfalos em Atenas não ultrapassam o ano de 474 a. C. 


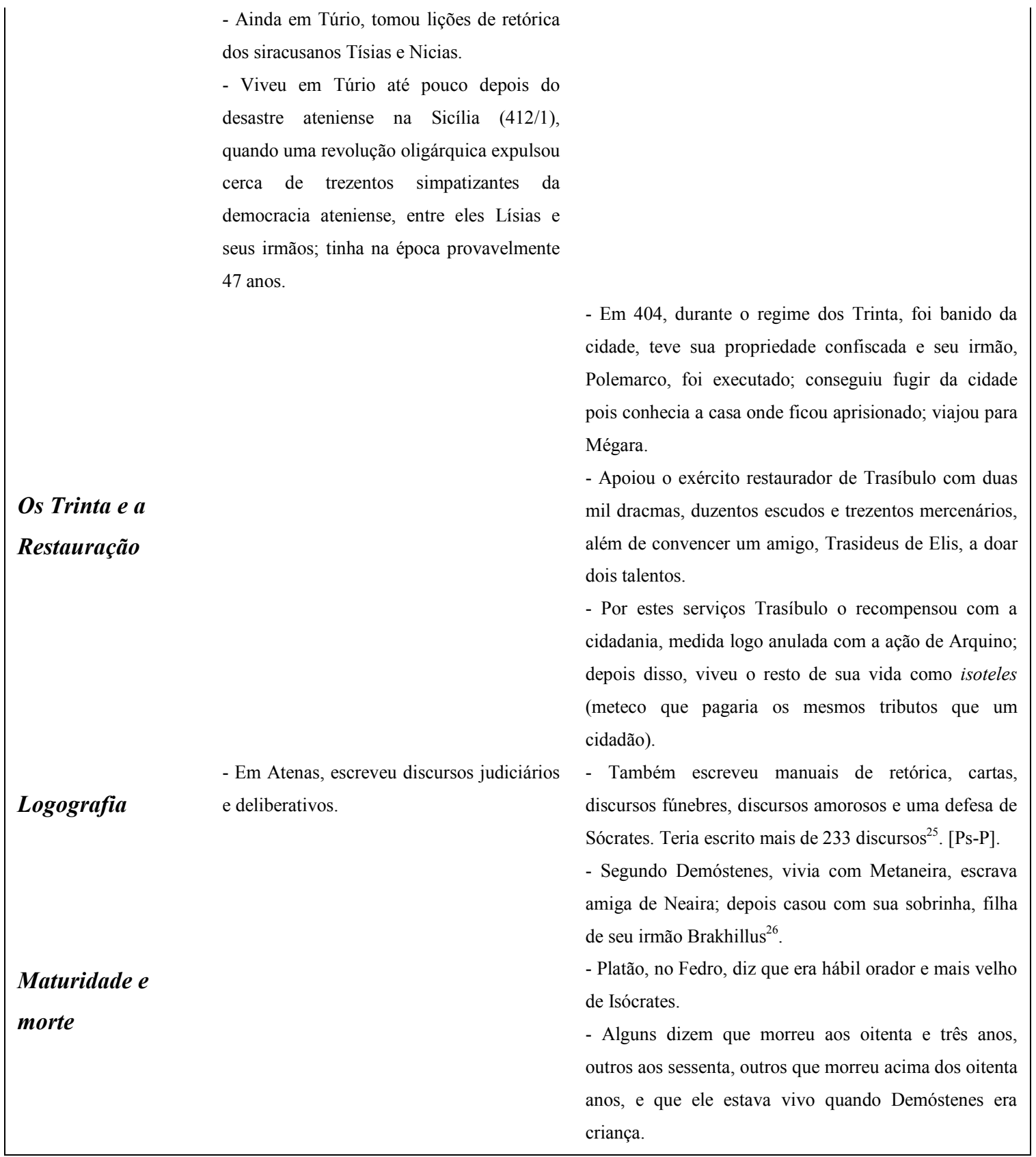

Tabela 1. Informações biográficas de Lísias segundo Dionísio de Halicarnasso e Pseudo-Plutarco

${ }^{25}$ Pseudo-Plutarco (V. Lys., 836A) afirma que, nos dias correntes (prov. Século I ou II d. C.) 425 discursos eram atribuídos à Lísias, dos quais a escola de Dionísio de Halicarnasso e Caecilios de Caleacte (século I a. C.) confirmariam a autenticidade de apenas 133 - o que, como observa Todd (2007, p. 12), faz de Lísias o mais produtivo dos oradores áticos, com uma média de 10 discursos por ano. Entretanto, o fato de que 233 discursos foram comprovados pela escola de Dionísio e Caecilios não significa nem que necessariamente eram autênticos, nem que todos os autênticos sobreviveram após três séculos de sua produção.

${ }^{26}$ Dover (1968, p. 39) nota que Pseudo-Plutarco se enganou na leitura de Demóstenes: Bracilos era seu cunhado, não irmão, e sua relação com Metaneira não foi antes do casamento com sua sobrinha. 
Provavelmente, aos autores destas biografias estava disponível uma gama muito maior de documentos do que os existentes hoje, que poderiam ir de biografias mais antigas a outros discursos autobiográficos preservados. Entretanto, os estudiosos, com base nos documentos ainda existentes, tendem a questionar dois pontos: I) as datas de nascimento e morte; II) a questão da concessão da cidadania.

I. As biografias afirmam que Lísias teria nascido em 459/8, migrado para Túrio aos quinze anos em 444, retornado a Atenas em 411 e morrido aos oitenta anos, por volta de 380. Entretanto, isso faria com que Lísias tivesse começado sua carreira de escritor somente aos 56 anos, e que tivesse tomado Metaneira como amante com quase de 80 anos, além de sua mãe ser quase centenária. Nada disso é impossível, e como afirma Carey (1989, p. 1), a atividade literária, a longevidade e a potência sexual são variáveis demais para se tornarem conclusivos. De todo modo, alguns estudiosos, como $\operatorname{Dover}^{27}$ (1968), preferem datar o nascimento de Lísias em 445 e sua migração aos quinze anos para Túrio em 430, fazendo com que ele contasse com 42 anos quando começou a escrever discursos, e 55 anos quando tomou Metaneira e sua mãe estava viva.

II. De acordo com Pseudo-Plutarco, Lísias obteve os direitos de cidadania graças a um decreto proposto por Trasíbulo logo após a vitória do exército democrata, que recompensava todos aqueles que, como escreve Aristóteles, o haviam "acompanhado em seu regresso do Pireu, alguns deles sabidamente escravos" (Constituição de Atenas, xv.2). Ainda segundo Pseudo-Plutarco, Lísias perdeu a cidadania quando o decreto de Trasíbulo foi revogado por Arquino, devido à irregularidade de não ter passado previamente pelo Conselho antes de ser votado pela Assembléia; com isso, PseudoPlutarco afirma que Lísias continuou a viver em Atenas sem direito de voto ou acesso à magistratura - segundo a historiografia, Lísias seria então um meteco privilegiado, usufruindo igualdade de impostos com os cidadãos e direito de ser proprietário de uma residência, formas comuns de homenagens a metecos (Whitehead, 1977). Daí surgem

\footnotetext{
${ }^{27}$ Que argumenta que a data de 459/8 foi estabelecida por Dionísio de Halicarnasso a partir da data de fundação de Túrio (444), mas nada diz que Lísias migrou para a colônia na sua fundação (DOVER, p. 42). Entretanto, o principal objetivo de Dover é acomodar a datação das biografias às datas dramáticas dos diálogos de Platão, o que tem sido abandonado pelos estudos atuais.
} 
duas dúvidas: a) se Lísias realmente obteve a cidadania entre o decreto de Trasíbulo e a sua anulação por Arquino; b) se Lísias nunca mais obteve a cidadania.

a) Tradicionalmente, os estudiosos de Lísias tendem a concordar com PseudoPlutarco, acrescentando que foi neste curto período em que foi cidadão que Lísias pronunciou o discurso Contra Eratóstenes. No entanto, S. Todd (2007, p. 13) levanta três questões: em primeiro lugar, posto que um decreto deixa de valer assim que um cidadão apresenta a intenção de iniciar uma graphe paranomon, ou seja, uma ação de inconstitucionalidade, como o fez Arquino - como este último não teria motivos para esperar, provavelmente o decreto de Trasíbulo foi anulado antes de ter tido algum efeito; em segundo lugar, não há certeza entre os historiadores se os metecos poderiam ou não apresentar-se em tribunal diretamente, sem o seu "patrono" (prostates), e mesmo que normalmente não lhes fosse permitido, o julgamento de um dos Trinta poderia ter sido considerado um caso especial; em terceiro lugar, o discurso pode não ter sido pronunciado, tendo sido apenas escrito por Lísias como um panfleto, de modo a contribuir para a condenação de Eratóstenes e também divulgar sua própria visão sobre a anistia e sobre a política ateniense - o subtítulo do discurso como aparece no manuscrito Palatinus 88, "pronunciado pelo próprio Lísias", poderia ter sido uma inferência do copista a partir do texto, e não um dado de que ele teria sido realmente pronunciado. Sendo assim, não é necessário que Lísias tivesse obtido a cidadania para que o discurso fosse pronunciado, ou ao menos publicado.

b) Um decreto gravado em pedra, encontrado na Acrópole em 1884, e datado de 401/0 a. C., parece contradizer o biógrafo: trata-se de um decreto de um certo Arquino, provavelmente o mesmo que revogou o decreto de Trasíbulo, que concedia benefícios aos metecos divididos, segundo a restauração de M. J. Osborne (1981-3, D6) em três categorias: I. os que participaram do retorno à File; II. os que participaram da batalha de Muníquia e III. os que permaneceram no Pireu com o demos, diante provavelmente do ataque do rei espartano Pausânias, durante o processo da restauração de 403 a. C. Aos da primeira categoria, concedia-se a cidadania plena; aos da segunda e terceira, apenas a igualdade fiscal (isotelia). O historiador Luciano Canfora (1987, p. 683) acredita que não há motivo para que Lísias não tenha recebido a cidadania com este decreto, posto que ele participou ativamente da restauração desde o início. Mas por que isso não teria sido mencionado nas biografias? A narrativa do decreto de Trasíbulo e de sua revogação encontra-se em textos de Aristóteles, Xenofonte e Esquines, aos quais os biógrafos 
provavelmente tiveram acesso - pode-se supor que o decreto de 401/0 a. C. não tenha sido relatado nas fontes, impedindo assim uma inferência positiva para a cidadania de Lísias. Contudo, S. Todd (2007, p. 14-5) é mais cauteloso que L. Canfora: em primeiro lugar, a restauração epigráfica do decreto ainda está aberta a diversas interpretações; em segundo lugar, o fragmento Contra Hippoterses enfatiza a contribuição financeira e logística de Lísias à restauração, sem fazer qualquer menção a uma participação militar; em terceiro lugar, no mesmo discurso, o orador afirma que Lísias cogitou retornar do exílio logo que os democratas ocuparam o Pireu, indicando assim que Lísias não participou da tomada do porto. Por tudo isso, S. Todd tende a concordar com o biógrafo anônimo que Lísias não obteve mais a cidadania após a revogação do decreto de Trasíbulo, em 403 a. C.

\section{Estilo e retórica}

Lísias ocupa uma posição especial na história da retórica grega. Tradicionalmente um dos Dez Oradores Áticos ${ }^{28}$, pertence ao que se convencionou chamar de reação ao estilo grandiloqüente de Górgias. Este, nascido em Leontini (atual Lentini) na Sicília, no início do século V a. C., é considerado um dos introdutores da retórica em Atenas, além de ser associado às primeiras articulações entre a retórica e a literatura, até então limitada à prática judiciária e à dialética sofística. $\mathrm{O}$ estilo "gorgiânico" é marcado pela ornamentação e multiplicação de figuras, seja de palavras (assonâncias, rimas, paronomásias) ou de pensamento (perífrases, metáforas, antíteses): Górgias, segundo L. Pernot, visava rivalizar a retórica com a poesia, compensando, com os efeitos de estilo, a ausência de métrica e acompanhamento musical (2000, p. 33).

A reação ao estilo grandioso e ornado de Górgias se deu em grande parte pela utilização da retórica nos âmbito judiciário, em particular com a logografia, ou seja, a prática pela qual um profissional era pago para escrever um discurso que seu cliente

\footnotetext{
28 A lista completa inclui Antifonte, Andócides, o próprio Lísias, Isócrates, Isaeu, Esquines, Licurgo, Demóstenes, Hipérides e Dinarco. De provável origem alexandrina (é impossível de datar com precisão sua composição inicial), aparece pela primeira vez como cânone na crítica de Caecilius de Kaleacte, hoje perdida, composta no século I a. C. Segundo L. Pernot (2000, pp. 57-9), considerando que a lista consta apenas de oradores que ou eram atenienses ou produziram em Atenas, acredita que o cânone significa uma tomada de partido em nome do "momento ateniense" da retórica e de valorização do dialeto ático.
} 
pronunciaria como se fosse escrito por ele mesmo. Neste ponto, a retórica se encontrava em uma posição paradoxal: se por um lado a boa retórica era valorizada em Atenas, a opinião pública desaprovava a logografia (CAREY, 1989). Assim, era necessário que o logógrafo se anulasse na escrita em nome da plausibilidade de que o discurso foi escrito pelo próprio orador. Se o primeiro logógrafo conhecido, Antifonte, ainda seguia o estilo gorgiânico, será com Lísias que se iniciará o esforço do logógrafo na direção da clareza e da simplicidade, sempre adaptadas ao cliente.

C. Carey (1989, pp. 7-11), dialogando tanto com Dionísio de Halicarnasso quanto com os estudiosos modernos, enumera alguma das características do estilo presente nos discursos (autênticos ou não) de Lísias:

- escolha das palavras e expressões: utilização do idioma comum falado na Ática; raro uso de expressões poéticas ou inusuais; economia no uso de metáforas;

- construção da frase: abandono da ornamentação da frase $^{29}$; uso freqüente de antíteses; uso, no proêmio, do "estilo periódico" (disposição dos pensamentos em sentenças longas, cada uma expressando um nexo lógico de idéias); técnicas de plausibilidade nas narrativas, seja pelo estilo coloquial (simulando uma ausência de artifício), seja pelo "período histórico" (frases subordinadas ou coordenadas ligadas a uma sentença anterior).

- disposição das partes do discurso: manutenção das partes tradicionais (proêmio, narrativa, prova e conclusão), eventualmente mesclando narrativa e prova; na narrativa, ausência aparente de estilo (incluindo inadequações gramaticais e anacolutos, para transmitir uma imagem de sinceridade) e economia de detalhes (de modo a não interromper o progresso da narrativa); grande variedade de proêmios, adaptados sempre aos casos; habilidade na disposição de leis e testemunhos no discurso; ênfase na configuração do caráter (ethos) do orador e seu oponente; utilização da emotividade (pathos) conduzindo o auditório a sentir determinadas emoções pela narrativa mais do que por apelos intensos.

\footnotetext{
${ }^{29} \mathrm{O}$ autor não adere completamente à tradição de afirmar a simplicidade absoluta de Lísias, enumenrando algumas figuras recorrentes, como o uso de sinônimos como ênfase e a preocupação com o balanceamento da sentença, usando palavras não vitais para o sentido; assim, a própria impressão de ausência de arte seria parte do estilo de Lísias.
} 


\section{Transmissão dos textos}

Como de costume na história da transmissão dos textos clássicos, do momento em que os discursos de Lísias foram escritos e divulgados em Atenas até sua recepção nos estudos atuais, não são poucas as lacunas e sombras. Os textos atribuídos a Lísias estão espalhados, segundo se acredita (RONCALI, 1969; CAREY, 2007), em cerca de 50 manuscritos e centenas de fragmentos de papiros, que contém textos que vão de discursos completos a linhas dispersas.

Dos manuscritos, o mais antigo é o Marcianus Graecus 416 (coll. 536), datado do século XI d. C., que contém somente o discurso Lys.2. Entretanto, o mais completo é o Palatinus Graecus 88, de Heidelberg, datado do século XII d. C., que contém os discursos Lys.1-31, dos quais 23 estão completos. Sobre a produção do Palatinus 88, sabe-se que foi copiado por um escriba chamado Theodoros, mas mudanças na grafia indicam que outros três copistas participaram; uma anotação indica que o manuscrito estava em Nicéia, hoje Ísnik na Turquia (e capital provisória do Império Bizantino após o saque de Constantinopla em 1204), o que leva S. Todd (2007, p. 19) a pensar que ele foi produzido por estudiosos bizantinos, antes de ser levado para Heidelberg, na atual Alemanha. De acordo com K. Dover (1968, p. 1), o manuscrito divide-se em 3 partes desiguais:

1. Dois discursos de Lísias, dois de Antístenes e um de Demades.

2. Vinte e nove discursos de Lísias (no índice do copista são listados 30, mas um se perdeu devido aos danos do manuscrito, junto de porções de quatro outros).

\section{Helena, de Górgias.}

Esta disposição deu origem à atual numeração dos discursos: os dois discursos tornaram-se I e II, enquanto que os vinte e nove da segunda parte são numerados como III-XXXI. Quando à ordenação dos discursos no manuscrito, os estudiosos têm sugerido diversos critérios: a ordenação alfabética por título; a popularidade dos discursos; a afinidade temática, de períodos, de procedimento jurídico dos casos em questão; no entanto, diversos discursos "furariam" estes critérios, criando descontinuidades incompreensíveis (TODD, 2007, pp. 20-25).

A partir do Palatinus 88 foram feitos diversos outros manuscritos, em sua maioria datados do século XV. Destes, provavelmente, foi feita a editio princeps das 
obras de Lísias no ano de 1513, em Veneza, pelo humanista italiano Aldus Pius Manutius, que daria início a uma série reedições, seja sob o impulso da retórica entre os séculos XVI-XVIII, seja com o amplo movimento de crítica documental do século XIX.

Fundamentais na ampliação do Corpus Lysiacum foram as descobertas arqueológicas realizadas no Egito no início do século XX, que trouxeram uma grande quantidade de fragmentos da obra atribuída a Lísias escrita em diversos papiros, conservados, dentre outros fatores, pelo clima seco da região. De acordo com o levantamento feito por M. Cocurullo (2001), o papiro mais antigo é o P. Hibeh 14, encontrado na cidade egípcia de El Hibeh (antiga Teudjoi egípcia e Ankyronpolis grega) como parte da cartonnage de uma múmia, datado do século III a. C., contém 22 fragmentos, sendo que somente os três primeiros são associados a um discurso (Contra Teozodites, encontrado em outros papiros). Sem dúvida, o papiro mais importante é o $P$. Oxyrhincus XIII 1606, encontrado em um monte de lixo coberto de areia, na cidade egípcia de El-Bahnasa (antiga Pr-Medjed egípcia e Oxyrhynchus grega, ao sudoeste de El-Hibah), que contém 155 fragmentos: os primeiros, parte de um discurso intitulado Contra Hipotherses, refere-se a um caso envolvendo o próprio Lísias, contendo, junto ao Lys.12, preciosas informações biográficas. A edição mais recente do Corpus, que incorpora tanto os discursos tradicionalmente editados quanto os fragmentos recématribuídos, é a Lysiae Orationes cum Fragmentis, de Christopher Carey, publicada pela Oxford University Press em 2007.

Muitos estudiosos procuraram critérios para a seleção dos discursos presentes tanto no Palatinus 88 quanto nos outros manuscritos e nos papiros egípcios. Gernet e Bizos (1955) sugerem, a partir de fontes antigas, a existência de uma "colletion primitive" integral das obras de Lísias, corretamente atribuídas ou não, e que a este Corpus tiveram acesso os estudiosos antigos de Lísias, como Dionísio de Halicarnasso; entretanto, não se pode dizer com certeza que este corpus tenha sido a base para a composição do Palatinus 88 , e nem mesmo que este corpus realmente existiu. É sugestivo que Stephen C. Todd, após discutir a (in)aplicabilidade destes critérios, acabe por enfatizar o papel do acaso na explicação da preservação dos discursos (2007, p. 25).

\section{Autoria}

Muito mais delicada, no entanto, é a questão da autoria. O debate sobre a autenticidade dos discursos atribuídos a Lísias recua até o século I a. C., quando 
Dionísio de Halicarnasso questionava algumas atribuições feitas por Calimaco, poeta helenístico que teria sido livreiro em Alexandria durante a segunda metade do século III a. C., e enquanto tal realizou uma atribuição de autoria para centenas de discursos áticos (TODD, 2007, p. 26). De todo modo, apesar de que a recente edição de Carey (2007) aumente significativamente o Corpus pela inclusão de novos fragmentos, é possível perceber uma direção inversa quanto à autenticidade dos discursos: enquanto novos textos entram para o Corpus, antigos textos deixam de ser considerados genuínos.

Um dos clássicos sobre a questão da autoria é a obra de K. Dover, Lysias and the Corpus Lysiacum (1968), na qual o autor apresenta os resultados de vários testes de autenticidade aos discursos de Lísias, em especial o chamado teste estilométrico (a partir da repetição de certas formas verbais, da ordenação da frase, do uso de artigos e particular em determinado caso, a reiteração de "erros" gramaticais etc), chegando à conclusão de que não é possível, por meio de qualquer teste lingüístico, obter a garantia de autenticidade dos discursos - exceto pelo discurso Contra Eratóstenes (lys.12), que apresenta Lísias falando em primeira pessoa. Ao lado das disparidades estilométricas, estão as questões do relacionamento entre cliente e logógrafo (DOVER, 1968, pp. 148174; USHER, 1976), que acabam por embaralhar qualquer possibilidade de busca de uma autoria autêntica de Lísias nos discursos do Corpus.

Não sem ironia, em comentário ao estudo de K. Dover, T. Winter escrevia em 1974:

Da época clássica até o presente, acadêmicos têm rejeitado os discursos de Lísias. Seus esforços agora estão completos. Na época de Dionísio de Halicarnasso o corpus lisiano incluía 425 discursos. Destes, Dionísio afirmava que "não menos do que 200" orações jurídicas eram o trabalho de Lísias. Incluindo alguns discursos não-jurídicos, ele conclui que um total de 230 eram trabalhos genuínos. O fator acadêmico e os usuais acidentes de transmissão ns deixaram somente trinta e cinco. Isto inclui duas epítomes (orações 11 e 15), três citações extensivas no De Lysia ludicium (rações 32, 33 e 34) e o Eroticus do Fedro de Platão. Em 1968, somente seis orações (1, 3, 21, 26, 32 e 34) permaneciam livres da ofensiva dos estudiosos. Mas agora o corpus sobrevivente inteiro está avariado, pois Kenneth Dover concluiu que somente a oração 12 (a qual foi questionada por Alphonse Hecker em 1847) pode garantidamente ser chamada de genuína. (WINTER, 1974). 
É nesta área de indefinição, quanto à autoria, que se encontram os discursos do chamado Corpus Lysiacum. Como então promover um estudo histórico a partir dos discursos? Em que medida os discursos de Lísias são documentos históricos? A seguir, discutiremos esta questão a partir da abordagem desenvolvida por S. C. Todd.

\section{b) Os discursos como documentos históricos}

O uso dos discursos de Lísias tem uma história própria: se por um lado foi base de comportados comentários estilísticos dirigidos ao (restrito) público acadêmico, como as diversas coletâneas publicadas desde o século XIX até os dias atuais, por outro deu origem a textos de inserção política imediata. Deste último grupo, vale citar dois exemplos: o primeiro é a tradução francesa do discurso Contra Eratóstenes de Lísias por Dupont de Nemours, publicado entre 1794-5, sob o título de Lysias, Plaidoyer contre les membres des anciens Comités de Salut Public et de Sûreté Générale (citado em TODD, 2007, p. 34, n. 130); o segundo é o livro de Friedrich Ferckel, publicado em 1937 na Alemanha, que era dedicado à crítica do uso de Lísias nas escolas: segundo seu autor, ler Lísias (um meteco) falando sobre os heróis da história ateniense, era como ouvir um judeu falando do Kaiser Guilherme (citado em TODD, 1990, p. 163).

Das diversas questões que surgem da história da utilização dos discursos de Lísias, reteremos aqui aquelas relativas à abordagem historiográfica aos discursos: seriam eles uma fonte histórica adequada? Como equacionar seu caráter retórico com uma mínima veracidade de eventos mencionados? O que é possível saber a partir da leitura histórica dos discursos? Um dos textos mais fecundos sobre estas questões é o artigo metodológico de S. C. Todd (1990), que trata não somente dos discursos de Lísias mas dos oradores áticos em geral, intitulado The Use and Abuse of Attic Orators $^{30}$. Não sem um tom abertamente polêmico, como o próprio título indica, o autor

\footnotetext{
${ }^{30} \mathrm{O}$ autor deste texto, Stephen C. Todd, tem se tornado nos últimos anos um dos principais estudiosos dos oradores áticos e do direito grego em língua inglesa, e em particular dos discursos de Lísias. Além de uma nova tradução, publicada em 2000, de todos os discursos e fragmentos de Lísias para o inglês, S. Todd publicou em 2007 o primeiro volume de uma prometida série de estudos sobre os discursos de Lísias, $A$ Commentary on Lysias: Speeches 1-11, editado pela Oxford University Press. Neste volume, de quase
} 
faz um triplo movimento ao expor (1) uma breve história do uso dos discursos oradores, (2) uma proposição de questões metodológicas mais gerais para a análise dos discursos e (3) a discussão de questões mais específicas, onde são feitas críticas a algumas soluções que o autor considera insuficientes. Dada a relevância deste texto para o presente trabalho, perseguiremos brevemente seu percurso, para em seguida apresentarmos algumas questões próprias.

\section{O uso e o abuso dos oradores áticos segundo S. C. Todd}

Se os discursos dos oradores áticos são uma fundamental fonte para o estudo da história social, econômica, legal e política de Atenas no período clássico, por que eles têm recebido (ao menos até a década de 1990) pouca atenção de classicistas e historiadores? Na primeira parte do texto, Todd (1990, p. 160) argumenta que a negligência quanto aos discursos se deve ao declínio no status e respeitabilidade dos discursos nos currículos escolares europeu nos séculos XIX e XX. Para o autor, durante a maior parte do século XIX, os discursos eram vistos como modelos para a formação intelectual e política do homem cultivado, particularmente na Inglaterra e na Alemanha; quanto à História, os discursos eram vistos como documentos diretos dos acontecimentos - eventuais discordâncias narrativas dos discursos entre si e com outras fontes, como Tucídides, Xenofonte ou Aristóteles, eram vistas como erros de atribuição de autoria, não como diferentes visões ou mesmo mentira de uma das fontes.

Isso mudaria a partir de aproximadamente 1870, quando estudiosos alemães começam a analisar o caráter retórico dos discursos, o que acabaria resultando na completa desconfiança: os oradores passariam de fontes confiáveis a "advogados mentirosos". Assim, ao mesmo tempo em que a validade da retórica na formação moral é questionada as afirmações dos oradores se tornam duvidosas - sua posição no currículo escolar passa a ser combatida, restando aos discursos a leitura dos especialistas em retórica, preocupados somente com as questões estilísticas. O autor, finalmente, observa um retorno da validade dos oradores a partir da década de 1960,

800 páginas, além de introdução, texto bilíngüe (grego-inglês) e subseqüente comentário a cada discurso, o autor faz na General Introduction um importante levantamento das principais questões relativas aos discursos do Corpus, fundamental para o desenvolvimento do presente trabalho. 
arriscando três hipóteses: o aparecimento de estudos sobre o direito ateniense; o aumento do número de estudantes, gerando a necessidade de autores de prosa simples no contexto universitário; a constatação de que a juventude já está corrompida, e portanto a retórica não faria muita diferença. (TODD, 1990, pp. 160-3).

Na segunda parte do texto, caracterizando os discursos dos oradores áticos como de uma "sofisticação incomum", Todd (1990, pp. 164-7) elabora uma proposta metodológica segundo a qual a análise dos discursos deve diferenciar três níveis: 1) o discurso pronunciado: marcações de tempo e espaço de quando teria sido pronunciado, circunstâncias institucionais; 2) o discurso publicado: fidelidade em relação ao original, autenticidade (foi realmente pronunciado, ou é um peça literária, um panfleto?), pressões sobre o orador na revisão do texto, a circulação do discurso etc; 3) o discurso preservado: quais as razões para a preservação, a quais usos se prestou o texto etc. Deste modo, o autor acaba por deslocar a ênfase da análise, até então concentrada na questão da autoria (pouco importante para o historiador) para a questão da autenticidade do discurso como fato social.

Todd então parte, na terceira e última parte de seu texto (1990, pp. 168-75), para as questões mais concretas postas pelos discursos: data, lugar, meio social, e as mais complexas relações entre típico/anormal e fato/ficção. Quanto às primeiras, apesar de incertezas nos detalhes, alguns pontos são aceitos: todos os discursos foram produzidos entre 420 e 320 a. C.; de todos os discursos dos oradores, apenas um (Isoc.29) não foi escrito para ser pronunciado em Atenas; e em geral, os oradores pertenciam à elite ateniense (principalmente os que podiam pagar um logógrafo). Já as duas últimas são mais complexas.

A questão do "típico/anormal": certas afirmações são registradas porque são típicas ou porque são anormais? Até que ponto é possível generalizar uma afirmação e, partir desta generalização, alcançar uma prática social regular? De início, a natureza social dos discursos, restritos em sua ampla maioria aos atenienses ricos, corrobora para se pensar em fatos anormais. A sugestão de Todd é que o estudo do quadro jurídico no qual se insere o discurso é fundamental para abordar estas questões. Por exemplo: dentre os discursos dos oradores, 15 mencionam casos de propriedade, sendo que em 3 não aparece propriedade da terra - seria um indício de que $20 \%$ dos atenienses ricos não possuíam riqueza fundiária? Não, segundo o autor: em primeiro lugar, porque os discursos não apresentam de modo algum uma amostragem que permitisse uma 
estatística; em segundo lugar, haviam diversas dificuldades legais e riscos efetivos na conversão da riqueza imóvel em móvel (dinheiro ou bens), os quais, ao lado da valorização social da riqueza fundiária, seriam fatores que impediriam que tal prática fosse disseminada entre os atenienses ricos.

A questão fato/ficção: existe meio termo entre a confiança e a desconfiança absolutas? Todd critica algumas das soluções apresentadas pela historiografia contemporânea, dentre as quais destacam-se: 1) "se os argumentos são fracos, o orador inventa os fatos" - mas o que impediria o orador de fazê-lo mesmo num bom caso com bons argumentos? 2) "o júri não era estúpido para acreditar em certos exageros dos oradores" - mas, considerando que os julgamentos se tratavam de um embate retórico mais do que uma pesquisa em busca da verdade, que o público ateniense era admirador das habilidades retóricas, e que o júri poderia acreditar sem necessariamente fundar suas opiniões na lógica, tudo isso invalida a presunção de "racionalidade" do júri; 3) "a repetição de acusações significa que certas atitudes ilegais eram comuns, como a corrupção" - mas, pensando na lógica da democracia, na qual o povo não revê suas decisões e não admite seus erros, a acusação de corrupção era um modo do demos isentar-se da responsabilidade por más decisões coletivas por meio da punição de indivíduos, sendo a corrupção uma acusação padrão para isso; 4) "as afirmações feitas de passagem, que não beneficiam diretamente o caso, seriam mais verossímeis que aquelas que são fundamentais para a argumentação" - entretanto, como ter certeza que tais afirmações não colaboram com a causa? Uma indicação do autor, que complementaria esta última solução, seria de que a análise e explicação do fundo legal e das técnicas retóricas permitiriam um melhor discernimento entre as afirmações úteis e inúteis. Daí terminar o texto afirmando a necessidade da publicação de bons comentários históricos, legais e literários dos discursos dos oradores áticos - coisa que, 17 anos depois, o próprio autor faria no caso do Corpus de Lísias.

\section{Tensões e diálogos}

Após este percurso, fica destacado o caráter inovador da abordagem de S. Todd ao deixar em segundo plano os debates infindáveis sobre a autoria dos discursos; como vai dizer em outro momento, é fundamental procurar as "atitudes e percepções no tempo da escrita", qualquer que fosse a autoria (TODD, 2000, p. 9). De qualquer maneira, 
acredito que é possível levantar algumas objeções ao modo como o autor discutiu a questão dos discursos como fonte histórica.

Em primeiro lugar, S. Todd orienta sua investigação na direção da norma, do padrão, das regularidades de práticas e representações, na medida em que isto conduziria a uma visão mais segura da sociedade ateniense. Entretanto, esta ênfase na norma deixa de lado as tensões e desvios de representações que são encontrados nos discursos, e que são tão importantes quanto as regularidades: como será analisado no devido momento, em alguns discursos existe o choque de valores e a manipulação destes em uma direção que seja proveitosa para o caso, mesmo que entre em choque com os valores compartilhados - se por um lado, por meio da análise desse choque seja possível determinar o próprio padrão, por outro é igualmente possível analisar estes movimentos retóricos como parte de estratégias de inserção ou exclusão social de grupos específicos, como os metecos. Restringir-se à análise de regras e exceções levaria a uma enumeração de direitos e deveres, mas deixaria em um ponto cego o movimento mesmo de ressignificação que determinados grupos realizam no campo das representações e que podem ser observados nos discursos, que não se fecham em si, mas que são atravessados por argumentos e valores produzidos socialmente. Em suma: mais do que confrontar regras e exceções, é o caso de se analisar a inserção social das tensões entre representações (argumentos e valores retóricos) presentes nos discursos como fatos sociais passíveis de interpretação: a tensão discursiva se torna uma informação para a história social.

Em segundo lugar, e mais importante, parece que o autor procura algo que está por trás dos textos: os eventos históricos, o sistema jurídico, as práticas cotidianas. Se por um lado este procedimento, aliás típico da historiografia inglesa em sua discussão das "evidências", é fundamental para o conhecimento histórico, por outro certamente não o esgota: limitar-se aos dados objetivos que estão por trás dos textos acaba por negligenciar o diálogo entre as concepções do historiador e aquelas presentes nos discursos, fazendo com que determinadas interpretações apareçam na análise sob a forma de dados objetivos. Um exemplo está na discussão que o autor faz em seu manual sobre direito ateniense, The Shape of Athenian Law (TODD, 1993), a respeito da natureza política dos embates judiciais: o autor afirma que em Atenas "um caso necessariamente assume tons políticos no momento em que envolve uma confrontação entre litigantes que são politicamente ativos" (p. 155), e cita diversos exemplos nos 
quais o direito foi usado como uma "arena alternativa" à política (p. 158). Mas como o autor entende o sentido do termo "política"? Destas passagens, fica a impressão de que a política se restringe à disputa entre "políticos": assim, uma acusação pública pela inconstitucionalidade de uma premiação, como a de Ésquines no discurso Sobre a Coroa, se torna política somente porque envolvia Demóstenes, inimigo político de Ésquines. Mas por que limitar a política à ação dos políticos? A política, em Atenas ou mesmo nos dias atuais, é um monopólio dos políticos? O autor não se faz esta pergunta, e acaba, assim, por elencar os conflitos políticos (ou seja, entre políticos) nos tribunais para argumentar que o direito ateniense era diferente do direito moderno onde existe a separação dos poderes. Desse modo, a construção de memórias e teorias políticas nos tribunais, as reflexões sobre os modos ideais de conduta de habitantes da polis e o sempre enfatizado caráter exemplar das sentenças não seriam, na abordagem de Todd, parte da política - esta, somente quando houvesse políticos em litígio. Dito isto, fica então a potência da discussão hermenêutica na análise e interpretação dos discursos: colocar em diálogo as concepções e valores presentes nos textos com aqueles do próprio historiador significaria uma reorientação nas questões postas ao passado - de uma atitude de detetive, inevitavelmente queixoso pela falta de evidências, o historiador assumiria uma postura propriamente reflexiva, posto que é tão sujeito quanto objeto do conhecimento.

\section{c) Retórica, direito e democracia}

\section{A Retórica e a polis}

É um lugar comum afirmar a importância da retórica para a democracia ateniense, ou até mais do que isso: Jean-Pierre Vernant, por exemplo, fazia na década de 1970 da preeminência da palavra um dos fundamentos da polis em geral:

A palavra [na polis clássica] não é mais o termo ritual, a fórmula justa, mas o debate contraditório, a discussão, a argumentação. Supõe um público ao qual ela se dirige como a um juiz que decide em última instância, de mãos erguidas, entre os dois partidos que lhe são apresentados; é essa escolha puramente humana que mede a força de persuasão respectiva dos dois discursos, assegurando a vitória de um dos oradores sobre seu adversário. Todas as questões de interesse geral que o Soberano 
tinha por função regularizar e que definem o campo da arché são agora submetidas à arte retórica e deverão resolver-se na conclusão de um debate [...]. Entre a política e o $\operatorname{logos}$, há assim uma relação estreita, vínculo recíproco. A arte política é essencialmente exercício da linguagem; e o logos, na origem, toma consciência de si mesmo, de suas regras, de sua eficácia, através de sua função política”. (1972, p. 35)

Quanto à Assembléia democrática, não são poucos os historiadores e classicistas que enfatizaram a importância da retórica. C. Carey, por exemplo, ressalta dois aspectos da Assembléia ateniense em sua relação com a retórica: em primeiro lugar, de acordo com o próprio funcionamento institucional, o grande número de cidadãos que, reunidos, eram responsáveis pela aprovação de leis e pela definição de políticas em todas as áreas, criaria um grande escopo para a manipulação por um hábil orador; em segundo lugar, no final do quinto século a experiência militar e o pertencimento a famílias aristocráticas deixam de ser atributos indispensáveis dos líderes políticos, abrindo maior espaço para a habilidade retórica; em terceiro lugar, a penetração dos sofistas entre os jovens com ambições políticas é um indício da centralidade da retórica na política (CAREY, 1989, p. 4).

\section{Retórica e direito em Atenas}

Mas, sem dúvida, é no âmbito jurídico que a retórica encontra seu espaço mais tradicional: assim como a própria origem da retórica é associada às disputas judiciais siracusanas no final do século VI e início do V a. C., a grande maioria dos discursos retóricos preservados foram escritos visando sua execução em tribunal. O próprio funcionamento institucional do sistema jurídico ateniense garantia esta centralidade, naquilo que se convencionou chamar o "amadorismo do direito grego", quando comparado à "racionalidade" do direito romano ou dos sistemas jurídicos contemporâneos ${ }^{31}$.

Dentre os principais aspectos deste "amadorismo", tal como listados em S. Todd (1993), figuram: a ausência da figura de um juiz ou advogados, pois são os litigantes

\footnotetext{
${ }^{31}$ Neste sentido, por exemplo, S. Todd fala em "primitividade" do direito grego (1993, p. 64). A crítica à suposta racionalidade do direito moderno, como reconhece H. Yunis (2005, p. 194, n. 6), ainda não foi incorporada aos estudos sobre o direito ateniense.
} 
que iniciam o processo, discursam e interpretam a lei, sem qualquer supervisão técnica ou autoridade superior; o grande número de jurados, cerca de 500 cidadãos em média, que, sem qualquer treinamento específico na lei, davam o veredicto pelo voto da maioria sem discussão prévia nem justificativa; a curta duração, que geralmente não duravam mais que um dia, independentemente da importância da questão; a ausência de uma sistematização completa da legislação; a primazia do procedimento sobre a substância, ou seja, mais importante que um direito, era o modo pelo qual se conduziria um processo; a ausência de registros de decisões judiciais que informariam decisões subseqüentes; a ausência de uma promotoria pública, fazendo com que mesmo processos relativos à administração da polis tivessem de ser iniciados em nome de indivíduos; a ausência de inquirição ou exame cruzado de testemunhos, que cumpriam apenas a função restrita de confirmação das narrativas; a ausência de hierarquia entre as cortes, agrupadas de acordo com as competências, o que impossibilitava qualquer tipo de apelação; etc.

Todos estes aspectos propriamente institucionais fizeram com que o julgamento ateniense fosse caracterizado como uma "disputa retórica", na qual não haveria freios para a mentira dos oradores (YUNIS, 2005), ou mesmo que o julgamento fosse aproximado ao teatro (TODD, 2005; ALLEN, 2005). Neste sentido, um bom discurso era fundamental nas disputas, e o bom orador estava naturalmente em vantagem.

Entretanto, para aqueles que não possuíam boa retórica mas poderiam pagar por uma, surgiu a logografia: literalmente "escrita de discursos", era uma prática na qual um litigante contratava um especialista em retórica para escrever ou orientá-lo na escrita de um discurso.

\section{A logografia}

Iniciada na segunda metade do século $\mathrm{V}$ em Atenas, segundo a tradição por Antiphon (Carey, 1989, p. 7), a logografia possui um caráter paradoxal na democracia ateniense: se por um lado o amadorismo jurídico ateniense é uma expressão da própria democracia, na qual qualquer cidadão pode e deve conduzir um processo de modo independente (e qualquer suspeita de profissionalismo deporia contra o orador), por outro lado o belo discurso era extremamente valorizado pela sociedade ateniense, como prova a divulgação dos textos dos oradores. Este paradoxo fazia com que a logografia 
apresentasse dois momentos distintos: durante o processo, o logógrafo deve esconder-se atrás do discurso, utilizando para isso inclusive recursos retóricos, como a sensação de "falta de arte" artisticamente criada; depois do processo, o discurso, provavelmente depois de ser revisto pelo autor, era publicado e divulgado (CAREY, 1989, p. 6).

Neste sentido, a logografia tinha caráter positivo ou negativo? Para S. Todd, o exercício da logografia trazia riscos para a reputação de um cidadão que visasse a carreira pública:

Grande número de oradores, incluindo por exemplo Andocides, Ésquines e possivelmente Licurgo, eram retóricos amadores no sentido de que eles não são conhecidos por ter escrito discursos para quaisquer pessoas pronunciarem, e Ésquines em particular tem grande prazer em atacar Demóstenes como um logógrafo; correspondentemente, Demóstenes quando pretendente a se tornar líder político, e talvez também Isócrates como um educador, estavam evidentemente interessados em começar suas carreiras como oradores logográficos. Mas não existe nenhum traço de vegonha sentida por aqueles que não aspiravam a uma carreira pública (incluindo decerto três oradores metecos, Lísias, Iseu e Dinarco) - nem também nos fragmentos de Hipérides, embora a perda de muito de seu trabalho deixa a inferência aqui menos que segura. (TODD, 2005, p. 102).

O autor, portanto, faz uma separação entre aqueles que seriam prejudicados pela atividade logografia, cidadãos com aspirações políticas, e aqueles que não, os que não queriam ou mesmo não podiam (metecos) ter tais aspirações. A logografia estaria relacionada com a política de um modo negativo, no âmbito da carreira, da trajetória pessoal do "político": mas esta negatividade esgotaria as relações entre logografia e política? Decerto, a logografia, na medida em que funcionava como argumento de depreciação do adversário (Ésquines contra Demóstenes), possuía uma dimensão ética negativa; mas por outro lado, os argumentos engajados nos discursos, escritos ou não por cidadãos, eram inseridos nos debates políticos realizados seja na assembléia ou nos tribunais - os discursos eram peças que afirmavam e questionavam valores políticos, e a logografia pode ser interpretada como uma de participação política dos não-cidadãos, especialmente os metecos. Os estudos sobre a logografia tenderam a enfatizar as relações entre a logografia e a carreira política, ou entre o logógrafo e o cliente, mas acabou negligenciando o aspecto político presente no próprio ato de escrever discursos que veiculariam valores políticos e que seriam proferidos em ambientes públicos. A 
relação entre logografia e participação política nos leva ao tema, mais geral, das relações entre direito e política na Atenas Clássica.

\section{Direito e política}

O historiador dinamarquês M. H. Hansen (1990) discute estas relações em um texto intitulado The Political Powers of the People's Court in Fourth Century Athens, no qual ele argumenta que as "cortes populares" (dikasteria) não se misturam com a Assembléia (ekklesia), mas isso não impede que elas exerçam poderes políticos.

Assim, para Hansen, existem diversos indícios de que os atenienses percebiam os tribunais como um órgão de governo distinto da Assembléia: (1) do ponto de vista da terminologia, quando o termo demos é usado como sinônimo de ekklesia, em geral se opõe ao termo dikasteria; (2) quanto à composição, se na assembléia podem entrar todos os cidadãos atenienses, nos tribunais entram apenas aqueles acima de 30 anos um dado não desprezível quando se considera que a baixa expectativa de vida (cerca de 25 anos); (3) os jurados dos tribunais deviam fazer o juramento dicástico, enquanto que os cidadãos em assembléia não faziam nada do tipo; (4) o sistema de voto também diferia, pois se na Assembléia o voto se realizava por meio dos braços levantados, nos tribunais a votação se dava utilizando os phedroi, ou seixos, que eram depositados e depois contados, o que dificultava uma contagem fraudulenta; (5) os debates nos tribunais, em geral com apenas dois discursos, eram vistos como sendo mais organizados, por oposição à multiplicidade das falas na Assembléia; (6) o custo de um dia de sessões nos tribunais era muito menor do que uma sessão na Assembléia - nos cálculos de Hansen, uma sessão da Assembléia com 6.600 cidadãos (recebendo 1 dracma cada), custaria o equivalente a cerca de 13 sessões de tribunal com 1000 jurados, (recebendo 3 óbolos cada)

Estas diferenças permitiriam então que se afirmasse que havia uma separação entre um poder legislativo e um poder judiciário na polis? Não, segundo Hansen, pois os tribunais acumulam diversas competências que seriam hoje descritas como propriamente políticas. Entre elas, as principais são: as dokimasiai (exame anterior à admissão de candidatos a cargos públicos), as euthunai (exame posterior ou prestação de contas de magistrados ao deixar o cargo), as eisangeliai (deposição de magistrados) e as graphai paranomon (ação contra propostas da Assembléia consideradas 
inconstitucionais). Estas ações públicas ocupariam um tempo considerável do sistema jurídico ateniense: Hansen aponta que no último mês do ano ocorriam as dokimasiai de cerca de 700 magistrados ingressantes além de alguns dos 500 conselheiros, do mesmo modo que no início do ano seguinte ocorriam as respectivas euthunai; quando às eisangelia, a partir do cálculo de nomes de generais depostos entre os mencionados nas fontes entre os anos de 432 e 355 a. C., Hansen afirma que, se o padrão se mantivesse caso todos os generais fossem mencionados nas fontes, cerca de dois a cada dez generais eram depostos pelos tribunais, numa proporção de assemelharia a democracia ateniense à França na época de Robespierre; e por fim, no caso das euthunai, Hansen calcula que a quantidade de ações ocorridas em duas décadas do século IV a. C. em Atenas seria o equivalente à mesma quantidade de ações ocorridas durante os séculos XIX e XX d. C. na Suprema Corte estadounidense (HANSEN, 1990, p. 233-9).

Da importância das ações públicas no direito ateniense Hansen passa para a percepção que os atenienses tinham do papel político dos tribunais populares: se no século V a. C. a Assembléia era vista como o principal espaço da soberania democrática, no século seguinte ela dividirá esta primazia com os tribunais populares. Hansen propõe que esta mudança foi causada pelo enfraquecimento dos poderes da Assembléia sobre as leis e sua imposição a partir das reformas legais que ocorreram com a restauração da democracia em 403 a. C.: em primeiro lugar, surgiu uma diferenciação entre nomos (lei, de validade permanente) e psephisma (decreto, de validade temporária ou aplicação individual), e a Assembléia, cujas decisões durante o século $\mathrm{V}$ a. C. podiam ser chamadas tanto de nomos quanto de psephisma, tornou-se responsável por decidir decretos e apenas propor leis, que a partir de então seriam analisadas por um grupo de cidadãos, os nomothetai, escolhidos por sorteio a partir da lista de 6 mil jurados; em segundo lugar, a Assembléia perdeu o poder de julgar casos políticos, competência agora exclusiva dos tribunais populares. A conjunção destes fatores, segundo Hansen, explica porque Aristóteles, na Política (1275a), dizia que o cidadão exerce seus direitos primordialmente sendo um jurado (dikastes) e um membro da assembléia (ekklesiastes), e na Constituição de Atenas (41.2) que "o povo fez de si mesmo senhor de tudo, e controla todas as coisas por meio dos decretos (psephismata) e dos tribunais (dikasteria)" - os tribunais seriam tão fundamentais para a democracia quanto a própria Assembléia. 
Esta é a argumentação de Hansen para enfatizar os poderes políticos dos tribunais. Mas vale a pena perguntar: o que é política, e o que são poderes políticos para o autor? Neste texto, como em quase toda sua obra, Hansen limita a política às instituições governamentais da polis ${ }^{32}$ : político é o caso que envolve membros do governo (conselheiros, magistrados), política é a execução de leis por meio das sentenças. O poder político dos tribunais, portanto, é a capacidade destes de interferir no governo da polis. Ora, aqui as críticas são semelhantes àquelas feitas acima à abordagem de $\mathrm{S}$. Todd sobre o direito ateniense (idem b): não há política fora das instituições governamentais? Discursos que contivessem discussões sobre a conduta ideal dos cidadãos, sobre a forma ideal de governo, sobre os melhores modos de se manter a democracia, só poderiam ser chamados de "políticos" quando estivessem presentes em uma ação pública? Hansen confunde "público" e "político", resumindo-os ao "estatal". Vale perguntar, então, se a política, como prática e como teoria, pode também surgir fora dos ambientes estatais. Um exemplo está no próprio texto do autor: o que é a Política de Aristóteles senão uma discussão política feita fora de qualquer espaço estatal (no nível discursivo e material), e mais ainda, por um meteco?

\footnotetext{
${ }^{32}$ Esta limitação é absolutamente consciente para o autor: um exemplo suficiente é a bem humorada nota que M. Hansen: o texto The Political Powers of People's Courts faz parte de uma coletânea que abre com um texto de Oswyn Murray sobre as abordagens historiográficas da polis, no qual o autor faz um paralelo com uma experiência descrita por Bertrand Russel acerca da mentalidade de macacos - cientistas alemães consideravam racional a atividade orientada por regras, enquanto estadounidenses viam na criatividade um elemento fundamental da racionalidade. M. Hansen então afirma em nota na primeira página de seu texto: "Meu macado (polis) é um Estado e a banana é a estrutura da polis, isto é, as instituições políticas"
} (HANSEN, 1990, p. 215, n. 1). 
4. Lugares da política: espaço, identidade e

\section{memória em Lísias}




\section{a) Usos políticos do espaço}

Atualmente, não faltam estudos, em diversas disciplinas (história, geografia, sociologia, antropologia, economia), que tratam dos usos políticos dos espaços no mundo contemporâneo: planejamentos e intervenções territoriais pelo Estado, políticas espaciais contra o Estado, apropriações e usos do espaço livres ou regulados, luta por espaços, luta entre espaços, funcionalizações e destruições de espaços. Diferente é o caso dos estudos históricos em Atenas: o termo "espaço político" aparece associado a "espaço público", e este a "espaço cívico", para daí seguir uma lista de "lugares políticos" como a assembléia da Pnix, o Conselho, os tribunais, o Areópago etc, ou seja, os lugares onde os cidadãos exercem seu poder.

Esta primeira parte do capítulo trata da questão dos usos políticos do espaço em Atenas tomando como referência quatros lugares: o porto, a casa, a rua e os tribunais, tal como são representados nos discursos de Lísias. Para cada lugar, será apresentada uma breve discussão historiográfica do tema seguido da análise de alguns trechos de discursos que podem trazer elementos importantes para a discussão sobre a política em cada um desses lugares. Antes, porém, cabe situar a discussão das relações entre espaço e política em geral e em Atenas em particular, para então nos voltarmos para a análise de cada um dos quatro lugares mencionados.

\section{Espaço e política}

O reconhecimento do caráter político possível do espaço é uma elaboração do século XX, particularmente na obra de Henri Lefebvre, filósofo de formação, que ao longo do século passado produziu dezenas de estudos que abrangiam da filosofia hegeliana à análise dos ritmos urbanos, da lingüística à sociologia rural, da teoria da revolução socialista ao urbanismo etc. Quanto ao tema específico das relações entre política e espaço, é importante destacar aqui sua produção teórica das décadas de 1960 e 1970, quando o autor, partindo da crítica da vida cotidiana no capitalismo avançado e da sociologia rural, iniciava um movimento na direção da crítica ao urbanismo e da 
formulação de uma teoria unitária do espaço ${ }^{33}$, culminando na publicação de Espaço e Política, de 1973, e do clássico A produção do Espaço, de 1974.

Tomemos um trecho do primeiro livro, de 1973, que elabora o caráter político do espaço a partir da crítica ao urbanismo. Discutindo as propostas epistemológicas dos urbanistas, ou seja, a criação de uma ciência do espaço do ponto de vista urbanístico, Lefebvre afirma que esta

ciência do espaço devia, pois, coroar e conter, ao mesmo tempo, o pensamento urbanístico. Mas aqui começavam as dificuldades. De fato, se a ciência é a ciência de um espaço formal, de uma forma espacial, ela implica uma logística implacável, e a ciência não poderia consistir senão numa soma de constrangimentos pesando sobre o conteúdo (as pessoas!). Em contrapartida, se nos voltarmos para o estudo do que vem povoar esta forma, seja as necessidades das pessoas, seja suas reivindicações, se centrarmos a reflexão sobre o conteúdo e não sobre a forma "pura", o que garante que esse conteúdo vai entrar nessa forma sem sofrer certas afrontas? O que garante que as pessoas e suas necessidades vão se deixar inserir na lógica sem resistência? Isso explica, ao que parece, que, apesar dos esforços, ainda não há epistemologia urbanística. [...]

Nessas perspectivas, referentes ao político e sua intervenção urbanística, conservava-se o postulado do espaço objetivo e neutro. Ora, é evidente, agora, que o espaço é político. O espaço não é um objeto científico descartado pela ideologia e pela política; ele sempre foi político e estratégico. Se esse espaço tem um aspecto neutro, indiferente em relação ao conteúdo, portanto "puramente" formal, abstrato de uma abstração racional, é precisamente porque ele já está ocupado, ordenado, já foi objeto de estratégias antigas, das quais nem sempre se encontram vestígios. $\mathrm{O}$ espaço foi formado, modelado a partir de elementos históricos ou naturais, mas politicamente. (LEFEBVRE, 2008, pp. 61-2).

Aqui, observa-se um duplo movimento: crítica interna, na medida em que uma "ciência urbanística" de um "espaço neutro", ou seja, sem política, implica, em si

${ }^{33}$ De acordo com o estudo de Remi Hess e Gabriele Weigand (2006), este é um dos períodos de maior produção bibliográfica do autor, que não se restringe à produção sobre a cidade e o espaço. A passagem acima citada, do cotidiano ao espaço, pode ser acompanhada nos livros: Crítica da vida cotidiana II (1961), Pirineus (1965), O direito à cidade (1968), Do rural ao urbano e A revolução urbana (1970), O pensamento marxista e a cidade (1972), Espaço e política (1973), A produção social do Espaço (1974). 
mesma, a imposição de uma forma predeterminada (o plano urbanístico) a um conteúdo (as pessoas e seus usos do espaço), e esta imposição só se dá com a intervenção do Estado; e crítica externa, na medida em que a História do espaço (que deixa ou não vestígios) revela os processos de formalização e abstração sobre espaços históricos, concretos. Esta consideração política do espaço permitiu que o autor se voltasse para a interpretação das alterações do espaço diante das transformações do capitalismo no século XX, como a produção capitalista do espaço (p.ex. as reformas urbanas), a colonização da espacialidade da vida cotidiana pelas relações capitalistas de produção (p.ex. a criação de espaços de lazer dirigidos ao consumo), e também o surgimento das lutas pelos espaços (p.ex. pelo direito à cidade) - estas interpretações influenciariam tanto a pesquisa acadêmica, especialmente os estudos de Geografia e Sociologia Urbana, quanto a disputa política do espaço, como no caso das lutas por moradia ou nos movimentos ecologistas ${ }^{34}$.

Da dupla crítica ao urbanismo, interna e externa, tomemos com mais atenção esta última: a história do espaço revela seu caráter político, desnaturaliza, tira qualquer eternidade da forma espacial. A história do espaço seria, portanto, crítica, contra qualquer aparência de estabilidade de um espaço que é sempre socialmente construído. Mas quais seriam os parâmetros desta história do espaço? Em A produção do espaço, de 1974, H. Lefebvre dá um exemplo particularmente oportuno:

Cada sociedade (portanto, cada modo de produção com as diversidades que engloba, as sociedades particulares nas quais se reconhece o conceito geral) produz um espaço, o seu. A Cité antiga não pode ser compreendida como uma coleção de pessoas e coisas no espaço; ela não pode ser mais concebida a partir de um certo número de textos e discursos sobre o espaço, ainda que alguns dentre eles, como o Crítias e o Timeu de Platão, ou o livro A da Metafísica aristotélica, forneçam conhecimentos insubstituíveis. A Cité teve sua prática espacial; ela moldou seu espaço próprio, isto é, apropriado. Daí a exigência nova de um estudo deste espaço que o apreenda como tal, na sua gênese e em sua forma, com seu tempo ou seus tempos

\footnotetext{
${ }^{34}$ Do mesmo modo que a produção bibliográfica de Henri Lefebvre é bastante numerosa, com dezenas de livros, também a produção bibliográfica sobre ele é extremamente vasta. Algumas indicações preciosas sobre a biografia, a trajetória intelectual e as influências de Henri Lefebvre se encontram em Smith (1986), Martins (1996), Carlos (1999), Hess (2000) e Damiani, Carlos e Seabra (2001).
} 
específicos (os ritmos da vida cotidiana), com seus centros e seu policentrismo (a ágora, o templo, o estádio etc). (LEFEBVRE, 1974, pp. 56).

"Cada sociedade produz seu espaço". Esta frase, como princípio metodológico, aponta para as possibilidades não apenas de uma leitura social dos espaços, como também para uma leitura espacial das sociedades: a análise do espaço produzido por uma sociedade, a sua espacialidade, coloca em questão a própria sociedade analisada. Mas seria possível um tal estudo quando se trata de uma "cidade antiga", a Atenas Clássica, por exemplo? Ora, um estudo do espaço "enquanto tal", neste caso esbarraria nas questões próprias à preservação de vestígios arqueológicos. Mas de qualquer modo, é possível, a partir de textos, acessar determinadas práticas espaciais de uma sociedade? Ficaríamos, com os textos, apenas no nível dos "discursos sobre o espaço"? Talvez os textos não sejam tão infecundos para uma discussão da produção do espaço. No mesmo livro da citação acima, Lefebvre discute, a certa altura, a questão das representações do espaço, e modo como estas representações se relacionam com as práticas espaciais. Certamente, os discursos sobre o espaço da polis não são apenas discursos, ou melhor, o sendo, fazem parte de um movimento de apropriação discursiva do espaço, por meio da imposição de valores e classificações sobre os espaços concretos, vividos.

Os discursos sobre o espaço seriam, portanto, parte de projetos de imposição de determinadas práticas a determinados lugares, ou seja, do estabelecimento de normas espaciais. Este caminho é desenvolvido, por exemplo por Marta M. de Andrade quando a autora analisa as cidades ideais de Platão e Aristóteles e a figuração das cerâmicas áticas como uma produção discursiva que procurava reservar o espaço público, urbano, à apropriação exclusiva dos cidadãos, cuja superioridade sobre mulheres, escravos e estrangeiros não seria contestada - este movimento discursivo, que a autora qualifica como "ideológico", transforma o espaço público em espaço cívico, ou seja, dominado pelos membros do corpo de cidadãos da polis (ANDRADE, 2002)

Entretanto, como a autora afirma, este projeto não é imune a contradições, assim como podem ter existido contra-projetos, ou ao menos discursos que trazem elementos contrários ao projeto de exclusividade cívica do espaço urbano. Estes são os termos, pois, de uma politização do espaço, que Marta M. de Andrade interpreta como a tentativa do corpo cívico de controlar e regular o espaço habitado (2002, pp. 225-35).

Mas seria possível pensar em uma politização do espaço no sentido contrário, ou seja, pelo uso e representação do espaço a partir da utilização de elementos que colocam 
em risco a exclusividade cívica? Uma análise que vai nesta direção é realizada por S. Mansouri, que encontra nos discursos dos oradores áticos e nas peças de Aristófanes uma apropriação política da ágora, por meio da discussão de temas da polis e da circulação das notícias a partir das oficinas de artesãos e do mercado (MANSOURI, 2002). Procuraremos, a seguir, discutir a questão da politização pelo avesso do espaço urbano da polis a partir da análise de alguns discursos do Corpus de Lísias que fazem menção a estes espaços, destacando os modos pelos quais outros usos e representações podem aparecer no contexto da retórica judiciária, heterotopias nas quais os habitantes, e não somente os cidadãos, adquirem uma dimensão política.

\section{O porto}

O Pireu é mencionado em doze discursos do Corpus de Lísias $(2,3,12,13,16$, $19,25,26,28,29,31,34)$, e seu significado tende a se concentrar em dois pólos: o Pireu como espaço físico, geralmente como local de operações militares da restauração democrática (discursos 2, 12, 13, 16, 19, 25, 26, 31, 34), e eventualmente como espaço de moradia (discursos 3, 29, 32); e o Pireu como marcação espacial da identidade democrática - "os do Pireu” em oposição à marcação oligarca "os da asty" (discursos 12, 13, 25, 28, 31). Este caráter duplo do Pireu nos discursos de Lisias, material e simbólico, faz parte da longa história das relações entre o principal porto da Ática e a democracia ateniense: entre os momentos desta história, estão os apelos de Temístocles que, de acordo com Tucídides (1.93.7), no contexto das Guerras Médicas, para que os atenienses deixassem a asty e se estabelecessem no Pireu, onde estariam realmente protegidos; assim como a afirmação de Aristóteles, no século IV, segundo o qual os habitantes do Pireu são mais democratas que os habitantes da asty (Política, 1303b).

Sitta Von Reden, em seu breve artigo The Peiraeus - a World apart, realiza um tratamento de algumas questões fundamentais para a história da relação entre o Pireu e a democracia. Para a autora, um centro urbano portuário apresenta problemas específicos ao conceito de polis: primeiro, a inversão da subordinação estrutural de um demos local para a asty; segundo, o porto é a mediação com o comércio internacional, questionando a ênfase ideológica na autarquia; e terceiro, a concentração e a importância de estrangeiros enfraquece o status de cidadão (von REDEN, 1995, p. 25). A partir destes aspectos, a autora procura analisar as relações políticas entre o Pireu e a asty, retomando tanto as instituições que faziam a mediação entre a asty e o porto quanto as 
representações sociais que ligavam o Pireu (e sua população de remadores, pilotos, cidadãos ou não) à democracia e ao poder marítimo; daí a crítica antidemocrática à importância do Pireu, como aquela presente em Platão, que propunha que a cidade ideal deveria ficar a cerca de 80 estádios de distância da costa - o dobro da distância entre a asty de Atenas e o Pireu. Outro exemplo da ligação entre o Pireu e a democracia é a história das Longas muralhas: se nos períodos democráticos havia um projeto de ligação física entre a asty e o Pireu, intensificada com a ocupação dos vãos da muralha durante a Guerra do Peloponeso, nos períodos oligárquicos esta ligação era rompida, seja pela criação de obstáculos em 411, seja pela demolição das muralhas em 404.

Após analisar as interações institucionais, econômicas, sociais e religiosas entre o Pireu e a asty, a autora afirma que a relação entre os dois centros urbanos áticos se dava por uma contradição entre política e economia: a asty dependia economicamente do Pireu, não somente pelo fornecimento de trigo como por diversas outras atividades artesanais e comerciais, ao mesmo tempo que o controlava politicamente (von REDEN, 1995, p. 35). Mas como se dá esta contradição controle político/dependência econômica na vida cotidiana dos habitantes do Pireu? Haveria um movimento contrário, de tentativa de controle político do Pireu sobre a asty, ou ao menos de negação deste controle? A autora cita, a certa altura (p. 30), o caso da demolição do obstáculo (a fortificação de Eetioneia) construída pela oligarquia de 411 para dificultar a passagem do Pireu para a asty, além da participação de metecos e escravos no exército que restaurou a democracia, a partir do Pireu, em 403 - estes dois eventos demonstram que o espaço do Pireu, para além da posição de objeto da ação governamental ou das representações sociais, democráticas ou oligárquicas, também poderia conter comportamentos políticos ativos, tanto de negação da ordem vigente como de (re)construção de outra.

O Pireu, enquanto espaço, apresenta um caráter político tanto objetivo quanto subjetivo. Como se dá esta política do espaço nos discursos de Lísias? Ora, como foi dito acima, nos discursos o termo Pireu aparece significando tanto o espaço físico das guerras democráticas quanto a marcação espacial da identidade democrática - em cada discurso tais significados aparecem de acordo com as necessidades retóricas, variando assim suas intensidades. Entretanto, em um discurso particular, estes dois significados são tão imbricados que vale a pena uma análise mais detida: trata-se do discurso Contra Agoratos (lys.13). 
Este discurso é uma acusação contra um certo Agoratos, segundo o orador filho de escravos, que teria causado a morte de Dionisodoros (cunhado do orador) e de outros cidadãos atenienses defensores da democracia ao denunciá-los aos Trinta, na época em que eles preparavam a derrubada da democracia. A datação do discurso é problemática, assim como seu enquadramento legal: defende-se normalmente que o caso tenha sido julgado não antes nem muito depois de 399, na mesma época em que diversos julgamentos públicos foram realizados (como o de Sócrates, por exemplo); e que o procedimento jurídico era uma apagoge, utilizada contra pessoas que desrespeitavam a suspensão de direitos cívicos (atimia) determinada por crimes anteriores, como por exemplo aparecer em público após ter cometido um assassinado (cf. TODD, 2000, pp. 137-140). O discurso Contra Agoratos aparece nos manuscritos logo em seguida do Contra Eratóstenes, e em certo sentido é paralelo a este, constituindo as duas principais fontes históricas, dentro do Corpus, para a história do regime dos Trinta e da Restauração democrática. Muitas questões podem ser tratadas a partir deste discurso; entretanto, serão tratados aqui apenas os modos como o porto do Pireu é engajado no discurso, e quais são os modos de apropriação política possíveis.

$\mathrm{O}$ orador relata os primeiros movimentos dos oligarcas para derrubar a democracia, logo após a derrota para os lacedemônios em 405: por meio de acusações e julgamentos fraudulentos, os oligarcas, com o apoio do Conselho, procuraram exterminar todos aqueles que se opunham ao acordo de paz com Esparta tal como Teramenes havia negociado, que previa a destruição das muralhas e a entrega da marinha ateniense aos lacedemônios. O método de se chegar aos líderes democratas utilizado pelos oligarcas foi a delação: por meio de um certo Teocritus, os oligarcas chegaram até Agoratos, que ao que parece tinha prestígio entre os democratas. $\mathrm{O}$ Conselho baixou um decreto com uma ordem de prender Agoratos, o que, segundo o orador, já era do conhecimento deste: Agoratos seria uma isca para a prisão dos verdadeiros democratas. Diz o orador:

Quando este decreto foi aprovado, membros selecionados do Conselho desceram para ver Agoratos no Pireu; por acaso encontraram-no na ágora, e quiseram prendê-lo. Estavam presentes Nicias, Nicomenes e vários outros, que, vendo que as coisas não estavam as melhores na polis, disseram que não permitiriam que Agoratos fosse preso. Ao contrário, eles defenderam sua liberdade, deram garantias e concordaram em levá-lo para diante do Conselho. 
Os membros do Conselho registraram os nomes daqueles que estavam provendo segurança e evitando a prisão, e voltaram para a asty. Agoratos e seus protetores sentaram-se no altar em Muníquia, e tão logo o fizeram, começaram a discutir o que fazer. Os protetores e os outros decidiram que eles deveriam promover a fuga de Agoratos tão breve quanto possível. Eles compraram dois barcos que estariam ancorados em local próximo, e imploraram que ele fugisse de Atenas por quaisquer meios possíveis. Disseram que eles navegariam com ele, até a situação se tornar estável, argumentando que se ele fosse levado para diante do Conselho, ele seria talvez compelido sob tortura a revelar os nomes dos atenienses [...]. (13.23-5).

O discurso segue com a narrativa da prisão de Agoratos após este ter deixado o altar (voluntariamente segundo a acusação), e a subseqüente deposição de nomes de cidadãos democratas ao Conselho, entre estes o de Dionisodoros, cunhado do orador. Após esta narrativa, o orador faz uma longa reflexão sobre o papel destas denúncias para a instalação da oligarquia: não houvessem os democratas sido presos e executados, os Trinta não dominariam a cidade, as muralhas não teriam sido derrubadas nem a marinha entregue aos lacedemônios (outra paz teria sido arranjada), e nenhum dos males que se abateram sobre a cidade teriam ocorrido.

Amplificação à parte, voltemos ao trecho citado. O que é o Pireu neste trecho? Primeiro, é o local onde estão Agoratos e alguns dos cidadãos democratas; segundo, é o local onde um decreto que visava o fim da democracia (a prisão de Agoratos) é negado; terceiro, é o local onde está o altar de Muníquia, utilizado para a proteção dos democratas; quarto, é o local de fuga dos democratas diante da ofensiva oligarca. Em todos estes sentidos, o Pireu é caracterizado como espaço democrático, por oposição à asty, dominada pelos oligarcas. Esta caracterização, feita cerca de 5 anos após os acontecimentos narrados, se articula com uma memória política que encontra no porto, no altar de Muníquia, em suas ruas, o suporte material de significação democrática. Pireu como espaço democrático: a narrativa, situando no Pireu a resistência à oligarquia ainda na época de sua instalação, contribui para a formação da memória espacial da democracia, sediada nos lugares do porto.

Mas como adiantado acima, não é apenas como espaço físico que o Pireu aparece no discurso - voltemos ao discurso. Como de costume, os acusados utilizavam a participação na restauração democrática de 403 como um argumento de prestígio, e quanto mais cedo o ingresso no exército democrata, maior a honra. Sabe-se que a 
restauração começou com a tomada pelo exército democrata da fortificação de File, ao norte da Ática, onde ocorreu a primeira batalha com os oligarcas que ficaram na cidade; em um segundo momento, o exército marchou para o Pireu e, tomando o porto, forçaram as negociações de paz com os oligarcas e o restabelecimento do regime democrático (com a mediação do rei espartano Pausânias). Agoratos, diz o orador, alegará em sua defesa ter participado da restauração desde a tomada de File - este fato não será negado. Contudo, o orador afirma que, longe de ter sido acolhido entre os restauradores, Agoratos encontrou em File alguns dos cidadãos exilados por conta de suas denúncias, que só não o mataram porque um dos líderes, Anitus, os impediu dizendo que as punições só ocorreriam após o retorno; de qualquer modo, nenhum dos restauradores dirigiu a palavra a Agoratos, considerado impuro (13.77-80). O orador segue a narrativa:

Quando foram feitos os acordos entre os dois lados, e os do Pireu subiram em procissão à Acrópole, Aesimus à frente dos cidadãos, o acusado comportou-se com ultraje: ele pegou armas e tentou acompanhar a procissão para a asty junto dos hoplitas. Quando todos estavam à frente dos portões e depunham as armas, Aesimus percebeu sua presença, aproximou-se dele, tomou seu escudo e lançou-o longe, e disse a ele para ir para o inferno. Disse que Agoratos, sendo um assassino, não poderia tomar parte na procissão à Atena. (13.80).

A função retórica deste trecho é óbvia: tirar qualquer valor argumentativo da alegação de ter participado da restauração. Mas além disso, o orador utiliza, para caracterizar os restauradores, de uma marcação espacial: "os do Pireu”, hoi ek Peiraios, no genitivo. Em outros discursos, em particular o Contra Eratóstenes (lys.12), é comum a oposição entre "os do Pireu” e "os da asty”, implícita no Contra Agoratos. Mas o que significa esta marcação espacial?

Em uma primeira aproximação, é uma marcação óbvia que parte do lugar onde os restauradores finalmente derrotaram os oligarcas. Mas uma leitura mais profunda é possível. Seguindo um caminho mais antropológico, a historiadora Nicole Loraux argumenta a diferenciação entre "os de File" e "os do Pireu" se articulava à questão da presença de não cidadãos entre os restauradores: a memória cívica ateniense privilegiava o momento de File, quando os atenienses exilados iniciaram a restauração, apagado assim o momento do Pireu, quando "se reuniram as tropas, que se dizia 'misturadas', de democratas" (LORAUX, 2005, p. 256) - ou seja, a memória cívica 
apagava a participação de não-cidadãos, metecos e escravos, na restauração da democracia. Podemos ir além da interpretação de N. Loraux, por meio da oposição entre agricultura (File) e artesanato/comércio (Pireu), mas de todo modo constrói-se uma cultura política que tende a associar o Pireu à democracia radical que encontrará em Aristóteles umas das suas principais expressões. Segundo a autora, privilegiar File era enfraquecer a democracia, criando um regime que, em certo sentido, estava mais próximo da oligarquia moderada de Teramenes do que da democracia na época de Péricles.

De qualquer maneira, existe uma tensão no espaço discursivo ateniense quanto a se utilizar o Pireu ou File como a marcação espacial adequada para a restauração. Assim, Ésquines diz "homens de File" se referindo aos restaurados, Demóstenes utiliza o "demos do Pireu”, e Aristóteles utilizará ambos, na Constituição de Atenas (cf. LORAUX, 2005, p. 330, n. 38). Os discursos do Corpus de Lísias também se utilizam de ambos, mas nos parece que o Pireu é prioritário: assim, mesmo em um discurso feito em defesa de um cidadão que permaneceu na asty durante a oligarquia dos Trinta, datado da mesma época do Contra Agoratos, o orador, contrapondo-se aos discursos difamatórios da acusação, afirma:

Eu tornarei claro que seus discursos [dos acusadores] são falsos a respeito de tudo, e que eu me conduzi como teria feito o melhor dos do Pireu

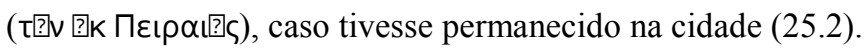

Fica claro, portanto, a identificação entre o Pireu e a ética democrática, que se torna a medida para a avaliação da conduta daqueles que permaneceram.

Retomando o texto de Sitta von Reden e a associação Pireu-democracia, é possível afirmar, por um lado, que os discursos de Lísias são peças fundamentais desta construção discursiva; por outro lado, que o Pireu, justamente um local intensamente povoado por metecos, é um espaço políticamente carregado de significação, tanto materialmente quanto simbolicamente. E para além do texto citado, pode-se sugerir que esta associação Pireu-democracia está ligada, também, à associação metecosdemocracia também presente nos discursos de Lísias ${ }^{35}$.

\footnotetext{
${ }^{35}$ Ver, neste capítulo (item b), a discussão sobre as identidades de cidadãos e metecos
} 
Tradicionalmente, os estudos feitos por classicistas, historiadores e arqueólogos associaram o espaço físico da habitação grega ao termo oikos, normalmente associado à família, à propriedade privada, à hierarquia do chefe da família e dono da casa, à vida cotidiana, por fim à privacidade, tudo isso por oposição ao termo polis, associado à comunidade dos cidadãos iguais perante a lei, à política, aos bens coletivos, em uma palavra, à publicidade das relações sociais. Assim, a oposição oikos/polis, “casa"/"cidade", é a materialização da oposição idios/koinos, "esfera pública"/“"esfera privada”. De acordo com a historiadora Marta M. de Andrade,

[...] a maioria desses estudos não consegue ultrapassar a fronteira entre uma ideologia ligada a um simbolismo que fazia da relação do cidadão com o território habitado uma relação privilegiada, se não exclusiva, extrapolando as fronteiras do discurso e estabelecendo mecanicamente um paralelo com a vida social e mesmo o cotidiano. (ANDRADE, 2002, p. 94).

Assim, os estudos sobre a casa grega acabaram reproduzindo uma ideologia cara aos cidadãos, transformando discurso em fato empírico. Uma das conseqüências desta relação acrítica dos estudiosos com suas fontes seria a discussão sobre as funções dos espaços: o teatro, a ágora, a rua, a assembléia da Pnix, o conselho, seriam espaços públicos, os quais apenas homens cidadãos poderiam freqüentar e exercer suas atividade políticas; a casa seria o espaço privado, ocupado pela família, com a função exclusiva da habitação.

[...] essa adscrição acaba por encerrar o problema da organização do espaço nas amarras de uma ideologia que só tem fundamento e eficácia quando se considera o cidadão e não o habitante e suas práticas cotidianas, assim como sua vivência do espaço habitado. O preço dessa adscrição normalmente vem na forma da função: assim, funções coletivas, públicas, políticas e religiosas seriam definidoras do espaço da polis, enquanto funções domésticas, como tudo o que se refere a casamento e criação dos filhos, relações familiares e de amizade, definiriam o espaço privado. [...] Mas e quanto ao uso que se faz do espaço? E quanto aos diversos modos de se apropriar de um espaço vivido cotidianamente? Até que ponto a definição de duas categorias funcionais seria explicativa dessa apropriação cotidiana? (ANDRADE, 2002, p. 95; grifo meu). 
A partir destas questões a autora realiza um duplo movimento analítico: (1) os discursos sobre o espaço deixam de ser vistos como retrato fiel da experiência do espaço para se tornarem estratégias discursivas, em uma palavra, ideologia; e (2) passa-se da descrição funcional dos espaços para a problematização de seus usos, acessíveis pelo menos indiretamente nas fontes escritas, como também pelos vestígios arqueológicos. Este duplo movimento faz com que a autora realize uma rediscussão das relações entre gênero e espaço doméstico, relações que, mais do que a oposição público/privado, tinham como parâmetro a oposição dentro/fora da casa.

Esta oposição é encontrada em diversos textos: procurava-se discursivamente relegar a mulher ao interior, e o homem ao exterior; no entanto, outras leituras das fontes, textuais e materiais, permitem que se encontrem brechas e contradições nesta dissociação (ANDRADE, 2002, p. 112). Mas qual é o lugar da política? Se restringirmos a política àquilo que se fazia institucionalmente (legislar, julgar, ocupar magistraturas e exercer o sacerdócio - as timai do cidadão segundo Aristóteles, Política, 1278a), decerto que os lugares da política seriam a Assembléia, o Conselho, os tribunais, mas certamente não a casa, ou mesmo o interior da casa. Mas se pensarmos em uma noção mais ampla de política, como atividade que visa a polis, suas leis, sua reprodução, talvez seja possível analisar o espaço da casa em suas implicações políticas.

A história de uma traição em Atenas é ilustrativa a este respeito. O discurso Sobre o assassinato de Eratóstenes (lys.1), que não tem qualquer indicação de datação, é uma defesa que visa justificar o assassinato cometido por um certo Eufileto, um camponês atenienses, contra Eratóstenes ${ }^{36}$, que teria seduzido sua mulher.

A história teria se passado, segundo o orador, da seguinte maneira: durante algum tempo, Eufileto se sentiu um marido de sorte. A vigilância necessária dos primeiros tempos de casado se tornou, após o nascimento da criança, uma íntima confiança: casado com uma mulher sábia e frugal, pai de uma criança sadia, senhor de

\footnotetext{
${ }^{36}$ Não se sabe se este Eratóstenes é o mesmo Eratóstenes acusado por Lísias em lys.12, ou seja, o membro dos Trinta que seria o responsável (segundo a acusação) pelo assassinato do irmão de Lísias, Polemarco. Existem indícios contrários e favoráveis à identificação: contra, em lys.1 não é feita nenhuma referência à participação no regime dos Trinta ou mesmo a qualquer comportamento oligárquico do acusado, argumento muito comum em processos privados; pro, não se sabe como um camponês como Eufileto, que possuía apenas uma escrava, conseguiria pagar um serviço (provavelmente) caro de um logógrafo para escrever seu discurso de defesa, a menos que o logógrafo (provavelmente Lísias) tivesse alguma desavença anterior contra o acusado (TODD, 2000, p. 15).
} 
uma casa estável - a vida parecia agradável a Eufileto. Mas eis que uma desgraça traria outras: a mãe de Eufileto morre; e durante o funeral, sua esposa é vista por Eratóstenes, homem que, no futuro, causaria a ruína de Eufileto sendo amante de sua esposa. Com a ajuda de uma escrava, Eratóstenes, o amante, corrompeu a esposa de Eufileto, e cometia o crime na própria casa do marido traído. A esposa de Eufileto não tinha pouca imaginação: se antes marido e mulher dormiam em quartos de andares diferentes (o marido embaixo, a mulher em cima), a esposa, alegando riscos que a criança corria no descer escadas, inverteu a ordem, e enquanto Eufileto dormia tranquilamente no quarto de cima, o amante entrava no quarto térreo da esposa. Certa vez, Eufileto desconfiou do abrir e fechar de portas à noite: a esposa disse que era devido à falta de óleo para lamparina do bebê, e que havia ido ao vizinho pedir óleo emprestado. Eufileto acreditou, pois, segundo ele mesmo diria, não era dos maridos mais espertos. Mas, depois de um certo tempo, a inconsciência de Eufileto teria fim: uma mulher de idade avançada, que havia sido desprezada por Eratóstenes, revela a trama ao marido traído. Perturbado, Eufileto carrega sua escrava, cúmplice da traição, para a casa de um amigo, e a interroga: a escrava primeiro nega tudo absolutamente, mas após Eufileto pronunciar o nome "Eratóstenes", ela desmaia; depois, ajoelhada, implora o perdão. Eufileto o concede, mas sob uma condição: ele queria o flagrante do adultério, e a escrava deveria promovê-lo.

Quatro dias depois, enquanto Eufileto dormia após almoçar, Eratóstenes entrou em sua casa; a escrava de Eufileto o acordou e contou o que ocorria. Eufileto então reuniu amigos e, todos armados, entraram em sua casa. Diz o orador:

Nós arrombamos a porta do quarto, e aqueles de nós que foram os primeiros a entrar o viram [Eratóstenes] deitado próximo de minha esposa. Os outros, que entraram depois, ainda o viram levantando nu da cama. Eu o golpeei, senhores, derrubando-o; torci seus dois braços por trás das costas e os prendi, e perguntei a ele por que ele havia cometido tamanho ultraje ( $\delta$ ı? tí

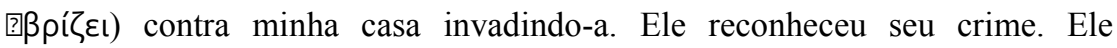
implorou, suplicou para que eu não o matasse, mas aceitasse uma compensação. Eu respondi: 'Não sou eu quem te matará, mas as leis da cidade. Você desrespeitou a lei e teve menos cuidado com ela do que com seu próprio prazer. Você preferiu cometer este crime contra minha esposa e meus filhos a conduzir-se responsavelmente e obedecendo às leis'. Foi assim, senhores, que ele encontrou o destino que a lei prescreve para aqueles que se conduzem desta maneira". (1.24-7). 
O caso é que, após o assassinato, a família de Eratóstenes acusou Eufileto de ter armado o adultério, pois já possuía desavenças com Eratóstenes: assim, ao invés de estar cumprindo a lei draconiana que previa a morte do adúltero se pego em flagrante, Eufileto estava realizando um assassinato premeditado. É contra esta acusação que se dirige o discurso de defesa Contra o assassinato de Eratóstenes.

Voltemos ao trecho citado. Vemos aqui agindo, muito mais do que uma oposição entre público e privado, uma oposição entre dentro e fora da casa, que serve como parâmetro para se definir o ultraje, a hubris: de um lado, a entrada do estranho sob a direção da mulher e anuência da escrava, caracterizada como invasão, configurando o crime; de outro, a entrada dos amigos de Eufileto, a convite deste, cumprindo a função de testemunhas da realização da justiça. O que está em questão aqui é poder sobre a circulação de pessoas de fora para dentro da casa, não o isolamento da mulher: o marido procura reinstaurar seu poder ${ }^{37}$, contra as práticas dirigidas pela mulher - a escrava funciona como a mediação deste trânsito, pois é somente com a ajuda dela que Eufileto tem o conhecimento e as condições para agir.

Muito já foi escrito para se realizar a interpretação do papel do marido, da esposa e da escrava doméstica na organização do espaço privado em Atenas a partir deste discurso. Destacaremos aqui, entretanto, uma questão que tem passado, ao que parece, desapercebida destas interpretações: quando Eufileto diz para Eratóstenes que não era ele que o matava, mas as leis da polis, no que tinha se transformado a casa? Ainda era espaço doméstico, do abrigo, da moradia, da privacidade? Ora, temporariamente, a casa havia se tornado tribunal e local de execução: os amigos do marido traído, como testemunhas, ao lado do questionamento do acusado e da enunciação da lei, reforçavam esta simulação. Na fala de Eufileto, a casa deixava de ser apenas casa, para se transformar na cidade; o adultério deixava de ser apenas adultério, para se transformar num crime contra as leis como um todo; e o assassinato ampliava-se

\footnotetext{
${ }^{37}$ A questão do convite/invasão, extrapolando da casa para a polis como um todo, poderia trazer hipóteses interessantes para a questão dos metecos atenienses: Lísias, quando fala da migração de seu pai de Siracusa para Atenas, enfatiza que o fez a pedido de Péricles - estaria Lísias aqui jogando com a oposição dentro/fora, diferenciando os metecos convidados dos não-convidados? Havia uma cultura compartilhada em Atenas que partir da oposição, tanto no nível da casa quanto no da cidade, entre dentro/fora, e isso regulava as relações entre ateniense e não-atenienses? Esta hipótese será desenvolvida em outro momento da dissertação (capítulo 8).
} 
no sentido da realização da justiça da polis em nome de uma ética dos cidadãos. Em uma palavra, fazia política dentro da casa de Eufileto.

Pode-se argumentar, certamente, que era um momento excepcional, e que não era sempre que um marido surpreendia um adúltero com testemunhas e enunciava as leis antes de matá-lo. Não obstante, não se procura aqui argumentar a normalidade ou a excepcionalidade do evento; pelo contrário, procura-se demonstrar que, em determinadas situações, a casa poderia conter ações que visavam diretamente a polis e suas leis, e assim tais ações assumiam um estatuto propriamente político.

Se faz sentido esta possibilidade da política no espaço da casa, abrem-se caminhos para se problematizar outras situações propriamente políticas que acontecem dentro de uma casa, em particular as discussões políticas e filosóficas durante banquetes e outras reuniões domésticas, como atesta o livro 1 da República de Platão - discussão sobre a justiça que ocorre, ficticiamente, na casa da família de Lísias, entre metecos ou mesmo os distúrbios políticos associados à banquetes de associações elitistas (as hetaireai) que assumiam um caráter oligárquico (LIMA, 2000, p. 37).

A rua

Se a casa foi considerada tradicionalmente como o espaço privado por excelência em Atenas, o mesmo não se pode dizer quanto à rua como espaço público. Dada a confusão, nas fontes e na historiografia, entre espaço público e espaço político institucional, a rua teria de concorrer a este status com espaços consagrados, como a assembléia na Pnix, o Conselho, o Areópago, os tribunais etc. Seja por esta confusão, seja pela escassez de evidências (textuais ou materiais), poucos são os estudos dedicados à uma análise do conjunto das ruas do ponto de vista tanto empírico quanto simbólico. Um exemplo é o livro do arquiteto e urbanista Jonas Malaco sobre as significações possíveis da disposição de ruas e blocos de casas na asty ateniense, intitulado Da forma urbana: o casario de Atenas (2002): neste estudo, o autor discute questões como a privacidade e a publicidade dos espaços, solidariedade e individualidade, entre outras, a partir do traçado das ruas nas plantas relativas ao período clássico; entretanto, ainda que repleto de idéias, a abordagem do autor permanece excessivamente especulativa (um dos métodos é imaginar-se andando pelas ruas) e fundada em problemáticas sociais e políticas de períodos históricos 
determinados (a filosofia política do século XVII), diferentes tanto do objeto, a sociedade ateniense do período clássico, quanto do sujeito, a sociedade brasileira de fins do século XX - as reflexões sobre o traçado acabam reificando categorias históricas específicas, como indivíduo, coletividade, ação coletiva etc, sem a mediação do diálogo entre o analista e as fontes.

Mas qual é o estatuto da rua na polis? Quais são as atividades adequadas à rua, quais as planejadas, quais as transgredidas? E mais: haveria espaço para a prática política na rua? Um argumento em um discurso do Corpus pode trazer elementos importantes para a questão. No famoso Contra Eratóstenes (lys.12), o orador (o próprio Lísias), em um determinado momento, realiza um breve interrogatório do acusado de ser o responsável pela execução injusta de seu irmão, o também meteco Polemarco:

\footnotetext{
- Você prendeu Polemarco sumariamente ou não?

- Eu obedeci ordens daqueles no poder, porque eu tinha medo.

- Você estava presente no Conselho durante a discussão sobre nós [os metecos escolhidos, pela riqueza, a serem presos e executados]?

- Estava.

- Você falou a favor ou contra aqueles que pediam nossa execução?

-Falei contra eles, para tentar evitar que vocês fossem mortos.

- O fez na crença de que nós estávamos sofrendo injustiça?

- Sim. (12.25).
}

Após este breve interrogatório, Lísias argumenta contra as respostas de Eratóstenes, primeiro afirmando que o fato de ter falado contra as execuções e mesmo assim tê-las promovido não tira sua culpa, em seguida que os Trinta não testariam sua lealdade no caso de metecos, portanto não é plausível que o acusado tenha sido contra a proposta, depois que os Trinta não podem ser perdoados jogando a culpa nos Trinta, e por fim que Eratóstenes, se quisesse, poderia ter descumprido a ordem de prender Polemarco. Destes argumentos, é o último que mais interessa aqui: diz o orador que

Eratóstenes agarrou-o e prendeu-o não em casa mas não rua, onde ele poderia ter deixado tanto Polemarco quanto as instruções dos Trinta invioladas. Vocês estão irritados contra todos aqueles que invadiram suas casas a sua procura, de vocês e de qualquer um de suas famílias. Mas se vocês devem perdoar aqueles que mataram outros para salvar a si mesmos, então seria mais legítimo perdoar aqueles que conduziram prisões nas casas, pois era perigoso 
para eles não irem onde foram enviados e, quando encontrassem alguém, negálo. Eratóstenes, por outro lado, poderia ter alegado que ele não havia encontrado Polemarco ou ele nunca o viu: não existiam quaisquer meios de verificar isso, e então não poderia ser contestado se seus inimigos o quisessem

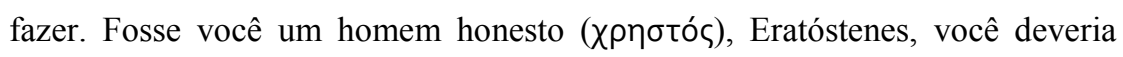
muito antes ter alertado aqueles que iriam morrer injustamente, a prender aqueles que seriam injustamente executados. Mas não, suas ações são claramente ações de alguém que está aproveitando o que estava acontecendo, e não tentando remediá-la. (12.30-32).

Ora, aqui o argumento opõe a prisão na casa e a prisão na rua: na primeira seria arriscado não ir e, indo, não efetuar a prisão; na segunda, havia a possibilidade de fingir não ter visto o alvo, pois não poderia haver provas disso ${ }^{38}$. Não cabe aqui discutir se, de fato, havia esta oposição, ou quais seus obstáculos. Independente dos limites para a realização de tal estratégia pelo acusado, o orador escolheu a rua como lugar plausível para a localização da negação das instruções dos Trinta, que eram não apenas oligarcas, mas também injustas, como havia admitido o acusado. A rua, neste trecho, se torna o espaço (possível e plausível na retórica) da negação de uma instrução injusta de um governo oligarca, e portanto, a rua poderia conter uma atividade propriamente democrática, entendida aqui como contra-poder: de um lado, a determinação oligárquica, injusta, e de outro, a (possível) negação democrática, justa. Rua como espaço de realização da justiça democrática ou como espaço da reprodução da injustiça oligárquica: o que fica é que a rua se torna um espaço político, de poder e contra-poder, e assim que é inserida na retórica de um discurso que se coloca, abertamente, pelo acerto de contas com o regime oligárquico, personificado, então, em Eratóstenes.

\section{O tribunal}

Já foi bastante enfatizado o papel político dos tribunais populares, suas relações institucionais com outros corpos governamentais atenienses, como a Assembléia, o Conselho, as magistraturas etc. Mas como se usava o espaço do tribunal? Quais eram os

38 S. TODD (2000, p. 122, n.14) considera fraco este argumento, pois ignora a possibilidade de que Eratóstenes estivesse acompanhado de ajudantes, conforme mencionado alguns parágrafos antes, os quais poderiam denunciar a negligência. 
modos de uso do espaço do tribunal enquanto materialidade e encontro social? Quais eram os impactos deste uso sobre as estratégias retóricas, e vice-e-versa? A historiografia já realizou estudos sobre os componentes dos tribunais, seu pessoal, os tipos de procedimentos, entre outros fatores estruturais (MOSSÉ, 1985, PP. 72-81; TODD, 1993, pp. 77-166; HANSEN, 1993, pp. 213-62); entretanto, uma série de usos e apropriações cotidianas do espaço, e suas significações sociais, foram negligenciadas nestes estudos.

As análises a seguir procuram demonstrar como, a partir de determinadas técnicas retóricas, os discursos ressignificam o espaço do tribunal investindo-o com funções que ultrapassam a situação específica do julgamento. É preciso analisar, portanto, a relação entre a institucionalidade do espaço do tribunal e as técnicas retóricas empregadas nos discursos: em que medida a composição do júri, o procedimento judicial, a presença de magistrados, levam o orador a fazer determinadas escolhas retóricas? Um exemplo interessante está no discurso Sobre a propriedade de Eraton (lys.17), datado provavelmente da metade da década de 390 a. C., o orador reclama sua parte na propriedade confiscada pelo Tesouro ateniense pertencente a um certo Eraton, então morto, mas que enquanto vivo havia contraído uma dívida de dois talentos com o pai do orador. Quando Eraton morreu, seus filhos pararam de pagar a dívida, o que gerou uma ação do pai do orador contra um dos filhos, exigindo propriedades da família como pagamento da dívida. O pai do orador venceu a ação, ainda que algumas propriedades permanecessem em litígio; entretanto, posteriormente (o discurso não indica quando), foi movida uma ação de confisco integral das propriedades da família de Eraton pelo Tesouro, inclusive aquelas que haviam sido adquiridas, judicialmente, pelo pai do orador. Este, então, move uma ação contra o Tesouro para reclamar sua parte no confisco, um procedimento chamado diadikasma. Ora, é fundamental para o orador, quando está em litígio contra a própria polis, não enfatizar este oposição, posto que está discursando para jurados que representam, antes de tudo, a parte adversária: portanto, o orador enfatiza que, se rigorosamente deveria receber toda a propriedade confiscada pelo Tesouro, ele está reclamando apenas a terça parte, ou seja, aquilo que seu pai havia ganho de um dos filhos de Eraton. Assim, ele afirma que

Foi demonstrado, senhores do júri, que eu não estou argumentando injustamente que esta diadikasma deveria ser decidida em meu favor, mas eu 
estou afirmando que a propriedade deveria retornar a mim somente após entregar para a polis muito do que é meu. É razoável, a meu ver, realizar esta requisição diante de vocês e diante dos magistrados das rendas na sua presença. (17.10)

O procedimento empregado para o caso gera técnicas retóricas específicas, pelas quais o orador transforma o confisco de uma propriedade em um ato voluntário de doação para a polis; não é a justiça que está em questão, mas a vantagem ou a desvantagem para a polis. Esta situação, na qual o orador não pode ser visto como adversário da polis (ainda que o seja de fato), é criada pela própria natureza do corpo de jurados no tribunal: a identificação jurados-polis obriga o orador a enfatizar que está abrindo mão de sua justiça particular em nome do bem da polis. É por meio do engajamento de valores sociais - em particular, a complementaridade entre idios (o interesse privado do litigante) e koinos (o interesse público da polis) - na situação específica de um discurso pronunciado no espaço institucional do tribunal, regido por normas que vão desde as leis solonianas até as regras de tempo de fala, e no qual está presente um auditório constituído por jurados que devem julgar de acordo, ao mesmo tempo, com as maiores vantagem para a polis e com a justiça.

Esta oposição entre vantagem da polis (confisco total pelo Tesouro) e justiça (devolução da propriedade ao orador) é amenizada, pelo discurso, por meio da idéia de doação: o orador cede à polis o que lhe é de direito. Não precisaria fazer isso, certamente, em um configuração institucional na qual os jurados não fossem identificados à polis: como é esse o caso, deve torcer seu discurso de modo a não ser completamente prejudicado. Vemos aqui, portanto, como a institucionalidade do espaço do tribunal é reposta pelo discurso, pela própria menção à presença do júri (como defensores da polis) e de alguns magistrados (syndikoi), e quais seus impactos para a organização do discurso. Esta reposição é política, na medida em que visa a organização institucional da justiça: a contradição entre vantagem da polis e justiça, criada pela própria institucionalidade do tribunal, se denunciada, é ao mesmo tempo amenizada pelo discurso - mas de todo modo, o que está em questão é a relação entre o cidadão e a polis, diante do que o orador é levado a ceder pelo fato de que, institucionalmente, os jurados são a polis.

Dito isto, tendo em mente a institucionalidade do espaço do tribunal (suas funções, seus usos, seus conteúdos, as interações prescritas e/ou permitidas etc), 
passemos para a análise de alguns modos de ressignificação do espaço dos tribunais em espaços de: (1) produção de ética por meio da exemplaridade das decisões judiciais; (2) formulação e crítica de teorias políticas, por meio da discussão dos pressupostos da argumentação; e (3) de produção e crítica da memória política ateniense.

Tribunal como espaço de produção de ética. No discurso Contra Epícrates: epílogo (lys. 27), o orador acusa um magistrado ateniense, Epícrates, e seus companheiros (não especificados) de praticar corrupção e se enriquecer ilicitamente: durante a guerra (provavelmente a Guerra Coríntia de 395 a 387), o acusado passou da pobreza à riqueza, roubando os fundos públicos enquanto a polis passava por dificuldades econômicas (27.9-10). Não se sabe ao certo se o discurso faz parte da deposição deste magistrado (eisangelia) ou de sua prestação de contas após a magistratura (euthunai), assim como não se sabe se ele foi pronunciado na Assembléia ou no tribunal, pois o auditório é ora mencionado como "homens de Atenas" (como na Assembléia), ora como "senhores do júri” (como no tribunal) - mais provavelmente neste último, não somente porque "senhores do júri" não caberia em uma Assembléia, quanto porque no decorrer do quarto século acumulou funções da assembléia, como a eisangelia. De qualquer modo, este discurso introduz um elemento de grande interesse para a análise da apropriação cotidiana do espaço: a presença dos magistrados durante o julgamento, e as conseqüências desta presença para o discurso e para o júri. Segundo o orador, a decisão de punir um magistrado sabidamente corrupto seria um exemplo não apenas para o acusado, mas para todo o corpo de magistrados, os quais, aliás,

\footnotetext{
vieram aqui, não para nos ouvir, mas para saber qual atitude vocês terão para com os criminosos. Se vocês votarem pela absolvição destes homens, então não parecerá a eles terrível que eles tenham enganado vocês e estejam lucrando com a sua propriedade. Se, entretanto, vocês os condenarem e os punirem com a morte, pelo mesmo voto vocês punirão os acusados e farão os outros terem uma melhor conduta no futuro do que eles têm agora. (27.7).
}

Esta presença dos outros magistrados, provavelmente especulada pelo logógrafo, faz com que seja enfatizado o caráter exemplar da condenação em sua imediatez: os criminosos em potencial estão no mesmo espaço do júri. Assim, não se trata somente de um julgamento contra Epícrates, mas a definição da relação da polis com seus magistrados no sentido de uma (des)normatização de sua conduta. O exemplo aos 
magistrados transforma o tribunal em espaço definidor das relações entre as instituições, articulando tanto aos valores cívicos (o respeito às leis), quando às circunstâncias econômicas (a escassez dos fundos públicos). Não se julga somente Epícrates: se reproduz a própria polis, e é esta dimensão propriamente política que colabora para a condenação do acusado. $\mathrm{O}$ discurso retórico ressignifica o espaço do tribunal, por meio desta amplificação do impacto das decisões tomadas, como um lugar de produção e imposição ética aos magistrados, produção e imposição tornadas urgentes diante da presença física de seu objeto, os magistrados.

Outras ressignificações do espaço do tribunal são perceptíveis:

Tribunal como espaço de formulação e crítica de teorias políticas. Dois discursos são extremamente claros neste ponto: em primeiro lugar, a discussão da naturalidade ou artificialidade da opção política dos indivíduos realizada em Defesa a uma acusação de subverter a democracia (lys.25.7-11); em segundo lugar, a discussão da relação entre riqueza e civismo realizada em Contra Filon (lys.31.1-7).

Tribunal como espaço de formulação e crítica de teorias de controle social. Dois discursos apresentam o controle de grupos sociais como questão: sobre os escravos, Por Calias (lys.5), e sobre os metecos, Contra os mercadores de trigo (lys.22), nos quais o orador discute o impacto, para a ordem social ateniense, da condescendência a tais grupos quando eles infringem regras definidas pela polis.

Tribunal como espaço de produção e crítica da memória política. O discurso Contra Eratóstenes (lys.12) é exemplar: além de se utilizar largamente da narrativa para rememorar acontecimentos ocorridos durante o regime dos Trinta e a restauração da democracia, o orador, antecipando a estratégia de defesa do acusado que consistiria em associá-lo a Teramenes, líder dos oligarcas moderados entre os Trinta, faz uma incisiva narrativa contra a memória de moderação criada ao redor de Teramenes (que seria reproduzida posteriormente por Xenofonte e Aristóteles), negando assim a validade da (possível) estratégia de defesa.

\section{b) Retóricas da identidade e da memória}

O que é ser cidadão, e o que é ser meteco, e como estes seres aparecem nos discursos de Lísias? A historiografia tradicionalmente buscou (e encontrou) nas fontes 
atenienses dados objetivos para responder tais questões, dados estes que permitiram a listagem de direitos e deveres que constituem cidadãos e metecos como tais: cidadão é aquele que pode sentar-se na assembléia ou no conselho, exercer magistratura, conduzir ritos e cultos, ter propriedade da terra etc, e deve prestar serviços militares, pagar determinados impostos especiais etc; meteco é aquele que não pode exercer a política nos quadros institucionais da polis, cuja vida vale juridicamente menos que a de um cidadão, que deve pagar um imposto ligado ao seu status, o metoikion etc, mas é livre para exercer profissões e comercializar na ágora, pode contribuir com taxas especiais da cidade em troca de prestígio, e no limite ausentar-se quando quiser. Mas isto esgotaria o ser dos cidadãos, assim como o ser dos metecos? Tais dados objetos seriam realmente objetivos, ou seriam produtos de discursos inseridos em relações de poder (e contrapoder) que produzem tais seres? Por conta destas questões, antes da análise dos modos retóricos nos quais a questão da identidade de cidadãos e metecos aparecem nos discursos, será feita uma breve discussão do conceito de identidade tal como aparece nos estudos mais recentes, de modo a melhor matizar a problemática que será posta na análise dos discursos, o que poderia ser resumida como uma dialética entre o ser e o devir das identidades.

\section{A dialética ser-devir e a politica das identidades}

Os estudos sobre a questão da identidade realizados na segunda metade do século XX, oriundos principalmente da Sociologia e Filosofia, na França, e dos chamados Estudos Culturais, nos Estados Unidos, tenderam a enfatizar o caráter construído, não-essencial das identidades. Assim, se tradicionalmente as "identidades" eram vistas como coisas em si, objetivas e essenciais (um brasileiro é isso ou aquilo, uma mulher é isso ou aquilo), tais estudos procuraram demonstrar o movimento constitutivo, e portanto histórico, da criação de identidades: um brasileiro torna-se um brasileiro, ou seja, o ser brasileiro está inserido em uma histórica - passa-se, assim, da identidade como ser para a identidade como devir.

Deste ponto de vista, a identidade é inseparável da diferença: tornar-se algo ou alguém é diferenciar-se de outros, de outras identidades (também históricas). Um ateniense se torna um ateniense não sendo espartano, tebano, persa, egípcio - a identidade de ateniense, deste ponto de vista, se constrói pelo jogo das diferenças com 
outras identidades, e, na medida que esta construção é histórica, ela varia também de acordo com a variação das representações da diferença. Daí que os estudos mais recentes sobre a questão, em particular ligados às correntes foucaultianas, preferem utilizar o termo identificação ao termo identidade, e diferenciação a diferença.

Os estudos sobre a identidade, particularmente dos Estudos Culturais realizados nos Estados Unidos, têm sido muito criticados por enfatizar o caráter fluido, fragmentário, volátil das identidades: seus autores têm sido acusados de aceitar acriticamente o discurso da globalização, de aderir ao modismo intelectual das identidades, de fazer desaparecer os conflitos sociais etc. Estas críticas, no limite, fazem com que determinados autores aconselhem o abandono do termo identidade: é o caso, por exemplo, de R. Brubaker (2001), que, diante das ambigüidades do termo, propõe que se lance mão de outras referências conceituais para a discussão de questões até então monopolizadas pelos estudos de identidade.

Certamente, estas críticas são adequadas para um amplo espectro de livros e artigos. No entanto, gostaria de argumentar que, no caso da discussão da participação política dos metecos atenienses, algumas das categorias gestadas nos estudos sobre a identidade são indispensáveis para uma crítica das visões dominantes sobre o tema, particularmente as categorias de posição de sujeito e situação ${ }^{39}$.

Retomemos a questão da identificação como processo histórico. A identificação se dá por meio da diferenciação: torna-se o que se é ao tornar-se o que não se é - estes dois movimentos são indissociáveis. No entanto, o processo não se limita à eterna e indefinida mutabilidade e fluidez: o processo tende a se fixar em identidades e diferenças, que assumem uma aparência objetiva, essencial, ahistórica. Estas fixações, certamente, são reproduzidas socialmente, constituindo parte do trabalho morto da sociedade: as identidades de mulher, de brasileiro, de ateniense, são herdadas não em sua mutabilidade, mas justamente em sua fixação. A questão aqui é, portanto, analisar os modos pelos quais estas identidades mudam, e quais são as situações que as fazem se cristalizar novamente, ou seja, é preciso dialetizar o processo de cristalização/mutação da construção das identidades. É por meio desta dialética que se descobrem as relações

\footnotetext{
39 Estas categorias fazem parte daquelas propostas por Brubaker (2001), que, no entanto, falha em demonstrar sua filiação nos estudos foucaultianos e sociológicos que se dedicaram, justamente, à questão da identidade. O autor crítica o (mal) uso do termo, mas não o próprio conceito, o que confere ares de aconselhamento acadêmico ao seu artigo.
} 
de poder que produzem tanto a fixação quanto a mutação das identidades: segundo Tomaz Tadeu da Silva,

a afirmação da identidade e a marcação da diferença implicam, sempre, as operações de incluir e excluir. Como vimos, dizer "o que somos" significa também dizer "o que não somos". A identidade e a diferença se traduzem, assim, em declarações sobre quem pertence e quem não pertence, sobre quem está incluído e quem não está incluído. [...] Essa demarcação de fronteiras, essa separação e distinção, supõem e, ao mesmo tempo, afirmam e reafirmam relações de poder. [...] Os pronomes "nós" e "eles" não são, aqui, simples categorias e distinções gramaticais, mas evidentes marcadores de posições-de-sujeito fortemente marcadas por relações de poder (SILVA, 2000, p. 82).

A noção de posição-de-sujeito é central. Para além de uma contradição entre objetividade e subjetividade, esta noção procura dialetizar as imposições sociais ao indivíduo e os seus desejos e vontades: a posição-de-sujeito é o lugar, construído discursivamente, a partir do qual o agente se posiciona e fala. Como definir este agente e esta agência social? Mais do que "indivíduo", cuja liberdade é pressuposta e a ação social é vista como uma série de escolhas (racionais ou não), seria mais adequado, deste ponto de vista, utilizar a categoria "sujeito", em seu duplo sentido: de agentes e de pacientes de uma ação, sujeitos assujeitados. Dessa maneira, a questão da liberdade não se coloca na oposição indivíduo e sociedade, mas na maneira como o sujeito se constitui e é constituído.

Elemento central neste processo são as formas de normalização (CANGUILHEM, 2002). As identidades normais, impostas e repostas socialmente, são produtos e produtoras de relações de poder: a normalização como a eleição de "uma identidade específica como o parâmetro em relação ao qual as outras identidades são avaliadas e hierarquizadas" (SILVA, 2000, p. 83). Ora, certamente, a normalização não é uma via de mão única, e pressupõe ao menos uma contradição entre os poderes que se chocam em sua constituição. Encontrar os momentos, as situações específicas em que estas relações de poder produtoras de identidades e de contra-identidades, de normas e anormalidades, poderia abrir caminhos frutíferos para se pensar as identidades: situação simultaneamente como lugar, sítio, onde o sujeito se encontra em relação com outros sujeitos, representações, determinações, possibilidades etc; e como tempo, momento, 
quando as identidades são postas em questão seja para serem repetidas, seja para serem $\operatorname{alteradas}^{40}$.

Este é o ponto em que é impossível dissociar a questão das identidades da questão da política, tanto no sentido de produção das identidades (pelo poder e pelo contra-poder) seja na associação de certas identidades a certas posturas políticas. A discussão do tema das identidades nos discursos de Lísias, a seguir, procura analisar os modos (retóricos) pelos quais as identidades de cidadãos e de metecos são construídas e quais suas relações com as questões políticas atenienses, em particular a oposição entre democracia e oligarquia. A estratégia utilizada é analisar esta questão nos discursos que se associam, direta ou indiretamente, à situação crítica da restauração democrática de 403, quando as identidades de cidadãos e metecos são confrontadas por uma série de diferenciações antes inexistentes: (1) entre aqueles que ficaram na asty, os democratas apáticos e os oligarcas ativos; (2) entre os que saíram, os que o fizeram por vontade própria e os exilados pelos Trinta; (3) entre os exilados, os que retornaram junto com os democratas restauradores e os que retornaram apenas após a pacificação; (4) entre os retornados, os que respeitaram a democracia e os que se corromperam; entre outras. E vale lembrar que, no contexto judiciário específico dos discursos, onde estas diferenciações serão engajadas, não se trata do "direito à diferença" - as normas sociais e suas negociações exercerão o papel de estratégia retórica na definição seja da carreira, seja da própria sobrevivência do litigante.

\section{Identidades ético-politicas atenienses: cidadãos e metecos}

A historiografia foi enfática ao relacionar a construção da democracia e a instituição da metoikia, relação que traz a problemática da construção do devir "cidadão na democracia" em sua relação com a construção do devir "meteco na democracia". A identidade dos metecos na democracia apresentava dificuldades específicas para a constituição da identidade cívica, diferente das criadas pela identidade de mulheres e escravos: o meteco é aquele que é livre como o cidadão, que trabalha ao seu lado em

40 Para o caráter espaçotemporal da noção de situação, cf. "Teoria dos momentos e construção de situações", publicado na Internationale Situationniste de junho de 1960, traduzida para o português em JACQUES (2003, pp. 121-2) 
construções públicas, com ele que participa de banquetes e clubes, e que, se visto na rua, não se pode perceber que não é um cidadão. Entre livre e escravo, o estatuto do meteco já foi definido como um "terceiro estado" (WHITEHEAD, 1977, p. 69).

Mas como se dá o jogo das identificações/diferenciações nos discursos de Lísias? Para desenvolver esta questão, será utilizada a estratégia de analisar discursos que fazem menção a cidadãos e metecos e os julguem a partir de modelos éticos e morais do que deve ser e o que não deve ser um cidadão e um meteco; não se trata de se definir se tal ou tal personagem era de um fato um bom ou mau cidadão ou meteco, mas de identificar quais argumentos presentes no discurso são utilizados pelo orador como critérios éticos. Tomaremos, de início, dois discursos que apresentam interessantes paralelismos: Sobre a propriedade do irmão de Nícias (lys.18) e Contra Hippotherses (lys.fr.I).

O discurso Sobre a propriedade do irmão de Nícias: Epílogo, é uma defesa contra um processo de confisco da propriedade e perda dos direitos cívicos impetrado, por um certo Poliochus, contra uma das famílias mais famosas de Atenas: Nícias é o conhecido líder político comandante ateniense atestado em outras fontes. Os detalhes jurídicos deste discurso são bastante incertos ${ }^{41}$, assim como não se sabe se este é apenas um epílogo de um discurso maior (como indica o título no manuscrito) ou se trata-se do discurso integral, ou se somente o epílogo foi encomendado ao logógrafo; a data na qual foi proferido é provavelmente anterior à guerra coríntia, ou seja, anterior a $395 \mathrm{a}$. C.

O orador, que se identifica como filho de um dos irmãos de Nícias, Eucrates, não rebate as acusações feitas no processo (que nos são desconhecidas), mas utiliza a estratégia que construir o ethos da família cuja propriedade e direitos cívicos estão em jogo. Os familiares estão divididos em dois grupos: aqueles que eram adultos antes de 403 a. C. (Nícias, seus irmãos Eucrates e Diognetus, e seu filho Niceratus), e aqueles que eram crianças (o orador, um irmão seu não nomeado, seu primo Diomnestus, filho de Diognetus, e um primo de segundo grau, não nomeado, filho de Niceratus). Os benefícios feitos à polis por cada um dos adultos são enumerados pelo orador: Nícias, como general, capturou várias poleis e ergueu muitos troféus diante do inimigo, tendo sofrido muitos danos (como a morte da Sicília); Eucrates, eleito general após a derrota

\footnotetext{
${ }^{41}$ Sobre as dificuldades quanto às razões da acusação, procedimento utilizado, e processos anteriores, cf. Todd (2000, p. 192) e GERNET et BIZOT (1955, pp. 25-9).
} 
final em Aigos-Potamos, recusou-se a participar do golpe oligárquico e da composição dos Trinta, e, ao se opor à oligarquia, acabou sendo assassinado pelo regime, assim como Niceratus, filho de Nícias; Diognetus, tendo sido exilado da polis ainda durante a guerra do Peloponeso, segundo o orador pela ação de um sicofanta, recusou-se a lutar com os peloponésios contra Atenas (como muitos dos exilados fizeram), e quando os Trinta promoveram o retorno dos exilados, recusou-se a participar do governo e, quando da chegada do rei espartano Pausânias à Atenas ${ }^{42}$, entregou as crianças a este e convenceu-o da injustiça dos Trinta, convertendo-o à causa dos restauradores. Após esta enumeração, o orador discute tópicos obscuros sobre a anistia ${ }^{43}$, sobre os processos anteriores sobre sua propriedade e sobre o destino da propriedade se confiscada; por fim, o orador explora as contradições possíveis para a democracia caso seja privado da propriedade e dos direitos cívicos.

O orador apresenta o discurso não somente como uma defesa, mas também como uma espécie de heurística social: "nós estamos em julgamento não simplesmente pela nossa propriedade como também pelo nosso status cívico (politeia), para descobrir se nós teremos um lugar na polis sob a democracia recuperada" (18.1). Assim, o "lugar" dos familiares sobreviventes é marcado temporalmente, após a restauração da democracia: o julgamento revelará não somente se eles devem ou não ser cidadãos, como também qual é a relação da democracia com aqueles que a defenderam. Assim, a caracterização da conduta dos membros da família de Nícias é feita para promover uma contradição entre o respeito à democracia e o confisco de sua propriedade, por meio da ênfase na fidelidade democrática da família independente das circunstâncias. Após enumerar os serviços de Nícias à democracia antes de 403, o orador interpreta a causa das perseguições que Eucrates (irmão de Nícias) e Niceratus (filho de Nícias) sofreram pelos Trinta como o fato de que

\footnotetext{
${ }^{42}$ Que poria fim à guerra civil e auxiliaria a restauração da democracia e a anistia de 403, opondo-se ao navarco espartano Lisandro, que defendia a manutenção do regime dos Trinta; ver Introdução.

$43 \mathrm{O}$ orador retoma os acordos da anistia de 403 como um argumento para sua propriedade não ser confiscada: L. Gernet (GERNET;BIZOS, 1955, pp. 27-8) e S. Todd (2000, p. 192) vêem aí um indício, ao lado da presença de magistrados das finanças públicas (os sundikoi em 18.16) que o processo se origina em uma acusação contra Eucrates por mal uso de dinheiro público, que deveria ser anulada por a anistia se referia a esquecer não somente o que aconteceu durante o período do regime dos Trinta, mas qualquer crime anterior à 403 .
} 
os oligarcas eram conscientes de que toda a família era respeitada pela polis, pois eles enfrentaram perigo por vocês em muitos lugares, contribuíram com muitas eisforas e executaram liturgias excelentemente, e nunca se esquivaram de nenhuma outra tarefa que a polis os outorgou mas zelosamente cumpriram seus deveres. (18.7).

Assim, a lealdade democrática da família foi a causa de sua perseguição pela oligarquia. Como esta lealdade é marcada? Serviço militar, contribuições fisscais e respeito às determinações da polis. Esta lealdade seria continuada, após 403, pelos sobreviventes da perseguição:

Neste momento, Diomnestus, eu e meu irmão, nós três de um único oikos, estamos servindo como trierarcas ${ }^{44}$, e estamos contribuindo com eisforas, a partir desta propriedade, no momento em que a polis precisa de dinheiro. [...] Nada evitaria que nós fossemos os mais infelizes dos homens, senhores do júri, se depois de sermos deixados como órfãos sob os Trinta, nós fossemos privados de nossa propriedade sob a democracia. [...] Eu não tenho ninguém, senhores do júri, que eu pudesse trazer adiante para vos implorar em meu favor. Alguns de meus parentes morreram em guerra, depois de mostrarem ser homens honrados e fazerem a grandeza da polis. Outros morreram em favor da democracia e da sua liberdade, ao beber cicuta sob os Trinta. Como resultado, os méritos de nossa família e os desastres da polis são a causa de nosso isolamento. É correto que vocês devem relembrá-los e entusiasticamente ajudar-nos, percebendo que quem partilhou uma parte de seus sofrimentos durante a oligarquia merece receber benefícios de vocês durante a democracia. (18.21-2,24-5).

Assim, a alegação de lealdade democrática da família, que causou sua ruína durante a oligarquia, é usada no discurso como argumento que mostra a contradição de uma condenação na democracia: se a oligarquia os puniu por serem democratas, a democracia deveria honrá-los. O serviço militar, as contribuições físcais e o respeito à polis foram os motivos da perseguição na oligarquia; por seu turno, a democracia deveria honrar a família não somente pelas qualidades mencionadas acima, mas,

44 A trierarquia, que consistia num imposto compulsório aos cidadãos ricos para armarem navios de guerra, era cobrada sobre o oikos como um todo; afirmar que três membros do mesmo oikos eram trierarcas amplifica o caráter de entrega fiscal familiar, multiplicada por três. 
especialmente após a restauração, surge um novo critério de honra: ter partilhado os desastre da polis, ter lutado pela democracia. Mistura-se, na argumentação, polis, politeia e família - a família democrática é aquela que sofreu com a democracia e com a polis. O apelo à memória, aqui, funciona como meio de evitar a continuidade da injustiça oligárquica e reinstaurar a justiça democrática: sem a lembrança, não haveria para a família do orador qualquer diferença entre oligarquia e democracia.

Portanto, se de um lado a oligarquia é marcada pela falta de reconhecimento, pela ilegalidade e pela injustiça ${ }^{45}$, oposta à democracia, regime no qual os justos são reconhecidos pelos seus serviços. Mas, quanto à identidade democrática, ou seja, o devir do cidadão democrático, pode-se afirmar que a restauração de 403 marcou um momento no qual o devir foi transformado: se antes da restauração a afirmação dos serviços à polis (militares, fiscais, legais) bastava para se definir o cidadão democrata, após 403 um novo dado se torna fundamental - ter partilhado os sofrimentos da polis/democracia. Neste sentido, a memória se torna um elemento fundamental na composição deste devirdemocrático: se o comportamento justo é um elemento que se refere a situações mais ou menos regulares (o pagamento de impostos, as guerras etc), a participação nos sofrimentos da polis durante a oligarquia fazem referência à uma memória específica, a memória política de Atenas. E, considerando que o ethos é um dos elementos centrais da retórica judiciária ateniense, o recurso à memória política se torna uma estratégia fundamental na argumentação.

Em outro momento a relação entre memória política e identidade democrática será explorada mais profundamente, mas fica aqui indicada uma aporia para a constituição da identidade democrática do cidadão: como se posicionar diante do fato de que não-cidadãos, em particular metecos, compartilham dos mesmos elementos (comportamento justo, partilha dos sofrimentos, luta pela democracia) que compõem a identidade democrática?

Um outro discurso do Corpus apresenta paralelos interessantes ao discurso anterior. Trata-se do discurso Contra Hippotherses, encontrado em um papiro egípcio

\footnotetext{
45 Sem distinção social: no depoimento ao rei espartano Pausânias, Diognetus, irmão de Nícias, teria afirmado que "os Trinta estavam matando não os piores criminosos entre os cidadãos, mas aqueles que mais deveriam ser honrados devido ao seu nascimento, sua riqueza e seus méritos" (18.11), um argumento particularmente forte diante de um magistrado de uma oligarquia, mas talvez nem tanto diante de um tribunal democrático.
} 
datado provavelmente do século III d. C., que foi escrito para ser pronunciado em um processo que envolvia a propriedade do próprio Lísias. Assim como o discurso 18, o Contra Hippotherses está envolto em inúmeras dúvidas: não se sabe o procedimento utilizado, qual a causa nem mesmo quem está acusando e quem está se defendendo. Sabe-se que o discurso não foi pronunciado por Lísias (que aparece em terceira pessoa) e que se dirigia contra um certo Hippotherses, que retinha parte da propriedade de Lísias confiscada pelos Trinta. A datação é indefinida, mas provavelmente o processo ocorreu muito pouco tempo depois da anistia em 403.

Como o discurso 18, esse discurso faz uma listagem dos serviços do litigante à democracia (significativa contribuição financeira ao exército restaurador, contratação de mercenários), além de uma referência aos que, exilados pela democracia ainda durante a guerra do Peloponeso, traíram a polis e lutaram ao lado dos espartanos em Deceléia ${ }^{46}$. Mas o paralelo mais significativo é a semelhança de argumento: como o sobrinho de Nícias, o orador amigo de Lísias em Contra Hippotherses pede pela coerência da democracia restaurada:

Seria algo terrível, senhores do júri, se vocês, retornando do exílio por estarem sofrendo injustiças, fossem privados de sua propriedade como criminosos. E ainda vós teríeis todo direito de estar irritados com aqueles que compraram sua propriedade durante seu infortúnio: pois em primeiro lugar, os Trinta não a teriam vendido se não existissem compradores, e em segundo lugar... [linhas perdidas no papiro]

[...] Nós trazemos o assunto para vocês, para que, tendo ouvido o que Lísias e Hippotherses fizeram, dêem qualquer que seja o veredicto sobre o caso que quiserem, decidindo qual dos dois comportou-se melhor diante da polis. [...] Pois enquanto vocês eram prósperos, Lísias era o mais rico dos metecos, e quando o desastre ${ }^{47}$ tomou lugar, ele permaneceu aqui: ele não evitou nem mesmo a menor parte de seus infortúnios, mas foi ilegalmente privado de seu irmão e de uma considerável riqueza pelos Trinta. Depois que ele deixou

\footnotetext{
${ }^{46}$ Em lys.18.9, Diognetus é positivamente qualificado por, mesmo após ter sido exilado injustamente pela ação de sicofantas, ainda durante a Guerra do Peloponeso, estar entre os poucos exilados "que não lutaram contra a polis e não foram para Deceléia", fortificação ateniense então sob o poder dos peloponésios.

${ }^{47}$ Eufemismo para a derrota na batalha de Aigos-Potamos, que determinaria a capitulação de Atenas.
} 
Atenas como um exilado, ele enviou trezentos mercenários pelo seu retorno, e contribui com duzentas dracmas... [linhas perdidas no papiro] (frag.7.d-e $)^{48}$.

O paralelo com os argumentos do discurso 18 é evidente: Lísias, como meteco, partilhou da sorte e dos infortúnios da polis, respeitou suas leis, foi prejudicado pelo regime dos Trinta e contribuiu para a restauração da democracia. Daí o pedido de coerência: se a oligarquia injusta e ilegal dos Trinta o privou de sua propriedade, a democracia restaurada deve marcar uma ruptura com esta ilegalidade, honrando assim aqueles que partilharam seus infortúnios.

Mas, por baixo destas semelhanças, existe uma diferença radical: os sobrinhos e netos de Nícias, envolvidos no litígio do discurso 18, eram cidadãos; Lísias, antes e (exceto por um curto período) depois de 403, era um meteco. Mas seria esta separação tão radical assim? Nos discursos de Lísias aparece um jogo específico de identidade e diferença que faz com que o bom meteco se aproxime do cidadão democrata em suas relações com a polis, e ambos se afastem do mau cidadão, associado à oligarquia. $\mathrm{O}$ devir-oligarca do mau cidadão é mencionado nos demais discursos a partir de duas marcações identitárias coletivas: aqueles que ficaram em Atenas e apoiaram o regime dos Trinta (como aparece em nos discursos 13, 16, 25 e 26) e aqueles que, tendo participado das lutas pela restauração, utilizaram isto como argumentos para desrespeitar a democracia (como aparece nos discursos 25, 28 e 29). Uma terceira marcação pode ser citada, que aparece em apenas um discurso, o Contra Filon (lys.31): aqueles que não partilham dos infortúnios da polis, ausentando-se no perigo, e retornando quando a situação se estabiliza - a comparação da argumentação da acusação a Filon dá mais força ao paralelismo entre o Lísias do Contra Hippotherses e os parente do Sobre a propriedade do irmão de Nícias.

Esta associação entre os metecos (que apoiaram a restauração) e a democracia não seria também política, a despeito da restrição institucional aos não-cidadãos, como enfatiza a historiografia? O fato é que o estatuto jurídico, cidadãos e metecos, não é um obstáculo para a construção identitária presente nos discursos de Lísias - o bom democrata pode ser tanto cidadão quanto meteco, basta que corresponda ao devirdemocrático: serviços militares e fiscais, respeito às leis, e, após 403, ter apoiado a democracia durante o regime oligárquico.

\footnotetext{
${ }^{48}$ Numeração de acordo com Todd (2000).
} 


\section{Seria o meteco um "democrata subordinado"?}

A historiadora italiana C. Bearzot, discutindo o topos da apragmosune (não envolvimento ativo na esfera pública, como exercício de magistraturas, assento no conselho, nos tribunais etc) nos discursos de Lísias, chega a conclusões interessantes. Para a autora, a ser apragmon, no caso de cidadãos, pode ser um argumento positivo ou negativo: no caso de cidadãos acusados de serem oligarcas, ou de ter participado no regime dos Trinta, a alegação de apragmosune é positiva pois é melhor para a democracia que aqueles com inclinações oligárquicas não participem ativamente da vida pública ateniense, mas contribuam financeiramente pelas liturgias e demais taxas; mas no caso dos cidadãos que se afirmam democratas, a apragmosune se torna uma acusação, pois é dever do democrata participar da condução da polis (BEARZOT, 2001, pp. 72-3). Quando este topos se dirige a metecos, diz a autora, um elemento é adicionado no caráter do meteco:

Torna-se interessante notar que os casos lisianos de reivindicação de apragmosune por parte de metecos deixam emergir uma significativa diferença de impostações a respeito daqueles [casos] que visam cidadãos. Diversamente do cidadão que se declara apragmon, de fato, o meteco que precisa se autorepresentar de forma análoga não se limita a afirmar a próprio mérito o fato de conduzir uma vida retirada e de contribuir generosamente às despesas comuns, mas acrescenta à sua autorepresentação uma forte ênfase na própria devoção à democracia. (BEARZOT, 2001, p. 74).

A autora analisa brevemente então cinco discursos de Lísias $(5,12,22,31$, f.I) para demonstrar esta tese, concluindo que os metecos respeitavam o lugar social determinado para eles pelos cidadãos, mas que assumiam para si uma devoção democrática maior que àquela dos cidadãos ricos ou suspeitos de apoiar a oligarquia, $\mathrm{o}$ que faria com que

O meteco lisiano sente-se certamente melhor - e como se apresenta, sem meios termos, em tribunal - do cidadão apragmon: melhor porque alheio a todo sentido de estranhamento a respeito do koinon democrático, e assim profundamente inserido, ainda que em um papel subordinado a qual humilde aceitação constitui, por sua vez, o sinal da adesão profunda a um sistema de 
valores que se pretende fazer precisamente sem reservas. (BEARZOT, 2001, p. $80)$.

Conforme foi dito na analise do fragmento Contra Hippotherses, no qual o próprio Lísias aparece contribuindo (financeiramente, militarmente) para a restauração democrática, concordamos com a autora que a associação entre metecos e cidadãos democratas pode ter sido entendida, ao menos pelo meteco, como mais forte do que a cidadãos democratas e cidadãos apragmon, ou seja, de "devoção democrata suspeita"; assim como concordamos que nos discursos de Lísias existe a criação própria da identidade democrática do meteco. Mas, na análise feita acima, existem elementos que vão além da afirmação da autora quanto à aceitação do "papel subordinado" do meteco, e portanto o meteco democrata era necessariamente um apragmon, ainda que devoto: ora, uma coisa é contribuir com liturgias, eisforias e demais taxas nos períodos de normalidade democrática, que era prática comum entre metecos e cidadãos ricos, e ambos seriam considerados como apragmon; outra coisa radicalmente diferente é contribuir, com dinheiro e soldados, para um exército que procura derrubar um regime oligárquico e restaurar a democracia - não seria isso participação política ativa de um meteco, pela democracia? No discurso Contra Hippotherses, utilizados pela autora para demonstrar a apragmosune do meteco ideal, a argumentação vai justamente no sentido contrário: é por ter participado ativamente da esfera pública (a mudança no regime) que Lísias deve ser honrado.

O fato de ter misturado estas duas contribuições (para a democracia em tempos normais, e pela democracia em tempos de excessão) fez com que a autora transformasse a imagem do "meteco ideal subordinado" de problema historiográfico em pressuposto ${ }^{49}$, ao menos na leitura do Contra Hippotherses". Mas o "meteco democrata ativo" só

\footnotetext{
${ }^{49} \mathrm{Cf}$. a crítica à visão contratual dos metecos de Baslez, v. Capítulo 2.

${ }^{50}$ No caso dos outros discursos analisados pela autora a imagem do "meteco subordinado" é menos problemática, ainda que não inquestionável: por exemplo, a autora analisa o discurso Por Calias, que trata de um meteco acusado pelos seus escravos de cometer sacrilégios - a argumentação de defesa parte do comportamento ordeiro e dos bons serviços de Calias à polis, e termina associando Calias a todos os livres que correm perigo diante da liberalidade dada aos escravos. Ora, este último trecho é revelador: a defesa de Calias, um meteco, exerce (ou se pretende) uma defesa ativa de todos os livres contra os escravos - o que seria isso senão participação ativa na vida pública?
} 
apareceria em um discurso, ou melhor, em um fragmento de um discurso no Corpus? Para melhor encaminhar a crítica a esta visão do "meteco subordinado", e assim matizar a problemática da participação política ativa do meteco na constituição de seu devirdemocrático, passemos à questão da produção da memória política ateniense relativa aos acontecimentos de 403.

\section{Das políticas da identidade à memória}

A questão da memória política da restauração de 403 em Atenas tem recebido, nos últimos anos, diversos estudos, entre os quais destacam-se os de N. Loraux (2005), de A. Wolpert (2002) e de C. Bearzot (2006). Mas antes de abordarmos a questão da memória política da restauração e da anistia tal qual aparece nos discursos de Lísias, e quais suas implicações para a construção das identidades de cidadãos e metecos, façamos uma brevíssima discussão sobre a inserção social da memória, de modo a especificar a problemática que será direcionada aos textos.

Os estudos de memória, realizados num espectro de disciplinas que vai da Neurologia à Filosofia, apresenta uma tão grande quantidade de questões que seria praticamente impossível articulá-las em uma abordagem unitária. Interessam-nos aqui, particularmente, as questões relativas à produção social da memória a partir do ponto de vista da História Social, que é um dos temas abordados em um texto de U. T. B. de Meneses, intitulado “A História, cativa da memória? Para um mapeamento da memória no campo das Ciências Sociais" (1992). Da argumentação do autor, reteremos aqui somente três idéias principais: a memória não está cristalizada nem no passado, nem nos objetos referenciais da memória - a memória é um fenômeno social, e como tal está permanentemente em construção, respondendo a solicitações do presente; a memória não se limita a mecanismos de retenção/depósito/armazenamento, mas é também seleção e descarte - daí a importância do esquecimento e dos problemas de seleção social do que deve ser lembrado e do que deve ser esquecido; os processos de construção e descarte, ou seja, de rememoração e esquecimento do passado, formam uma problemática social que remetem a sistemas mnemônicos, aos conteúdos da memória e aos agentes e suas práticas - a gestão da memória não pode ser reificada como fato em si, mas incluída dentro uma dinâmica social, aí incluso dominações e conflitos envolvendo e sendo envolvidos pela memória. 
Como se produzia, pois, a memória política a respeito do regime dos Trinta e da restauração de 403? Quais conteúdos deveriam ser lembrados, quais deveriam ser esquecidos? Quais eram os lugares de produção desta memória, quais seus sujeitos? Quais as mudanças históricas observáveis na produção desta memória ao longo dos anos posteriores a 403? A hipótese que será argumentada é de que os discursos de Lísias que fazem referência a estes acontecimentos carregam uma proposta específica de produção da memória, contrária aos acordos de "esquecimento" da anistia: diversos discursos lembram dos "males passados", e esta lembrança se pretende uma defesa da democracia. Além disso, os discursos de Lísias são indício de que os tribunais e os discursos jurídicos eram lugares de produção da memória, na qual os metecos ocupam duas posições ao menos: uma explícita, de ter participado da restauração democrática aos lado dos cidadãos; outra, implícita, na forma própria do logógrafo que participa da construção discursiva da memória por meio de discursos pronunciados por cidadãos. Passemos pois à questão da anistia de 403/2, e seu juramento de "não lembrar os males passados" (me mnesikakein).

A historiadora francesa Nicole Loraux (2005) dedicou um estudo sobre este tema, que procura unir as abordagens antropológicas, ligadas às estruturas e ao repetitivo, a abordagens históricas, ligadas ao acontecimento e ao singular. Para a autora, o esquecimento instituído pela anistia articulava o antropológico e o histórico das polis de Atenas na medida em que o que estava em discussão era a unidade e a divisão da polis. A stasis, a guerra civil fruto da divisão da polis em partidos opostos: a ruptura do corpo cívico, era entendida como a mais funesta das guerras que, ao contrário da guerra contra o inimigo externo, não garantiria a bela morte. Sendo assim, os momentos de stasis, tanto potenciais, como o debate na Assembléia que opõe idéias, quanto reais, como a guerra pela restauração da democracia, são anulados por mecanismos culturais de ocultamento: no caso da divisão do debate em Assembléia, a regra da vitória da maioria é amenizada com a idéia da unanimidade justa; no caso da restauração, o esquecimento passa a ser o princípio de reconciliação. Entretanto, como a própria autora aponta, o esquecimento da guerra civil, dos excessos dos Trinta, das condutas oligárquicas, não era aceito por todos: os discursos de Lísias são prova desta resistência.

Os discursos de Lísias lembram os males passados, mas de modo algum a memória política tem um estatuto neutro: pode se fazer bom ou mau uso dela. 
Tomaremos dois dos mais significativos: sobre o bom uso da memória como defesa da democracia, será analisado o discurso Contra Evandro (lys.26); para uma crítica do uso da memória como estratégia oligárquica, será analisado o discurso Contra Érgocles (lys. 28).

\section{Usos da memória, entre a democracia e a oligarquia}

Fato raro no Corpus, existe certeza quanto a alguns aspectos formais do discurso Contra Evandro (lys.26): datado do penúltima dia do segundo ano da 99a olimpíada (meados de 382), fazia parte de uma dokimasia, ou seja, um procedimento jurídico que encaminhava o exame prévio pelo qual deve passar todo candidato de uma magistratura ou assento no Conselho; neste caso, é a dokimasia de um certo Evandros para o cargo de arconte-epônimo, o qual, além da honra da nomeação do ano, garantia ao ocupante a direção de rituais religiosas, do cuidado com os órfãos e viúvas, além de um assento vitalício como membro do tribunal do Areópago; além disso, sabe-se o resultado do julgamento: a lista de arcontes epônimos conta com um Evandro no ano de 382, o que segundo os estudiosos, indicaria que o acusado no presente discurso conseguiu passar pela dokimasia. O orador se diz amigo do candidato que foi recusado na dokimasia anterior (Leodamas ${ }^{51}$ ), apesar de afirmar que não se trata de uma questão pessoal: é em nome das vítimas dos Trinta que o orador fala, mais de vinte anos depois da restauração democrática. Mas, apesar destas (raras) certezas, falta um elemento fundamental: a acusação que o orador faz a Evandro. Existem algumas indicações vagas, como a que Evandros estará envolvido em um assassinato, e portanto seria impuro para assumir tão importante cargo; mas, na maior parte do tempo, o discurso procura associar o acusado ao regime dos Trinta, argumentando a inadequação de um antigo apoiador da oligarquia como magistrado da democracia ${ }^{52}$. Para isso, o orador rememora a oligarquia dos Trinta, a todo momento inserindo Evandro em suas ações: antecipando a defesa de Evandro, diz orador

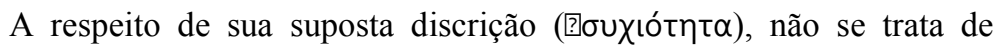
examinar se ele é respeitável ( $\sigma \omega ́ \phi \omega v)$ agora, quando ele não tem a permissão

\footnotetext{
${ }^{51}$ Existe uma referência à dokimasia de Leodamas em Aristóteles, Retórica, II, 23.

52 Não se sabe se, no início do discurso, que falta no manuscrito, alguma acusação mais formal foi realizada.
} 


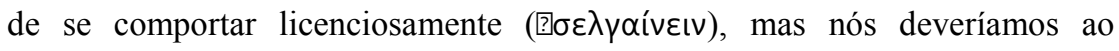
contrário olhar para o tempo em que ele poderia comportar-se como ele quisesse, e ele escolheu tomar parte em um regime ilegal [a oligarquia dos Trinta]. O fato de que ele não esteja cometendo crimes no presente deve-se àqueles que evitam isso. (26.5).

Assim, a oligarquia é marcada pela licenciosidade ${ }^{53}$, enquanto a democracia evita o comportamento criminoso de seus membros. Esta oposição é uma constante nos relatos da oligarquia presentes nos discursos de Lísias: assim, a narrativa dos crimes dos Trinta em Contra Eratóstenes (12.5-23), no relato de Diognetus a Pausânias em Sobre a propriedade do irmão de Nícias (18.11), e particularmente em um trecho do Defesa a uma acusação de subverter a democracia, quando o orador caracteriza a oligarquia dos Trinta como um período em que era "fácil para qualquer um que quisesse cometer crimes" (25.16). Assim, no presente discurso, a licenciosidade da oligarquia se torna a prova da licenciosidade de Evandro: se a democracia, cujo base era a legalidade, impedia o comportamento criminoso, o período onde a lei não era respeitada constitui o teste fundamental da honestidade dos indivíduos - ter sido honesto na oligarquia é uma prova de que se é honesto sempre, enquanto ser honesto na democracia apenas prova que a democracia é eficiente ${ }^{54}$.

A partir deste pressuposto (legalidade eficiente na democracia/licenciosidade e liberdade de escolha do indivíduo na oligarquia), o orador acusa Evandro de ter participado da cavalaria e do Conselho durante o regime dos Trinta. Esta participação ativa na oligarquia funciona, no discurso, para demonstrar a contradição, no discurso, se Evandro tornar-se arconte: como a democracia poderia conceder uma magistratura a um oligarca? Neste ponto, o orador elabora uma interpretação da própria função da dokimasia pós 403:

Tenham em mente que a pessoa que criou a lei sobre a dokimasia o fez não menos devido àqueles que haviam exercido magistraturas sob a oligarquia. Ele pensou que seria uma coisa terrível se aqueles por cuja culpa a democracia foi derrubada novamente ocupassem cargos sob a constituição e

\footnotetext{
${ }^{53}$ Comparar, por exemplo, com 12.5-23, 18.11, 25

${ }^{54}$ Vale notar que este argumento inverte a tradicional crítica oligárquica ateniense, como aquela presente na Constituição dos Atenienses de Pseudo-Xenofonte, segundo a qual a marca da democracia era a indisciplina.
} 
ganhassem controle sobre as leis e sobre a polis, as quais eles de um modo tão vergonhoso e tão terrível maltrataram quando delas se encarregaram previamente. Portanto, seria errado tomar a dokimasia levemente ou pensar que se trata de um assunto pequeno e não guardar atenção com ela. Ao contrário, vocês devem protegê-la, pois é da designação regular de cada magistrado que depende a segurança da democracia e de toda a constituição. (26.9).

Que esta ou outra foi a intenção do proponente da lei da dokimasia não será tratado aqui; porém, é preciso atentar para a função deste exame prévio: fundamento da segurança da democracia e da politeia, a dokimasia é um exercício institucional de memória política. Momento de lembrar dos males passados (mnesikakein, portanto), a dokimasia evitaria incoerências que destruiriam a democracia, como, por exemplo, que um cidadão, que na época da oligarquia foi responsável (direta ou indiretamente) pela morte de cidadãos honestos, se tornasse o responsável por proteger os órfãos destes cidadãos honestos (26.12).

Mas este momento institucional da memória política, de se lembrar os males passados, a despeito do acordo de me mnesikakein da anistia, se voltaria contra todos aqueles que permaneceram na cidade (asty) durante o regime dos Trinta? O orador antecipa o argumento de defesa:

Eu ouço que ele [Evandro] argumentará que a dokimasia não é sobre ele somente para sobre todos aqueles que permaneceram na asty, e ele relembrará dos juramentos e acordos, na esperança de que estes o ajudarão a ganhar a aprovação daqueles que permaneceram na asty. Em favor da democracia, eu gostaria de responder brevemente como segue: o demos não tem a mesma atitude diante de todos aqueles que permaneceram na asty; pelo contrário, no caso daqueles que cometeram crimes como este, o demos tem a atitude que eu digo que é necessária; mas diante do restante, tem a atitude oposta. [...] O demos acredita que é devido a homens como esses [os criminosos que permaneceram, como Evandro e seus apoiadores] que pessoas foram presas e executadas durante aquele período [dos Trinta], e que é devido aos outros que pessoas escaparam, porque se todos tivessem compartilhado a mesma atitude, nem o exílio nem a restauração nem qualquer dos eventos passados teriam atingido a polis. (26.16-18).

E sobre aqueles que permaneceram na asty mas ajudaram os exilados a retornar, o orador diz que 
Eles preferiram partilhar a politeia com os exilados que retornavam mais do que ser escravos para os espartanos aliados aos Trinta. É por isso que o demos tem honrado eles com as maiores honras, acima dos exilados. [...] É a respeito daqueles que cometeram muitos crimes que o demos estabeleceu dokimasiai, mas fez os acordos pelo bem daqueles que não cometeram nenhum crime. Este é o resumo da minha resposta em favor do demos. (26.19-20)

Portanto, lembra-se não só dos "males passados", mas dos serviços à democracia feitos por alguns daqueles que permaneceram na asty. Neste sentido, a possível alegação da defesa de Evandro de que a lembrança dos males passados, promovida pelo discurso, é contrária aos juramentos assumidos em 403, é contornada pelo orador por meio da questão da distribuição de honras: os que permaneceram e ajudaram a restauração da democracia teriam sido mais honrados que os próprios exilados, justamente porque, retomando um argumento anterior, a oligarquia não os teria impedido de cometer crimes. Lembrar dos males passados é criar mais uma diferença identitária: não somente "os que foram exilados" e "os que permaneceram", como também, entre os que permaneceram, os "justos" e os "injustos". E nesta equação, os justos que permaneceram estariam acima dos que foram exilados.

No entanto, a acreditar nas listas de arcontes epônimos, Evandro conseguiu pasar pela dokimasia. Os estudiosos interpretam este sucesso a partir de três razões: a primeira, a data quando ocorreu esta dokimasia, pois, tendo ocorrido dois dias antes da posse do cargo, o reinício do processo de sorteio e dokimasiai para se escolher um novo arconte configuraria um sacrilégio, pois no primeiro dia do ano ocorreria uma festa em homenagem a Zeus, a qual deveria ser presidida pelo arconte; a segunda, a possível qualidade da defesa de Evandro; e a terceira, mais comum, o tempo transcorrido entre os eventos rememorados (404/3) e a dokimasia de Evandro (382), mais de vinte anos, o que teria feito com que os antigos ressentimentos fossem amenizados - isto explicaria o esforço do orador em teorizar a dokimasia como lembrança institucional, para reforçar os ressentimentos assentados. Possivelmente, como afirma Todd (2000, p. 273) concorreram para a vitória de Evandro as três razões; de qualquer maneira, o discurso Contra Evandro se coloca como uma reinterpretação não só da anistia de 403, como também do procedimento da dokimasia como lembrança institucional e da própria história de Atenas durante a oligarquia dos Trinta. 
No entanto, a memória pode se prestar também à subversão da democracia: é o caso de uma alegação contra a qual se levanta o discurso Contra Érgocles: Epílogo (lys.28). Datado de 388, o procedimento adotado provavelmente foi a eisangelia, ou deposição de um magistrado, pronunciado diante não do tribunal, mas da própria Assembléia. A história do discurso relaciona-se com a expedição naval de Trasíbulo (o mesmo general que liderou a restauração democrática em 403) durante a Guerra Coríntia (395-87) nas ilhas do Egeu e na costa da Ásia Menor, interpretada na época como uma tentativa de reconstrução do império ateniense perdido com a derrota na Guerra do Peloponeso. Apesar de alguns sucessos no restabelecimento no fornecimento de trigo e de algumas rendas imperiais, a expedição gerou uma crise diplomática envolvendo inclusive o rei persa: Trasíbulo, que morreu durante uma revolta da cidade de Aspendus, em 389, seria acusado, junto de seus generais, de ter traído aliados, saqueados diversas cidades e se enriquecido ilicitamente. Um de seus generais, Érgocles, é acusado de corrupção, peculato com o tesouro ateniense e abuso contra aliados. Sabe-se o resultado do julgamento por meio de outro discurso de Lísias, Contra Filócrates (lys.29), um dos aliados de Érgocles: neste discurso, Filócrates é acusado de ter retido e escondido o dinheiro público teria roubado do tesouro ateniense, e que estava desaparecido desde a execução de Érgocles.

Este discurso (assim como o seguinte, lys.29) tem uma importância histórica evidente, pois se insere no contexto da reconstrução imperial de Atenas diante de uma grave crise econômica. No entanto, aqui será retomada apenas o aspecto do uso da memória neste discurso, ou melhor, o (suposto) uso da memória feito pelo acusado. É por meio da antecipação da defesa que a memória aparece:

Eu imagino, atenienses, que sobre o caso de Halicarnasso ${ }^{55}$, sobre seu comando na expedição, assim como sobre seus atos, Érgocles não tentará se justificar; pelo contrário, ele afirmará que é um dos retornados do exile de File $^{56}$, que é um democrata, e que ele compartilhou nos seus perigos. Entretanto, eu não tomaria a mesma atitude diante de todos eles, atenienses.

${ }^{55}$ Os habitantes de Halicarnasso teria reclamado de uma pilhagem promovida pela expedição de Trasíbulo.

${ }^{56}$ Esta referência a File, segundo Todd (2000, p. 291), seria um indício de que Érgocles estaria entre os primeiros que lutaram pela restauração; uma referência ao Pireu indicaria que ele só tomou parte quando a luta já estava iniciada. 


\begin{abstract}
Aqueles que, por desejo de liberdade, porque respeito à lei, e por ódio aos os criminosos, compartilharam seus perigos, eu não os vejo como maus cidadãos, e eu certamente não afirmo que seria injusto que seu exílio fosse tomado em conta. Mas no caso daqueles que, depois de retornar do exílio, cometem em plena democracia crimes contra o povo e tornaram maiores suas propriedades

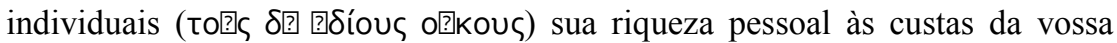
propriedade, merecem a sua cólera muito mais do que os Trinta. Os Trinta foram nomeado para fazer nada menos do que o mal sobre vocês, qualquer que fosse o meio, enquanto vocês se tornaram confiantes com estas pessoas [Érgocles e aliados] para que eles assegurassem à polis a liberdade e a grandeza. (28.12-14).
\end{abstract}

A contra-argumentação se dá, aqui, pela refutação do uso da memória: a lembrança da participação do acusado na restauração de 403 não justifica seus crimes. Entretanto, não é pelo esquecimento que argumenta o orador: pelo contrário, o orador retoma uma outra memória, posterior à restauração, e que cria uma diferenciação entre os que retornaram do exílio: de um lado, os que, desejando a liberdade, respeitando a lei e odiando os criminosos, restauraram a democracia; de outro, os que cometeram crimes na democracia e se enriqueceram as custas do povo. Aos primeiros, a memória positiva do exílio e do retorno é permitida; aos últimos, esta memória é negada e uma outra, pejorativa, pós-restauração, é atribuída.

E, mais do que isso, o orador afirma que os magistrados que são maus democratas são piores que os próprios Trinta, justamente pela inversão: se os Trinta eram contrários à democracia e conseqüentemente ao povo, os magistrados, cujo poder foi concedido pelo povo, tem uma maior responsabilidade. Subjacente a este argumento a identificação entre democracia e povo, identificação que deve ser mediada pelo respeito à lei: muito mais do que definir a democracia pelo governo da maioria, numa referência puramente numérica, o orador define a democracia como o regime o respeito ao povo prevalece, por oposição à oligarquia onde o povo é visto como inimigo declarado dos magistrados.

Ainda um elemento é utilizado na associação do acusado com a oligarquia: a corrupção. Para enfatizar o caráter exemplar da condenação de Érgocles, o orador afirma:

Tenham em mente, atenienses, que não é somente Érgocles que está em julgamento, mas a polis inteira. Hoje vocês demonstrarão para seus magistrados se eles devem ou não comportar-se de um modo justo, ou 
apropriar-se da sua propriedade tanto quanto possível enquanto preparam uma fuga, assim como estes homens [Érgocles e aliados] estão tentando fazer agora. Vocês devem estar completamente conscientes disto, atenienses: se alguém trai poleis, ou clama o direito de roubar dinheiro ou receber propinas, quando seus negócios estão em tal dificuldade ${ }^{57}$, ele também entregará as muralhas e navios ao inimigo, e estabelecerá uma oligarquia no lugar da democracia. (lys.28.1011).

Assim, a corrupção dos democratas é vista como um comportamento que leva à oligarquia: o orador repete as ações dos Trinta anteriores ao golpe, a saber, principalmente, a destruição das muralhas e a entrega dos navios a Esparta, ações que foram tomadas, segundo diversas fontes ${ }^{58}$, sob a direção do então maior líder oligárquico, Teramenes. Reforça-se, portanto, a oposição entre a ética oligárquica (corrupção, desrespeito às leis, ódio ao povo) e a ética democrática (legalidade, serviço ao povo). Esta inversão ética da corrupção da democracia cria o não-cidadão por excelência, para o qual o orador utiliza uma expressão significativa: aqueles que se corrompem na democracia "se tornam estranhos para a polis" (allotrious tes poleos autous hegesanto, 28.6).

Um interessante paralelo, cheio de oposições, pode ser estabelecido entre os dois discursos analisados acima, o Contra Evandro e o Contra Érgocles: enquanto o primeiro, para acusar um (suposto) oligarca que se diz democrata, cria dois subgrupos opostos entre aqueles que permaneceram na asty durante a oligarquia dos Trinta, o último, também para acusar um (suposto) oligarca que se diz democrata, cria dois subgrupos entre aqueles que retornaram do exílio em 403. Em ambas as estratégias, está a crítica e (re)produção da memória política ateniense por meio da criação de identidades específicas: os que permaneceram e foram contra a democracia; os que permaneceram e apoiaram a democracia; os que retornaram e respeitaram a democracia; e os que retornaram e não respeitaram a democracia. É evidente, portanto, que a relação

\footnotetext{
${ }^{57}$ Referência à crise financeira ateniense que perdura por mais de quinze anos após a perda do império. Cf. Gernet e Bizos (1955, p. 148, n.3).

58 Principalmente: Constituição de Atenas, caps. XXXV-XL, de Aristóteles; Helênicas, livro II, de Xenofonte; Contra Eratóstenes, de Lísias; e História Universal, XIV, de Diodoro Sículo.
} 
com a democracia é o vetor fundamental da produção das identidades a serem lembradas pela memória política, matizadas pela permanência ou não na asty.

\section{A lembrança dos metecos restauradores}

Mas, neste ponto, cabe questionar: qual é o lugar dos metecos nessa produção da memória política democrática tal qual é feita nos discursos de Lísias? A participação dos metecos na restauração de 403 é mencionada indiretamente em Contra Hippotheses (lys.frag.7), na medida em que é a participação do próprio Lísias que está em questão, e diretamente em Contra Filon (lys.31).

No primeiro, após listar os serviços de Lísias à causa dos restauradores (trezentos mercenários, duzentas dracmas do próprio dinheiro e mais dois talentos emprestados de um conhecido, Trasideus de Elis, que mantinha relações de xenia com Lísias), o orador afirma que Lísias "não recebeu qualquer favor ou recompensa em troca" (frag.7.f), mas, na peroração, afirma categoricamente que "Lísias merece receber a gratidão do demos, dado que ele tem sido um grande benfeitor" (frag.7.g). Qual é o fundamento para esta exigência de gratidão feita pelo orador? O segundo discurso, Contra Filon, traz indicações interessantes: a participação dos metecos é mencionada no contexto da discussão sobre o reconhecimento da polis diante daqueles que lutaram pela democracia:

Todos teriam razão em criticar vocês [membros do Conselho], se, tendo recompensado os metecos de uma maneira digna da polis por terem auxiliado a democracia além de seu dever, vocês não punirem meu oponente por ter traído a polis em oposição ao seu dever, ao menos com o tipo de

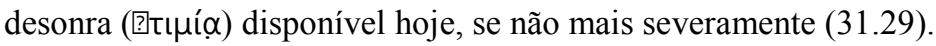

Aqui, pois, o orador faz uma atribuição de valor a partir do dever: o cidadão deve defender a democracia, enquanto o meteco não; se o meteco defende a democracia, ou seja, faz mais do que seu dever, merece ser honrado, o que aumenta a necessidade de punição sobre o cidadão que não cumpre seu dever. Atribuição paralela à encontrada no discurso Contra Evandro: aqueles que não cometeram crimes na oligarquia, ou seja, que cumpriram seu dever democrático mesmo quando este não era requerido, estão acima daqueles que cumprem seu dever apenas na democracia. Neste sentido, o "fazer mais do 
que o dever indicava" cria uma identidade, democrática, entre cidadãos e metecos, e talvez seja este mesmo raciocínio que orienta a exigência de gratidão presente em Contra Hippotherses.

Mas como a memória ateniense enfrenta esta aporia: cidadãos e metecos, lado a lado, na restauração democrática? Como enfrentar a irrupção do caráter político dos metecos? Nos anos imediatamente seguintes à restauração, alguns decretos envolvendo a concessão de recompensas aos metecos nos dá a dimensão que isto constituiu um debate público na polis: o meteco continua sendo meteco, mesmo tendo apoiado a democracia? Ora, a polis, após um período de indeterminação, na qual a própria cidadania foi concedida a todos os não-cidadãos que participaram da restauração, tomou a opção de conceder a cidadania apenas àqueles que participaram das lutas desde o primeiro momento, na tomada de File; quanto aos que entraram depois, seriam concedidas determinadas honras, como a isotelia, sustento para os órfãos etc (WHITEHEAD, 1977, p. 158). Certamente, a discussão sobre a concessão ou não da cidadania a metecos que participaram, em maior ou menor grau, da restauração, coloca em questão a própria definição da cidadania - não tornar os metecos cidadãos, mesmo aqueles que lutaram diretamente na restauração (após File), implica em reconhecer que a atividade política não é monopólio dos cidadãos. As implicações disto para a definição da própria polis serão discutidas em outro momento ${ }^{59}$; mas, aqui, vale recolocar a questão: como se lembrar da participação política dos metecos?

Como foi dito, apenas dois discursos do Corpus atribuído a Lísias fazem referência à essa participação, e sendo esta pesquisa limitada a tais discursos, esta questão demandaria uma maior pesquisa. No entanto, gostaria apenas de indicar uma passagem, em diversos sentidos paradoxal: o relato da revogação, por Arquino, em 403, do decreto de Trasíbulo (que concedia cidadania plena aos não-cidadãos) presente na Constituição de Atenas de Aristóteles, composta na segunda metade do século IV:

Concluída a reconciliação [...], os que haviam combatido ao lado dos Trinta mostravam-se receosos, e muitos que tencionavam emigrar [para Elêusis] adiavam a inscrição para os últimos dias, coisa que todos costumam fazer. Arquino, inteirado de seu número e pretendendo retê-los, cancelou os

${ }^{59}$ V. Capítulo 8. 
dias restantes para a inscrição, de maneira que muitos, apesar de contrariados, viram-se forçados a ficar, até virem a recuperar a confiança. E nisto Arquino parece ter agido com bom civismo, e também quando ele posteriormente moveu um processo por ilegalidade contra o decreto de Trasíbulo, no qual se concedia cidadania a todos os que o haviam acompanhado em seu regresso do Pireu, alguns deles sabidamente escravos. (40.1-2)

Este relato, composto cerca de 70 anos depois dos acontecimentos relatados, indica uma solução tomada pela memória política ateniense diante da dificuldade de não-cidadãos políticos: a moderação de Arquino é sinônimo de manter fechado o corpo cívico, e isto é agir com bom civismo (politeusasthai kalos). A figura de não-cidadão lembrada é a do escravo: haviam escravos no retorno dos democratas, e portanto, estes escravos eram políticos. A solução da memória política de Atenas, tal como produzida na Athenaion Politeia de Aristóteles, é o esquecimento da política dos escravos (e dos metecos, não mencionados) em nome do "bom civismo" - mas isto não impede que a política dos escravos apareça no relato, ainda que por meio de uma referência indireta (o retorno com Trasíbulo). Seria isto indício da vitória da moderação democrática e do esxlusivismo cívico após os anos turbulentos da restauração democrática? É o que afirmam Loraux (2005), Whitehead (1977), Hansen (1993), entre outros. Fica aqui indicado, somente, que a solução do bom civismo como esquecimento encontrou, nos discursos de Lísias, um obstáculo considerável.

\section{c) "Por natureza, nem oligarca, nem democrata": memória e teoria política em Defesa a uma acusação de subverter a democracia (lys.25).}

Datada de entre os anos de 401 e 399, o discurso 25 guarda algumas incertezas quanto à sua inserção jurídica. Não se sabe se foi realmente pronunciado em tribunal, e, se foi, em qual procedimento foi utilizado. O título presente no manuscrito, Defesa de uma acusação de subverter a democracia, indica que se trata de uma ação pública (graphe); entretanto, não há qualquer referência a uma punição a não ser a desonra, 
além de não haver qualquer referência que o orador tenha participado de algum golpe específico. Pelo contrário, o orador defende-se do simples fato de ter permanecido na asty durante o regime dos Trinta, e, como se sabe, a anistia determinava que nenhuma ação poderia ser impetrada contra aqueles que permaneceram na asty, exceto os próprios Trinta.

O tema do discurso é bastante semelhante a outros discursos de Lísias ${ }^{60}$ que são identificados como dokimasiai, ou seja, partes do exame prévio a candidatos apontados para ocupar cargos ou receber privilégios, ainda que este discurso não permita identificar para qual é o cargo em questão ${ }^{61}$. Outra possibilidade é que o discurso não tenha sido pronunciado em tribunal, mas tenha circulado em Atenas como uma espécie de panfleto política em defesa dos que ficaram - para isso contribuem certo aspectos da forma, como o tom didático e as generalizações, e do conteúdo, como os ataques aos abusos do poder democrático e "pragmatismo seco" na explanação da teoria do autointeresse, estes dois últimos aspectos que seriam prejudiciais para a causa em um tribunal popular, mas que caberiam em um texto político ${ }^{62}$.

Qualquer que seja a interpretação correta - discurso para uma dokimasia, panfleto político ou ambos ${ }^{63}$ - subjacente à estas possibilidades está o reconhecimento do procedimento da dokimasia como uma situação espaço-temporal (no tribunal, em menos de um dia) na qual a memória é engajada politicamente. Mas ainda uma dificuldade é posta pelo discurso: trata-se de uma defesa de um cidadão que permaneceu na asty durante o regime dos Trinta. $\mathrm{O}$ argumento típico de defesa deste tipo de acusado, tal como são atacados em outros discursos de Lísias (p.ex., em Contra Evandro), é que a anistia de 403 promoveu o juramento de me mnesikakein, não lembrar os males passados. Como vimos acima, diversos discursos de Lísias (como os discursos $12,13,26$ etc) se colocam contra este juramento: é preciso lembrar do período dos Trinta para que a democracia esteja segura. Mas como defender um cidadão que

${ }^{60} \mathrm{Ou}$ seja, tratam de indivíduos que permaneceram na asty durante o regime dos Trinta: Por Mantitheus (lys.16), Contra Evandro (lys.26) e Contra Eryximachus (frag.9).

${ }^{61}$ Esta é a interpretação de M. Bizos (BIZOS;GERNET, 1954, p.111), S. USHER (EDWARDS;USHER, 1986, p. 269) e S Todd (2000, 260-2).

${ }^{62}$ Este é a interpretação de K. Dover (1968, pp. 188-9); contra Todd (2000, p. 261, n.4).

${ }^{63}$ Porque nada impede que, após a dokimasia, o discurso tenha sido divulgado pelo logógrafo, como era comum e que é a razão para a preservação da maioria dos discursos jurídicos dos oradores áticos (Todd, 1990). 
permaneceu na asty, especialmente no momento (primeiros anos após a restauração) em que a simples permanência já indicava uma filiação à oligarquia? $\mathrm{O}$ esquecimento é a única estratégia possível?

Nas primeiras palavras do discurso, o orador oferece uma solução:

Eu tenho por vocês muita compreensão, senhores do júri, por, ouvindo tais discursos e relembrando o que aconteceu, sentirem cólera igualmente

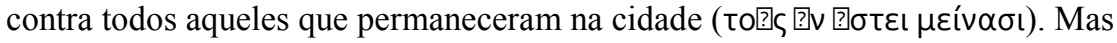
eu me admiro que meus acusadores, negligenciando seus próprios interesses em nome daqueles de outros, e sabendo claramente quais não são criminosos

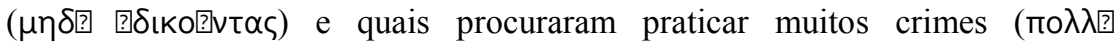

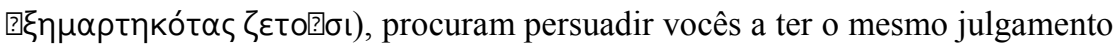
diante de nós todos (25.1).

Diante da lembrança “do que aconteceu”, a cólera do auditório é compreensível, perdoável. A estratégia do discurso será, portanto, enfatizar o esquecimento, relembrar os acordos e juramentos da anistia? Pelo contrário: trata-se de uma qualificação da memória, de uma especificação. A memória democrática, tal como utilizada no discurso de acusação (implícito), considera "aqueles que permaneceram na asty" sob os Trinta como um bloco único, coeso, todos apoiadores da oligarquia e contrários ao retorno dos democratas; é por uma outra memória que se levanta a defesa, por uma memória inacessível diretamente por aqueles que estavam no exílio, posto que busca diferenciar, entre aqueles que permaneceram, os inocentes dos culpados, os que respeitaram a lei (dikountes) e os que não a respeitaram (adikountes). Como os democratas que retornaram do exílio poderiam ter acesso da esta memória (inventada ou não)? Possivelmente por vários meios, mas, certamente, pelo espaço que suporta este discurso: o tribunal aparece como espaço de produção e de crítica da memória. Além do tribunal, a própria circulação do discurso também é um destes lugares de produção e crítica mnemônica, momento alias quando o logógrafo pode enfim aparecer.

A compreensão do tribunal como espaço de produção/crítica da memória, por si, desloca o debate sobre o papel político dos tribunais tal como tem sido realizado: mais do que o poder de julgar, os cidadãos no tribunal teria o poder de fazer memória política, ou melhor, julgariam a partir da memória política que é construída pelos discursos anatagônicos. Esta memória, certamente, opera por diferenciações/identificações: se num primeiro momento ela diferencia o corpo (até 
então) considerado coeso "dos que permaneceram", num segundo momento ela identifica os dois grupos, resultantes da diferenciação, a partir da relação com as leis da polis. Portanto, ao se produzir a memória, aqui, produz-se identidades, ou melhor, contra-identidades, pois é no antagonismo dos discursos que reside a necessidade da exposição das diferenciações. A dokimasia no tribunal se torna, portanto, uma situação (tempo e espaço) na qual as identidades ético-políticas atenienses são suspensas, em que novos conteúdos, novas categorizações são propostas como crítica a outras. Decerto, esta produção ética, por meio das identidades, são conscientes: o atestam os numerosos argumentos de exemplo (aos cidadãos, aos magistrados, a todos os gregos) utilizados em quase todos os discursos judiciários do Corpus. Poderíamos dizer pois que o tribunal, pelo discurso, suporta uma produção ética de identidades políticas pelo uso da memória, que não se limita, certamente, ao campo discursivo: esta ética democrática tal como produzida nestas situações terá influências não somente no caso específico dos litigantes - é em nome da polis que o júri decide, e portanto é a definição de polis e de democracia que estão em questão quando se discute o que é ser democrata ou oligarca em um tribunal.

Mas não é só no campo da memória que age o discurso 25 de Lísias: o orador, antes de argumentar que, tendo permanecido na asty na época dos Trinta, respeitava a lei, oferece uma valiosa discussão sobre os princípios de sua própria argumentação. Diz o orador:

Eu procurarei explicar $(\delta เ \delta \alpha ́ \xi \alpha \iota)$ quais entre os cidadãos são, a meu ver, normalmente desejam a oligarquia e quais a democracia, pois é a partir disso que vocês tomarão sua decisão e que eu farei minha defesa, [pois] mostrando o que eu fiz seja na oligarquia seja na democracia, nada autoriza que eu seja visto como hostil à sua democracia. Primeiramente, é preciso dizer que nenhum ser humano é por natureza oligarca ou democrata; ao contrário, cada ser humano quer qualquer constituição que lhe traga vantagem; depende portanto grandemente de vocês que os defensores da constituição atual se multipliquem. A prova que é exatamente assim, vocês a encontram sem dificuldade nos acontecimentos passados. Considerem, senhores do júri, quão freqüentemente os líderes de ambas constituições mudaram de lado. Frinicos, Pisandro e seus amigos os demagogos não estabeleceram a primeira oligarquia $^{64}$ porque temiam a punição pelos muitos crimes que cometeram

\footnotetext{
${ }^{64}$ Ou regime dos Quatrocentros, instaurado e derrubado em 411.
} 
contra vocês? Muitos dos Quatrocentos ${ }^{65}$, ao contrário, não retornaram do exílio junto daqueles do Pireu? Alguns daqueles que foram exilados pelos Quatrocentos são se tornaram subsequentemente membros dos Trinta? Entre aqueles que registraram seus nomes por Eleusis ${ }^{66}$, existiram alguns que marcharam com vocês e atacaram aqueles que estavam do próprio lado deles. Não é difícil reconhecer, senhores do júri, que não são por constituições (o?

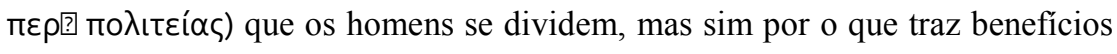

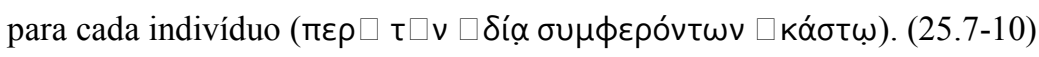

Em momento de extrema honestidade (retórica) argumentativa, ou seja, quando retoricamente expõe os fundamentos de sua própria argumentação, o orador não usa meias palavras para construir uma teoria política própria: o objetivo da ação do "ser humano" é o benefício próprio, e o sujeito é o indivíduo. O ser humano é portanto naturalmente apolítico, e a politeia (democracia ou oligarquia) é um instrumento para a aquisição de vantagem individual ${ }^{67}$ : a politeia é secundária em relação à vantagem individual. Para provar isso, o autor faz a indução pela memória: antigos oligarcas se tornaram democratas, antigos democratas se tornaram democratas - este virar de lado, bem conhecido pelos atenienses, são os casos específicos que permitem a generalização.

Qual é o papel desta teoria política na argumentação? Podem ser percebidas, ao menos três funções. A primeira é a proposição de instrumentos para a avaliação da fidelidade política de cada indivíduo:

Vocês deveriam conduzir uma dokimasia dos cidadãos tendo em vista

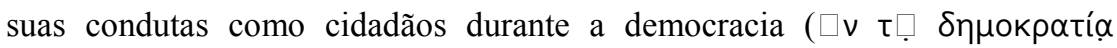

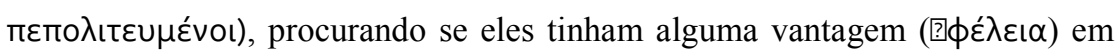
uma mudança de constituição. (25.10).

Assim, a teoria da "escolha política instrumental" deve ser o meio heurístico da dokimasia: o fato de o indivíduo ter alguma vantagem com a mudança de constituição é um indício de que ele não é fiel à atual, portanto não deve passar na dokimasia. Mas

\footnotetext{
${ }^{65}$ Ver nota anterior.

${ }^{66}$ Ou seja, aqueles que, partidários dos Trinta, escolheram migrar, após a restauração democrática de 403, para Eleusis, onde teriam um regime oligárquico.

67 Sem dúvida, M. Finley, na Política no Mundo Antigo (1985), encontraria aqui uma fonte textual autoconsciente para sua crítica à idealização da política presente em estudos como os de C. Meier (1995).
} 
quais são os meios de se descobrir se um cidadão teria ou não vantagem com o fim da democracia ou da oligarquia? Aqui se introduz a segunda função da teoria: afirmar a fidelidade do orador à democracia. Diz o orador sobre si mesmo:

[Na democracia anterior ao golpe dos Trinta] eu servi como trierarca em cinco ocasiões, lutei em batalhas navais, contribui com muitas eisforai durante a guerra e executei as outras liturgias tão bem como qualquer dos outros cidadãos. Mas a razão para eu ter gasto mais do que era determinado

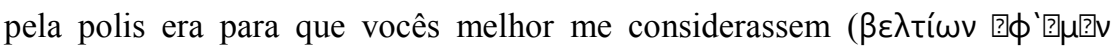

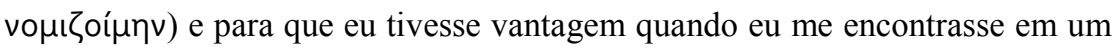
infortúnio - vantagem da qual eu estaria inteiramente privado sob a oligarquia. Os oligarcas não pensaram que aqueles que tivessem sido responsáveis por beneficiar a democracia deveriam receber honras de suas mãos; pelo contrário, eles honraram aqueles que fizeram o mal a vocês, como se eles tomassem isso uma prova de nosso [os que permaneceram] devotamento (25.12-3).

O infortúnio mencionado é, justamente, estar em uma ação judicial injusta, ou seja, promovida por um sicofanta (TODD, 2000, p. 265, n.8). O argumento aqui é a prova da fidelidade por meio de uma noção de reciprocidade: na democracia, ocorre uma troca de pagamentos dos ricos à polis, na forma de impostos especiais, por reputação e consideração dos outros cidadãos, particularmente os membros do júri que estão ouvindo o orador, o que lhe daria vantagem judicial.

Reciprocidade impostos/vantagem judicial, por meio da boa reputação, que só é possível na democracia. Poderíamos supor que a oligarquia colocava impedimentos institucionais à esta reciprocidade: o cancelamento dos impostos especiais cobrados sobre os maios ricos, a transferência da competência judiciárias das mãos dos tribunais democráticos (abertos para todos os cidadãos maiores de 30) para tribunais oligárquicos (como o conselho do Areópago), entre outros. Entretanto, a explicação do orador é mais radical: trata-se da luta entre os oligarcas e o povo, com contornos morais - quem fez o mal ao povo é um bom oligarca, portanto deve ser honrado. A reciprocidade, que honra quem beneficia o povo é, portanto, o fundamento da aliança dos ricos com a democracia: cabe à democracia, na forma do júri popular, manter esta aliança e conseqüentemente a fidelidade de seus membros.

Mas porque então o orador não se exilou com os outros democratas e lutou pelo fim da oligarquia? O discurso é claro na construção de um ethos específico, o 
apragmon, aquele que não se envolve nas questões públicas, ou, na expressão de L. Carter (1986), "the quiet Athenian": o orador ficou na asty pela simples razão de que queria "salvar sua propriedade" e em vista de sua "própria segurança" (25.18). Além disso, o orador não cometeu nenhuma ilegalidade em uma época que cometer um crime era fácil para quem quer que quisesse (25.16). Portanto, diz o orador: "eu considero ter dado à democracia a maior prova de minha fidelidade" (25.17).

Entretanto, essa fidelidade (do orador e dos cidadãos honestos em geral) é posta em risco na democracia por um aspecto do próprio funcionamento institucional do sistema jurídico: o poder da retórica nos julgamento dá origem aos sicofantas, que causam injustiças aos cidadãos honrados (e ricos) por meio de discursos sedutores, lançando mão de argumentos falsos - como é caso, por exemplo, dos acusadores que dizem, injustamente, que todos aqueles que ficaram na asty durante a oligarquia eram criminosos (25.1). Na medida em que os sicofantas manipulam o sistema jurídico democrática para cometer injustiças, eles são os responsáveis por romper as relações de reciprocidade entre os cidadãos ricos e a própria democracia, e aqui surge a terceira função da teoria da "escolha política instrumental": associar os sicofantas às práticas oligarquicas. Ora, se é a reciprocidade impostos/vantagens jurídicas o fundamento da aliança entre os cidadãos (ricos) e o regime democrático, a ação dos sicofantas, ao impedir sua efetivação, pode ser caracterizada como oligárquica:

Vocês devem estar cientes, senhores do júri, que aqueles que estão agora no exílio querem tanto quanto possível que os cidadãos que permaneceram [na asty durante a tirania] sejam difamados e privados de seus direitos cívicos, porque eles esperam que aqueles que foram prejudicados por vocês se tornem aliados de sua causa. Eles gostariam que os sicofantas fossem populares entre vocês e tivessem grande poder na polis, porque eles acreditam que a sua salvação está no comportamento criminoso destes homens. (25.24).

E mais adiante, após discutir o papel dos sicofantas na derrubada da democracia, afirma que

[após a restauração e a anistia de 403] vocês puniram mais prontamente aqueles que eram sicofantas sob a democracia do que aqueles que ocuparam magistraturas sob a oligarquia. Isso é perfeitamente razoável, senhores do júri, pois agora é claro para todos que a democracia foi estabelecida devido àqueles que exerceram o poder injustamente sob a 
oligarquia, e que a oligarquia foi duas vezes estabelecida devido àqueles que eram sicofantas sob a democracia. (25.28)

Assim, é a sicofancia, como prática criminosa, que rompe a reciprocidade entre os cidadãos e a democracia, o que leva à oligarquia. $\mathrm{O}$ argumento de acusação se inverte: na medida em que os cidadãos honestos, que permaneceram na asty durante a oligarquia, aparecem como defensores da democracia (enquanto houver reciprocidade, ou seja, enquanto tiverem vantagens no tribunal diante de acusações promovidas por sicofantas), os cidadãos injustos (sicofantas), mesmo os que foram exilados pelos Trinta e retornaram entre "os do Pireu" (25.29), aparecem como os maiores inimigos da democracia. O que está em jogo é o número dos partidários da democracia, os quais, não sendo por natureza nem democratas nem oligarcas, defendem a politeia que lhes garante vantagens individuais - se na democracia eles podem ser alvo de sicofantas, fatalmente eles se tornarão oligarcas. Mais do que punir os que agiram injustamente na oligarquia, deve-se punir os injustos sob a democracia, pois o comportamento injusto promove a politeia oposta.

Retomando a questão da memória e do esquecimento, pode-se dizer que é parte fundamental da estratégia retórica do discurso 25 a lembrança da época dos Trinta de modo a separar os justos dos injustos, pois os primeiros representam o fundamento da aliança democrática entre cidadãos e democracia, ou mais diretamente, entre os ricos e os pobres (ainda que o discurso tome o cuidado de não se referir a qualquer diferença de renda). E, ao lado do recurso à memória, o discurso faz uso de uma teoria da escolha política fundada na natureza humana, portanto, independente do período e das circunstâncias: todo ser humano busca sua vantagem individual, e a escolha depende não da história da polis ou da relação entre as poleis, mas de como as politeias evitam as injustiças.

O discurso, portanto, lança mão de dois tipos opostos de lugares retóricos: um, histórico, baseado na memória política recente de Atenas; outro, a-histórico, baseado em considerações sobre a natureza humana. No tribunal produz-se, pois, memória e teoria política.

Neste ponto, é justo questionar: seriam restritas aos cidadãos estas produções, de memória e teoria política? Ora, certamente a memória política ateniense e as mais variadas teorias sobre o comportamento políticos dos individuais são produzidos em diversos lugares, por diversos meios, dos quais apenas uma parte nos chegou pela 
tradição; mas, de qualquer modo, temos no discurso 25 do Corpus um momento destas produções, localizado no tribunal (ou, caso seja um panfleto, localizado simbolicamente no tribunal), e que se dá justamente através do discurso. Somente cidadãos poderiam julgar no tribunal, certamente, mas não somente cidadãos poderiam escrever discursos para serem pronunciados em tribunal. De fato, constitui-se em Atenas a concepção de que os tribunais populares eram democráticos na medida em que cumpriam uma das timai do cidadão, como diz Aristóteles: o poder de julgar. Mas vimos que o discurso pode subverter esta restrição, e transformar os tribunais em espaços de produção de memória e teoria política, e na medida em que a escrita de discursos, a logografia, não era restrita a cidadãos, temos portanto um modo de participação política possível, ativa, dos não cidadãos da polis de Atenas, e em particular aos metecos, aos quais a logografia passou a ser associada. 


\section{PARTE III}

\section{Questões}

Somos cinco amigos, certa vez saímos um atrás do outro de uma casa, logo de início saiu o primeiro e se pôs ao lado do portão da rua, depois o segundo, ou melhor: deslizou leve como uma bolinha de mercúrio, pela porta, e se colocou não muito distante do primeiro, depois temos o terceiro, em seguida o quarto, depois o quinto. No fim estávamos todos formando uma fila, em pé. As pessoas voltaram a atenção para nós, apontaram-nos e disseram: "Os cinco acabam de sair daquela casa". Desde então vivemos juntos; seria uma vida pacífica se um sexto não se imiscuísse sempre. Ele não nos faz nada, mas nos aborrece, e isso basta: por que é que ele se intromete à força onde não querem saber dele? Não o conhecemos e não queremos acolhê-lo. Nós cinco também não nos conhecíamos antes e, se quiserem, ainda agora não nos conhecemos um ao outro; mas o que entre nós cinco é possível e tolerado não o é com o sexto. Além do mais, somos cinco e não queremos ser seis. E se é que esse estar junto constante tem algum sentido, para nós cinco não tem, mas agora já estamos reunidos e vamos ficar assim; não queremos, porém, uma nova união justamente com base nas nossas experiências. Mas como é possivel tornar tudo isso claro ao sexto? Longas explicações significariam, em nosso círculo, quase uma acolhida, por isso preferimos não explicar nada e não o acolhemos. Por mais que ele torça os lábios, nós o repelimos com o cotovelo; no entanto, por mais que o afastemos, ele volta sempre.

Franz Kafka, Comunidade. 


\section{A questão política:}

\section{poder, liberdade,}

\section{vida cotidiana}




\section{a) As políticas na Política de Aristóteles}

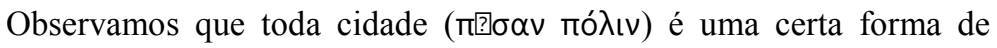
comunidade (Koıvovíav), e que toda comunidade é constituída visando algum bem ([? $\alpha \theta o$ ?]). É que, em todas suas ações, todos os homens visam o que pensam ser o bem. É então manifesto que, na medida em que todas as comunidades visam algum bem, a comunidade mais elevada de todas e que engloba todas as outras visará o maior de todos os bens. Esta comunidade é chamada cidade, aquela que toma a forma de uma comunidade de cidadãos

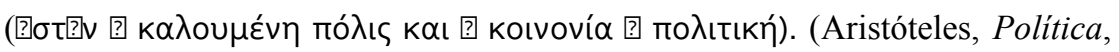
$1252 a)$.

A abertura da Política de Aristóteles, sem dúvida a obra que mais influenciou os estudos históricos sobre a Grécia em geral, traz informações interessantes sobre o que é a política. A Política é uma reflexão sobre a polis. Reflexão que, em Aristóteles, começa pela identificação da polis com uma "comunidade", seguida pela discriminação de dois aspectos da polis: a finalidade e a relação com outras comunidades. A finalidade da polis é atingir o bem maior, justamente porque a polis engloba todas as outras comunidades: a polis se apresenta não apenas como soma de diversas comunidades diferentes, mas como a síntese delas. A "comunidade dos cidadãos" visa um bem como "comunidade", e não como soma de indivíduos: eis o caráter institucional da polis, que se autonomiza de outras dimensões da vida, de outras comunidades. Seria então possível dizer que a política é o que se faz no interior das instituições da polis, ou seja, atividades que visam por meio da comunidade o bem maior? Vejamos antes as comunidades que são absorvidas pela polis.

Quais comunidades? Aristóteles menciona três comunidades criadas de acordo com a natureza. A primeira, macho/fêmea, funda-se na necessidade natural da procriação, como ocorre com animais e plantas. A segunda, senhor/escravo, funda-se no fato natural de que alguns nascem para comandar e outros para obedecer. A terceira, a aldeia, é uma união de famílias e ao mesmo tempo uma família estendida. Cada uma das três foi formada visando um bem específico: homem/mulher, visando a existência; 
senhor/escravo, a segurança; a aldeia, a satisfação da necessidades não-efêmeras. A polis é o resultado da união (lógica, não histórica) destas três comunidades:

A cidade, enfim, é uma comunidade completa, formada a partir de várias aldeias e que, por assim dizer, atinge o máximo de auto-suficiência

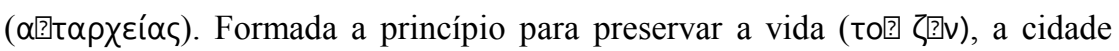

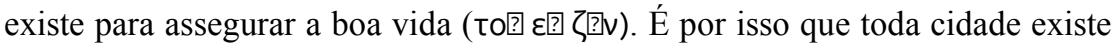
por natureza, se as comunidades primeiras assim o foram. A cidade é o fim

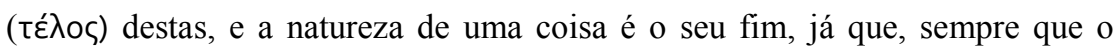
processo de gênese de uma coisa se encontre completo, é a isso que chamamos sua natureza, seja de um homem, de um cavalo, ou de uma casa. Além disso, a causa final, o fim de uma coisa, é o seu melhor bem, e a auto-suficiência é, simultaneamente, um fim e o melhor dos bens. (Aristóteles, Política, 1252b).

O bem maior (fim e natureza) da comunidade de cidadãos é determinado: a autosuficiência, a autarquia. No entanto, o autor introduz uma diferenciação de dois tempos da polis: no primeiro, da formação, a cidade visa a preservação da vida; no segundo, da existência, a cidade visa a "boa vida". Duas tríades são estabelecidas: finalidade/formação/existência, autarquia/vida/boa vida. Seria a política a atividade que visa a vida, a boa vida, ou a autarquia, ou todas juntas? E mais: estaria limitada esta atividade às instituições da comunidade dos cidadãos, ou poderia ser exercida em outras modalidades, como a vida cotidiana, a vida privada, e por outros sujeitos, como as mulheres, os escravos, os metecos? Poderíamos chamar de política a atividade de um meteco que, pelo comércio, garante a autarquia da polis, ou de uma mulher que, criando um filho, preserva a vida na polis, ou de um escravo que, lutando pela democracia contra a oligarquia, visa a restauração da boa vida na polis? Vejamos ainda a caracterização do ser humano no contexto da polis:

Estas considerações deixam claro que a cidade é uma daquelas coisas que existem por natureza e que o homem é, por natureza, um ser vivo político ( $\pi \circ \lambda \iota \tau \iota \kappa \square \nu \zeta \square$ ov). Aquele que, por natureza e não por acaso, não tiver cidade, será um ser decaído ou sobre-humano, tal como o homem condenado por Homero como "sem família, nem lei, nem lar"; porque aquele que é assim por natureza está, além do mais, sedento de ir para a guerra, e é comparável à peça isolada de um jogo. A razão pela qual o homem, mais do que uma abelha ou um animal gregário, é um ser vivo político em sentido pleno, é óbvia. A natureza, conforme dizemos, não faz nada ao acaso, e só o homem, de entre

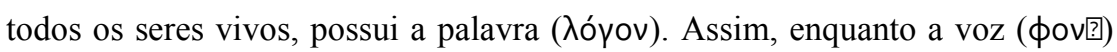


indica prazer ou sofrimento, e nesse sentido é também atributo de outros animais (cuja natureza também atinge sensações de dor e de prazer e é capaz de as indicar) a palavra, por outro lado, serve para tornar claro o útil e o prejudicial e, por conseguinte, o justo e o injusto. (Aristóteles, Política, 1253a).

O homem é um ser vivo político pois é dotado de palavra, logos, e assim se opõe aos animais e aos deuses, aos sedentos por guerra e aos isolados "sem família, nem lei, nem lar" homéricos, inferiores ou superiores aos homens, ou como o autor vai dizer na seqüência, "um bicho ou um deus". A palavra é oposta à voz: se a última exprime somente a dor e o prazer, a primeira consegue exprimir o útil/justo e $\mathrm{o}$ prejudicial/injusto. A capacidade política do homem é portanto uma capacidade discursiva, que visa a expressão da utilidade e da justiça. A política seria, portanto, esta expressão? Todo aquele que, por não ser nem inferior nem superior aos homens, consegue expressar a utilidade e a justiça, pratica portanto a política? Neste sentido, a guerra, o comércio ou a criação dos filhos não seriam atividades políticas; mas nem por isso a palavra da utilidade e da justiça estaria confinada às instituições da polis, e portanto aos cidadãos. Ou estariam? Quando metecos, escravos ou mulheres participassem de uma discussão sobre a utilidade e a justiça de quaisquer coisas, e mesmo fora dos lugares "políticos" como a Assembléia, o Conselho ou os tribunais; esta discussão não seria política, por seus sujeitos não serem cidadãos? Mas ainda há mais elemento acrescentado na continuação do texto.

É evidente que a cidade é, por natureza, anterior ao indivíduo

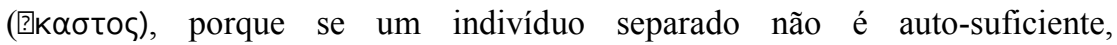
permanecerá em relação à cidade como as partes em relação ao todo. Quem for

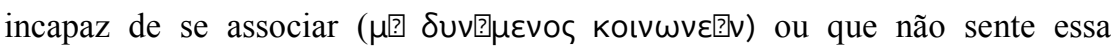
necessidade por causa da sua auto-suficiência, não faz parte de qualquer cidade, e será um bicho ou um deus (? Onpíov ? Ocós). (Aristóteles, Política, $1253 b)$.

Neste trecho, à capacidade de fala, se acrescenta uma incapacidade de suficiência do ser humano individual. Se antes era a presença da fala, ou seja, uma característica positiva, que fazia do ser humano um ser vivo político, agora é a ausência da autarquia, negativa, que obriga o homem a se tornar político. A marca da politização do homem, neste trecho, é a entrada e o pertencimento à comunidade, que faz com que 
o ser humano passe do negativo para o positivo: a insuficiência individual leva o homem, dotado de potência associativa, à constituição da auto-suficiência da polis. $\mathrm{O}$ devir-político do homem aqui é definido, portanto, da vida em comunidade, para o qual o homem tem tanto capacidade quanto necessidade. Seria a política, portanto, a própria vida comunitária? Algo como uma arte do viver-com, uma habilidade dos homens para entrar em relação com outros homens capazes para e obrigados a viver deste modo?

O que é a política nestes trechos inicias da Política de Aristóteles? Nesta leitura livre, quatro definições aparecem: a política é (a) a atividade própria à comunidade dos cidadãos; (b) a atividade que visa a autarquia, a vida e a boa vida na/da polis; (c) a expressão discursiva da utilidade e da justiça; (d) a vida em comunidade. Estas definições se conjugam, quando se lê tais definições como uma acumulação conceitual: política é o que a comunidade de cidadãos faz visando a autarquia/vida/boa vida por meio da expressão discursiva da utilidade e da justiça e da vida comunitária. No entanto, o encadeamento do texto não traz a idéia, a meu ver, de uma acumulação: o discurso é entrecortado de considerações metodológicas e idas e vindas lógicas da polis para a família, desta para a polis, desta para o homem. Se a idéia de uma acumulação conceitual for deixada de lado, aparecem oposições entre as definições, e algumas categorias que seriam políticas de acordo com uma definição, não o seriam por outra: o comércio de metecos, por exemplo, pode visar a autarquia da polis, mas ultrapassa a comunidade de cidadãos e ao mesmo tempo que não é uma "expressão discursiva"; as interações entre mulheres em eventos fúnebres faz parte da vida em comunidade, mas não visa necessariamente a autarquia; cidadãos em batalha agem como uma comunidade de cidadãos, mas não o fazer por meio da expressão discursiva; etc. Como resolver estes impasses?

Uma outra questão parece mais apropriada: é preciso resolvê-los? Ora, as muitas definições de política, na primeira sessão da Política, podem apontar para a existência de um debate, realizado por diversos suportes, sobre o que era ou deveria ser a política, quais seus conteúdos, seus métodos, seus sujeitos. As contradições, ao invés de dilemas, se tornam pontos de partida metodológicos: a quais lógicas sociais correspondem cada definição (se uma correlação for possível)? Não é o caso, aqui, de realizar um estudo sobre a inserção social das definições aristotélicas de política, mas está à mão ao menos um dado precioso: se entendermos política num sentido bastante amplo, como o proposto por Francis Wolff em seu clássico comentário da Politica de Aristóteles, 
segundo o qual "a política é a prática da polis que se tornou consciente de si própria, ou, inversamente, a investigação sistemática aplicada à polis" (1999, p. 7), o que dizer da própria Política de Aristóteles? Esta obra, certamente, é política, na medida em que é uma "investigação sistemática aplicada à polis", ou, seguindo Aristóteles, uma expressão discursiva sobre o que é justo e injusto, útil ou prejudicial. Como se sabe, Aristóteles viveu em Atenas durante cerca de 40 anos, e tendo nascido em Estagira, sua posição institucional era a de meteco ateniense. Por que restringir a política ao cidadãos, mesmo quando Aristóteles o faz, se o próprio fazer da Política indica outras direções?

Em diversos momentos a política fez sua aparição textual nesta dissertação - em nenhum deles ela foi definida. Mas como fazê-lo? Na própria tentativa de definir o que é a política já está uma definição: a política como objeto do conhecimento, inteligível, definível, limitável, ou seja, a política é um objeto de um pensamento que consegue marcar suas fronteiras entre o que é e o que não é política, e mais do que isso, consegue traduzir em conceitos a finalidade da política. Seria a política definível?

A seguir, a política será não definida, mas problematizada, a partir de duas vias, de duas discussões: primeiro, das relações entre política e poder, e em seguida, das relações entre sobre política e liberdade. Busca-se, com isso, promover uma ampliação conceitual da política para além dos limites institucionais do Estado, na direção das relações de poder e das práticas de liberdade, analisando como que estas discussões influenciaram os estudos sobre a democracia ateniense.

A proposta é pensar a política como relacionada a uma prática da liberdade, mas cuja análise não despreze o Estado e as relações de poder. Mas a partir de qual lugar, do ponto de vista do pensamento, seria possível analisar simultaneamente as práticas de liberdade, as relações de poder e as instituições estatais? Será explorado aqui o caminho da "História do Cotidiano" (item c), campo histórico inspirado em particular nos estudos de Henri Lefebvre e Agnes Heller. Estes autores apresentam duas visões do cotidiano que são geralmente apresentadas como incompatíveis: o primeiro pensa o cotidiano como uma realidade social cuja forma e conteúdo variam historicamente nem todas as sociedades teriam uma "vida cotidiana", de modo que é necessária uma problematização dos conceitos e noções que cada sociedade utiliza para determinar o que seria próximo da "moderna" vida cotidiana; a segunda pensa o cotidiano como uma dimensão ontológica da vida social, ligada à reprodução particular das determinações sociais mais gerais - o cotidiano existiria em todas as sociedades, na medida em que 
elas se reproduzem como tais. Um dos objetivos deste capítulo é dialetizar estas duas noções de cotidiano, além de expor as possibilidades desta dialética quando posta diante da questão da política.

\section{b) Do Estado às relações de poder}

A noção de política é geralmente associada à idéia de poder, e em particular o poder do Estado. Mas o que esta associação significa exatamente? Pode-se dizer, de um modo geral, que três respostas têm orientado os estudos da política: a política é aquilo que o Estado faz; a política é o conjunto das ações orientadas para o Estado; a política é o conjunto das relações de poder que ultrapassam o Estado.

A primeira, que poderíamos chamar de institucionalista, oriunda principalmente dos estudos de direito constitucional, considera que uma boa descrição do funcionamento institucional dos Estados dá conta da política de uma dada sociedade: com tons positivistas, a via institucionalista se preocupa em determinar se é possível, com base na documentação, afirmar se esta ou aquela instituição tinha ou não determinadas funções.

A segunda, mais sociológica, derivada particularmente das análises de Max Weber, entende a política como prática que ultrapassa os limites institucionais, mas de qualquer modo sempre visa o Estado. Nas palavras de Weber, a "associação política propriamente dita" é o Estado, enquanto que a "ação politicamente orientada" é toda aquela que pode "produzir, impedir ou fomentar a manutenção ou a transformação ou a subversão" das relações de dominação dentro de um Estado (WEBER, 1999a, p. 34).

A terceira, que pode ser chamada de genealógica, procura ultrapassar radicalmente as fronteiras do Estado e perceber as relações de poder fora dele e que não o visam, ao menos diretamente. É o caso da inversão provocada por Michel Foucault na sua genealogia do poder, que percebe o poder sendo exercido em múltiplos lugares e tendo um caráter produtivo de discursos, verdades, práticas, subjetividades - a leitura foucaultiana do poder o percebe como algo que não se limita à coerção e ao Estado, mas que atravessa as instituições e práticas sociais as constituindo.

Estas três vias de análise das relações entre política e poder (institucional, sociológica e genealógica) influenciaram direta ou indiretamente os estudos sobre a 
democracia ateniense. Destacaremos aqui algumas abordagens que demonstram estas influências: para a via institucional, o livro de M. Hansen The Athenian democracy in the Age of Demosthenes; para a via sociológica, o livro de M. Finley A politica no mundo antigo; para a via genealógica, os textos de J. Ober presentes em The Athenian Revolution e o livro de M. de Andrade $A$ vida comum.

\section{O papel das instituições segundo M. Hansen}

Mogens H. Hansen, certamente, tem sido um dos historiadores mais influentes nas últimas décadas a respeito do estudo da democracia ateniense: responsável pela realização e coordenação de estudos de vulto, o diretor do Copenhagen Polis Centre também se notabilizou pela abordagem institucionalista da história da democracia ateniense. Um dos exemplos mais eloqüentes é o seu estudo sobre a democracia ateniense na época de Demóstenes (1993), cujo núcleo é a descrição das funções e dos funcionamentos das instituições políticas da democracia, como a Assembléia, o Conselho, o Tribunal, as Magistraturas etc. Mas o que é uma instituição para Hansen, ou qual é a relação entre as instituições, a política e a sociedade? Em primeiro lugar, não havia separação entre política e instituições:

Para os atenienses, tudo o que concernia à polis era "político": eles eram perfeitamente capazes de distinguir entre a preparação, a tomada de decisão e a execução, mas eles não faziam a distinção entre o político e o administrativo e a seus olhos, ser um magistrado ou um juiz era uma atividade tão política quanto tomar parte às reuniões na Assembléia. Quando Aristóteles define a liberdade política que reina em um Estado pelo fato de "ser governado e governante", ele pensa na rotação dos magistrados e não a qualquer rotação no funcionamento da Assembléia. [...] Uma descrição da democracia ateniense como sistema político deve abarcar todas as instituições políticas da cidade: a Assembléia, os nomothetas, o Tribunal do Povo, os colégios de magistrados, o Conselho dos Quinhentos (o mais importante dos colégios), o Areópago e ho boulomenos, todo cidadão que o deseje (HANSEN, 1993, pp. 98-9).

Desta indissociação entre política e instituições, derivada da concepção dos próprios atenienses, Hansen traduz a politeia como sistema político, ou seja, como arranjo institucional que abrange tanto os aspectos (que hoje seriam denominados 
como) administrativos e políticos do Estado: citando Aristóteles como porta-voz dos "atenienses", Hansen faz com que uma concepção política se torne um roteiro historiográfico - a história da democracia ateniense se faz pela descrição e análise das instituições da polis. Decerto, Hansen está consciente de suas escolhas metodológicas, como prova uma espécie de antecipação a críticas feita nas últimas páginas de seu livro:

Faz-se freqüentemente, a título justo, a observação de que a democracia não era somente uma constituição e uma série de instituições, mas também um modo de vida. $\mathrm{Na}$ mentalidade grega, nenhum regime poderia funcionar corretamente se o estado de espírito e o modo de vida dos cidadãos não se adaptassem a ele; não havia democracia sem o homo democraticus (demokratikos aner) e o "democratic way of life" (demotikon ethos). Certamente; mas por retornar ao pensamento grego, era claro que eram as instituições políticas que modelavam o homem e a vida democrática, não o inverso: as instituições da polis educavam os cidadãos e constituiam para seu modo de vida uma espécie de molde; para se ter a vida mais feliz, era preciso ter as melhores instituições e um sistema de educação que lhe fosse conforme [são referidas passagens de Platão, Aristóteles e Simonides] (HANSEN, 1993, p. 364).

Assim, novamente, é por meio do "pensamento grego" que Hansen fundamenta seu método: a descrição e análise das instituições demonstram a centralidade que os próprios gregos davam para o tema. Assim, a descrição e a análise das instituições democráticas atenienses são uma via privilegiada para se acessar o modo de vida, o ethos dos cidadãos atenienses: se as instituições modelam a sociedade, uma boa descrição das instituições modeladoras dá conta de uma descrição da sociedade modelada - a história da sociedade ateniense clássica é, pois, a história de suas instituições.

Ora, diversas críticas podem ser feitas (e foram) a este princípio metodológico. Uma das mais incisivas é a resenha de J. Ober, The Nature of Athenian Democracy (1996, pp. 107-22) sobre um livro de Hansen dedicado especificamente à assembléia democrática ateniense (HANSEN, 1987). Segundo J. Ober, o método institucionalista adotado pelo historiador dinamarquês, pelo qual as instituições e seus princípios (moderação, separação de poderes, soberania da lei etc) modelam as práticas sociais, resulta em uma visão teleológica da história: 
Os princípios abstratos nos quais as constituições são construídas são, para Hansen, em algum sentido exteriores à matriz social e ao setor das práticas políticas. Princípios são aparentemente a força que causa mudança. Devido à estes princípios guiadores, pode-se afirmar, o desenvolvimento constitucional era linear, teleológico e "conservador" [whiggish] no que era procurado como um fim definido, e este fim era bom. Assim, a evolução constitucional do quarto século procedeu inexoravelmente no sentido da criação de uma democracia moderada, legalista e ordeira (OBER, 1996, p. 112).

Assim, os princípios são os verdadeiros sujeitos das mudanças institucionais, às quais a sociedade deve se modelar - em outras palavras, os princípios ganham vida, enquanto as relações sociais são reificadas. Uma das conseqüências deste movimento é que determinadas questões sócio-políticas são subordinadas a preocupações procedurais:

[Hansen] afirma que a introdução do pagamento [pelo comparecimento na Assembléia] e subseqüente crescimento na taxa deste pagamento foram motivados pelos requisitos constitucionais para se assegurar um quorum. Pode-se argumentar antes que a reforma foi motivada pela determinação das classes baixas atenienses para assegurar que a Assembléia não fosse dominada pelas classes altas - que eram vista (corretamente ou não) como prováveis apoiadores da oligarquia. (OBER, 1996, 113).

Segundo o autor, portanto, os conflitos sociais desaparecem na abordagem de Hansen em nome da estabilidade constitucional: é contra uma imagem pacificada da democracia ateniense que J. Ober lança mão de leituras foucaultianas da discursividade do poder, conforme será analisado mais adiante.

\section{Estado e ação política segundo M. Finley}

O livro de M. Finley, A política no mundo antigo, se levanta contra as visões neutralizantes da política, que ora tendem a ver os conflitos políticos como reflexos dos "vícios privados" dos sujeitos, como nas análises moralizantes de historiadores e juristas, ora tendem a minimizar os conflitos em nome de identidades, permanências e 
imobilidades tradicionais, como nos estudos antropológicos ${ }^{68}$. Finley adota três postulados para análise da política e do Estado no "mundo antigo": (1) o Estado é uma arena de conflitos de classes; (2) o poder do Estado sobrepuja os outros poderes sociais; e (3) a escolha de governantes e os modos de governo dependem da estrutura da sociedade examinada (no caso, influem a escravidão, a restrição no acesso à cidadania e a exclusão das mulheres). Por meio destes três postulados, M. Finley constrói aquilo que seria uma história social da política, analisando temas como as relações entre ricos e pobres, a participação política, as relações de patronato, a aceitação popular da ideologia da elite etc. A certa altura, o autor afirma que

a investigação sobre o Estado e o governo antigos precisam descer da estratosfera, dos conceitos rarefeitos, mediante um exame não só da ideologia, do orgulho "nacional" e patriotismo, de Der Staat, das glórias e misérias da guerra, mas também de relações materiais entre os cidadãos ou classes de cidadãos, tanto quanto as mais comumentes observadas entre o Estado e os cidadãos (FINLEY, 1985, p. 64).

Assim, contra a tradicional história política e militar das cidades-estados, Finley insere a problemática das relações materiais entre Estado e cidadãos. Mas, dentro desta visão sociológica, o que é a política para Finley? Seguindo M. Weber, Finley entende a política como a ação do ou visando o Estado: distinguindo o Estado de quaisquer outros agrupamentos "sociais, econômicos, educacionais ou o que for", o autor afirma que não se interessa "por usos metafóricos tais como "política acadêmica" (FINLEY, 1985, p. 68). Assim, a "academia" não conteria a política, monopólio do Estado em suas relações com os cidadãos.

É justamente neste ponto que se encontra uma importante limitação na abordagem finleyniana: a cidade é vista como uma comunidade de cidadãos, de modo que os não-cidadãos não contem para a história social da política antiga. Finley, portanto, identifica a "sociedade" a "cidadãos", relegando os não-cidadãos ao plano de fundo da história. Esta exclusão historiográfica acaba gerando contradições na própria

68 Uma crítica semelhante à de Finley à neutralidade antropológica, especificamente de tendência francesa, está em dois artigos de Nicole Loraux: Repolitiser la cité (1986) e Comment repolitiser la cité (1984). Para uma resposta às críticas de Finley, cf. TERRAY (1989). 
argumentação do autor, quando é abordado o tema da estabilidade política e social de Atenas e Roma.

Para o autor, em ambas cidades "os corpos de cidadãos eram minorias que exploravam grande quantidade de homens, livres e escravos" (FINLEY, 1985, p. 104). No caso de Roma, a explicação se baseia principalmente nos valores hierárquicos da educação, na oralidade da cultura antiga e no controle político-institucional e o poder religioso da aristocracia sobre as instituições da plebe. No entanto, Atenas é sempre exceção: quanto à educação, a possibilidade da participação política para todos os cidadãos servia como formação política; quanto à oralidade, especificamente no poder daqueles que detém a escrita no campo jurídico, em Atenas não houve uma classe de juristas profissionais oriundos da elite (como em Roma); quanto ao controle políticoinstitucional e religioso da aristocracia, abundam exemplos contrários no caso ateniense. Como se explica então a estabilidade de Atenas? Finley dá algumas indicações: o fortalecimento do demos diante da dissolução do clientelismo dos aristocratas, a proteção econômica aos camponeses, a "responsabilidade cívica". Isso explicaria, segundo Finley, a estabilidade interna do corpo cívico. Mas e quanto à "grande quantidade de homens, livres e escravos" que são explorados pelos cidadãos, porque não se rebelam, por que reproduzem a estabilidade? $\mathrm{O}$ autor nada diz sobre quais eram suas ideologias políticas, suas relações materiais com os cidadãos e com o Estado, e a estabilidade ateniense, diante da restrição da política às relações entre Estado e cidadãos, continua paradoxal.

\section{Discurso, poder e política segundo J. Ober e M. de Andrade}

A via que está sendo chamada aqui de genealógica se refere aos estudos que analisam a relação entre política e poder para além do Estado, ou seja, as relações de poder não são produzidas no Estado e dali parte para o controle da sociedade, mas, pelo contrário, são produzidas na sociedade e atravessam as instituições, inclusive o Estado. Exemplos dessa abordagem são as relações de poder estabelecidas entre um entrevistador e um entrevistado, como nota Michel Foucault (2004) durante uma entrevista, ou as relações de poder não-coercitivas que impedem o surgimento de um poder coercitivo, o Estado, como argumenta Pierre Clastres (1990, p. 17). Trata-se, portanto, de relações de poder que estão fora do Estado ou contra o Estado. 
São poucos os estudos da democracia ateniense que explicitam a influência da via genealógica do poder; destes, destacaremos aqui as análises de J. Ober sobre a discursividade da democracia ateniense e de M. de Andrade sobre o caráter ideológico do discurso cívico ateniense e as possibilidades de uma política dos não-cidadãos.

J. Ober assume a perspectiva genealógica da análise do poder abertamente em dois textos, ambos voltados para a questão do discurso democrático. O primeiro, intitulado Power and Oratory in Democratic Athens (OBER, 1996, pp. 86-106), é um estudo de caso de um discurso de Demóstenes (Contra Mídias), no qual o autor discute as relações entre massa e elite do ponto de vista do controle discursivo da democracia por meio da oratória. Interessa-nos aqui, especificamente, a exposição dos pressupostos metodológicos da análise do poder feita pelo autor: rejeitando o "paradigma coercitivo", pelo qual o poder é visto como centrado no Estado, que define o que é legitimo e ilegítimo, e baseado no uso da força repressiva, J. Ober defende, fortemente baseado em Michel Foucault, o "paradigma discursivo", pelo qual

o poder não está centralizado em lugar algum, e não é nem legítimo nem ilegítimo. Assim soberania não é um tema, e um estudo das instituições jurídicas formais isoladas não revelará os fundamentais mecanismos do poder. Antes de ver o poder como repressivo, o paradigma discursivo vê o poder como produtivo: ele emerge por meio da produção social de conhecimentos visando o que é verdade e quais condutas são corretas, próprias, e mesmo concebíveis. [...] A violência coercitiva é ela mesma parte de um discurso: o regime de saber prescreverá sob quais condições uma categoria de pessoas pode ou não perpetrar violência sobre outra e o que constitui violência [...]. O regime de saber/verdade/poder é pois mantido através do discurso. Uma questão chave que se coloca para o estudioso do poder pensando dentro do paradigma discursivo é como, e por quem, saberes sociais são produzidos e reproduzidos - ou desafiados e derrubados (OBER, 1996, pp. 89-90).

A partir do "paradigma discursivo", J. Ober se volta para o problema do regime de verdade específico da democracia ateniense, e suas relações com o sistema de valores das elites. No texto em questão, o autor discute este problema especificamente no caso do Contra Mídias de Demóstenes; porém, em outro texto presente no mesmo livro, a questão é endereçada ao funcionamento geral da democracia ateniense. Em Public Speech and the Power of the People in Democratic Athens (1996, pp. 18-31), J. Ober aborda a questão de se a democracia ateniense era uma democracia genuína ou se 
tratava de uma oligarquia disfarçada. $\mathrm{O}$ autor lista 5 formas de domínio de uma elite sobre uma democracia em geral:

1. A elite domina a assembléia e os tribunais numericamente.

2. A elite domina o voto aberto por meio do clientelismo.

3. A elite controla a agenda política.

4. As instituições controladas pela massa são submetidas às decisões de uma burocracia dominada pela elite.

5. O discurso e os valores da elite são hegemônicos, restringindo as práticas democráticas.

No caso da democracia ateniense clássica, o autor refuta as 5 formas, dizendo que (1) a massa dominava numericamente a assembléia e os tribunais, incentivada pelo pagamento pela participação; (2) as relações de clientelismo, regra para Roma, não existiam em Atenas; (3) a agenda política era determinada pelo Conselho, órgão composto por membros escolhidos em sorteio e que não poderiam ocupar o cargo por mais de dois anos consecutivos, impedindo assim tanto a seleção elitista quanto uma identidade entre as composições de conselheiros; (4) os magistrados, ainda que fossem na maioria eleitos e não tirados em sorteio, deviam prestar contas para audiências populares antes e depois do exercício da magistratura; e (5) a ideologia do demos ateniense era altamente democrática, como se observa em alguns princípios: primeiro, não era vista como necessária uma educação especial para o cidadãos, pois a própria Assembléia o fazia; a cultura da autoctonia ateniense fazia como que todos os atenienses compartilhassem de uma "nobreza" de nascimento; a ideologia democrática não era contrária à desigualdade econômica, mas incentivava a redistribuição voluntária da riqueza da elite (por meio da competição entre quem contribuía mais ao povo) e no reforço da igualdade política; os cidadãos eram livres para criticar a democracia, contanto que o fizessem fora do espaço do discurso público, ou seja, podia-se criticar a democracia somente na escrita e em conversas privadas.

Com essa argumentação, J. Ober procura provar sua premissa, exposta no início do texto, segundo a qual

a democracia de Atenas, como todas as democracias, era ameaçada (de fato ou potencialmente) pelas tentativas de poderosas elites em dominar o setor público. No entanto, o exercício do poder coletivo pelo demos ateniense evitava a dominação política da elite - e isso era intencional. Assim, na Atenas Clássica, o "poder do povo" não era uma capa para o mando da elite. Essa 
vitoriosa defesa da democracia contra as forças do elitismo era predicada pela dominação do aparato decisório essencial para a tomada de decisões pela massa dos cidadãos, ou seja, pela "hegemonia ideológica" do demos (OBER, 1996, p. 19).

Assim, essa hegemonia ideológica do demos sobre a elite era o que fazia da democracia ateniense uma democracia de fato, caracterizada pelo controle popular do discurso público. Unindo estas conclusões às premissas do paradigma discursivo, podese dizer que, para o autor, a democracia se assentava justamente no controle popular da produção do regime de verdade (o saber-poder) democrático, ao qual a elite tinha de se submeter.

A abordagem do poder discursivo da democracia, segundo J. Ober, certamente contribui em grande medida para uma visão mais complexa das relações de poder presentes na prática política ateniense. No entanto, o autor reproduz uma limitação que marca a historiografia da polis, e esta limitação tem reflexos sobre sua própria interpretação. J. Ober limita a ideologia democrática aos cidadãos atenienses, que podem participar ativamente nos espaços civicamente determinados como "políticos": a Assembléia, o Conselho, os Tribunais. Nestes espaços, a luta entre as massas dos cidadãos (pobres) e a elite de cidadãos (ricos) se realiza, com a vitória dos primeiros. Mas, pode-se perguntar, e os não-cidadãos? Se limitaria a ideologia democrática aos cidadãos, ou ela estaria espalhada socialmente, em espaços outros que as instituições restritivas?

A limitação da questão ao corpo cívico, mesmo que cindido em ricos e pobres, coloca problemas, assim como ocorreu com Finley, para a explicação da estabilidade da democracia ateniense. J. Ober vê a democracia a partir de um modelo liberal: faz parte da ideologia democrática o respeito à desigualdade econômica, pois esta é atenuada pela igualdade política - ambas restritas ao corpo cívico.

Em seu livro $A$ vida comum, M. de Andrade abordou o tema dos modos pelos quais a apropriação do espaço urbano pelos habitantes, em particular as mulheres, eram representadas em discursos produzidos por cidadãos em suportes variados, tais como a cerâmica, o teatro, o discurso epidítico, a teoria política etc. Nesta abordagem, conforme dito anteriormente (capítulo 1, item c), a autora constroi uma categoria de vida cotidiana a partir do termo grego kath'oikian, vida comum ou doméstica, na qual as interações 
sociais entre habitantes não se limitariam aos padrões determinados em função dos privilégios dos cidadãos: mais do que circular entre os espaços abstratos da polis e do oikos, os habitantes se apropriariam do espaço de maneiras variadas - o discurso cívico, portanto, se torna uma ideologia, e o discurso sobre o cotidiano é chamado de uma politização do cotidiano.

A questão do cotidiano será retomada mais adiante (neste mesmo capítulo, item c); por ora, cabe refletir sobre o termo politização. Em A vida comum, M. de Andrade não realiza uma conceituação direta da política, que aparece ora com adjetivo do discurso dos cidadãos (o "discurso político grego"), ora como uma prática discursiva dos cidadãos sobre a vida cotidiana (a "politização do cotidiano"). Será num texto posterior (ANDRADE, 2008) que a autora se defrontará mais detidamente com a questão. Em uma leitura bastante influenciada pelas discussões do poder e da política de Michel Foucault e Pierre Clastres, a autora, partindo da idéia de que a política é a dimensão na qual uma sociedade coloca a questão do poder (Clastres) e do caráter discursivo e capilar do poder (Foucault), pensa a possibilidade política dos nãocidadãos:

Precisamos escutar o que se diz e perscrutar o que se faz da polis na Atenas Clássica quando o que está em questão é o poder, e a questão do poder coloca a politeía diante da vida comum dos habitantes, diante de negociações e conflitos políticos em torno dos espaços de exposição, publicização, palavra, guerra, economia, religião. Esta mudança de foco determina a superação de um modelo clássico de teoria política, possibilitando investigar o conteúdo político da participação e mobilização de outros atores que não os cidadãos, sem o privilégio do espaço institucional estratégico da "cidade-estado" (ANDRADE, 2008, p. 12).

O deslocamento da política do Estado para "questão do poder" revelaria, portanto, a prática política dos não-cidadãos para além da restrição institucional, política, portanto, de mulheres, estrangeiros, escravos e crianças. Quais seriam os modos desta política? Retomando a definição de Pierre Clastres, diz a autora:

Lembremos do fundamental, a dimensão política como aquela em que a sociedade coloca a questão do poder. Isto significa, aquela que ela prepara não apenas para dizer algo ou exercer o poder, mas para recebê-lo, redirecionálo, fazê-lo circular e produzir. Não se remete somente ao âmbito da palavra, 
mas à dimensão prática da vida social, no que ela implica em termos das "artes de fazer", mas também no que ela tem de discursivo. Assim, não é o poder que está em toda parte; podemos até dizer o contrário, ou seja, que o poder não está em parte alguma onde ele não seja colocado pela política. E isto tem efeitos bem concretos.

No mundo contemporâneo, o lugar do poder é aquele onde é colocado pela política: nas instituições, na incidência das instituições sobre os indivíduos - igreja e fiéis, estado e povo, família e sujeito, corpo e gênero, ciência e senso comum, eu e eu mesmo, enfim. [...] Mas o fato é que, também nesse indefinido "mundo contemporâneo", tornam-se visíveis e pensáveis por esforços múltiplos de investigação outros espaços não institucionalizáveis para o problema político da vida social, da koinonia (ANDRADE, 2008, pp. 14-15).

Entre discurso e ação, entre os lugares de poder instituídos e não institucionalizáveis (as heterotopias), a política assume a forma de uma dimensão, produzida socialmente, que coloca e desloca o poder como questão. Podemos supor que a heterotopia, presente no mundo contemporâneo, está presente em toda a sociedade que apresente o poder como questão, ou seja, sociedade "políticas": no caso ateniense, conforme foi discutido no capítulo 5 , a criação de heterotopias poderia se dar pela reconfiguração de espaços e de identidades contra as demarcações de funções presentes na ideologia cívica de identificação da polis com a comunidade de cidadãos.

No entanto, neste fluxo contínuo de poderes e contra-poderes, a autora introduz um atributo a mais da política, que ultrapassa a questão do poder: a política que se volta à questão da vida social, da koinonia. Quais são os conteúdos desta dimensão política em que não estão (somente) em questão as relações de poder, mas a própria vida coletiva? Neste ponto, o estudo da política como relações de poder, no e além do Estado, indicam um caminho que aponta para uma problemática mais ampla da política, que passa pela questão do poder mas não se restringe à ela, uma problemática que, incorporando as realizações da abordagem anterior (a indissociação entre teoria e prática, discurso e ação, lugar instituído e heterotopia, sujeito e objeto), coloca em questão o próprio sentido do poder: trata-se da abordagem que pensa a política como prática da liberdade ${ }^{69}$.

${ }^{69}$ M. de Andrade, em texto anterior (O Tempo e os Outros, de 2004), parte de uma noção de política como arte do convívio, ou ainda, como colocação do viver-com como questão, para pensar as implicações ético-políticas de uma escrita heterotópica da história. 


\title{
c) Liberdade e cotidiano
}

\author{
O anfiteatro da liberdade em Hannah Arendt
}

Uma das principais pensadoras do século XX, Hannah Arendt tornou-se bastante conhecida por conta de suas reflexões no campo da filosofia política. De sua vasta obra, será retomado aqui um pequeno texto intitulado $O$ que é liberdade, no qual a autora analisa as relações contraditórias entre "filosofia" e "política": a filosofia nos seus primórdios surgiu, segundo a autora, contra a política. Se por um lado a filosofia é marcada pela contemplação, por outro a política é marcada pela ação; se a filosofia pertence ao nível do pensamento, a política pertence ao mundo das palavras e feitos públicos. Onde se situa a liberdade nesta oposição? Segundo Hannah Arendt, se nos primeiros tempos da filosofia, em Parmênides e Platão, a liberdade pertencia à política e portanto não era um tema do pensamento, a filosofia do fim da Antiguidade operará uma transformação no significado da liberdade, transformando-a, de prática, em conceito: com o enfraquecimento da política e a influência do pensamento cristão, a tradição filosófica ocidental separou a liberdade da política, situando-a no nível da vontade e do pensamento do indivíduo - do "mundo", a liberdade passaria ao "eu". Como diz a autora:

Nem o coração nem a mente, mas a interioridade, como região de absoluta liberdade dentro do próprio eu, foi descoberta na Antiguidade tardia por aqueles que não possuíam um lugar próprio no mundo [...]. A teoria de que “a região apropriada da liberdade humana" é o "domínio interno da consciência" surge com maior clareza se voltarmos às suas origens. Não é representativo a esse respeito o indivíduo moderno, com seu desejo de se desdobrar, desenvolver e expandir [...], mas os sectários populares e popularizantes da Antiguidade Tardia que dificilmente tinham qualquer coisa em comum com a Filosofia além do nome. Assim, os argumentos mais convincentes para a absoluta superioridade da liberdade interna ainda podem ser encontrados em um ensaio de Epicteto, que começa afirmando que livre é aquele que vive como quer, uma definição que curiosamente faz eco a uma sentença da Política de Aristóteles na qual a asserção "a liberdade significa fazer um homem o que deseja" é posta nos lábios daqueles que não sabem o que é liberdade (ARENDT, 2005, pp. 192-3). 
A liberdade, que durante a antiguidade foi um tema político que escapava à filosofia, tornou-se um tema filosófico por meio do deslocamento da liberdade do mundo público à interioridade do eu, que encontraria pleno desenvolvimento da filosofia agostiniana do livre-arbítrio e que informaria a filosofia política moderna de Rousseau a Stuart Mill. No decorrer do texto, a autora argumenta em defesa da retomada da noção política da liberdade, daí a ironia da "intertextualidade" entre Epicteto e Aristóteles, na qual o primeiro é o mau exemplo citado pelo segundo. Mas o que seria essa liberdade política, anterior à "interiorização" filosófica do tema?

A autora argumenta que, longe de ser entendida como parte do pensamento ou da vontade individual, a liberdade era pensada e vivida na Antiguidade como um "estado de ser manifesto na ação", que se realiza no quadro da polis. A autora utiliza diversos caminhos para pensar o estatuto da ação política livre, dentre os quais dois serão retomados aqui: a metáfora da política com a arte de realização virtuosa e a reflexão sobre o caráter "miraculoso" da política.

Segundo Hannah Arendt, a ação política não se assemelha às "artes de criação", que produzem um objeto que terá uma existência própria, como um artesão que produz uma mesa ou um ceramista que produz um vaso. Mais adequado ao exercício político da liberdade é o paralelo deste com as "artes de realização", as quais, ao contrário das artes de criação,

têm com efeito uma grande afinidade com a política. Os artistas executantes - dançarinos, atores, músicos e o que o valha - precisam de uma audiência para mostrarem seu virtuosismo, do mesmo modo como os homens que agem necessitam da presença de outros ante os quais possam aparecer; ambos requerem um espaço publicamente organizado para sua "obra", e ambos dependem de outros para o desempenho em si. Não se deve tomar como dado um tal espaço de apresentações sempre que os homens convivem em comunidade. A polis grega foi outrora precisamente a "forma de governo" que proporcionou aos homens um espaço para aparecimentos onde pudessem agir uma espécie de anfiteatro onde a liberdade podia aparecer. (ARENDT, 2005, p. 201).

Deste modo, a política é ação, execução virtuosa feita em público, diante dos outros que ao mesmo tempo são audiência e pressupostos da execução. A polis como anfiteatro da liberdade, metáfora que associa a política à arte, não de criação, mas de 
realização - a liberdade se realiza como ação no mundo público. Sendo assim, a liberdade está no relacionamento com os outros e não na interioridade do eu, como queria a tradição cristã e a fillosofia política moderna que acabaram por equacionar a liberdade ao "livre-arbítrio". Esta equação, segundo a autora, aprisiona a liberdade nos domínio da vontade do indivíduo, que busca dominar a si e eventualmente expandir seu domínio sobre os outros - o resultado imediato é o surgimento do ideal de soberania, da soberania de si sobre si mesmo, do eu sobre os outros. A teoria da soberania afirma que a liberdade de uma comunidade só pode ser adquirida ao preço da liberdade dos indivíduos, e este é o fundamento da opressão e da tirania: a soberania só pode ser mantida pela violência, ou seja, "com meios essencialmente não-políticos" (ARENDT, 2005, p. 213).

É preciso, portanto, resgatar o sentido político da liberdade, de vida com os outros, de arte de realização, de modo a libertá-la da opressão do eu e da soberania da vontade. E é justamente na tradição cristã, que equacionou liberdade e livre-arbítrio, que a autora vai encontrar uma concepção propriamente política da liberdade: o milagre, a ação inesperada. Retomando Santo Agostinho, algumas passagens do Evangelho e a etimologia da palavra grega arkhein (começar, agir, governar), Hannah Arendt pensa a liberdade como faculdade humana de começar, contra os processos de petrificação e automatismo do mundo natural e humano:

Sem dúvida nenhuma a vida humana situada sobre a terra é circundada por processos automáticos: pelos processos terrestres naturais, por seu turno envolvidos por processos cósmicos e sendo nós mesmos impelidos por forças similares na medida em que fazemos parte também de uma natureza inorgânica. Nossa vida política, além disso, a despeito de ser o reino da ação, faz parte também destes processos que denominamos históricos e que tendem a se tornar tão automáticos como os processos cósmicos e naturais, embora tenham sido acionados pelo homem. [...] Uma vez que processos históricos e artificiais se tenham tornado automáticos, não são menos destruidores que os processos vitais naturais que dirigem nosso organismo e que em seus próprios parâmetros, isto é, biologicamente, conduzem do ser para o não-ser, do nascimento para a morte. [...]

O que normalmente permanece intacto nas épocas de petrificação e de ruína inveitável é a faculdade da própria liberdade, a pura capacidade de começar, que anima e inspira todas as atividades humanas e que constitui a fonte oculta de todas as coisas grandes e belas. Mas enquanto essa fonte 
permanece oculta, a liberdade não é uma realidade tangível e concreta: isto é, não é política. [...] Em tais circunstâncias, a liberdade não é vivenciada como um modo de ser com sua própria espécie de "virtude" e virtuosidade, mas como um dom supremo que somente o homem, dentre todas as crituras terrenas, parece ter recebido, e cujos sinais e vestígios podemos encontrar em quase todas as suas atividades, mas que, não obstante, só se desenvolve com plenitude onde a ação tiver criado seu próprio espaço concreto onde possa, por assim dizer, sair de seu esconderijo e fazer sua aparição. (ARENDT, 2005, pp. 217-8).

A autora, portanto, discrimina dois tempos da liberdade: um, no qual a liberdade é oculta (ainda que seus vestígios sejam visíveis), reina o automatismo das relações sociais, dos processos históricos; outro, no qual a liberdade se realiza plenamente, a faculdade humana de começar, de alterar os processos automáticos da história, aparece enquanto ação política, em seu "espaço concreto de aparição" - como a polis, anfiteatro da liberdade.

A liberdade política de Hannah Arendt se volta contra a História, entendida como automação das relações sociais; é uma quebra na temporalidade cujo horizonte é o não-ser, um salto contra a previsibilidade do mundo: em uma palavra, um milagre. $\mathrm{E}$ assim como o automatismo não é específico do mundo natural, como se observa na petrificação da vida política e da história, o milagre não é específico do mundo humano: diversos processos naturais, como o surgimento da vida e a evolução humana, constituem milagres, o que a autora denomina de "improbabilidades infinitas" que interrompem o automatismo cósmico. As "improbabilidades infinitas" da realidade humana, bem mais freqüentes na história do que na natureza, se devem justamente à faculdade de começar, da liberdade presente em todas as ações humanas, que se torna plena quando realizada no espaço público diante dos e com os outros.

Depois deste longo percurso, podemos voltar à definição de política que a autora da no início do texto: "a raison d'être da política é a liberdade, e seu domínio é a experiência e a ação". Liberdade como faculdade humana de começar, de criar as "improbabilidades infinitas" que interrompem os processos históricos automáticos; experiência e ação como execução virtuosa da liberdade, diante dos e com os outros homens. O grande apoio para o percurso filosófico de Que é liberdade? é a polis, espaço-tempo em que a liberdade foi realizada plenamente: é contra a experiência da polis que se equacionou a liberdade com o livre-arbítrio, e é recorrendo à experiência da 
polis (romana) que a autora explica como Santo Agostinho formulou o conceito de liberdade como faculdade de começar. E aqui é o ponto em que se pode perguntar: o que era a política na democracia ateniense do período clássico, a partir das reflexões de Hannah Arendt sobre a política? Estaria a política confinada aos cidadãos ${ }^{70}$, ou o exercício da liberdade como ação miraculosa se encontraria também entre mulheres, escravos, metecos?

Ora, se a liberdade é a faculdade humana de começar, de interromper os processos históricos automatizados, e a polis aparece como a concretização de um espaço onde a liberdade é executada publicamente como virtuosismo, certamente a resposta seria que apenas os cidadãos, ou seja, aqueles que possuíam o privilégio da "aparição política" no anfiteatro-polis, exerceriam a política. No entanto, o mesmo raciocínio pode ser utilizado para se pensar a própria "concretização" da polis: a restrição do acesso de não-cidadãos ao "anfiteatro político" da polis, ou seja, as instituições determinadas como políticas pelo corpo cívico (Assembléia, Conselho, Tribunal), também é um processo de automatização: a institucionalização da política como privilégio dos cidadãos em espaços restritivos é em si mesma um modo de petrificação das relações sociais. Os cidadãos agem/começam/governam, e disso excluem os outros, os não-cidadãos, e assim deve continuar sendo. "A liberdade dos cidadãos é a não-liberdade dos não-cidadãos", isso é um truísmo; no entanto, o que dizer quando este monopólio é questionado, quando os não-cidadãos tomam parte dos movimentos de quebra dos processos históricos, em maior ou menos grau de aparição? O que dizer quando o automatismo da "polis como comunidade de cidadãos" é quebrado, e surge uma experiência da polis como espaço de habitantes, cidadãos ou não? Ou quando o espaço da casa, da rua, do porto e mesmo do tribunal, passa a conter ações que ultrapassam a especialização determinada pelo discurso cívico, entre as quais, está a participação política de habitantes? Ou quando os metecos, excluídos de qualquer atividade política, são qualificados como "democratas", ou seja, quando um

${ }^{70}$ Esta é a visão da própria Hannah Arendt em $A$ Condição Humana: fundando-se em Aristóteles e na historiografia produzida no século XIX e início do XX, a autora aceita a visão de que a polis é uma “comunidade de cidadãos", ou seja, metecos, mulheres e escravos não compartilhariam deste modo de vida livre fundado na aparição da ação. Cf. ARENDT (2007, pp. 31-46). Um desenvolvimento da idéia arendtiana de espaço da liberdade no sentido da formação de uma identidade política, mas também restrita aos cidadãos, está em C. Meier (1995). 
qualificativo político é dado a um indivíduo privado da política? Ou quando um meteco se põe a teorizar sobre a polis (Aristóteles), e outro a escrever discursos que (des)constroem memórias e identidades da polis (Lísias)?

A meu ver, a institucionalização da política como privilégio cívico faz parte dos processos históricos automáticos, que, no entanto, se apresentam de modo diferenciado para cidadãos e para não-cidadãos. Para os primeiros, é o pressuposto da ação política livre; para os últimos, a barreira para tal ação. No entanto, mesmo quando o espaço concreto para a liberdade não existe, como diz Hannah Arendt, ou, pode-se dizer, não existe para todos, não significa que a liberdade como faculdade de começar tenha desaparecido. Nos termos da autora, e ao mesmo tempo desviando a política para além da "liberdade plena", acredito ser possível dizer que, se os cidadãos exerciam a liberdade política plena na "polis-comunidade de cidadãos", os não-cidadãos exerciam a "liberdade oculta" na "polis-comunidade de habitantes"; tal liberdade oculta, a política dos não-cidadãos, deixava vestígios que podem ser encontrados na cultura material, na filosofia e na comédia, como argumentou Marta M. de Andrade (2000), e na oratória, particularmente nos discursos de Lísias, como tenho argumentado nesta dissertação.

Mas qual é o lugar da realização da política dos não-cidadãos, desta liberdade oculta, que deixa vestígios mais ou menos indiretos na documentação? Qual é o espaçotempo no qual o trabalho morto social, a polis e suas instituições, é repetido e/ou interrompido em seu fluxo, ou seja, onde a faculdade de começar é executada visando a própria polis? Para tal questão, tão pouco feita à documentação, uma problemática parece particularmente fecunda: a problemática do cotidiano.

\section{O cotidiano como questão}

O cotidiano é geralmente tomado como o tempo por excelência da repetição, do automatismo, do banal, do homogêneo. Não poucas vezes, a vida cotidiana foi confundida com a vida privada: banhar-se, comer, beber, dormir etc ${ }^{71}$. Haveria, pois, política no cotidiano, $n a$ vida cotidiana? Se resumiria o cotidiano ao repetitivo, levando

\footnotetext{
${ }^{71}$ Ver, a esse respeito, o debate sobre a história da vida privada no volume 4 dos Anais do Museu Paulista, de 1996, em especial a polêmica entre Ronaldo Vainfas e José de Sousa Martins. A crítica deste último foi publicada também em Martins (2000, pp. 93-109).
} 
a política a um "nível" não-cotidiano? O objetivo da discussão a seguir não é fazer um levantamento exaustivo da questão do cotidiano nas ciências humanas, empresa que ultrapassaria em muito as possibilidades da presente pesquisa; procura-se, ao invés disso, formular uma problemática da política em relação ao cotidiano, ou do cotidiano em relação à política, que apresente possibilidades para se discutir a ação política dos não-cidadãos na polis ateniense.

A vida cotidiana como tema literário tem uma longuíssima história, que pode ter como início as descrições etnográficas de Heródoto, e como ponto de inflexão fundamental a literatura e a antropologia do século XIX. No entanto, será apenas no início do século XX que o cotidiano se tornou um tema da especulação fillosófica e da análise científica, em particular com a "virada ontológica" de Heidegger em Ser e Tempo, no qual a vida cotidiana é tomada como o reino da inautenticidade e da impropriedade, contra a qual o Ser se reconheceria no ser-para-a-morte. Uma das principais respostas à abordagem heideggeriana da cotidianidade foi elaborada por Lukács em suas reflexões ontológicas e estéticas: contra a impossibilidade de uma vida cotidiana autêntica, tal como pensava Heidegger, Lukács pensa a vida cotidiana como a reprodução da vida do "homem inteiro", da qual surgem tanto a ciência quanto a arte, indicando assim as possibilidades de uma negação da alienação cotidiana que não fosse o movimento do ser-para-a-morte de Heidegger.

Deste debate, duas linhas de estudos sobre o cotidiano foram desenvolvidas em meados do século XX, a partir tanto da rediscussão das leituras de Heidegger e Lukács, quanto da análise das transformações históricas do capitalismo e do socialismo na época: primeiro, uma forma de ver o cotidiano como um nível da vida específico de determinadas sociedades, em particular a moderna capitalista; segundo, a abordagem que vê o cotidiano como categoria ontológica, universal dos seres humanos. Grosso modo, os autores que representam estas linhas são, respectivamente, Henri Lefebvre, nas diversas etapas de sua Crítica da vida cotidiana (1947, 1958, 1961, 1981), e Agnes Heller, em sua Sociologia da vida cotidiana (1970).

No campo da historiografia, um dos mais importantes trabalhos sobre o cotidiano é a obra dirigida por Michel de Certeau, A Invenção do Cotidiano, de 1994. Debatendo principalmente com a análise do poder de Michel Foucault (as obras de Lefebvre e Heller aparecem apenas tangencialmente), de Certeau argumenta que, oposta às estratégias de dominação (operadas no nível macro pelas instituições e no micro 
pelos dispositivos e técnicas do poder), existe uma vasta gama de táticas de resistência, de apropriação e modificação dos regimes de controle: o estudo histórico do cotidiano se propõe a abordar as redes de "anti-disciplina", de "anti-poder", como táticas de praticantes. No entanto, ainda que de Certeau formule o cotidiano como momento de luta e tensão, ele não assume o ponto de vista da totalidade, fazendo com que o emaranhado de táticas e resistências se dilua na prática política e cultural ${ }^{72}$.

A apropriação da crítica do cotidiano tem sido feita, no Brasil, particularmente pelos esforços da sociologia e da geografia urbana, de inspiração fortemente lefebvriana (Martins, 2000); somente nos últimos tempos, a historiografia brasileira tem se voltado para o tema do cotidiano, inspirada principalmente na obra de Agnes Heller e Michel de Certeau, e menos em Henri Lefebvre. Superando a naturalização do cotidiano como vida privada, a historiografia brasileira do cotidiano tem se voltado para as historicidades apagadas ou submetidas, revelando assim rupturas ou possibilidades de rupturas das estruturas mais gerais das diferentes sociedades. Dois estudos inovadores que podem ser citados nesta direção, dentro da historiografia brasileira, são: a tese de Marta Mega de Andrade, que trata das relações entre espaço e vida cotidiana na sociedade ateniense clássica, e o artigo de Norberto Guarinello, que discute a crise da historiografia e relação entre cientificidade da história e história do cotidiano.

$\mathrm{Na}$ discussão a seguir, serão retomadas as duas linhas de pesquisa do cotidiano acima citadas (nível histórico-específico e categoria ontológica) a partir da argumentação de Henri Lefebvre e Marta de Andrade, na primeira linha, e de Agnes Heller e Norberto Guarinello, na segunda.

\section{Cotidiano e estilo de vida em Henri Lefebvre e Marta de Andrade}

Henri Lefebvre inicia sua reflexão sobre o cotidiano no pós-libertação da França com o fim da Segunda Guerra Mundial: é no contexto de reconstrução e proposição de novas realidades que aparece, em 1947, o primeiro volume da Critique de la vie

\footnotetext{
${ }^{72}$ Ver por exemplo as críticas de John Roberts $(1999,2006)$, para quem a abordagem de de Certeau faz parte da chave "pós-moderna" que resume a contestação social às políticas de representação ou políticas culturais, "separadas de qualquer engajamento estrutural com os problemas de distribuição material ou justiça econômica" (ROBERTS, 1999, p. 28).
} 
quotidienne, onde surge o conceito de cotidianidade como tensão dialética entre a realização da humanidade do homem e sua alienação pelo capital, que resultou no desprezo da filosofia em relação à vida cotidiana: o fato dos filósofos modernos terem se colocado num plano superior, acima da cotidianidade, apenas revela que a vida cotidiana se cindiu na modernidade. O tema será retomado em 1958, quando o autor escreve uma nova introdução à segunda edição da Critique: neste texto, o autor faz uma rediscussão de seus fundamentos metodológicos, insistindo na importância da noção de totalidade, contra o parcelamento das análises do cotidiano.

A rediscussão da "introdução de 1958" leva à publicação, em 1961, do segundo volume da Critique de la vie quotidienne (Fondemments pour une sociologie de la quotidienneté), livro central na produção lefebvriana, no qual o autor realiza uma ampla discussão sobre instrumentos conceituais possíveis em seu projeto: os níveis, a totalidade, a espontaneidade, a ambigüidade, a alienação, além da formulação das teorias "da necessidade", "do campo semântico" e "dos momentos". O tema será retomado ainda em dois livros: uma obra de divulgação, $A$ vida cotidiana no mundo moderno, de 1968, e o terceiro volume da Critique, de subtítulo De la modernité au modernisme (Pour une métaphilosofie du quotidien), de 1981, que introduz alguns conceitos como a "ritmanálise" e discute o impacto das empresas multinacionais no cotidiano.

Uma definição do conceito de cotidiano em Lefebvre é praticamente impossível, não apenas pelas variações que o conceito sofre em mais de trinta anos (de 1947 a 1981) ou pelo modo característico de escrita do autor, mas também pela própria abordagem do autor: o cotidiano é indefinível.

Em um sentido, a vida cotidiana, é o que há de mais simples, de mais evidente. Como se vive? Se é difícil responder, a questão não é menos clara. Em outro sentido, [a vida cotidiana] é o que há de mais inescapável, de mais difícil de discernir e determinar. Em um sentido, nada mais superficial: é a banalidade, a trivialidade, o repetitivo. Em outro sentido, nada de mais profundo. É a existência e o "vivido" não transcritos especulativamente, revelados; é o que se deve mudar e o que há de mais difícil de mudar. (LEFEBVRE, 1961, p. 52).

Disto resulta que a vida cotidiana é marcada fundamentalmente pela ambigüidade: a um passo superficial e profunda, a vida cotidiana não se constitui como 
objeto puro na medida em que o observado também está inserido nela. O projeto de crítica da vida cotidiana se realiza por meio de aproximações, envolvendo tanto os conceitos abstratos da filosofia (necessidade, desejo, motivação) quanto a observação empírica das ciências sociais (modos de consumo, temporalidades rurais e urbanas, cristalização de rotinas e aparecimento de criações etc); a premissa destas aproximações é que a compreensão da vida cotidiana não pode estar dissociada do conhecimento da sociedade inteira: é visando a totalidade que se erige o projeto. Assim, não se pode deslocar a vida cotidiana do processo geral de reprodução das sociedades: cada sociedade tem sua temporalidade específica (relações entre o tempo cíclico e o tempo linear), apresentando assim um cotidiano específico.

Na sociedade capitalista, com o desenvolvimento do consumo de massa, ocorre uma cisão entre necessidades e desejos, no qual o consumidor é motivado a desejar o desnecessário, e a necessitar do indesejado, por meio de tecnologias específicas - a vida cotidiana é banalizada, rompida, por meio da alienação extrema da "sociedade de consumo dirigido". Mas seria, segundo Lefebvre, possível um outro cotidiano no capitalismo? Ou ainda: teriam existido outros cotidianos antes do capitalismo?

Para a primeira questão, de central importância é a "teoria dos momentos", presente do segundo volume da Critique. Para Lefebvre, contra a alienação e a banalidade da vida tornada cotidiana, surgem momentos de criação de outras formas de vida: o momento "tem lugar não somente pela liberdade, uma liberdade limitada mas real (que se constitui ao estruturar, desestruturar ou reestruturar a vida cotidiana) mas também pela invenção e a descoberta" (LEFEBVRE, 1961, p. 353). Seria o momento um tempo político? O autor, ao que parece, tende a equacionar a política ora com o Estado, ora com o poder, e a teoria dos momentos passa sem uma reflexão política.

Para a segunda questão, as respostas variaram de acordo com os textos analisados. Nos três volumes da Critique, assim como em outros livros, os termos vida cotidiana, cotidiano e cotidianidade são usados com certa liberdade: se são em um parágrafo definidos, em outro são relativizados. No entanto, em $A$ vida cotidiana no mundo moderno, único livro do autor sobre o cotidiano traduzido para o português, $\mathrm{H}$. Lefebvre é bastante enfático ao afirmar que a cotidianidade é específica do capitalismo, contraposta aos "estilos de vida" existentes nas sociedades pré-modernas. Segundo o autor,

entre os incas ou os astecas, na Grécia ou em Roma, um estilo caracterizava os mínimos detalhes: gestos, palavras, instrumentos, objetos familiares, 
vestimentas etc. Os objetos usuais, familiares (cotidianos), ainda não tinham caído na prosa do mundo. E a prosa do mundo não se separava da poesia. Nossa vida cotidiana se caracteriza pela nostalgia do estilo, por sua ausência, e pela procura obstinada que dele empreendemos. (LEFEBVRE, 1991, p. 36).

Assim, contraposta à cotidianidade alienada do mundo moderno, estaria o estilo de vida das sociedades antigas. A vida cotidiana se torna, pois, de fato em si (o banal, o repetitivo), em campo de investigação: como cada sociedade produzia seu cotidiano, como um nível específico da vida, com ou sem estilo? Não se trata mais de se pensar o cotidiano como a vida privada, ou como os costumes apresentados de modo mais ou menos anedótico, mas sim de discutir a produção da vida cotidiana a partir da totalidade da sociedade: o cotidiano se torna um caminho para se compreender a reprodução global da sociedade, suas tensões, seus conflitos. O cotidiano não é um pressuposto ontológico de todas as sociedades humanas, mas é um nível da vida produzido de modos específicos e por sociedades específicas.

Esta é a linha desenvolvida pela historiadora Marta de Andrade em seu estudo “A vida Comum”, citado diversas vezes nesta dissertação. Contra a tradição antiquária das "histórias do cotidiano", que reificavam o cotidiano moderno e o projetava para as sociedades antigas, a historiadora procura, a partir da sugestão lefebvriana do "estilo de vida", pensar os modos pelos quais era construída uma experiência específica da vida, a "vida no dia", na documentação disponível. Assim, comparando O Trabalho e os Dias de Hesíodo e os textos atenienses do período clássico, a autora formula a hipótese de que, com o processo de urbanização do $\mathrm{V}$ século a. C., as noções que se referem à vida de cada dia (derivadas do grego hemeros, "o dia") são espacializadas: se no texto de Hesíodo a vida cotidiana tem uma marcação temporal (o dia, as atividades no dia), nos autores do período clássico (Aristófanes, Platão, Aristóteles) a vida cotidiana se refere cada vez mais a um espaço onde ocorrem determinadas interações sociais: os encontros na rua, as relações familiares na casa ou fora dela, os banquetes etc - ou seja, a interações entre habitantes, e não somente entre cidadãos. Ao lado da espacialização da vida cotidiana, ocorrem mudanças na noção de "habitar": se em Hesíodo habitar é um fato genérico do homem, nos textos clássicos o habitar é uma atividade cotidiana, associada ao que seria uma "vida doméstica" (kath'oikian). 
A partir disso, a autora observa que, no período clássico, o cotidiano é construído como uma "dimensão do tempo-espaço da vida social” (ANDRADE, 2002, p. 89), na qual as interações sociais não estavam restritas aos cidadãos, mas nela interagiam os habitantes da polis. Não se trata, pois, de se fazer a história do cotidiano em Atenas através das descrições dos banhos, dos banquetes, dos quartos, dos rituais de casamento; trata-se de analisar de que modo as fontes constroem o cotidiano como uma dimensão, um nível específico da vida. Neste sentido, a autora aborda a questão das estratégias de dominação e táticas de resistência (inspirada em Michel de Certeau) nos usos do espaço urbano da polis ateniense: estratégias dos cidadãos, procurando regular a apropriação do espaço pelos habitantes, táticas dos habitantes, propondo e praticando outros usos, fora do discurso cívico. As categorias deste discurso, em particular a oposição entre público/privado como oposição espacial entre polis/oikos, reproduzida pela historiografia, é interpretada como estratégia cívica sobre a apropriação cotidiana do espaço urbano.

Haveria política no tempo-espaço cotidiano ateniense no período clássico? Como já foi indicado, no livro de 2002 a autora trabalha com a categoria de política como prática exclusiva dos cidadãos, contra a qual se insurgem táticas de habitantes. De qualquer maneira, acredito que, se retomarmos a discussão arendtiana de política, como liberdade de começar, é possível pensar o cotidiano como dimensão específica da vida na qual os habitantes podem exercer essa liberdade, ou seja, o cotidiano se torna o tempo-espaço possivvel da política dos não-cidadãos. Esta questão será retomada adiante; antes, passemos à segunda linha da análise do cotidiano, entendido como categoria ontológica.

As estruturas do cotidiano em Agnes Heller e Norberto Guarinello

Agnes Heller, aluna de G. Lukács e uma das fundadoras da célebre Escola de Budapeste, teve sua trajetória intelectual fortemente marcada pela história do socialismo na Hungria: Heller formula sua problemática da vida cotidiana diante da intensificação do estalinismo na política húngara, que resultaria em seu exílio em 1977, e da afirmação das abordagens estruturalistas no marxismo das décadas de 50 e 60, que diluiam ação humana subjetiva dentro das grandes estruturas econômico-sociais - a questão da ética e da liberdade é central em seus estudos, como se observa em seus estudos sobre moral e 
papéis sociais, ou até mesmo em estudos históricos, como o escrito acerca do renascimento italiano. De qualquer modo, esta problemática da ética e da liberdade deu origem a um livro que Lukács consideraria "um dos estudos mais importantes de todo o campo de investigação sobre a gênesis e o devir do ser social concreto" (LUKÁCS, 1977): trata-se da Sociologia da Vida Cotidiana, escrito em 1970, estudo amplo e sistemático sobre os conceitos fundamentais para tal sociologia, e que seria sintetizado em um texto intitulado "Estrutura da Vida Cotidiana", escrito no mesmo ano.

Segundo a autora, todo ser humano tem uma vida cotidiana, onde ocorre a reprodução do homem particular; no entanto, esta reprodução cotidiana da particularidade contém a genericidade do ser humano: um exemplo é o trabalho, que "tem frequentemente motivações particulares, mas a atividade do trabalho - quando se trata de trabalho efetivo (isto é, socialmente necessário) - é sempre atividade do gênero humano" (HELLER, 2008, p. 36). A vida cotidiana é a vida do "homem inteiro", onde estão colocados todos os aspectos de sua individualidade, mas onde nenhum é realizado em toda sua intensidade; o ser humano se reproduz como uma "unidade muda entre particularidade e genericidade", na qual o indivíduo particular raramente se eleva, conscientemente, às atividades humano-genéricas: a cotidianidade é marcada pelo aprendizado das regras sociais, pela adaptação às instituições, pela satisfação das necessidades vitais etc.

Assim, a cotidianidade é ontológica, todos os homens tem vida cotidiana, de todos os tempos e espaços; apesar de variarem os conteúdos (as atividades, os lugares) e as hierarquias (o valor para cada atividade), a cotidianidade tem uma estrutura formal, de acordo com características que a diferem das atividades humano-genéricas, como a arte, a ciência, a política, a religião etc ${ }^{73}$.

\footnotetext{
${ }^{73}$ Em resumo, a autora menciona as seguintes estruturas. Espontaneidade: a repetição das regras e normas sociais, das modas, dos costumes, exige que cada indivíduo não reflita sobre cada um de seus atos, mas que os pratique espontaneamente, adaptando, com maior ou menor liberdade, suas motivações particulares às exigências sociais. Probabilidade: sendo impossível o cálculo científico para se determinar as conseqüências exatas de cada ação cotidiana, a ação social se orienta de acordo com as noções de caso médio e suficiência; caso as considerações probabilísticas fracassem, ocorrem as "catástrofes cotidianas". Economicismo: a ação e o pensamento cotidiano orientam-se para a simples reprodução da cotidianidade, ou seja, quando são imprescindíveis; quando a ação e o pensamento se orientam para fora do cotidiano ("para cima", na direção do humano-genérico, ou "para baixo", na incapacitação da vida), a vida cotidiana fica em risco. Pragmatismo: na vida cotidiana o pensamento não se eleva em teoria, e a ação em
} 
No entanto, e justamente por esta estruturação, a vida cotidiana não é uma prisão intransponível: o homem pode se elevar acima da cotidianidade na medida em que, como indivíduo consciente tanto de sua particularidade quando dos aspectos genéricos, consegue promover uma homogeneização de sua ação. Esta "homogeneização", que é a saída da cotidianidade, é caracterizada por três fatores: a concentração em uma única atividade, a suspensão da particularidade e a liberdade individual - com isso, o indivíduo particular passa de "homem inteiro" a "homem inteiramente", ou seja, de uma condição em que suas potencialidades eram todas usadas ao mesmo tempo (sem que nenhuma se intensificasse), em que sua vida era mera repetição das normas sociais aplicadas ao seu ser particular, para uma condição na qual o indivíduo particular age como representante do gênero humano, como "protagonista do processo histórico global". Quem são aqueles que conseguem ultrapassar a fronteira (que varia historicamente) da cotidianidade? Segundo A. Heller, o moralista, o estadista, o revolucionário, o artista e o cientista são indivíduos "cuja paixão dominante se orienta para o humano-genérico e, ademais, quanto tem a capacidade de realizar tal paixão"; para eles, a 'homogeneização em 'homem-inteiramente' é elemento necessário de sua essência, da atividade básica de suas vidas" (HELLER, 2008, p. 46).

Ora, esta possibilidade existe para uma ínfima minoria da humanidade. Seria possível uma emancipação total da humanidade? Heller enxerga na superação da alienação da vida cotidiana no capitalismo o momento dessa emancipação. Para a autora, nem toda vida cotidiana é alienada, mas é sob o capitalismo que a alienação chega ao limite: com o desenvolvimento industrial moderno, existe um abismo entre a capacidade de produção humano-genérica e a participação individual consciente nesta produção $^{74}$ - assim, apenas com a abolição desta alienação todos os indivíduos

práxis, pois só o fazem quando se elevam para o humano-genérico; existe uma unidade imediata entre pensamento e ação, orientados para a particularidade, para as ações cotidianas. Ultrageneralização: a ação cotidiana se orienta por meio de juízos provisórios, que, se suficientes para a realização de determinadas ações, são generalizados para todas as outras situações; são casos desta ultrageneralização a orientação pela analogia e por precedentes. Imitação: a assimilação dos costumes não se dá de acordo com preceitos abstratos, mas pela imitação dos outros; cada situação apresenta um grau específico de liberdade do indivíduo, que vai desde a necessidade na imitação absoluta à possibilidade de criar o novo (HELLER, 2008, pp. 47-56).

${ }^{74}$ Vale notar que a autora não isenta as sociedades socialistas da alienação da cotidianidade: na medida em que o direito e o Estado são fenômenos da alienação, também o direito e o Estado socialistas, que 
particulares serão livres para desenvolverem-se, criando uma "condução da vida" específica, pela qual cada ndivíduo se apropria da realidade à sua maneira tendo em vista não a particularidade, mas a humanidade como um todo - uma nova cotidianidade nasceria (HELLER, 2008, p. 61).

Haveria política na vida cotidiana segundo Agnes Heller? A política aparece no texto como atividade humano-genérica, "acima" da cotidianidade: na Sociologia da vida cotidiana, a autora define política como "toda ocupação desenvolvida com a cosciência de nós no interesse de uma determinada integração" (HELLER, 1977, p. 172) - quando tal ocupação tem lugar, deixa-se a vida cotidiana. Mas não poderia a política tornar-se uma atividade cotidiana? Em uma passagem de sua Sociologia, diz a autora:

Somente os membros dos estratos e classes dominantes em cada época tiveram maiores possibilidades de ocupar-se também de política em sua vida cotidiana, enquanto que para os explorados e os carentes de poder foi possível em menor grau o exercício de uma atividade política que transformasse o status quo. Mas isso não significa que todo membro da camada dirigente, da classe dominante foi politicamente ativo na vida cotidiana (aparte algumas exceções, como por exemplo o apogeu da antiga polis). (HELLER, 1977, p. 174).

O cotidiano pode se tornar político: no sentido da dominação, para a classe dirigente, e no da transformação, para os explorados. A "antiga polis" aparece como exemplo (excepcional) do engajamento cotidiano massivo da classe dominante (é lícito supor: os cidadãos) na política. Como se relacionam as estruturas da cotidianidade com a atividade política? Infelizmente, a autora não desenvolve o tema, e mantem a cisão entre política e cotidiano. De qualquer maneira, fica indicada a possibilidade de uma cotidianização da política, no sentido da dominação dos cidadãos sobre os nãocidadãos. Mas podemos prosseguir com a linha de raciocínio: assim como os explorados também cotidianizam a política no sentido da transformação, não seria possível pensar que os não-cidadãos da "antiga polis" também o fizessem? Neste sentido, uma política dos não-cidadãos se realiza no cotidiano por meio da contestação, da produção de novos conteúdos e hierarquias; no caso dos metecos, a produção de uma memória que os

impedem que as particularidades individuais se desenvolvam na direção do humano-genérico, mantem a alienação - cabe à sociedade organizada libertar-se por meio de uma democracia socialista (HELLER, 1977, p. 184-5). 
coloca como participantes ativos da restauração democrática seria um exemplo eloqüente: o cotidiano judiciário apresentaria uma via para essa participação, na medida em que a logografia não é restrita aos cidadãos. Analisar essa "brecha logográfica" pode ser um meio de se pensar essa participação política cotidiana, na qual as hierarquias e valores produzidos pelo passado são "presentificados", ocorrendo assim a produção do novo.

Essa idéia do cotidiano como presente é desenvolvida pelo historiador Norberto L. Guarinello, em texto intitulado História Científica, história contemporânea e história cotidiana, de 2004. Discutindo a chamada "crise da História", o autor explora as possibilidades de se pensar o cotidiano como categoria da análise historiográfica, ultrapassando com isso a oposição entre estrutura e ação, entre determinação e liberdade no devir das sociedades. Como Agnes Heller, Norberto Guarinello toma o cotidiano como categoria ontológica: todas as sociedades humanas de todas as épocas têm um cotidiano. Mas o que é o cotidiano? Contra uma dicotomia entre cotidiano ("longa duração") e história ("acontecimentos"), o autor ressalta a dualidade na própria etimologia: "na origem latina, quot dies é, ao mesmo tempo, um dia e todos os dias" (GUARINELLO, 2004, p. 25). Sendo assim, no próprio “cotidiano" está o acontecimento e a longa duração - mas seria possível, questiona o autor, superar essa dicotomia?

O acontecimento não é assim o inesperado, o imprevisto, não surge do nada, mas é um produto do cotidiano. Não há por que separar os dois planos ou, dito de outro modo, talvez seja útil pensá-los conjuntamente.

Daí que proponho ver o cotidiano não como uma esfera da vida, mas como um tempo, como um momento, um presente que, visto em perspectiva, congrega uma sucessão de presentes no fluxo contínuo da vida. Associar cotidiano a presente tem conseqüências importantes para o modo como encaramos a história. $\mathrm{O}$ presente que não é mera repetição do passado, mas um campo de restrições e possibilidades em aberto para projetos alternativos de futuro. O presente, entendido como o dia de hoje, é como o vértice de uma tríade temporal que forma, com passado e futuro, o curso da história. (GUARINELLO, 2004, pp. 25-6).

É por meio do cotidiano como "presente" que o autor abre o cotidiano como “campo de restrições e possibilidades", no qual está posta tanto a repetição quando a transformação. Mas esse campo não se apresenta de modo desordenado, caótico: todo o 
presente se depara com uma "armação da vida" já estabelecida no passado, ou em diferentes "espessuras do passado" (GUARINELLO, 2004, p. 27), com a qual todos os homens precisam se defrontar, seja para reproduzir, seja para modificar - trata-se do trabalho morto social, trabalho acumulado pelas sociedades em sua relação com o mundo humano e natural. Trabalho morto é tanto o idioma quanto o fogo, as máquinas ou as identidades, as ordens sociais ou os modos de contestação - tudo o que é produzido, selecionado e transmitido, do passado ao presente. A ação humana, portanto, presentifica o trabalho morto no tempo cotidiano, quando não há mais oposição entre estrutura e ação. $O$ autor discute algumas estruturas da vida cotidiana, que representariam os "fundamentos da ação social sobre o capital acumulado apresentado a cada dia pelo passado"75 (GUARINELLO, 2004, p. 28), além de desenvolver as consequências dessa mudança de foco (da estrutura/ação à vida cotidiana) para a historiografia. Aqui, entretanto, gostaria de retomar algumas das reflexões do autor acerca da inovação no cotidiano. Após discutir as forças de reprodução e as possibilidades de modificação da vida passada, afirma o autor:

O presente, em suma, aparece-nos como dado, como estruturado independentemente de nossa vontade, como trabalho morto, que devemos aceitar ou não, reproduzir ou não, a cada dia, ou a cada ciclo de dias. Essa estrutura, esse trabalho morto que é prévio a toda ação, determina todas as ações. É, ao mesmo tempo, uma possibilidade, a base de qualquer ação, os meios materiais e mentais concretos para realizá-la e uma constrição, na medida em que condiciona a ação, limita-a, tende a reproduzir-se e a impedir a mudança. Mas não é uma camisa de força, porque os indivíduos e/ou grupos permanentemente confrontam-se com ela, negociam-na, alteram-na. As estruturas do cotidiano são também espaços/palcos de conflitos, podendo ser consensuais ou apenas hegemônicos, ou mesmo claramente conflituosos. (GUARINELLO, 2004, pp. 33-4).

Existe portanto uma tensão entre reprodução/modificação, repetição/inovação, que se dá na própria vida cotidiana. $\mathrm{Na}$ visão do autor, não existem dimensões "acima do cotidiano", como para Agnes Heller: o cotidiano é uma abstração que permite ao

\footnotetext{
75 Segundo o autor, as "estruturas da vida", que não pertencem nem ao mesmo nível ontológico nem se apresentam separadamente, são: a memória, os juízos compartilhados, as interações sociais e a cultura material (GUARINELLO, 2004, pp. 28-31).
} 
observador perceber justamente a tensão mencionada. Certamente, a inovação não é exclusividade dos "grandes homens" (o artista, o cientista, o político etc), mas pode ser observada nas mais diversas práticas. Sem se limitar, como Michel de Certeau, às pequenas práticas, individuais quase sempre, de contestação de ordenamentos, Norberto Guarinello pensa ações tanto individuais quanto coletivas, harmoniosas ou conflituosas, que podem alterar o trabalho morto no diálogo mesmo das possibilidades e condições deste trabalho morto. $\mathrm{O}$ que é a política? $\mathrm{O}$ autor não discute a relação entre inovação e política na vida cotidiana, mas acredito que esta relação pode ser feita, especialmente com a retomada da formulação arendtiana.

\section{Cotidiano e política}

Como dito acima, política para Hannah Arendt é o exercício da faculdade da liberdade, ou seja, da capacidade de começar contra os processos automáticos da vida humana. Ora, tais processos automáticos formam aquilo que foi chamado de "estruturas do cotidiano" (no sentido ontológico): a liberdade se dá na tensão entre repetição/inovação da vida cotidiana, de acordo com a formulação de Norberto Guarinello. A política, pois, seria o exercício consciente desta liberdade de começar na medida em que a ação se volta para a comunidade (como argumenta Agnes Heller): no nosso caso, são políticas as ações voltadas para a polis, cotidianas para os cidadãos. $\mathrm{H}$. Arendt considerava "políticas" somente as ações tomadas por aqueles que possuíam a liberdade plena, ou seja, a política só pode ser feita na polis, "anfiteatro da liberdade" as formulações tanto de Arendt quanto de Heller conlfluem para a afirmação de que a política estava restrita aos cidadãos.

No entanto, as discussões realizadas até aqui podem levar a um caminho diferente. A polis ateniense era trabalho morto: suas instituições (leis, decretos, divisões de poderes e funções, regimes políticos), sua memória (decisões tomadas, revoluções políticas, símbolos, narrativas da oligarquia e da tirania), suas identidades/fronteiras (livre/escravo, homem/mulher, nativo/estrangeiro, rico/pobre, adulto/criança, estrangeiro de passagem/estrangeiro residente, os cruzamentos e mediações entre estas categorias), suas espacialidades (fronteiras territoriais, espaço rural/urbano, espaços cívicos, espaços domésticos, espaços religiosos, espaços vazios), suas temporalidades (ritmo da vida rural/urbana, festivais religiosos, artísticos e esportivos, dia/mês/ano, 
ciclo reprodutivo, calendário de reuniões políticas), seus modos e conteúdos da produção material (trabalho agrícola, escravidão, assalariamento, arrendamento, tributos imperiais, cultura da oliveira, cerâmica), suas representações (literárias, visuais, sonoras, olfativas) etc. Tudo isso se apresentava diante dos habitantes da polis como estrutura já dada, criada em diferentes "espessuras do passado" e com forças de repetição/ordem de diferentes intensidades, de diferentes origens. Entretanto, para ser reproduzido, o trabalho morto da polis deve ser "vivificado" pela ação social, tomada por indivíduos ou grupos, mas que visam a reprodução da polis. Mas o que deve ser (re)produzido? Quem determina? A historiografia tradicionalmente conferiu este poder aos cidadãos; no entanto, não eram apenas os cidadãos que reproduziam a polis, nem regulavam todos os aspectos e momentos desta reprodução. Haviam, pois, "brechas", ou seja, momentos da vivificação do trabalho morto da polis para os quais o acesso não estava restrito aos cidadãos: a logografia, a filosofia, as interações sociais na rua, na casa, que propunham outros usos do espaço, outras identidades, ou seja, outros lugares de existência, heterotopias contra o monopólio cívico.

Mas quais são estes momentos, como se constroem, como se relacionam com a regulação cívica? Aqui, a meu ver, é fundamental pensar o cotidiano ateniense como dimensão específica da vida, tal como desenvolvida por Marta de Andrade na linha da crítica da vida cotidiana lefebvriana. A vida cotidiana ateniense, "a vida comum" (kath'oikian) não como dado, mas como uma construção permanente nas representações e nas práticas. Como demonstrou Marta de Andrade, a "vida comum" ateniense era uma dimensão específica da vida social da polis onde os privilégios cívicos não estavam dados, onde os não-cidadãos contavam com uma liberdade de ações que escapavam à regulação cívica - com isso, foi possível à autora analisar a formulação de estratégias cívicas que procuravam coibir as táticas de habitantes, cidadãos ou não, que por sua vez se voltavam contra tais táticas. Mas o que dizer, repetimos, quando as ações de habitantes, na "vida comum", se voltam justamente para a polis, para sua repetição/inovação?

As duas noções de cotidiano, como categoria ontológica e como dimensão específica da vida não são, necessariamente, excludentes, ainda que partindo de pressupostos e propondo conseqüências diferentes; dependendo do caso, ambas podem fornecer vias de análise confluentes. No caso desta pesquisa, estou argumentando que o "cotidiano-ontológico" permite a formulação da política como "liberdade de começar" 
visando o trabalho morto da polis, ao passo que para se conceber uma política dos nãocidadãos é necessário buscar as brechas no processo de reprodução da polis, brechas que têm na vida comum ateniense, ou seja, num "cotidiano-dimensão específica da vida", um lugar possível. Os lugares da política (outros usos dos espaços, produções de outras identidades e memórias) analisados no capítulo 5 são, conforme tenho argumentado, parte destes momentos nos quais a "brecha" se torna política, nos quais o sujeito da história não mais o grupo excludente dos cidadãos, mas a comunidade includente dos habitantes.

Neste sentido, o que é a polis? Como as instituições da polis se relacionam com a comunidade dos habitantes da polis? Como isso se apresenta para cidadãos e não cidadãos? No capítulo seguinte, procurarei formular algumas possíveis respostas, tão precárias quanto provisórias, a estas questões. 


\section{A questão da polis: cidadãos e habitantes}




\title{
a) A polis como "mediação imediata"
}

\author{
A polis entre o telos e a propriedade: Aristóteles e Marx
}

Após este percurso de crítica historiográfica, de análise da fonte e de teorização, a proposta deste capítulo, certamente sem ambições de fechar questões ou apresentar respostas unívocas, é apresentar um caminho possível de se pensar a polis em Atenas no período clássico (não ousamos aqui falar em "polis grega", muito menos "polis antiga") em marcos que, ao mesmo tempo, ultrapassem os limites da "comunidade de/instituições dos cidadãos" sem diluir a polis em um "guarda-chuva conceitual" que abarcasse uma diversidade infinita de formas sociais, eliminando assim a sua especificidade e potência. Trata-se, aqui, de pensar a produção e a reprodução das instituições da polis (a comunidade política, a polis-institucional) por meio das relações sociais específicas entre os habitantes da polis (a comunidade de habitantes), abordando o caráter "natural" que a polis-institucional assume, de maneiras contraditórias, para cidadãos e não-cidadãos - a análise se voltará para as formas sociais assumidas pelas instituições diante dos grupos sociais definidos por critérios jurídicos, inseridos em espaços de sociabilidade cotidianos, mas indicando, neste "cotidiano", a presença da materialidade institucional da polis dos cidadãos.

Comecemos do princípio: o que é a polis? O início da Política de Aristóteles oferece uma primeira aproximação. Aristóteles define a polis como a comunidade mais importante entre todas, e "como toda comunidade é constituída tendo em vista um certo bem", o bem mais importante é o objetivo (telos) da polis, a saber, a autarquia. Mas qual é a relação da "comunidade mais importante", a polis, com as suas partes, as comunidades menores (homem/mulher, senhor/escravo, aldeia)? Segundo Aristóteles:

A cidade é primeira por natureza, seja com relação à casa, seja com relação a cada um de nós. Pois o todo vem necessariamente antes das partes. Arrancados do todo, os pés e as mãos não existem, a não ser por homologia, como quando dizemos uma mão de pedra. Todas as coisas se definem por sua ação ou seu poder e não mais os tendo, não podemos dizer que são a mesma coisa, mas apenas que têm o mesmo nome. Assim, é evidente que a cidade existe por natureza e que é anterior a cada um. Se ninguém é autárquico, está 
na mesma situação que as partes em relação ao todo. Aquele que não pode viver em comunidade ou que não necessita dela por ser autárquico, é um bicho ou um deus. O impulso em todos para viver em comunidade é, assim, natural, e o primeiro que a constituiu foi causa de grandes bens. [Política, 1253a].

Aqui, a polis é o todo que precede as partes: a exposição aristotélica que começa na família e termina na polis não é uma explicação histórica - não se trata, como pensava Fustel de Coulanges e longa escola, de uma junção de famílias que formariam grupos maiores (frátrias, tribos) até se chegar na polis. A exposição do início da Política é muito mais uma decomposição lógica, que retorna ao seu princípio, o todo que é a polis. Daí a naturalidade da polis, pois o homem, sendo naturalmente político (pois é dotado de fala cuja finalidade - natureza - é indicar o justo e o injusto), só se realiza enquanto tal na polis. O "primeiro que a constituiu" pode ser interpretado como um herói fundador indeterminado - não é herói fundador desta polis específica, mas da polis em geral; esta indeterminação é indicativa do caráter natural-teleológico da polis, cujo surgimento foi necessário para a plena realização do ser humano.

Ora, mas seria a polis a única forma de "realização plena do ser humano"? Hoje, certamente, não concordaríamos com o raciocínio aristotélico: muitas são as formas de organização social, e atribuir a uma delas a primazia do "humano" seria rapidamente considerado etnocentrismo. Mas quais são as razões para que a polis apareça como a forma? Por que a polis é a mais importante das comunidades, o todo que precede as partes?

Alguns anos antes da publicação de $A$ cidade antiga, de Fustel de Coulanges, Karl Marx escrevia alguns manuscritos e rascunhos que dariam origem a sua maior obra, O Capital. Escritos entre 1857-58, os Fundamentos para a crítica da economia política (os chamados Grundrisse) seriam publicados apenas em 1939, em Moscou. Entre estes manuscritos, constavam alguns cadernos que tratavam das Formas que precederam a produção capitalista (as Formen): tratava-se de esboços mais ou menos organizados que ora debatiam com as leituras anarquistas e econômicas da História, ora analisavam algumas formas históricas de propriedade, nas quais, diferentemente da produção capitalista, o trabalhador se relacionava com os meios de produção como proprietário. Destas, três recebem maior atenção: a forma asiática, na qual a comunidade é proprietária absoluta das terras (germe do polêmico "modo de produção asiático"), existente no Egito, na Mesopotâmia, no México, no Peru, entre os celtas e na 
Índia; a forma antiga, na qual a propriedade comunal convive com a propriedade privada individual da terra, existente na Grécia e em Roma; e a forma germânica, na qual a propriedade privada prevalece diante da propriedade comunal, existente entre as comunidades germânicas européias. Interessa-nos, especialmente, a discussão da "forma antiga" e suas indicações para a questão levantada acerca da naturalidade da polis em Aristóteles.

Segundo K. Marx, diferentemente do que ocorre na forma asiática, a relação do indivíduo com a terra na forma antiga não apresenta obstáculos naturais significativos: "as dificuldades encontradas pela comunidade organizada poderão originar-se, apenas, de outras comunidades [...]. A guerra é, portanto, a grande tarefa que a todos compete, o grande trabalho comunal" (MARX, 1977, p. 69). Assim surge a cidade como concentração de moradias, manifestação material da organização bélica da associação de guerreiros. Sendo proprietário privado da terra, o indivíduo deve ser também membro da associação de guerreiros que perpetua tanto a comunidade quanto a propriedade privada. Isto faz com que a comunidade assuma um caráter natural, divino. Eis o raciocínio de Marx:

A comunidade baseia-se, aí, no fato de seus membros serem trabalhadores proprietários, pequenos camponeses que cultivam a terra; mas, igualmente, a independência destes consiste em seu mútuo relacionamento como integrantes da comunidade [...]. Sua relação com sua propriedade privada é ao mesmo tempo uma relação com a terra e com sua existência enquanto membro da comunidade - sua manutenção como membro da comunidade significa a própria manutenção da comunidade e vice-versa, etc. Como a comunidade - que não é aqui, meramente um produto "de fato" da história, mas algo de que os homens têm consciência como tal - tem portanto uma origem, temos a condição prévia da propriedade da terra, vale dizer, da relação entre o sujeito que trabalha com as condições naturais de seu trabalho como algo que lhe pertence. Mas este "pertencer" é mediado por sua existência como membro do Estado, pela existência do Estado - portanto, por uma condição prévia encarada como divina, etc (MARX, 1977, p. 70).

A propriedade na polis é portanto uma "propriedade politicamente constituída", que relaciona intimamente a propriedade privada com o pertencimento à comunidade, criando assim uma manifestação dupla da comunidade para os homens: ela é ao mesmo tempo histórica, tendo uma origem, e divina, como pressuposto. Mas, sendo a 
comunidade não uma coisa em si, mas um "produto de fato da história", ela guarda sua origem: um homem fez a polis, mas ela é a pré-condição para o ser humano - a polis ${ }^{76}$ assume um caráter tanto objetivo, de produto da ação humana, quanto subjetivo (“divino"), de produtora, enquanto pressuposto, desta ação. Uma outra passagem do texto deixa essa imagem mais clara:

A atitude em relação à terra, à terra como propriedade do indivíduo que trabalha, significa que o homem mostra-se, desde o princípio, como algo mais do que a abstração do "indivíduo que trabalha", tendo um modo objetivo de existência na propriedade da terra, que antecede sua atividade e não surge como simples conseqüência dela, sendo tanto uma pré-condição de sua atividade, como é sua própria pele, como são seus órgãos sensoriais, pois toda a pele, e todos os órgãos dos sentidos são, também, desenvolvidos, reproduzidos, etc., no processo da vida, quanto pressupostos deste processo de reprodução. A mediação imediata desta atitude é a existência do indivíduo mais ou menos naturalmente evoluída, mais ou menos historicamente desenvolvida e modificada - como membro de uma comunidade; isto é, sua existência natural como parte de uma tribo, etc. (MARX, 1977, p. 78; grifo do autor).

A propriedade da terra aparece como a pele ou os órgãos sensoriais, produtos e pressupostos da reprodução da vida. A atitude do indivíduo em relação à terra é como a do ser vivo com a sua pele e órgãos sensoriais - uma mediação imediata. Mediação na medida em que é por meio deles que o ser vivo se reproduz; imediatez porque pele e órgãos sensoriais precedem a própria reprodução, não sendo portanto apenas meio, mas fundamento. A forma que essa mediação imediata assume para o indivíduo é o pertencimento à comunidade, que reproduz o lugar de produto/pressuposto: a "existência do indivíduo como membro da comunidade" é percebida como natural, assim como a pele e os órgãos sensoriais o são para o ser vivo. Este pertencimento, que passa pelo reconhecimento tanto subjetivo (o indivíduo se identifica como cidadão) quanto objetivo (o indivíduo é reconhecido pela comunidade como cidadão), se torna o fundamento da vida, assim como sua finalidade principal. Daí a concepção aristotélica, podemos supor, da polis como o todo que precede as partes, cujo telos (sua própria existência, a autarquia) é o mais importante.

\footnotetext{
${ }^{76}$ Entendendo que Marx se refere à polis quando fala em cidade e em Estado.
} 
Em certo sentido, é possível dizer que existe um paralelismo entre as Formen de Marx e o início da Política de Aristóteles: a questão da produção da vida, da formação e finalidade da comunidade etc. O paralelismo é reforçado pela passagem das Formen que aparece em seguida da reflexão sobre a mediação imediata da comunidade. Diz Marx:

Um indivíduo isolado, do mesmo modo que não poderia falar, não poderia ser proprietário do solo. Quando muito poderia viver dele, como uma fonte de suprimentos, como vivem os animais. A relação com a terra, como propriedade, nasce de sua ocupação, pacífica ou violenta, pela tribo, pela comunidade em forma mais ou menos primitiva ou já historicamente desenvolvida. O indivíduo, aqui, nunca pode aparecer no completo isolamento do simples trabalhador livre. (MARX, 1977, p. 78).

Em Marx, o indivíduo isolado, ou seja, que não pertence a uma comunidade e portanto não possui a propriedade da terra, viveria "como vivem os animais", assim como aquele que, para Aristóteles, "não faz parte de qualquer cidade", haverá de ser ou "um bicho, ou um deus" (Política, 1253b). No entanto, apesar do paralelo, não se trata de uma paráfrase: enquanto Aristóteles deriva a existência da polis da natureza, da finalidade do ser humano enquanto ser que fala e portanto pode indicar o justo e injusto, Marx a deriva do regime de propriedade determinado pelas relações estabelecidas nos contatos bélicos entre as comunidades, que geram a associação de cidadãos-guerreiroscamponeses. Esta pode ser uma chave interessante para se pensar as relações entre a polis enquanto instituição (ou simplesmente polis-institucional) e a polis enquanto comunidade de habitantes na sociedade ateniense no período clássico.

\section{Objetivação e subjetivação da polis-intitucional}

Como argumenta imensa historiografia, a polis-institucional fazia a mediação fundamental das relações sociais atenienses. Em primeiro lugar, porque a propriedade fundiária era reconhecida e mantida por meio da polis-institucional: a historiografia é enfática neste aspecto, ressaltando as relações entre terra e cidadania. Em particular, destaca-se o fato de o direito de propriedade de terra e casa (enktesis ges kai oikias) ser exclusivo aos cidadãos, o que era mantido por meio de um conjunto de leis elaboradas 
na instância da polis-institucional ${ }^{77}$ (Austin \& Vidal-Naquet, 1972, pp. 99-102); o arqueólogo italiano G. Nenci afirma, mais radicalmente, que a o espaço físico da polis era um "espaço cadastral", sujeito à gestão do espaço pelas autoridades instituídas, a ponto do proprietário ser visto como um mero possessor do território políade (NENCI, 1979, p. 471). Em segundo lugar, porque a guerra, decidida nas instâncias institucionais (Aseembléia, Conselho), era uma guerra da polis, e não de grupos específicos: ainda que a formação dos batalhões se desse na lógica de tribos e frátrias, são os cidadãos enquanto tais que guerreiam (Garlan, 1991). Em terceiro lugar, porque a escravidão, presente principalmente na mineração, artesanato e trabalhos domésticos (Wood, 1988, pp. 78-80), também era regulada por meio de leis e decretos da polis-institucional: a sua não existência como pessoa portadora de direitos (e consequentemente a série de restrições tomadas por oposição aos direitos dos homens livres), a tortura como procedimento padrão para obtenção do testemunho de escravos, a transformação do escravo liberto em metoikos, a consideração do escravo como propriedade sujeita a transmissão por herança etc (Garlan, 1982; Hansen, 1991, p. 120); inclusive, como aponta a historiografia, um dos principais passos para a construção da democracia ateniense é a lei soloniana que proibia a escravização por dívidas de cidadãos atenienses, que alimenta o debate sobre o verdadeiro pai da democracia, se Sólon ou Clístenes (Finley, 1986; Ste. Croix, 1981; Meier, 1995). Muitos outros aspectos poderiam ser citados, como as relações de parentesco, herança, casamento (Cohen, 1994), as relações com outras poleis e demais organizações (Vlassopoulos, 2007) etc; mas fica que, apesar de existirem diversas dimensões da vida social que escapam da regulação institucional, como, em certa medida, as relações econômicas (Cohen, 2000), o quadro geral em que se produziu materialmente a vida era a polis-institucional.

Este caráter de mediação fundamental das instituições políticas se associa à sua manifestação objetiva: a Assembléia dos cidadãos pré-existe a esta ou aquela reunião, como trabalho morto social fixado e apropriado pela ação social (Guarinello, 2004). As

\footnotetext{
${ }^{77}$ Existe um grande debate sobre o lugar do oikos (termo que congrega a casa, a família e a propriedade; em inglês, household) na sociedade ateniense: alguns autores tendem a pensar o oikos como a instituição central da vida dos atenienses, a partir da qual todas as relações sociais eram estabelecidas; daí se afirmar que Atenas era uma "sociedade de casas" (Cohen, 2000, pp. 32-44). Entretanto, esquece-se que a chamada "centralidade" do oikos pressupunha a polis-institucional, que regulava, entre outras coisas, tanto a propriedade do oikos quanto à sua transmissão por herança.
} 
instituições da polis são assim a exteriorização, a objetivação de práticas sociais passadas, que tendem a limitar, de maneira mais ou menos eficaz, a liberdade da ação humana, em prol da liberação de energias para decisões que pressupõem a organização institucional (Berger\&Luckmann, 2005). Daí a possibilidade da reforma ou mesmo da criação institucional por parte dos cidadãos, que encaram as instituições como coisas, objetos de sua ação: neste quadro se inserem os debates teóricos sobre a polis ideal, a fundação de colônias, os sinecismos ou fragmentações voluntárias.

Mas, sendo a polis um objeto da ação humana que é pressuposto desta ação, ela assume também um caráter subjetivo. Para além da discussão aristotélica da realização da natureza do homem ser efetivada pela polis, está a questão da identidade. É o caso da utilização do termo "a polis dos atenienses", presente nas fontes, e não "a polis de Atenas", como é comum na historiografia (Hansen, 1998). Por um lado, este termo demonstra a indissociabilidade da polis e de seus cidadãos, como que compartilhando entre si, polis e cidadãos, a subjetividade histórica: os cidadãos agem por meio da polis. Por outro lado, o termo "atenienses", como identidade dos cidadãos, é dado pela polisinstitucional. Este papel identificador condiciona tanto a inserção social do indivíduo (sendo cidadão, ele não é nem mulher, nem estrangeiro, nem escravo), quanto a percepção que este tem do mundo (sendo ateniense, marca suas especifidades por comparação, ou às vezes oposição, com outros "gregos" ou "bárbaros"); a polisinstitucional funciona aqui tanto como o meio pelo qual o cidadão, com todas suas prerrogativas político-jurídicas, se diferencia de seus outros, quanto como o próprio sujeito que atribui a identidade cívica ao cidadão.

A questão da identidade cívica assume uma importância fundamental pois, entre outras coisas, o que está em jogo é a subjetividade do ser social. Neste sentido, é interessante retomar aqui algumas das reflexões do filósofo Ruy Fausto (1987) sobre a lógica e o esquema da história de Marx, especialmente na questão da subjetividade histórica. De acordo com o autor, Marx divide a história humana em dois momentos: a pré-história (pré-capitalismo e capitalismo) e história (socialismo). O ser humano somente seria um sujeito verdadeiro no socialismo, ao passo que na sua pré-história, o ser humano tem de "passar" por um predicado: o homem é cidadão romano, o homem é operário. No entanto, a predicação do homem no pré-capitalismo e no capitalismo é diferente, pois, no caso de "o homem é o operário", o predicado "operário" é apenas o objeto do capital subjetivado (é o capital que cria o operário enquanto capital variável, 
submetido à produção de mais-valia - "operário" é um predicado entre predicados); no caso de "o homem é o cidadão romano", o predicado "cidadão romano" é, como afirma o autor, "um sujeito no interior do universo dos predicados" (p. 44).

Este exemplo pode nos ajudar a pensar esta peculiaridade da subjetividade da polis-institucional, pela qual ela é um sujeito, e ao mesmo tempo é percebida como obra humana. Ora, o cidadão se torna um sujeito histórico (adaptando o exemplo de R. Fausto à sociedade ateniense) por meio da identidade cívica ateniense ("o homem é o cidadão ateniense"); a sua predicação (a cidadania) é feita pela polis-institucional: é ela quem concede identidades, que faz tratados, que define os padrões morais etc, ou seja, a polis-institucional, objeto, ganha subjetividade; entretanto, a subjetivação da polisinstitucional funciona no sentido de (re)subjetivar o homem, contradizendo a si mesma: o sentido da "subjetivação" da polis é justamente garantir a liberdade humana como ação subjetiva, que torna a polis novamente um objeto.

Dito de outro modo, a polis-instituição, como objeto criado pelos cidadãos, não se separa e se volta contra seus sujeitos (os cidadãos), como ocorre no capitalismo entre o capital e o trabalho. Entre instituição (polis) e sujeito (cidadão), existe a apropriação. Com ela, a polis-institucional volta a ser um objeto da ação cívica, a política. É nesta contradição que se encontra a política: os cidadãos subjetivam a polis-institucional para se subjetivarem, ou por outro lado, se tornam objeto da ação da polis para poder transformar a própria polis em objeto da ação política.

\section{A primazia da política}

A partir das reflexões precedentes, podemos recolocar a questão da primazia da política na sociedade ateniense enquanto esfera autônoma da vida e em grande medida determinante: o que se costuma chamar de "primazia da política". O próprio Marx, em passagem célebre, aponta esta primazia em resposta a críticas ${ }^{78}$ dirigidas contra seu Para a Crítica da Economia Política, de 1859:

\footnotetext{
${ }^{78}$ Críticas que, inclusive, são repetidas ainda hoje com os mesmos argumentos e incompreensões: ver, p.ex., a discussão de Paul Cartledge em The Greek (2002, pp. 105-6).
} 
[Um jornal teuto-americano] dizia, minha opinião, que determinado sistema de produção e as relações de produção a ele correspondentes, de cada vez, em suma, "a estrutura econômica da sociedade seria a base real sobre a qual levanta-se uma superestrutura jurídica e política, e à qual corresponderiam determinadas formas sociais de consciência", que "o modo de produção da vida material condicionaria o processo da vida social, política e intelectual em geral” tudo isto estaria até mesmo certo para o mundo atual, dominado pelos interesses materiais, mas não para a Idade Média, dominada pelo catolicismo, nem para Atenas e Roma, onde dominava a política. [...] Deve ser claro que a Idade Média não podia viver do capitalismo nem o mundo antigo da política. A forma e o modo como eles ganhavam a vida explica, ao contrário, por que lá a política, aqui o catolicismo, desempenhava o papel principal. (MARX, 1988, p. 77, n.33).

Aqui fica claro que não se trata, para Marx, de estabelecer relações mecânicas entre a economia e a política, ou a economia e a religião ${ }^{79}$, até por que a própria constituição da economia enquanto esfera autônoma (fetichizada, pois) é um fenômeno histórico específico do capitalismo (KURZ, 1994). Mas quais eram, então, as bases materiais (o "ganhar a vida") que permitiam, na polis de Atenas, que a política se apresentasse como dominante?

Pode-se pensar uma solução para este problema a partir da idéia das mediações, realizadas pela polis-institucional, na produção material da vida da sociedade ateniense, do ponto de vista da oposição entre apropriação e alienação das instituições políticas. Na democracia, os cidadãos (homens, adultos, livres, filhos de pai, e, por vezes, também de mãe atenienses) se apropriam das instituições por meio da prática política institucional: a relação dos cidadãos com a polis não é de alteridade, mas de identidade - a polis é dos atenienses, por isso a polis é os atenienses (HANSEN, 1991, p. 59). Na oligarquia, diferentemente, somente uma parte do corpo cívico realiza esta apropriação institucional, enquanto que os cidadãos "passivos" percebem as instituições como algo fora de sua prática, como um outro, numa relação de alienação: os oligarcas usam as instituições para manter privilégios, para se apropriar das terras, para oprimir os pobres etc. Mas isto significa dizer que a política não se restringe aos seus marcos institucionais, mas os ultrapassa, podendo inclusive ser a ação que destrói e recria as instituições: é o caso, portanto, de retomar o sentido da palavra "política" como "prática da liberdade" (Arendt, 2005).

\footnotetext{
${ }^{79}$ Para um tratamento crítico do tema da "base e superestrutura", ver Wood (1995).
} 
Mas qual é o lugar da política, ultrapassados os limites institucionais? É possível falar em política dos habitantes, e mais, ação política dos não-cidadãos? A historiografia da polis construiu importantes debates no que diz respeito às lutas políticas atenienses, mas não ultrapassou os marcos do corpo cívico. Assim, as análises que explicavam a excepcional estabilidade de Atenas no período clássico por meio da compensação democrática entre cidadãos ricos e pobres, teve que pressupor uma massa amorfa de não-cidadãos que não se importavam com nem participavam nas lutas políticas. No sentido de encaminhar uma proposta para se pensar a política dos não-cidadãos, como uma política cotidiana dos habitantes, tomemos o caso dos metecos atenienses, lidos por meio da chave apropriação/alienação das instituições objetivadas.

\section{b) Dialética e crise da polis}

\section{Os termos da contradição}

O historiador, filólogo e arqueólogo italiano Giuseppe Nenci, em um pequeno texto do final da década de 1970 sobre a questão da espacialidade da cidade grega (espaços territoriais e metafóricos; políticos, religiosos, cadastrais, estratégicos etc), discute o conceito de espaço cívico se contrapondo às posições de P. Lévêque e P. Vidal-Naquet, que associam o espaço cívico das reformas clistenianas ao espaço habitado da polis. Segundo Nenci:

Na realidade, quando pela cidade grega [città greca] da idade histórica nós falamos de "espaço cívico" e nos referimos à repartições como aquelas da reforma clisteniana, arriscamos esquecer um fato, que no mundo grego é de enorme relevância, que é que o "espaço cívico" diz respeito aos cidadãos e à sua propriedade fundiária, mas que a cidade grega é feita, como toda cidade, por habitantes e não somente por cidadãos pleno iure. Em outros termos, o problema do espaço cívico na cidade grega é expressão de uma ideologia do espaço que é fruto precípuo das classes dirigentes gregas (sejam essas

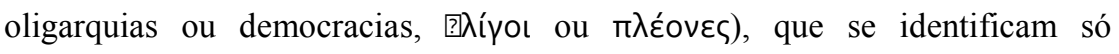
parcialmente com os habitantes (pense-se, a prescindir dos membros do núcleo familiar privados de direitos políticos, como jovens e mulheres, nos escravos, 
libertos, metecos e forasteiros de passagem). E se a cidade é aparentemente um conjunto coerente de cidadãos teoricamente iguais, de fato uma cidade, e sobretudo uma grande cidade, é um conjunto incoerente de habitantes de fato nada iguais: o "espaço cívico", repito, é a relação que existe entre "espaço território" e o modo de ser dos cidadãos. (NENCI, 1979, p. 462-3).

A contradição entre coerência/incoerência, ou entre cidadãos/habitantes, é o que gera, para o autor, uma série de medidas do corpo cívico para esquadrinhar e regular o "espaço território", ou seja, o espaço habitado da polis, de modo a anular a incoerência e a heterogeneidade do espaço habitado ${ }^{80}$. Desse modo, o espaço apresenta contradições próprias, produzidas por tensões tensão tanto no nível das práticas (regulação/uso), quanto das representações (discursos/contra-discursos). No entanto, como aponta o autor, essas contradições são socialmente produzidas, a partir do modo específico pelo qual a propriedade fundiária se relaciona com a organização social: cidadãos são os proprietários da terra, o que lhes confere o direito supremo sobre o espaço. Mas como se relacionam os habitantes com esta dialética fundante da polis? Tomemos o caso dos metecos.

A historiografia, tanto a geral da polis quanto a específica dos metecos atenienses, é enfática: “os metecos atenienses estão excluídos da democracia”. Disto, que se tornou um senso comum, segue uma lista de restrições: não podem participar da Assembléia, não podem se dirigir diretamente ao conselho, não podem ter propriedade de terra ou casa, pagavam mais impostos que os cidadãos, sua vida valia menos que a vida de um cidadão ${ }^{81}$ etc (Hansen, 1991, pp. 116-24). Além disso, o meteco é definido pela negação: não é cidadão nem escravo. Desta maneira, constrói-se a imagem do meteco como o Outro interno à polis: residente no mesmo espaço, mas estrangeiro e estranho ao corpo cívico. Por outro lado, existe um outro senso comum na historiografia, segundo o qual "a cidade tem necessidade dos metecos, por causa de

${ }^{80}$ A partir disso o autor desenvolve a análise sobre as diferentes espacialidades da polis, em particular a presença dos "terrenos vazios intramuros", pertencentes à polis e reservados para construção de edifícios, que leva o autor a discutir a relação entre propriedade/posse da terra e ideologia cívico, formulando a teoria do "espaço cadastral”, que seria o pressuposto para a gestão e intervenção cpivica no espaço habitado (NENCI, 1979, pp. 468-73).

${ }^{81} \mathrm{O}$ suspeito de assassinato premeditado de um cidadão era julgado no Areópago e corria o risco da pena de morte; o suspeito de assassinato de um meteco era julgado no Palladion, tribunal de "crimes de sangue menores”, como o assassinato não-proposital, e a pena máxima seria o exílio. Cf. TODD, 1993, p. 169). 
todos os serviços econômicos que eles lhes prestam (manufatura, comércio), por causa dos rendimentos que fornecem ao Estado, sem nada lhe custarem, e devido à sua utilidade no exército e na marinha" (Austin \& Vidal-Naquet, 1972, p. 104). De qualquer modo, o meteco aparece enquanto objeto: é útil na guerra, é útil economicamente, é excluído da democracia etc. Estes sensos comuns, inclusive, se fundamentam nas fontes: por exemplo, (o meteco) Aristóteles, reduz a existência dos metecos às atividades hoje denominadas econômicas, retirando-lhes qualquer das virtudes de um cidadão (Ética a Eudemo, 1233a28-30).

No entanto, mesmo dentro deste esquema, considerado por alguns autores como a ideologia cívica a respeito dos metecos (Whitehead, 1977; Baslez, 1984), surge uma questão: até que ponto os metecos estão excluídos da polis, na medida em que esta necessita deles, e, por outro lado, em que medida os metecos estão incluídos na polis, na medida que estão fora do campo institucional da polis? A mesma questão é exposta por M. Austin e P. Vidal-Naquet: "os metecos são indispensáveis à vida econômica da cidade; e todavia, não fazem verdadeiramente parte da cidade, pois são excluídos de todos os direitos políticos" (1972, p. 104). Os autores não desenvolvem a questão (até porque seguem a forma de exposição consagrada: algumas páginas para os cidadãos, menos para os metecos, menos ainda para os escravos, e nenhuma para as mulheres), mas podemos questionar aqui:o que é, afinal, participar da polis? Ou: qual é a relação entre a participação econômica e a não-participação política dos metecos na polis dos cidadãos? E, mais além: como os metecos participam da polis dos habitantes?

Aceitando a definição do meteco como objeto (econômico, militar), notamos que a polis dos cidadãos, para existir materialmente, necessita da ação dos metecos, que estão definidos por oposição aos cidadãos (ter direitos / não ter direitos), enquanto que a ação subjetiva dos metecos nega a si mesma na medida em que produz um objeto que não lhes pertence, e que se volta contra eles: a polis dos cidadãos. A polis dos cidadãos precisa, portanto, incluir em si a sua negação (a ação dos não-cidadãos, metecos) para sua realização, e a ação dos metecos precisa, também, incluir dentro de si a sua negação (a polis dos cidadãos) para sua realização (posto que só são metecos, enquanto identidade, por oposição aos cidadãos). Esta contradição da polis é a condição de sua própria existência, e se funda, essencialmente, na objetivação do meteco enquanto elemento útil para si; deste modo, pode-se pensar um conceito de crise da polis, crise imanente esta, se pensarmos na formulação de R. Fausto acima citada: “o homem é o 
meteco ateniense" - "meteco ateniense" também é um "sujeito no interior do universo dos predicados". A crise se manifesta na medida em que o ocultamento implícito na expressão "meteco ateniense" - os metecos produzem a polis mas não são a polis - se apresenta enquanto contradição, abrindo o caminho para a apropriação política da polis por vias não-institucionais.

Mas haveriam formas não-institucionais de apropriação da polis, ou seja, de política? Como foi argumentado nos capítulos 5 e 6, os discursos de Lísias permitem o acesso a práticas políticas de não-cidadãos, tendo em vista uma definição de política como liberdade cotidiana de começar, contra os automatismos da vida; foram analisados também alguns lugares dessa liberdade, como outros usos dos espaços da polis na "vida comum" e a construção de outras memórias e da identidades. Estas seriam "brechas" da polis-institucional, pelas quais os não-cidadãos, produtores da polis, se encontrariam numa relação não mais objetiva (identidades definidas pela polis, funções, lugares etc), mas subjetiva; ou seja, as brechas seriam momentos nos quais os não-cidadãos criticariam (por representações e práticas) o caráter "fetichista" da polis e assumiriam uma subjetividade política ao lado e/ou contra o corpo cívico. Gostaria de argumentar neste sentido, finalmente, utilizando quatro discursos do Corpus: sobre escravos, Por Cálias (lys.5) e Contra Pancleão (lys.23); sobre metecos, Contra os mercadores de trigo (lys.22) e, mais detidamente, Contra Eratóstenes (lys.12).

\section{Escravidão e brecha jurídica: Cálias e Pancleão}

O discurso Por Cálias nos chegou como um fragmento de apenas 5 parágrafos: duas páginas do manuscrito Palatinus foram arrancadas, levando consigo o final do discurso Por Cálias e o início do seguinte, Contra Andócides. Além disso, não há nenhuma informação sobre datação. Sabe-se que o discurso é parte da defesa de um certo Cálias, meteco já de idade avançada, contra a acusação de crime religioso (que não é especificado); é possível que Cálias não seja o único acusado, devido ao uso de alguns plurais no texto; os acusadores são os escravos de Cálias, os quais, caso obtivessem a acusação, receberiam a liberdade; o discurso é dirigido a uma corte popular comum, e não ao Areópago, normalmente a corte adequada a assuntos religiosos; o orador é um dos amigos de Cálias que tomam a palavra em sua defesa, pois é provável que, sendo meteco, Cálias não teria direito de se defender. 
O discurso, como comumente ocorre no Corpus, utiliza a construção do ethos, de Cálias e dos acusadores, como argumento: por um lado, Cálias sempre manteve boas relações com todos, nunca se envolveu em qualquer litígio, nunca foi reprovado por nenhuma conduta durante sua longa vida, e além disso fez muitas boas ações (não mencionadas) pela polis - por tudo isso, é digno que Cálias fosse recompensado pela polis, e não posto em perigo; seus acusadores, por outro lado, são criminosos e mentirosos que esperam, com a vitória na acusação, a conquista da liberdade - o júri deveria desconfiar dos acusadores que acusam tendo em vista o próprio lucro. Esta argumentação, como foi dito, é bastante comum no Corpus. Entretando, um argumento apresenta questões bastante interessantes. Diz o orador:

Parece-me que esta disputa não é de interesse privado ([ॄఠıv), mas de interesse público (KoเV?v) para todos na polis; pois não são somente os acusados que têm escravos, mas todos os outros também os têm; vendo a sorte dos acusados, os escravos visarão não mais realizar bons serviços aos senhores como meio de se tornarem livres, mas sim denuncia-los por mentiras... [início da lacuna no manuscrito] (5.5).

Como fica claro, existe uma possibilidade institucional para a libertação dos escravos: a condenação do senhor por meio da denúncia. Se no início do discurso Cálias foi pintado como o "bom meteco", nesta passagem final ele é colocado dentro de um grupo mais amplo, envolvendo cidadãos e metecos: esta identificação se dá pelo denominador comum, a posse de escravos. E diante do ocorrido com Cálias, todos os senhores de escravos (cidadãos ou não, os membros do júri ou não) devem se preocupar com o caso: a decisão do júri pode repercutir na polis de um modo destrutivo, na forma de uma onda de denúncias de escravos que visam a libertação. Ocorreria uma inversão: se normalmente existem senhores e escravos, e a libertação vem pelos bons serviços prestador pelo escravo ao seu senhor, a condenação de Cálias e sua repercussão faria com que o sistema jurídico ateniense se voltasse contra a própria polis, rompendo a "normalidade escravista" por meio dessa brecha institucional.

A amplificação do julgamento privado de Cálias e seus escravos em uma questão coletiva, a prática da denúncia de escravos para sua libertação ganha um contorno político: o júri deve absolver o condenado para coibir, do início, uma ação coletiva dos escravos utilizando as brechas institucionais do sistema jurídico ateniense. 
O meteco é a polis, os escravos são a escravidão: a metonímia coloca em questão a própria ordem social ateniense, contra a possível inversão seja privada, seja pública da normalidade escravista. Política aqui é tanto a ação escrava, na medida em que visam, potencialmente, a ordem social da polis, quanto a problematização jurídica desta ação.

O discurso Contra Pancleão traz uma das mais interessantes narrativas do Corpus. Um cidadão ateniense, o orador, sofria continuamente injustiças (não especificadas) de um certo Pancleão; foi até a oficina onde o suposto criminoso trabalhava, dizer que o iria citar diante do Polemarco, magistrado responsável pelas acusações dirigidas a metecos. Pancleão afirmou que não poderia ser julgado pelo Polemarco, posto que era um plateu, e portanto cidadão ateniense ${ }^{82}$. O orador foi aconselhado a citar Pancleão diante de um juiz tribal ${ }^{83}$, e por isso perguntou a qual demos Pancleão pertencia, ao que foi respondido: "Deceléia".

$\mathrm{O}$ orador foi a uma barbearia onde normalmente se reuniam os habitantes de Deceléia: conversou com alguns, e ninguém conhecia qualquer Pancleão; ao mesmo tempo, o orador descobriu que já havia processos contra Pancleão diante do Polemarco. Em um deles, Pancleão declinou do seu direito de defender seu status de cidadão (o que invalidaria o processo executado diante do Polemarco), preferindo perder o processo e pagar uma determinada soma ao acusador; após a derrota, ele teria abandonado Atenas e vivido por um bom tempo como meteco em Tebas, fato que, para o orador, comprova que ele de fato não era um plateu: os tebanos eram os responsáveis pela destruição de Platéia, portanto Tebas seria a última polis a ser escolhida por um plateu como local de residência.

Mesmo com essas informações, o orador continuou sua pesquisa: foi ao encontro do mais velho dos plateus em Atenas, que, também sem conhecer Pancleão, aconselhou o orador a ir ao mercado de queijos frescos, onde, mensalmente, a maioria dos plateus se encontravam - ali poderia tirar suas dúvidas. No mercado de queijos, novamente,

\footnotetext{
82 Os habitantes de Plateía, tradicionalmente aliados de Atenas, receberam cidadania ateniense plena no início da Guerra do Peloponeso, quando sua polis foi destruída por Tebas (TODD, 1993, p. 167).

${ }^{83}$ Quarenta juízos eram eleitos anualmente para se encarregar do início dos procedimentos para casos privados (dikai) envolvendo a acusação a membros de determinada tribo: como Atenas era dividida em dez tribos, dentro das quais se alojavam as dezenas de demos, havia quatro juízes para cada tribo. (TODD, 1993, pp. 168).
} 
ninguém conhecia um plateu chamado Pancleão; no entanto, um cidadão (provavelmente Nicomenes) afirmou que um escravo seu, com esse nome, havia fugido. Poucos dias depois, o orador viu Nicomenes tentando prender Pancleão, ao que era impedido pelos companheiros deste, que não só garantiram que ele era cidadão, como afirmaram que trariam um irmão de Pancleão, no dia seguinte, para comprovar seu status. Nenhum irmão apareceu, mas, pelo contrário, uma mulher (não nomeada) surgiu dizendo que Pancleão era seu escravo, e entrou em disputa com Nicomenes. Pancleão, ajudado por seus companheiros, fugiu de ambos supostos senhores.

Como o orador prosseguiu com sua ação diante do Polemarco, Pancleão abriu contra ele uma antigraphe, ou seja, uma ação que visa a anular uma ação precedente, especialmente por esta utilizar um procedimento inadequado: no caso, acusar um cidadão diante do Polemarco. O discurso Contra Pancleão é provavelmente a defesa desta antigraphe, pois o orador procura, com a narrativa, provar que Pancleão não era nem plateu nem cidadão ateniense e que portanto o processo poderia ser conduzido diante do Polemarco. Nicomacus, um dos que alegavam ser senhores do escravo Pancleão, estava presente no tribunal (ele é uma das testemunhas), o que significa que, caso ficasse provado que Pancleão não era um plateu, ele imediatamente seria capturado pelo seu suposto senhor.

O discurso é riquíssimo em possibilidades de análise, mas aqui será abordada apenas, e brevemente, a questão da polis e da política dos não-cidadãos. Ora, no discurso Contra Pancleão aparece mais uma brecha institucional do direito ateniense: ao mesmo tempo em que o sistema de status era fundamental para as regras procedurais, não havia um sistema organizado de listagem indicando quais indivíduos fazem parte de quais grupos $^{84}$. O orador deve assumir o lugar de investigador, contando apenas com a memória oral dos habitantes (TODD, 2000, p. 246), criando assim um tempo precioso para o acusado: no caso de um escravo fugido, existe a possibilidade de mudar-se para um demos onde os habitantes não tenham condições de determinar se ele é ou não plateu, ou mesmo de migrar para outra polis e se estabelecer como meteco. A identidade de "plateu" é extremamente tática em Atenas: aquele que alega ser plateu conta com a

\footnotetext{
${ }^{84}$ Um desenvolvimento interessante da idéia de precariedade e acaísmo institucional ateniense clássico, ainda que menospreze a efetividade das instituições e por isso se enfraquece, foi realizado por Philip B. Manville (1994), que usa estes dados para construir um paradigma "pré/pós-moderno" de análise histórica da polis.
} 
prerrogativa de não ser conhecido pelos atenienses, e assim pode participar dos direitos cívicos. Ocorre, portanto, uma confluência de fatores históricos (a concessão de cidadania aos plateus) e institucionais (a ausência de controles efetivos da polis sobre as identidades fronteiriças) que torna plausível que um escravo fugido de dois senhores diferentes fosse considerado de fato e de direito um cidadão.

Aparentemente trata-se de um caso individual: Pancleão e sua trajetória. No entanto, a plausibilidade da narrativa, fundamental na retórica judiciária, indica que havia essa possibilidade como realidade social. Além disso, Pancleão dialoga com as instituições propriamente cívicas: o Polemarco, as tribos, os juízes tribais, o demos, os procedimentos jurídicos - a polis é transformada em instrumento por um (suposto) nãocidadão, instrumento de acesso não apenas à liberdade individual (contra a escravidão), mas à participação na liberdade política "plena" (os direitos cívicos). É a polis que está em questão na trajetória de Pancleão, assim como na trajetória do orador em sua investigação. A incerteza, as idas e vindas do cidadão diante de Pancleão demonstram um momento na reprodução sócio-espacial e institucional da polis nas quais as prerrogativas dos cidadãos são questionadas radicalmente, quando as fronteiras civicamente construídas, por meio das instituições civicamente controladas, são embaralhadas no movimento mais amplo da totalidade social. É nesse momento que as contradições da polis se agudizam: a dialética se torna crise.

\section{Metoikia e brecha jurídica: os mercadores de trigo}

Como foi bastante enfatizado pela historiografia, a polis de Atenas dependia em grande medida da importação de trigo para abastecer sua população, daí uma série de medidas que visavam o controle institucional-cívico deste comércio (GARNSEY, 1988). O discurso Contra os mercadores de trigo põe em evidência a preocupação institucional com a conduta dos agentes desta importação, em particular dos metecos: um grupo de metecos que comercializavam o trigo importado no varejo é acusado de manipular o preço do trigo por meio da compra de uma cota maior que o permitido ${ }^{85}$. O

\footnotetext{
${ }^{85}$ Esta é uma possível interpretação dos termos sunoneisthai e sumpriasthai, como realizada por R. Seager (1966); uma outra possibilidade, desenvolvida por T. Figueira (1986), é que trata-se da formação de um cartel, o prefixo “sun-” se referindo não à quantidade de trigo, mas aos próprios mercadores.
} 
discurso é pronunciado por um membro do Conselho num tribunal comum. Não se sabe a data precisa do processo, mas sabe-se que ocorreu num período de crise alimentar: Todd (2000, p. 239) acredita que ocorreu na década de 380 a. C., após o fracasso da reconstrução do império ateniense.

O discurso Contra os mercadores de trigo apresenta uma espécie de interrogatório, no qual de um dos mercadores responde às questões do orador. Segue a passagem:

- Diga-me, você é um meteco?

- Sim.

- Residindo aqui como meteco, seu objetivo é obedecer às leis ou fazer o que desejar?

- Obedecer.

- Você concorda que merece a pena de morte, caso viole as leis para as quais a pena é a morte?

- Eu concordo.

- Diga-me se você reconhece que comprou junto mais grãos do que as 50 medidas permitidas pela lei.

- Eu o fiz sob as ordens dos magistrados. (22.5).

Começando pela determinação do "acordo retórico", qual seja, de que os metecos devem obedecer às leis e seus procedimentos, o orador procura fazer com que o próprio acusado conclua a necessidade da pena de morte. A saída do acusado é transferir a culpa, de si para o magistrado. Aqui não serão discutidas as implicações jurídicas deste interrogatório, desenvolvidas por S. Todd (1993, pp. 316-20); no entanto, um tema parece ter escapado àqueles que analisaram este discurso: o tema da objetividade/subjetividade.

A acusação se fundamenta na alegação de que os metecos não respeitaram a lei, ou seja, que agiram por sua livre iniciativa tornando-se desobedientes - tornaram-se sujeitos, contra a objetividade posta pela polis-institucional por meio das leis. Daí a estratégia de defesa: o meteco não nega o crime, mas nega a subjetividade - ele não agiu por si, mas sob ordens dos magistrados. Assim, o crime é da responsabilidade da própria polis, na medida em que os magistrados são cidadãos instituídos como sujeitos da polis-institucional: em todo o tempo, o meteco obedeceu à polis, na forma de suas leis e de seus magistrados - o meteco foi um objeto. O resto do discurso procurará 
invalidar a alegação do acusado, seja trazendo os magistrados como testemunhas, seja argumentando pela inverossimilhança da situação.

Entretanto, pode-se fazer uma leitura inversa do interrogatório: o meteco argumenta que é um objeto, mas, ao fazê-lo, se torna um sujeito. As instituições da polis, monopolizadas pelos cidadãos, se tornam uma arma de defesa: o meteco utiliza as próprias brechas do regime institucional ateniense, a saber, a possibilidade de um magistrado contrapor-se a uma lei, para assim, reafirmando a objetividade de sua condição (obediente à leis e magistrados), legitimar seu ato criminoso. A polis não pode condená-lo já que é a própria polis a culpada: assim o meteco argumenta, tornando-se, pois, sujeito contraditoriamente.

Não se sabe o resultado do julgamento, mas o próprio discurso dá indicações de que havia um sentimento generalizado de aversão aos acusados: o orador, como informa no início do discurso, foi contra a execução dos acusados sem um julgamento, como poderia ter sido feito pelo Conselho - por isso ele se tornou acusador, para que não fosse tomado como um defensor dos mercadores. De qualquer maneira, condenados ou não, a estratégia de defesa tal como apresentada no interrogatório de acusação demonstra que, nos quadros da necessidade do trabalhos dos metecos para a importação e comércio de trigo, poderiam surgir brechas nas quais a aparente objetividade da cndição meteca se transforma em subjetividade - novamente, como no caso de Contra Pancleão, a dialética se torna crise. O desenvolvimento da idéia de crise da polis será feito por meio da análise mais detida do discurso central no Corpus Lysiacum, o único sobre o qual (quase) não pairam dúvidas acerca da autoria, e no qual o próprio Lísias está totalmente implicado: discurso 12, Contra Eratóstenes.

\section{c) A democracia pelo avesso: cisão e porosidade em Contra Eratóstenes (lys.12)}

Não é começar a acusação que me parece difícil, senhores do júri, mas conduzi-la a um término. Tão grandes e muitos são seus crimes, que mentindo eu não os acusaria de crimes tão terríveis, e desejando dizer a verdade não conseguiria dizer tudo: necessariamente ou o acusador desistiria por exaustão, ou o tempo se esgotaria. Parece-me ocorrer o oposto do que tradicionalmente ocorre: se antes o acusador 
necessitava expor sua inimizade pelos acusados, agora é preciso questionar os acusados sobre sua inimizade pela cidade, contra a qual eles tiveram a coragem de cometer tais crimes. Faço estas reflexões, entretanto, não por me faltarem motivos

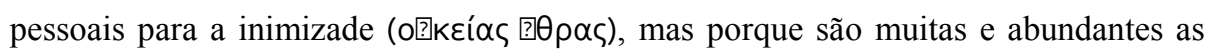

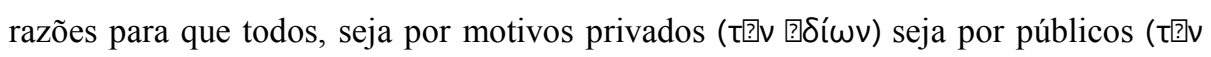

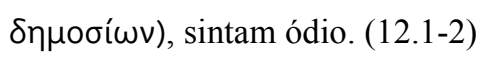

É pela amplificação que o orador abre o discurso Contra Eratóstenes, que era um dos Trinta, pronunciado pelo próprio Lísias: tão grandes e graves são os crimes dos acusados, que se encontram além das possibilidades oratórias: os limites da capacidade de mentir do orador, suas limitações físicas e a limitação do tempo de fala impedem que os crimes dos acusados sejam apreendidos pelo discurso. Estes três limites (intelectual, corporal e institucional) marcam a fronteira da aplicação da justiça de acordo com as regras do direito ateniense - é por meio deste cleuasmo ampliado, ou seja, menosprezo fictício não somente de si, mas do sistema jurídico inteiro, que o orador amplifica a gravidade dos crimes. Mas quais crimes são esses, e quais criminosos, que se localizam para além da justiça instituída?

Não se trata de um crime somente contra a pessoa do acusador, mas também contra a cidade. Daí a proposição de que os acusados expliquem sua inimizade contra a cidade, invertendo a prática habitual de o acusador expor suas queixas contra o acusado - proposição puramente retórica: o discurso seguirá o modo habitual. De qualquer modo, este movimento introduz um dado fundamental: não apenas o orador, mas toda a cidade foi prejudicada pelo acusado - o privado e o público se unem no ódio ao acusado, que é quem deve se explicar. Se a acusação, pelo discurso, assume a forma de uma fala individual, seu conteúdo se apresenta como expressão do sentimento de todos, seja como indivíduos (idios), seja como coletividade (demos): o orador fala em nome de si mesmo e em nome de todos. Nesta dialética entre forma e conteúdo, o júri é posicionado como vítima: mais do que uma apóstrofe, na qual o orador finge falar com um auditório diferente do seu, aqui se trata da proposição de uma subjetividade específica para o auditório, a de vítimas nos níveis público e privado. O júri, portanto, não se coloca como terceira parte, neutra; a objetividade lhe é negada, e é nesta subjetivação, como vítimas, que opera o discurso.

Mas como se vingar das ofensas do acusado contra todos, se o discurso não é capaz de apreender a magnitude de seus crimes? Ora, se a subjetivação do júri como 
vítima der certo, o orador e seu discurso, limitados, ganham um aliado fundamental para a vitória: o auditório. Ao mesmo tempo júri (com o poder de decidir, pelo simples voto e sem discussão prévia, a culpa e a pena do acusado) e parte ofendida (que procura sua vingança), o auditório conta com a própria memória - individual e coletiva, privada e pública - para fazer com que o sistema jurídico ateniense, limitado, consiga realizar a justiça que o orador e seu discurso, sozinhos, não seriam capazes de fazer. Estratégia da identidade, estratégia da memória: é pela posição do sujeito-vítima sobre o auditório e pela rememoração das ofensas sofridas pelos indivíduos e pela coletividade que o discurso começa sua trajetória.

O discurso Contra Eratóstenes, ou "lys.12" na numeração tradicional do Corpus, é o mais famoso e o único do qual se tem certeza que foi escrito pelo próprio Lísias; acusa Eratóstenes de ser o responsável pela morte de seu irmão, Polemarco, entre outros crimes que o acusado teria cometido ao fazer parte do regime dos Trinta. Segundo o discurso, o regime dos Trinta decidiu prender e confiscar a propriedade dos metecos (estrangeiros residentes em Atenas) de modo a suprir as necessidades do regime, assim como para o enriquecimento privado de cada um dos oligarcas; Polemarco e Lísias estavam entre os mais ricos metecos de Atenas, e como tais foram perseguidos pelos Trinta: Lísias conseguiu fugir de Atenas e partiu para a vizinha Mégara, enquanto Polemarco foi preso e executado; a propriedade de ambos foi confiscada, o que incluía uma fábrica de escudos com 120 escravos e uma enorme quantidade de dinheiro, jóias e outros bens (somando cerca de 70 talentos).

Em primeira pessoa, o discurso contém informações relevantes não apenas para a biografia de Lísias, como também para a história dos regimes oligárquicos em Atenas no final do século V a. C., em especial o segundo, o regime dos Trinta. Além disso, o discurso 12 é geralmente citado como exemplo da excelência retórica de Lísias, em particular a clareza da narrativa e a habilidade na caracterização dos personagens. Mas sua importância e fama não o retiram por inteiro da incerteza que reina no Corpus: não se sabe ao certo qual procedimento jurídico que lhe serve de moldura, se uma prestação de contas (euthunai) ou uma acusação por homicídio (dike phonou), e mesmo não há 
garantia de que ele foi realmente pronunciado em tribunal ou somente circulou como panfleto.

O presente texto é uma análise do discurso Contra Eratóstenes a partir de duas questões: a construção das identidades de cidadãos e metecos e o lugar da memória. A partir do tratamento destas questões, serão abordadas suas conseqüências para a história da participação dos metecos na restauração da democracia ateniense de 403 a. C., e as derivações desta participação para a discussão do conceito de polis. Para isso, o texto está dividido em cinco partes: 1) a posição do discurso no contexto da restauração e da anistia de 403/2 a. C., 2) a discussão sobre a estruturação geral do discurso, 3) a análise de trechos sobre o tema da identidade e 4) da memória; e finalmente 5) a discussão de algumas conclusões possíveis para o conceito histórico e historiográfico de polis.

O discurso foi produzido durante ou logo em seguida ao processo que se convencionou chamar de "restauração democrática", ocorrida em 403 a. C., contra o regime oligárquico dos $\operatorname{Trinta}^{86}$. Qual o lugar do discurso Contra Eratóstenes neste contexto? Como determinavam os termos da reconciliação, antigos membros dos Trinta, se fossem aprovados em suas prestações de contas, poderiam ficar em Atenas e seriam protegidos pela anistia. É possível que Eratóstenes tenha escolhido ficar na cidade, e o discurso de Lísias em questão teria sido escrito como parte da acusação de sua prestação de contas. Outra possibilidade é que teria sido pronunciado como acusação de uma dike phonou, procedimento em caso de homicídio, mas contra esta hipótese estão os próprios termos da anistia: se Eratóstenes, permanecendo em Atenas, havia passado pela prestação de contas, não poderia ser julgado por ações passadas. Outra possibilidade tem sido aventada: S. Todd tende a acreditar que se trata de um panfleto, escrito por Lísias, expondo o que ele teria dito caso participasse do julgamento ${ }^{87}$ (aspecto sobre o

\footnotetext{
${ }^{86} \mathrm{~V}$. Introdução.

87 A historiografia não tem respostas seguras para algumas questões centrais: a) se Lísias obteve a cidadania, mesmo que por um curto período, e então pode acusar diretamente Eratóstenes; b) se, como meteco, era possível pronunciar um discurso sem mediação de um patrono (a historiografia mais recente tende a questionar e nuançar tal proibição, tradicionalmente considerada uma das marcas do estatuto de meteco). V. Todd (1993, pp. 194-9).
} 
qual a historiografia não tem respostas seguras). De qualquer modo, o discurso 12 está inserido num contexto de questionamento não somente do modo como a restauração será realizada, mas de rediscussão da própria democracia e sua relação com a memória. Mas, antes de passarmos ao tratamento das questões da identidade, da memória, tal como enunciadas acima, seguem algumas observações sobre a estruturação das partes do discurso.

O discurso contém as quatro partes tradicionais da retórica (proêmio, narrativa, prova e exórdio), mas não segue uma compartimentação rígida: assim, intercalam-se as narrativas com interpretações e discussão de argumentos. Estão incluídos também dois momentos para testemunho (confirmando a narrativa) e uma inquirição ao acusado (direcionando a argumentação). Dessa maneira, o discurso pode ser dividido em:

\section{1-3. Proêmio}

4-19. Narrativa (conduta da família de Lísias em Atenas; perseguições dos Trinta; confisco da propriedade; exílio de Lísias; execução de Polemarco).

20-24. Provas (injustiça da perseguição; comparação da conduta das vítimas como metecos e dos perseguidores como cidadãos).

25-34. Inquirição do acusado e refutação de suas afirmações (sobre a disposição do acusado ao prender Polemarco).

34-41. Provas (condenação exemplar aos cidadãos e aos estrangeiros; antecipação e refutação dos argumentos de boa conduta do acusado e apoiadores).

42-52. Narrativa (participação de Eratóstenes no regime dos Trinta).

52-61. Narrativa (traição do governo de reconciliação após a queda dos Trinta)

62-78. Narrativa (participação de Teramenes na oligarquia de 411, na paz com Esparta em 404 e na oligarquia dos Trinta em 404/3).

79-89. Provas (petição de coerência, condenação como vingança dos que foram executados pelos acusados, depreciação das testemunhas de defesa, acusação contra o júri por uma possível absolvição).

90-100. Exórdio (aos da Asty, aos do Pireu, a todos).

O discurso tradicionalmente foi entendido como uma acusação contra Eratóstenes pelo assassinato de Polemarco. No entanto, o plural usado no proêmio (acusados, crimes), e repetido por todo o discurso, demonstra que o discurso transcende 
uma ação localizada ${ }^{88}$. Os acusados são Eratóstenes, seus apoiadores e testemunhas de defesa, e os Trinta como um todo. Os crimes são o assassinato de Polemarco, a instauração da oligarquia, o exílio e execução de inocentes e a busca da ruína da cidade. Neste sentido, é possível entender a estruturação geral do discurso: se na primeira metade do discurso o orador já fez todas as acusações contra Eratóstenes, cuja completude é admitida antes, no parágrafo 37 , todo o resto do discurso funciona para associar mais fortemente Eratóstenes ao regime dos Trinta. Por exemplo, a longa depreciação de Teramenes serve para antecipar o argumento de defesa que procuraria apresentar o acusado como um oligarca moderado, por pertencer ao grupo de Teramenes: ao caracterizar este como oligarca, traidor e escravizador do povo, o orador lhe retira o status de lugar possível de argumentos a serem usados pelos antigos membros dos Trinta. Neste sentido, o discurso poderia ser divido em apenas quatro partes:

1-3. Proêmio.

4-34. Acusação de Eratóstenes pelo assassinato de Polemarco.

34-89. Associação de Eratóstenes aos Trinta.

90-100. Exórdio.

Nesta nova divisão, narrativa e prova se fundem, pois não só estes dois momentos são intercalados em todo o discurso, como a narrativa é recheada de breves interpretações e a prova é eventualmente ilustrada com breves narrativas; além disso, a própria narrativa faz parte da construção do caráter (ethos) dos personagens envolvidos, funcionando assim como argumento. A multiplicidade, riqueza e a eventual fraqueza dos argumentos presentes no discurso não serão analisados aqui sistematicamente, mas serão tratados na medida em que trouxerem dados relevantes para as questões colocadas ao discurso, como um meio de se acessar uma realidade histórica complexa. Portanto, não é nossa pretensão "esgotar" o discurso, o que aliás não parece nem possível nem desejável - antes, trata-se de um diálogo. Sendo assim, passaremos agora para a análise de duas questões: a construção das identidades e o lugar da memória no contexto da anistia de 403/2 a. C.

${ }^{88} \mathrm{O}$ que deporia a favor da hipótese de que o discurso foi produzido para a euthunai de Eratóstenes, momento onde não é tão importante especificar o crime quanto depreciar o caráter geral do acusado e seus apoiadores. 
Passemos à análise da produção das identidades ${ }^{89}$ de cidadão e meteco no discurso. É possível observar no conjunto da argumentação uma ênfase especial do orador na caracterização da conduta política dos acusados por meio de uma espécie de jogo de espelhos, ora entre o bom e o mau cidadão, ora entre o mau cidadão e o bom meteco. No meio da narrativa de sua prisão e conseqüente fuga, o orador afirma:

Eles encontraram-me [na minha casa] entretendo convidados no jantar, os retiraram, e conduziram-me a Peison. Os outros foram para a fábrica e começaram a fazer uma lista de escravos. Eu perguntei a Peison se ele aceitaria receber dinheiro em troca da minha salvação. Ele disse sim, se fosse uma grande quantia. Eu respondi que estava preparado para pagar um talento de prata, e ele concordou com esse valor. Eu sabia que ele não tinha respeito pelos deuses ou pelos homens, mas dada a minha situação, pensei ser absolutamente essencial conseguir dele um juramento. Ele jurou que ele me salvaria se recebesse a quantia, e ele invocou a destruição de si mesmo e de suas crianças. Então eu entrei no meu quarto e abri meu cofre. Peison percebeu isso e se aproximou, e ao ver seu conteúdo, ele chamou dois de seus assistentes e disse a eles para pegar tudo o que havia no cofre. [...] Eu pedi a ele algum dinheiro para minha viajem, mas ele disse que eu deveria estar grato por salvar minha pele. $(12.8-11)$.

Neste trecho, a cobiça de Peison - que é expandida, em outros momentos, para todos os Trinta -, seu desrespeito pela privacidade, sua impiedade e sua prontidão para aceitar o suborno marcam o avesso do bom cidadão. Peison age pelo interesse econômico - nem mesmo as determinações da polis, que ele e os outros Trinta governam, são capazes de barrar seus vícios. Desse modo, o mau cidadão aqui é aquele que não se submete às leis, nem divinas nem humanas, e as conseqüências são a injustiça e a impiedade. Aos metecos cabe o lugar de objetos da ação injusta dos maus cidadãos, e sua única possibilidade de manobra, diante daqueles, deriva de sua riqueza: o suborno. O regime dos Trinta aparece neste trecho sob a marca da anomia e da cobiça desenfreada. Como poderia se realizar a vida quando nenhuma lei era respeitada, seja ela do costume, seja ela da política, e nem mesmo os governantes respeitavam suas próprias determinações?

\footnotetext{
${ }^{89}$ V. discussão no cap.4, item b.
} 
A narrativa prossegue com a fuga de Lísias e a prisão e execução de Polemarco. Ao final, Lísias compara a si mesmo e sua família com os Trinta:

Não merecíamos da polis semelhante tratamento; tínhamos custeado todas as apresentações de coros requeridas, pagamos muitas contribuições militares, nos mostramos ordeiros (кобนíouৎ) e cumprimos com tudo o que nos foi requerido; não fizemos inimizades e resgatamos muitos atenienses do inimigo. E assim eles nos

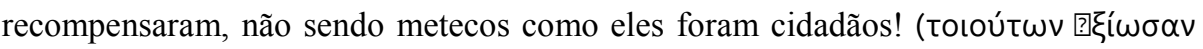

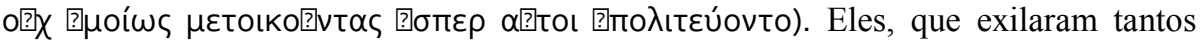
cidadãos para o meio dos inimigos; que negaram sepultura a tantas vítimas de seus crimes; que privaram tantos cidadãos de seus direitos! [...] Pois eu já lhes disse, senhores do júri, Eratóstenes matou meu irmão. Ele [Eratóstenes] não foi prejudicado, nem viu Polemarcos ofendendo a cidade. Ao contrário, Eratóstenes estava servindo seus próprios e ilegais desejos. (12.20-23).

A polis tratou injustamente a família de Lísias. Mas o que é essa polis? O orador identifica a polis à oligarquia no poder: as ações dos Trinta são as ações da polis. O resultado da oligarquia é a inversão dos valores sociais: enquanto a família de Lísias, que, sendo rica, era útil aos atenienses (na arte e na guerra) e mantinham relações sociais dentro da ordem, era perseguida e não merecia qualquer piedade, os maus cidadãos, traidores e sacrílegos, tinham total liberdade de ação. A equação aqui se dá entre a democracia/justiça, oligarquia/injustiça.

E mais do que isso. Ao narrar as diversas ligações de Teramenes com a oligarquia, Lísias nega a validade da alegação de amizade com Teramenes para conduzir o júri a absolver o acusado:

É por este homem [Teramenes], responsável por muitos atos perversos e vergonhosos, no passado ou recentemente, de natureza mesquinha ou importante, que eles [Eratóstenes e seus apoiadores] ousarão proclamar sua amizade, a despeito do fato de que Teramenes morreu devido à sua própria perversidade [...]. Tendo merecido a punição justa que ele recebeu sob a oligarquia (pois ele já havia causado sua ruína [em 411]), ele a teria merecido também sob a democracia: pois ele os

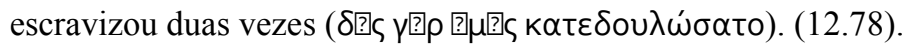

A instalação da oligarquia, como ocorreu em 411 e 404, é vista como ato de escravização do povo; a restauração democrática, por oposição, é ato de libertação. A 
equação se expande: a democracia justa fica ao lado da liberdade, a oligarquia injusta ao lado da escravidão. Acabar com a liberdade significou, na oligarquia, o desrespeito para com as leis e todos os valores sociais, liberando a ação da cobiça, invertendo a ordem democrática. Assim, no tempo da escravidão, os metecos ricos, como Lísias e sua família, não somente não recebem o devido tratamento da cidade como também são perseguidos; por oposição, no tempo da liberdade, os metecos garantem o seu lugar dentro das fronteiras da democracia.

É a norma do bom cidadão está em jogo aqui, mas, longe de ser questionada pelo orador, é reafirmada para demonstrar a superioridade dos bons metecos sobre os maus cidadãos: os bons metecos se assemelham aos bons cidadãos em seus serviços à polis, e junto deles, se opõem aos maus cidadãos. E na medida em que os maus cidadãos e suas injustiças são associados à oligarquia, os bons cidadãos e seus serviços à polis são associados à democracia. A identidade dos metecos, e particularmente dos metecos ricos que podem contribuir financeiramente com o teatro e com a guerra, se articula com a identidade da própria democracia, como regime justo, de respeito às leis divinas e humanas. O oposto das críticas oligárquicas divulgadas nos escritos do IV século, em particular nos escritos de Xenofonte e Platão, a democracia aqui se caracteriza pela soberania das leis frente à anomia oligárquica - os bons metecos partilham da identidade democrática como semelhantes aos bons cidadãos, e assim garantem sua segurança.

A associação democracia/metecos foi não apenas percebida como também combatida, como na famosa Constituição dos Atenienses escrita pelo anônimo conhecido como Velho Oligarca, na qual o autor lamenta as liberdades dos metecos no regime democrático ateniense. De qualquer modo, vemos que a produção desta identidade democrática dos metecos se dá no processo mesmo da luta contra os Trinta: é na medida em que são diretamente prejudicados pelo fím da democracia que Lísias e sua família são levados a se posicionar, e a posição assumida é a anti-oligarca.

Digno de nota, ainda, é a caracterização do júri no discurso. A imposição da subjetividade de testemunha para o júri, já iniciada no proêmio, é retomada em diversos momentos sob diversas formas. Assim, logo após narrar as traições do grupo que assumiu o governo da polis logo após a migração dos Trinta para Elêusis, que sendo escolhidos para efetuar a reconciliação, procuraram manter a oligarquia com apoio que novos reforços espartanos, o orador diz: 
Vocês [júri] estão bem conscientes de tudo o que aconteceu, e eu não sei qual a necessidade eu tenho de trazer testemunhas, mas, de todo modo, eu preciso de uma pausa, e para alguns de vocês será mais fácil ouvir a mesma história de muitos oradores. (12.61).

Em outro momento, o júri é aconselhado a ser precaver contra aqueles que defenderão o acusado:

[Eratóstenes] parece-me capaz de todo tipo de insolência quando ele vem aqui, agora, diante de juízes que não são pessoas diferentes mas as mesmas que ele tratou maldosamente, fazer sua defesa diante das próprias testemunhas de sua perversidade: tal é seu desprezo por vocês ou sua confiança em outros [seus defensores]. (12.84).

Assim, os jurados são postos, no nível da fala, à posição de testemunhas, o que também é uma convocação à memória. Entretanto, esta convocação tem seus deveres: a decisão dos jurados os implicará diretamente no quadro das oposições entre bons e maus cidadãos, entre democratas e oligarcas:

Eles [os apoiadores] dizem que Eratóstenes foi o que fez menos mal entre os Trinta, e por esta razão, eles argumentam, ele deve ser absolvido. Mas eles não percebem que ele deve ser executado porque ele fez mais mal a vocês do que todos os outros gregos? Vocês devem dar a sua opinião sobre esses assuntos. Condenando este homem, ficará claro que estão indignados com o que ocorreu. Absolvendo-o, serão vistos como tendo os mesmos objetivos que os acusados, e não poderão alegar que estavam sob ordens dos Trinta. No momento, ninguém está forçando vocês a votar contra sua consciência, então eu os aconselho a não condenarem-se ao votar pela absolvição destes homens. E não pensem que seu voto é secreto, porque farão sua opinião conhecida de toda a cidade. (89-91).

Os jurados assim são convocados a tomar posição: em tom de ameaça, o orador relembra o caráter público das decisões judiciais, e as possíveis implicações para seus responsáveis. Portanto, na medida em que os jurados são testemunhas dos crimes dos Trinta, uma absolvição seria uma declaração de cumplicidade - decidir pela condenação é aqui uma marcação identitária, alimentada pela rememoração individual e coletiva, em 
nome da democracia e contra a oligarquia. A partir do papel de "rememoradores democráticos" atribuído aos jurados pelo orador, passemos para a questão da memória. \\ Ao depreciar os eventuais defensores de Eratóstenes, Lísias afirma que: \\ É digno observar como as testemunhas, ao testemunhar por estes \\ homens [os Trinta e apoiadores], acusam-se a si mesmas: elas tomam vocês \\ como sendo singularmente esquecidos (epilesmonas) e ingênuos (euetheis), se \\ elas acreditam que por meio de vocês, o povo (plethos), conseguirão salvar os \\ Trinta com impunidade, quando devido a Eratóstenes e seus parceiros no poder \\ era perigoso até realizar funerais aos mortos. (12.87).
}

Aqui vemos o recurso à lembrança do tempo da Tirania como forma de impedir a defesa de um dos Trinta: a lembrança aqui opera como prova, transformando os jurados, cada um que se lembra e que não é ingênuo, conforme já foi dito, em testemunhas de acusação. A lembrança funciona como proteção, antídoto para as tentativas oligárquicas; por oposição, o esquecimento, jurado por oligarcas e democratas quando da restauração, é denunciado como estratégia oligárquica.

Mas não é somente na rememoração que este discurso de Lísias, digamos assim, rompe o movimento geral da anistia como esquecimento e reconciliação. $\mathrm{O}$ exórdio do discurso reproduz a cisão entre democratas e oligarcas, transposta no discurso em termos de espaço: os da asty, os do Pireu. Da memória para a cisão, a memória da cisão: o exórdio começa com a exposição do desejo de lembrar, a ambos os partidos, os desastres da oligarquia. O primeiro exórdio dirige-se aos da asty:

Primeiro, então, vocês que são os da Asty devem ter em mente que os acusados os governaram tão perversamente que vocês foram compelidos a guerrear contra seus irmãos, seus filhos, seus companheiros cidadãos, onde a derrota trouxe igualdade com os vencedores, enquanto que, tivessem vencido, vocês teriam escravizado os derrotados. Os acusados enriqueceram-se graças aos negócios públicos, enquanto suas fortunas foram reduzidas graças à guerra civil. Eles não quiseram partilhar com vocês os lucros mas os forçaram a partilhar a má reputação. (12.92-3). 
A contradição derrota/igualdade e vitória/escravidão é a expressão da inversão ocorrida na oligarquia: o corpo cívico se cinde, os cidadãos são escravizados ou exilados, e a polis passa a ser um instrumento de acumulação privada para cada um dos Trinta. A conseqüência desta inversão é o compartilhamento da má reputação, que só seria compensada pela condenação do acusado, ato que marcaria definitivamente o desligamento com o passado oligárquico. Mas de todo modo, a rememoração da cisão é parte do argumento para a condenação - o esquecimento seria positivo para a absolvição. Isso fica mais claro no exórdio aos do Pireu:

Depois de lutar em muitas guerras em solo estrangeiro, vocês foram privados de suas armas não pelo inimigo, mas pelos acusados em tempos de paz. Em seguida, relembrem como foram banidos da cidade que nossos pais nos deixaram; e quando vocês estavam no exílio, eles pediram sua extradição de outras cidades. Em compensação, demonstrem sua raiva como o fizeram na época do exílio. Relembrem também outros males que vocês sofreram nas mãos deles. Eles executaram pessoas após agarrarem-nas a força, alguns na ágora e outros em santuários; eles separaram outros de suas crianças, pais e esposas, compelindo-os a serem seus próprios assassinos, e não permitiram a eles os rituais funerários costumeiros, na crença de que sua autoridade era mais poderosa que a vingança dos deuses. Aqueles que escaparam da morte encontraram perigos em muitos lugares. Vagaram por muitas cidades e foram banidos de todas elas. Faltaram-lhes os meios necessários à vida. (12.95-7).

A rememoração aos do Pireu visa a vingança: é preciso que a memória dos sofrimentos seja reavivada, numa hipotipose que coloca aos olhos do auditório os momentos de maior privação. A memória, novamente, é arma da democracia.

Fica disso tudo que a restauração, tal como elaborada no presente discurso, não deve se basear no esquecimento, arma oligárquica, nem no ressentimento, que manteria a cisão da cidade - a democracia deve ser reconstituída com base na vingança sobre os Trinta e seus apoiadores mais diretos, para os quais o juramento do me mnesikakein não faz blindagem, e na memória do tempo invertido da oligarquia, de modo a tomar todas as precauções contra um novo ataque.

Mas a memória da restauração, deste modo constituída, colocaria diante dos cidadãos uma questão perturbadora: como interpretar a participação de não-cidadãos, escravos e metecos, direta ou indiretamente, nas lutas pela restauração da democracia? 
Não esquecer dos males passados é também lembrar dos momentos em que o corpo cívico se apresentava ao mesmo tempo cindido (democratas vs. oligarcas) e poroso (cidadãos ao lado de não-cidadãos) - como reconstituir a democracia com base na rememoração desta cisão e desta porosidade, ou seja, da lembrança da crise da polis?

O que era a polis? A historiografia, repetindo uma passagem de Aristóteles (Política,1275a), não hesitou em afirmar que a polis era uma comunidade de cidadãos homens, livres e adultos: às mulheres, crianças, escravos e metecos cabiam papéis submissos aos cidadãos, senhores de suas casas que se reconheciam como iguais na Assembléia - esta foi a visão da polis que informou, em grande medida, também os discursos filosófico e político modernos. Entretanto, a história da restauração democrática de Atenas em 403 a. C. mostra uma polis mais complexa, em uma situação de crise.

Crise da polis: é preciso especificar o sentido desta expressão. Não crise como decadência ou corrupção moral, como insistiu determinada historiografia que procurava ver no século V a Era de Ouro, o Século de Péricles, enquanto ao século IV se associavam diversas formas de declínio social, político e moral, como a demagogia, o uso de mercenários, a destruição e recuperação apenas parcial do império etc (GLOTZ, 1980). Crise aqui no sentido de que um determinado projeto de polis como equivalente a uma comunidade restrita aos cidadãos passa a ser questionado no próprio movimento de sua produção.

A polissemia do termo polis é frequentemente enfatizada pela historiografia, seja para escapar a uma tentativa de definição, que forçosamente empobreceria o conceito, seja para justificar uma escolha arbitrária, adequada aos pressupostos teóricos do historiador. Mas, para além desta variedade de sentidos, a polis tem uma existência discursiva apoiada em suportes variados, que vão do teatro à filosofia, das deliberações na Assembléia ao cotidiano judiciário. Deste modo, ao invés de somente apontar a polissemia do termo, um caminho interessante seria inserir o termo, de acordo com as situações específicas, no movimento mais amplo da sociedade, evidenciando, assim, o modo pelo qual determinadas contradições operam no nível discursivo - passamos de uma visão institucional da polis para uma visão social, regida por diversas lógicas, 
institucionais também, mas não só. "Polis" dita por um general diante da derrota iminente, por um meteco filósofo constituindo uma teoria política, por um ator em uma sátira da democracia, e muitas outras situações, responde a questionamentos $\mathrm{e}$ negociações diversos - situar estas negociações e questionamentos é reabrir as contradições encobertas pelo discurso da polis como comunidade de cidadãos (ANDRADE, 2002).

Ora, o funcionamento da definição de polis como comunidade de cidadãos assenta-se em dois princípios fundamentais: de um lado, a identidade interna entre os cidadãos, e de outro, diferença externa ao corpo cívico. Na rememoração da stasis, como se observa no Contra Eratóstenes, ambos os princípios são questionados, e a polis assume outra configuração: o corpo cívico se racha em democratas e oligarcas, os não cidadãos participam da existência pública da polis. Dito de outro modo, a identidade interna se torna cisão, a diferença externa se torna porosidade. Cisão, entre cidadãos oligarcas e democratas; porosidade, pela introdução de não-cidadãos na política e na memória.

A memória é aqui um dos palcos privilegiados desta crise, como mostra o investimento social na amnésia pelo juramento de não lembrar os males passados; a fonte judiciária evidencia o engajamento de discursos que, se aceitos, podem levar à execução ou absolvição do acusado em nome justamente dos males passados. No caso do discurso aqui recuperado, o Contra Eratóstenes de Lísias, os argumentos utilizados na acusação (re)produzem cisões e porosidades, indícios da crise da polis no pós-guerra. O tribunal se converte em Assembléia: os dois exórdios, aos da asty e aos do Pireu, transfiguram o limitado júri na direção de todos os habitantes da cidade, e assim o espaço do tribunal passa a suportar a discussão, por meio da dialética dos oradores, dos modos e conteúdos de uma política da memória.

Poderíamos arriscar explicações para essa dupla crise, como as transformações sociais e econômicas advindas do império ateniense, a urbanização da sociedade, o trauma da derrota na guerra e dissolução do Império, ou ainda a necessidade de participação massiva de não-cidadãos nos batalhões e frotas atenienses; de todo modo, é suficiente apontar as derivações desta crise no plano da consciência, que se estendem dos desenvolvimentos da retórica e seu peso político nos discursos judiciários até à formulação da ciência política de Platão e Aristóteles. Acima de tudo, o próprio conceito de polis precisa ser revisto no sentido de permitir uma visão mais complexa da 
sociedade ateniense em suas tensões, ou seja, exatamente onde o projeto cívico procura agir na forma de ocultamento e neutralização - em uma palavra, esquecimento. 


\section{Conclusão}

Ordenei que tirassem meu cavalo da estrebaria. O crido não me entendeu. Fui pessoalmente à estrebaria, selei o cavalo e montei-o. Ouvi soar à distância uma trompa, perguntei-lhe o que aquilo significava. Ele não sabia de nada e não havia escutado nada. Perto do portão ele me deteve e perguntou:

- Para onde cavalga, senhor?

- Não sei direito - eu disse -, só sei que é para fora daqui, fora daqui. Fora daqui sem parar: só assim posso alcançar meu objetivo.

- Conhece então o seu objetivo? - perguntou ele.

- Sim - respondi. - Eu já disse: "fora-daqui", é esse o meu objetivo.

- O senhor não leva provisões - disse ele.

- Não preciso de nenhuma - disse eu. - A viagem é tão longa que tenho de morrer de fome se não receber nada no caminho. Nenhuma provisão pode me salvar. Por sorte esta viagem é realmente imensa.

Franz Kafka, A Partida. 
No longo percurso da dissertação, foi defendido que os metecos atenienses participavam politicamente na polis. O que é política? O que é polis? Estas questões atravessaram a análise historiográfica, a leitura das fontes, as rediscussões teóricas. Procurou-se, a todo momento, não uma respota inequívoca, mas uma problematização adequada; procurou-se suspender as respostas mais fáceis e imediatas em nome de uma abordagem que permitisse vislumbrar uma realidade mais complexa. Uma via buscada foi a de mudar o foco historiográfico do "corpo cívico" para o "conjunto dos habitantes", e a partir disso desenvolver outras passagens: da homogeneidade à heterogeneidade, do poder à liberdade, do sistema ao cotidiano etc. A polis dos habitantes absorve a polis dos cidadãos mas não a dilui: as instituições, as exclusões, os poderem continuam. Entretanto, do ponto de vista da apropriação dos lugares da polis pelos habitantes, a polis dos cidadãos perde a sua naturalidade para aparecer dentro do quadro mais amplo da reprodução da sociedade ateniense, assim como da reprodução das contradições sociais atenienses.

A argumentação da dissertação se voltou contra tanto o discurso cívico quanto o discurso historiográfico, na medida em que este reproduzia aquele. Cidadãos e historiadores concordavam em limitar a política às instituições, em negar por princípio a participação política daqueles que não estavam institucionalmente habilitados para tal; como explicar tal concordância, num diálogo mediado por quase dois mil e quinhentos anos? Parece-me que uma chave está na questão da monopolização da política operada tanto pelas instituições da polis, na sociedade ateniense clássica, quanto nas instituições do Estado Nacional do mundo contemporâneo.

Pode-se argumentar, entretanto, que a construção de um conceito de política que ultrapassa as instituições gera um enfraquecimento do conceito: tudo vira política, da deliberação na assembléia a um aceno na rua. Acredito que não seja o caso. Em primeiro lugar, longe de enfraquecer o conceito de modo a integrar à força os nãocidadãos em seu âmbito, esta ampliação permite discutir a potência política dos habitantes, produzida em situações concretas (vida cotidiana), e que encontra no processo deliberativo institucional um de seus momentos, talvez o principal, mas certamente não o único.

Em segundo lugar, esta ampliação permite também perceber o lugar das instituições na reprodução social da polis, na medida em que o exclusivismo institucional da política deixa de ser tomado como um fato para se tornar um projeto de 
controle dos cidadãos sobre os habitantes como um todo: ao limitar a política às instituições e proibindo o acesso de não-cidadãos, os cidadãos buscam assim apagar a participação destes últimos na condução da cidade, na política. Esta limitação, no discurso cívico ateniense se torna projeto de alienação, na medida em que separa a polis dos habitantes como um todo, cidadãos ou não.

A instituição como alienação e a política como apropriação são caminhos que permitem uma aproximação entre a polis e os metecos atenienses à cidade e aos estrangeiros contemporâneos. No espaço da cidade e na construção das trajetórias de vida de imigrantes estão presentes processos de alienação que assumem aparições violentas, mas que não são, de modo algum, absolutas: políticas dos espaços urbanos e políticas de imigração apresentam os limites da alienação e apontam para as possibilidades de produção de lugares contrários às "localizações" dadas pela globalização das formas capitalistas de vida. A presente dissertação procurou os lugares da política possível dos metecos, visando uma rediscussão dos lugares possíveis da liberdade no mundo contempoâneo.

Certamente, a noção de lugar é central, e pode ser mais precisa. Lugar foi utilizado em pelo menos três sentidos. Em seu sentido mais habitual, é um "lugar no espaço": este foi o acesso à espacialidade da polis, e por aí se discutiu as potências políticas dessa espacialidade. Em outro sentido, lugar é um “topos retórico”, repositório de argumentos e valores a partir do qual o orador constrói sua argumentação; os lugares da retórica dos discursos de Lísias articulavam identidades, rediscutiam éticas e (re)produziam memórias - politicamente. Em um último sentido, lugar foi a heterotopia, a negação das subjetividades estabelecidas como normais pelas instituições e discursos cívicos, lugares da diferença onde se exercia a política como "faculdade de começar".

Uma "dissertação de mestrado" é um lugar instituído, articula-se com as estruturas sociais mais amplas, reproduz contradições, petrifica algo que em sua produção era movimento incessante. Em uma situação, em um momento em que a vida acadêmica é assolada pelo discurso da utilidade/produtividade, em que carreiras se medem por números de "linhas", em que uma corporação policial ocupa uma universidade... haveria política em uma dissertação de mestrado? 


\title{
Bibliografia
}

\author{
a) Fontes
}

ARISTÓTELES

- Constituição de Atenas (Athenaíon Politeía). Trad. de F. M. Pires. São Paulo: Hucitec, 1995.

- Política. Trad. de António Campelo Amaral e Carlos Gomes. Lisboa: Vega, 1998.

\section{DIONÍSIO DE HALICARNASSO}

- Dionysius of Halicarnassus: critical essays in two volumes. Trad. De M. Usher. London: William Heinemann (The Loeb Classical Library), 1974

\section{LÍSIAS}

- Lysias: discours. 2 vols. Trad. de L. Gernet e M. Bizos. Paris : Les Belles Lettres, 1924.

- Lysias. Trad. de W. R. M. Lamb. London: William Heinemann (The Loeb Classical Library), 1960.

- Selected Speeches. Trad. de C. Carey. Cambridge/New York: Cambridge University Press, 1989.

- Greek Orators I: Antiphon \& Lysias. Trad. de M. Edwards e S. Usher. Warminster: Aris\&Philips, 1993.

- Orazioni giudiziarie. Trad. de Elena D'Incerti Amadio. Milano: A. Modadori, 1997.

- Lysias. Trad. de Stephen C. Todd. Austin: University of Texas Press, 2000.

[PSEUDO]PLUTARCO

- Moralia X. London: William Heinemann (The Loeb Classical Library), 1995.

\section{PLATÃO}

- Fedro. Trad. P. Gomes. Lisboa: Guimarães, 1994. 
- República. Trad. Elza Marcelina. Brasília: Editora da Universidade de Brasília, 1996.

\section{TUCÍDIDES}

- História da Guerra do Peloponeso. Trad. de Mario da Gama Kury. Brasília: UNB/IPRI, 2001.

\section{XENOFONTE}

- Hellenica. Trad. de C. L. Brownson. London: William Heinemann (The Loeb Classical Library), 1918.

\section{b) Estudos}

ALLEN, D. Greek Tragedy and Law. In: GAGARIN, M. and COHEN, D. (eds). The Cambridge Companion to Ancient Greek Law. Cambridge: Cambridge University Press, 2005. pp. 374-93.

ANDRADE, M. M. de. A Vida comum - espaço, cotidiano e cidade na Atenas Clássica. Rio de Janeiro: DP\&A, 2002.

. O Tempo e os Outros: ensaio sobre História e Alteridade. In:

Boletim do CPA (UNICAMP), Campinas, v. 17, p. 7-30, jan-jun/2004.

- A Polis dos Atenienses: espaço político e políticas da diferença. Projeto apresentado ao CNPQ, 2008.

ARENDT, H. Entre o passado e o futuro. São Paulo: Perspectiva, 2005.

. A condição Humana. Rio de Janeiro: Forense Universitária, 2007.

AUSTIN, M. \& VIDAL-NAQUET, P. Economia e sociedade na Grécia Antiga. Lisboa: Edições 70, 1972.

BASLEZ, M.-F. L'étranger dans la Grèce Antique. Paris: Les Belles Lettres, 1984.

BAUMAN, Z. O Mal-estarna pós-modernidade. Rio de Janeiro: Jorge Zahar, 1998.

BEARZOT, C. Memoria e oblio, vendetta e perdono nell'Atene del 403 a. C. In:

Rivista della Scuola Superiore dell'economia e delle finanze. Roma, ano III, v.

4, pp. 6-20, 2006

BEAUD, S. \& PIALOUX, M. Rebeliões urbanas e a desestruturação das classes populares (França, 2005). In: Tempo social. São Paulo, v. 18, n. 1, junho/2006. 


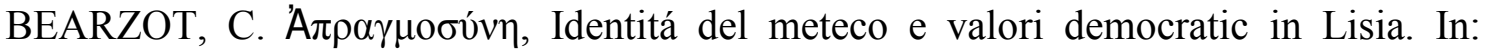
BARZANÒ, A.; BEARZOT, C.; LADUCCI, F.; PRANDI, L.; ZECCHINI, G. Identitá e Valori: fattori di aggregazione e fattori di crisi nell'esperinza politica antica: Bergamo, 16-18 dicembre 1998. Roma: “L'Erma” di Bretschneider, 2001. Diritto e Retorica nella Polis Democratica Ateniense. In: Dike: rivista di storia del Diritto Greco ed ellenistico, v. 9, 2006, pp. 129-55.

BINTLIFF, J. The Origins and Nature of the Greek City-State and its significance for World Settlement HIstory. In: RUBY, P. Les Princes de la Proto-histoire et l'émergence de l'état. Naples, 1999, pp. 43-56.

BOARDMAN, J. et alii. The oxford history of the Classical World (Greece and the Hellenistic World. Oxford/New York: Oxford University Press, 1988.

BONNER, R. J. Lawyers and litigants in ancient Athens: the genesis of the legal profession. Chicago: University of Chicago Press, 1927.

BROCK, R. and HODKINSON, S. (eds). Alternatives to Athens: Varieties of Political Organization and Community in Ancient Greece. Oxford: Oxford University Press, 2000.

BRUBAKER, R. Au-delà de l'identité. Actes de la Recherche en Sciences Sociales, n. 139, 2001, pp. 66-85.

BRUHNS, H. La cité antique de Max Weber. Opus. Rivista internazionale per la storia economica e sociale dell'antichità, VI-VIII, pp. 29-41, 1989.

BRUNA, J. Lísias, Contra Eratóstenes. In: Eloqüência grega e latina. São Paulo: Cultrix, 1969.

CALHOUN, G. M. The business life in ancient Athens. Roma: "L'Erma" di Bretschineider, 1965.

CANGUILHEM, G. O normal e o patológico. Rio de Janeiro : Forense Universitária, 2002.

CANFORA, L. La démocratie comme violence. Paris: Desjonquères, 1989. Antologia della letteratura grega. Bari: Laterza, 1990. Storia della litteratura greca. Bari, Laterza, 1996. 
CARDOSO, C. F. Economia e sociedade antigas: conceitos e debates. In: Sete

olhares sobre a Antiguidade. Brasília: Editora da Universidade de Brasília, 1998. pp.173-92.

CAREY, C. (ed.). Lysias, Selected Speeches. Cambridge: Cambridge University Press, 1989.

(ed.). Lysiae Orationes cum Fragmentis (Scriptorum Classicorum Bibliotheca Oxoniensis). Oxford: Oxford University Press, 2007.

CARLOS, A. F. A. (org.). Novos caminhos da geografia. São Paulo: Contexto, 1999.

CARTER, L. B. The Quiet Athenian. Oxford: Clarendon Press, 1986.

CARTLEDGE, P. The Greeks: a portrait or self and others. Oxford: Oxford University Press, 2002.

CARTLEDGE, P., MiLlet, P. and TODD, S. Nomos: essays in Athenian law, politics and society. Cambridge: Cambridge University Press, 1990.

CARVALHO, A. G. Historiografia e paradigmas: a tradição primitivistasubstantivista e a Grécia Antiga. Niterói: UFF, Tese de doutorado, 2007. 261 páginas.

CASSIN, B. (org.). Gregos, bárbaros e estrangeiros: a cidade e seus outros. Rio de Janeiro: Editora 34, 1993.

CERTEAU, M. de. A Invenção do cotidiano: artes de fazer. Petrópolis: Vozes, 1994.

CHARTIER, R. História cultural: entre práticas e representações. Lisboa: Difel, 1988.

CHESNAIS, F. A mundialização do capital. São Paulo: Xamã, 1996.

CHEVITARESE, A.L. Espaço rural na Pólis Grega: o caso ateniense no período clássico. Rio de Janeiro: Fábrica de Livros/SENAI-RJ, 2001.

CLERC, M. A. E. A. Les Métèques athéniens : étude sur la condition légale, la situation morale et le rôle social et économique des étrangers domiciliés à Athènes. Paris, Thorin \& fils, 1893.

CLOCHÉ, P. La restauration democratique à Athènes (en 403 avant $\mathbf{j}$-c). Paris: Ernest Leroux, 1915.

. La politique étrangère d'Athenes : de 371 a 361 avant J-C. Bruxeles : M. Lamartin, 1923.

. La civilization athénienne. Paris : Colin, 1935. 
La démocratie athénienne. Paris: Presses Universitaires de France, 1951.

COCURULlO, M. Il contributo dei papiri alla conoscenza di Lisia. Papyrologica Lupiensia, n. 10, pp. 113-170, 2001.

COHEN, D. The social context of adultery at Athens. In: CARTLEDGE, P.; MILLET, P.; TODD, S. Nomos: essays in Athenian law, politics and society. Cambridge: Cambridge University Press, 1990. pp. 147-166.

COHEN, D. J. Law, violence and community in classical Athens. Cambridge/New York: Cambridge University Press, 1995.

COHEN, E. E. The Athenian Nation. Princeton: Princeton University Press, 2000.

CONNOR, W. R.. The problem of Athenian civic identity. In: BOEGEHOLD, A. L.; SCAFURO, A. C. (ed.). Athenian identity and civic ideology. Baltimore/London, The John Hopkins University Press, 1994. pp. 34-44.

COULSON, W. (ed). The archeology of Athens and Attica under the democracy. Oxford: Oxbow Books, 1994.

CUNHA, M. C. da. A virada hispânica. In: Folha de São Paulo, São Paulo, $12 / 11 / 2006$.

DAMIANI, A. L. A crise da cidade: os termos da urbanização. In: DAMIANI, A. L., CARLOS, A. F. A., SEABRA, O. C. de L. (orgs). O espaço no fim de século: a nova raridade. São Paulo, Contexto, 1999. pp. 118-131.

. O lugar e a produção do cotidiano. In. CARLOS, A. F. A. (org.). Novos caminhos da geografia. São Paulo: Contexto, 1999.

.; CARLOS, A. F. A.; SEABRA, O. C. de L. (orgs). O espaço no fim de século: a nova raridade. São Paulo, Contexto, 2001.

DAVIES, J. K. Athenian Citizenship: the Descent Group and the Alternatives. In: RHODES, P. J. (ed). Athenian Democracy. Oxford/New York: Oxford University Press, 2004. pp. 18-39. [1a. Edição : 1977].

DÁVILA, S. Milhares de imigrantes protestam nos EUA. In: Folha de São Paulo, São Paulo, 11/04/2006. 
DEBORD, Guy. Perspectives de modifications conscientes dans la vie quotidienne. In:

Internationale Situacionniste, Paris, n. 6, ago/1961, pp. 20-27.

DEMAND, N.. Poleis on Cyprus and Oriental Despotism. In: HANSEN, M. H.; RAAFlaUB, K. (eds.). More Studies in the Ancient Greek Polis. Stuttgart: Franz Steiner Verlag, 1996. pp. 7-15.

DERRIDA, Jacques. Questão do estrangeiro: vinda do estrangeiro. In: Anne Dufourmantelle convida Jacques Derrida a falar Da Hospitalidade. São Paulo: Escuta, 2003.

DE STE. CROIX, G. E. M. The Class Struggle in the Ancient Greek World: from the Archaic Age to he Arab Conquests. London : Duckworth, 1981.

DI DONATO, Ricardo. Postface: une oeuvre, un itinéraire. In : GERNET, L. Les grecs sans miracle. Paris : La Découverte/Maspero, 1983.

DOVER, K. J. Lysias and the Corpus Lysiacum. Berkeley/Los Angeles: University of California Press, 1968.

EDWARDS, M. The Attic orators. London: Bristol Classical Press, 1994. .; USHER, S. Greek Orators I: Antiphon and Lysias. Warminster: Aris \& Phillips Ltd., 1986.

FARRAR, C. The origins of democratic thinking: the invention of politics in classical Athens. Cambridge/New York: Cambridge University Press, 1988.

FAUSTO, Ruy. Marx: lógica e política (investigações para uma reconstituição do sentido da dialética), t. II. São Paulo: Brasiliense, 1987.

FÉREZ, J. A. L. Historia de la literatura griega. Madrid: Cátedra, 1988.

FIGUEIRA, T. "Sitopolai" and "Sitophylakes" in Lysias" "Against the Graindealers": Governmental Intervention in the Athenian Economy. In: Phoenix, Vol. 40, No. 2 , 1986, pp. 149-171.

FINLEY, M. I. Política no Mundo Antigo. Rio de Janeiro: Zahar, 1985. [1ª edição: 1983].

. A Economia Antiga. Porto: Afrontamento, 1986. [1 a edição: 1973].

Os gregos antigos. Lisboa: Edições 70, 1988. 
A cidade antiga: de Fustel de Coulanges a Max Weber e além. In:

Economia e sociedade na Grécia Antiga. São Paulo: Martins Fontes, 1989. [1 ${ }^{\mathrm{a}}$ edição: 1977].

O legado da Grécia: uma nova avaliação. Brasília: EdUNB, 1998.

FLACELIÈRE, R. La vie quotidiene en Grèce au siècle de Périclès. Paris : Hachette, 1959.

FLORENZANO, Maria Beatriz B. Oikos e Polis, o público e o privado na Grécia Antiga. In: Coletâneas do nosso tempo. Hist. Rondonópolis, no. 4 e 5, 2000.

FOUCAULT, M. História da sexualidade: o uso dos prazeres. Rio de Janeiro: Graal, 1994.

A ética do cuidado de si como prática da liberdade. In: MOTA, M. B.

Michel Foucault: ética sexualidade e política. Rio de Janeiro: Forense Universitária, 2004.

FREITAG, Bárbara. Teorias da cidade. Campinas: Papirus, 2006.

FUSTEL DE COUlAnGES, N. D. A cidade antiga. $3^{\text {a }}$ edição. São Paulo: Martins Fontes, 1995. [1 ${ }^{\mathrm{a}}$ edição: 1863].

GADAMER, H. Verdade e Método. Petrópolis: Vozes, 2004.

GAGARIN, M. and COHEN, D. (eds). The Cambridge Companion to Ancient

Greek Law. Cambridge: Cambridge University Press, 2005.

GARLAN, Y. Les esclaves em grèce ancienne. Paris: La Découverte, 1982. Guerra e economia na Grécia Antiga. Campinas: Papirus, 1991.

GARLAND, R. The Piraeus: from the fifty to the first century B.C. London: Duckworth, 1987.

GARNSEY, P. D. A. Famine and Fod Supply in the Graeco-Roman World: Responses do Risk and Crisis. Cambridge: Cambridge University Press, 1988.

GAUDEMAR, J.-P. de. Mobilidade do trabalho e acumulação do capital. Lisboa : Editorial Estampa, 1977.

GERNET, Louis. Droit e société dans la Grèce Ancienne. Paris : Université de Paris, 1955.

Anthropologie de la Grèce Ancienne. Paris : Maspero, 1968. 
Droit et institutions en Grèce Antique. Paris : Flammarion, 1982.

Les grecs sans miracle. Paris : La Découverte/Maspero, 1983.

GERNET, L. ; BIZOS, M (eds. e trads.). Lysias, discours. 2 vols. Paris: Les Belles Lettres, 1924.

GINZBURG, C. Mitos, emblemas, sinais. São Paulo: Cia. das Letras, 1989.

GLOTZ, G. A cidade grega. Rio de Janeiro: DIFEL, 1980. [1ª edição: 1928].

GRECO, E. (Ed.). La città greca ântica. Roma: Donzelli, 1999.

GRESPAN, J.L. O lugar da História em tempos de crise. Revista de História, São Paulo, 151, 2004, pp. 9-27.

GUARINELLO, N. L. Uma morfologia da História: as formas da História Antiga. In: Politeia, Vitória da Conquista, v. 3, 2003, pp. 41-61. História científica, história contemporânea e história cotidiana.

Revista Brasileira de História, 24 (48), 2004, pp. 13-38.

HALL, J. M. Ethnic Identity in Greek Antiquity. Cambridge: Cambridge University Press, 1998.

- Quem eram os gregos. In: Revista do Museu de Arqueologia e Etnologia. São Paulo, no. 11, 2001, pp. 213-225.

HANSEN, M. H. The Sovereignty of the People's Court in Athens in the Fourth Century BC and the Public Action against Unconstitutional Proposals. Odense, 1974.

. The Athenian Assembly in the Age of Demosthenes. Oxford: Blackwell, 1987.

. The Political Powers of the People's Court in Fourth Century Athens. In: MURRAY, Oswyn and PRICE, Simon (ed.). The Greek City : from Homer to Alexander. Oxford : Clarendon Press, 1990, pp. 215-43.

La démocratie athénienne à l'époque de Démosthène : structure, principes et idéologie. Paris, Les Belles Lettres, 1993 [1ª edição: 1991]. 
. The 'Autonomous City-State'. Ancient fact or modern fiction? In:

HANSEN, M. H.; RAAFlAUB, K. (eds). Studies in the Ancient Greek Polis. Stuttgart: Franz Steiner Verlag, 1995. pp. 21-43.

. Polis as the generic term for State. In: NIELSEN, T. H. (ed.). Yet more studies in the Ancient Greek Polis. Stuttgart: Franz Steiner Verlag, 1997a. pp. 9-15.

A tipology of dependent poleis. In: NIELSEN, T. H. (ed.). Yet more studies in the Ancient Greek Polis. Stuttgart: Franz Steiner Verlag, 1997b. pp. 29-37.

. Polis and City-State: an ancient concept and its modern equivalent. Copenhagen: Munksgaard, 1998.

A comparative study of Thirdy City-State Cultures: a investigation conduced by the Copenhagen Polis Centre. Copenhagen: C. A. Reitzels Forlag, 2000.

; NIELSEN, T. H. An inventory of archaic and classical poleis. Oxford / New York: Oxford University Press, 2004.

HEGEL, G. Lecciones de la Filosofia de la Historia Universal. Madrid: Revista de Occidente, 1953.

HEIDEMANN, D. Os migrantes e a crise da sociedade do trabalho: humilhação secundária, resistência e emancipação. In: SERVIÇO PASTORAL DOS MIGRANTES (org). Migrações: discriminação e alternativas. São Paulo: Paulinas, 2004. pp. 25-40.

HELLER, A. Sociología de la vida cotidiana. Barcelona: Ediciones Península, 1977. . La Revolución de la vida cotidiana. Barcelona: Ediciones Península, 1982.

. O cotidiano e a história. São Paulo, Paz e Terra, 2008.

HESK, J. Deception and democracy in classical Athens. Cambridge/New York: Cambridge University Press, 2000.

HESS, R. Henri Lefebvre et la pensée de le l'espace. In: LEFEBVRE, H. La production de l'espace. $4^{\mathrm{a}}$ ed. Paris: Anthropos, 2000, pp. v-xvi. 
HESS, R. et WEIGAND, G. Henri Lefebvre et son oeuvre. In: Le Journal des Chercheurs, 2006. Disponível em $<$ http://www.barbierrd.nom.fr/H.\%20Lefebvre.pdf>, acesso em 28 abr. 2009.

HIGNETT, Charles. A History of the Athenian Constitution to the End of the Fifth Century B. C. Oxford: Clarendon Press, 1952.

HOLLOWAY, J. Mudar o mundo sem tomar o poder: o significado da revoluçã'o hoje. São Paulo: Viramundo, 2003.

HORDEN, P. and PURCELL, N. The Corrupting Sea: a study of Mediterranean history. Oxford/Massachusetts: Blackwell Publishers, 2000.

HUMPHREYS, S. C. Anthropolgy and the Greeks. London / Boston / Melbourne / Henley: Routledge \& Kegan Paul, 1978.

. Public and Private Interests in Classical Athens". In: RHODES,

P. J. (ed). Athenian Democracy. Oxford/New York: Oxford University Press, 2004. pp. 225-36. [1a. Edição: 1977].

JACQUES, P. B. (org.). Apologia da deriva. Escritos situacionistas sobre a cidade. Rio de Janeiro: Casa da Palavra, 2003.

JOLY, F.D. Capitalismo e burocracia: economia e política nas Relações Agrárias da Antiguidade, de Max Weber. In: Revista de História, 140: 9-22, 1999.

KOLB, F. La ciudad em la Antiguedad. Madrid: Ed. Gredos, 1992.

KONSTAN, D. A amizade no mundo antigo. São Paulo: Odysseus Editora, 2005.

KURZ, Robert. O Fim da Política. In: Krisis 14, Horlemann Verlag, Bad Honnef, 1994. [Versão em português disponível no site http://antivalor.vilabol.uol.com.br/textos/krisis/rkurz/tx_rkurz_050.htm].

Barbárie, migração e guerras de ordenamento mundial. In: SERVIÇO PASTORAL DOS MIGRANTES (org). Travessias na de\$ordem global: Fórum Social das Migrações. São Paulo : Paulinas, 2005. pp. 25-36.

LAMB, W. R. M. Introduction. In: LYSIAS. Lysias. Trad. de W. R. M. Lamb. Cambridge, 1960 (The Loeb Classical Library).

LEFEBVRE, H. Critique de la vie quotidienne II: fondements d'une sociologie de la quotidienneté. Paris : L’Arche Editeur, 1961. 
O direito à cidade. São Paulo: Documentos, 1969.

. La production de l'espace. Paris: Éditions Anthropos, 1974.

. A Revolução Urbana. Belo Horizonte: Editora UFMG, 2002.

. Espaço e política. Belo Horizonte, Editora UFMG, 2006.

LIMA, A. C. C. Cultura popular em Atenas no V século a. C. Rio de Janeiro : 7 Letras, 2000.

LONIS, R. La cité dans le monde grec. Paris : Nathan, 1994.

LORAUX, N. Repolitiser la cité. In: L’Homme, v.26, n. 97-98, pp. 239-55, 1986. . Comment repolitiser la cité. In: Mètis. Anthropologie des mondes grecs anciens, v. 9, n. 9-10, pp. 121-127, 1994a

. A invenção de Atenas. Rio de Janeiro: Editora 34, 1994b.

. La cité divisée: l'oubli dans la memoire d'Athènes. Paris: Éditions Payot \& Rivages, 2005.

LUCÁKS, G. Prefacio. In: HELLER, A. Sociologia de la vida cotidiana. Barcelona: Ediciones Peninsula, 1977.

. História e consciência de classe. São Paulo: Martins Fontes, 2003.

MAGALHÃES, L. O. de. Cidadania e participação política popular na democracia ateniense. In: MARTINS, I.; MOTTA, R.; IOKOI, Z. História e cidadania. Anais do XIX Simpósio Nacional de História-ANPUH, 1998.

MALACO, J. T. S. Da forma urbana: o casario de Atenas. São Paulo: Alice Foz, 2002.

O lugar da assembléia dos cidadãos de Atenas. São Paulo: Alice Foz, 2003.

MANSOURI, S. L'agora athénienne ou le lieu de travail, des discussions et des nouvelles politiques: chercher la politique là où elle n'est apparemment pas. In: Dialogues d'histoire ancienne, v. 28, n. 2, 2002, p. 41 - 63

MANVILLE, Ph. B. Toward a new paradigm of Athenian citizenship. In: BOEGEHOLD, A. L. \& SCAFURO, A. C. (ed.). Athenian identity and civic ideology. Baltimore/London, The John Hopkins University Press, 1994. pp. 2133. 
MARETT, R. R. Anthropology and the classics : six lectures delivered before the University of Oxford. New York: Barnes \& Noble, 1966.

MARTINS, J. de S. (org.). Henri Lefebvre e o retorno à dialética. São Paulo: Hucitec, 1996.

. O falso problema da exclusão social e o problema social da inclusão marginal. In: Exclusão social e a nova desigualdade. São Paulo: Paulus, 1997. pp. 25-38.

A sociabilidade do homem simples. São Paulo: Hucitec, 2000.

MARX, K. Formações econômicas pré-capitalistas. São Paulo: Paz e Terra, 1977. . O Capital. São Paulo: Nova Cultural, 1988.

MEIER, C. La naissance du politique. Paris: Gallimard, 1995. [1 $1^{\text {a }}$ edição: 1980]. . The Greeks: The Political Revolution in World History. In: RHODES, P. J. (ed). Athenian Democracy. Oxford/New York: Oxford University Press, 2004. pp. 328-48. [1 a edição: 1982].

MENESES, U. T. B. de. A cultura material no estudo das sociedades antigas. In: Revista de História, n. 115, 1983.

. A História, cativa da memória? Para um mapeamento da memória no campo das Ciências Sociais". Revista do Instituto de Estudos Brasileiros, S.Paulo, n.34, p.9-23, 1992.

" "Morfologia das cidades brasileiras: introdução ao estudo histórico da iconografia urbana". In: Revista da USP, São Paulo. no. 30., 1996, pp. 144-155.

MESQUITA, Z. e BRANDÃO, C. R. (orgs.). Territórios do cotidiano: uma introdução a novos olhares e experiências. Porto Alegre/Santa Cruz do Sul: Editora da UFRGS/Edunisc, 1995.

MEYER, Eduard. El historiador y la Historia antigua: estúdios sobre la teoria de la Historia y la Historia econômica y política de la Antigüedad. México/Buenos Aires: Fondo de Cultura Econômica, 1955. [1ª edição: 1910].

MILlET, P. Lending and borrowing in ancient Athens. Cambridge: Cambridge University Press, 1991. 
Encounters in the Agora. In: CARTELDGE, P., MILLET, P. and VON REDEN, S. (Eds.) Kosmos: essays in order, conflict, and community in classical Athens. Cambridge/New York, Cambridge University Press, 1998. pp. 203-28.

MOMIGLIANO, A. La ciudad antigua de Fustel de Coulanges. In: Ensayos de historiografía antigua y moderna. México D. F.: Fondo de Cultura Econômica, 1993.

MOSSÉ, C. Atenas: a história de uma democracia. Brasília : UnB, 1979.

MOSSÉ, C. Les métèques à Athènes. In : L'histoire, n. 44, avril 1982 [incluído em MOSSÉ (org.), 1986, pp. 270-83]. . (org.). La Grèce ancienne. Paris, Éditions du Seuil, 1986.

MOSSÉ, C. Politique et société en Grèce ancienne: le "modèle" athénien. Paris: Aubier, 1995.

. \& VIDAL-NAQUET, P. Clases y lucha de clases en la Grécia Antigua. Madrid : Akal, 1979.

MURRAY, O. Cities of Reason. In: MURRAY, O.; PRICE, S. (eds.). The Greek City : from Homer to Alexander. Oxford: Clarendon Press, 1990. pp. 1-25.

NENCI, G. Spazio civico, spacio religioso e spazio catastale nella polis. In: Annali della Scuola Superiore di Pisa, serie III, vol. IX, 1979, pp. 459-77.

NEVETT, L. C. The organization of space in Classical and Helenistic houses from mainland Greece and the western colonies. In: Spencer, N. (ed.). Time, tradition and society in Greek Archeology: bridding the "Great Divide". London/New York: Routledge, 1995.

House and society in the ancient Greek world. Cambridge: Cambridge University Press, 1999.

NOUHAUD, Michel. L'utilisation de l'histoire par les orateurs attiques. Paris: Les Belles Letres, 1982.

OBER, J. Mass and elite in democratic Athens: rethoric, ideology and power of people. Princeton: Princeton University Press, 1989. 
OBER, Josiah. The Athenian Revolution: essays on Ancient Greek democracy and political theory. Princeton: Princeton University Press, 1996.

OSBORNE, M. J. Naturalization in Athens. 4 vols. Brussels, 1981-3.

OSBORNE, R. The Demos and its divisions in Classical Athens. In: In: MURRAY, O.; PRICE, S. (eds.). The Greek City : from Homer to Alexander. Oxford: Clarendon Press, 1990. pp. 265-94.

OWEN, E. J. The city in the Greek and Roman world. London/New York: Routledge, 1996.

PATARRA, N. L. Migrações internacionais: teorias, políticas e movimentos sociais. In: Estudos Avançados, v. 20, n. 57. São Paulo, maio/agosto 2006.

PERNOT, L. La Rhétorique dans l'Antiquité. Paris : Librairie Générale Française, 2000.

POLANYI, K. Trade and market in the early empires; Economies in history and theory. New York: Free Press, 1965.

POLIGNAC, François de. La naissance de la cité grecque : cultes, espace et société VIII $^{\mathrm{e}}$-VII ${ }^{\mathrm{e}}$ siècles avant J.-C. Paris : La Découverte, 1984.

Anthropologie du Politique en Grèce Ancienne. In :

Annales : Histoire, Scienses Sociales, $52^{\mathrm{e}}$ anné, n. 1, 1997, pp. 31-9.

REIS, R. R. Migrações: casos norte-americano e francês. In: Estudos Avançados, v. 20, n. 57. São Paulo, maio/agosto 2006.

RICOEUR, P. Interpretação e Ideologias. Rio de Janeiro: Francisco Alves, 1990.

RIDER, B. C. Ancient Greek houses: their history and development from the Neolithic period to the Hellenistic age. Chicago: Argonaut, 1964.

RHODES, P. J. (ed). Athenian Democracy. Oxford/New York: Oxford University Press, 2004.

ROBERTS, J. Philosophizing the Everyday. In: Radical Philosophy, n. 98, 1999. Philosophizing the Everyday: Revoluionary Praxis and the Fate of Cultural Theory. London: Pluto Press, 2006. 
ROMÁN, C. G. Los metecos atenienses: un punto de vista sobre las clases sociales en la Antigua Atenas. In: MOSSÉ, C. \&VIDAL-NAQUET, P. Clases y lucha de clases en la Grécia Antigua. Madrid: Akal, 1979. pp. 129-159.

RONCALI, R. "Lista dei manoscritti di Eschine Licurgo Lísia". Annali della Facoltà di Lettere e Filosofia (Università degli Studi di Bari), ano xiv, pp. 379-400, 1969.

ROSTOVTZEFF, Mikhail. História da Grécia. Rio de Janeiro: Zahar Editores, 1973. [1 ${ }^{a}$ edição: 1925].

ROY, J. "The threat from the Piraeus". In: CARTLEDGE, P.; MILLETT, P.; VON REDEN, S. (eds). Kosmos: essays in order, conflict, and community in classical Athens. Cambridge/New York: Cambridge University Press, 1998.

Polis and Tribe in Classical Arkadia. In: HANSEN, M. H.; RAAFLAUB, K. (eds.). More Studies in the Ancient Greek Polis. Stuttgart: Franz Steiner Verlag, 1996. pp. 107-12.

SAGAN, E. The honey and the hemlock: democracy and paranoia in ancient Athens and modern America. Princeton: Princeton University Press, 1991.

SCHWENK, C. Athens. In: TRITLE, L. A. (org.) The Greek World in the Fourth Century: from the fall of the Athenian Empire to the sucessors of Alexander. London/New York, Routledge, 1997.

SEABRA, Cátia. Pela Coca-Cola, ministros vestem vermelho e branco no Réveillon. In: Folha de São Paulo, São Paulo, 02/01/2007.

SEAGER, R. Lysias Againt the Corndealers. In: Historia: Zeitschrift fuir Alte Geschichte, Vol. 15, No. 2 (Apr., 1966), pp. 172-184.

SINCLAIR, R. K. Democracy and participation in Athens. Cambridge: Cambridge University Press, 1993.

SILVA, S. A. da. Bolivianos em São Paulo: entre o sonho e a realidade. In: Estudos Avançados, v. 20, n. 57. São Paulo, maio/agosto 2006.

SILVA. T. T. da. A produção social da identidade e da diferença. In: SILVA, T.T.(org.) Identidade e diferença: a perspectiva dos Estudos Culturais. Petrópolis: Vozes, 2000.

SMITH, J. A. Athens under the tyrants. Bristol: Bristol Classical Press, 1989. 
SMITH, N. Geografias pós-modernas : a reafirmação do espaço na teoria social crítica. Rio de Janeiro : Bertrand Brasil, 1986.

STE. CROIX, G.E.M. de. The Class Struggle in the Ancient Greek World: from the Archaic Age to he Arab Conquests. London: Duckworth, 1981.

STRAUSS, B. Fathers and sons in Athens: ideology and society in the era of the Peloponnesian War. London: Routledge, 1993.

TERRAY, Emmanuel. Un anthropologue africaniste devant la cité grecque. In: Opus. Rivista internazionale per la storia economica e sociale dell'antichità, VI-VIII, pp. 13-26, 1989.

THOMAS, R. Oral tradiction and written record in classical Athens. Cambridge/New York, Cambridge University Press, 1989.

TODD, S. C. The use and abuse of the Attic Orators. In: Greece \& Rome, vol. xxxvii, n. 2 , oct/1990, pp. 159-178.

. The Shape of Athenian Law. Oxford: Clarendon Press, 1993.

. (trans.). Lysias (The Oratory of Classical Greece, v. 2). Austin: University of Texas, 2000

. Law and Oratory in Athens. GAGARIN, M. and COHEN, D. (eds). The

Cambridge Companion to Ancient Greek Law. Cambridge: Cambridge University Press, 2005. pp. 97-111.

A Commentary on Lysias, Speeches 1-11. Oxford and New York: Oxford University Press, 2007.

TOMLINSON, R. A. From Mycenae to Constantinople : the evolution of the ancient city. London/New York, Routledge, 1992.

TRABULSI, J. A. H. La cité grecque positiviste : anatomie d'un modèle historiographique. Paris: Harmattan, 2001a. . Ensaio sobre a mobilização política na Grécia antiga. Belo Horizonte, Editora UFMG, 2001b.

- Uma cidade de participação controlada: a 'cidade grega' segundo os positivistas. In: Benoit, H.; FUNARI, P.P.A. (Orgs.) Ética e Política no Mundo Antigo. Campinas: IFCH-Unicamp/FAPESP, 2001c. pp. 63-92. 
USHER, S. "Lysias and His Clients". Greek, Roman, and Byzantine Studies, n. 17, 1976, pp. 31-40.

UTCHENKO, S. Classes e estrutura de classes na sociedade escravista antiga. In : PINSKY, J. (org.). Modos de produção na antiguidade. $2^{\mathrm{a}}$ ed. Rio de Janeiro: Global Editora, 1984. pp. 157-68. [1 $1^{\mathrm{a}}$ edição: 1957].

VERNANT, J.-P. "Préface”. In: GERNET, L. Anthropologie de la Grèce Ancienne. Paris: Maspero, 1968.

As origens do pensamento grego. Rio de Janeiro: DIFEL, 1972. [1 ${ }^{\mathrm{a}}$ edição: 1962].

. "Préface". In: GERNET, L. Les grecs sans miracle. Paris: La Découverte/Maspero, 1983.

VICTOR, F. Sarkozy quer estrangeiros rebeldes expulsos. Folha de São Paulo, São Paulo, 10/11/2005.

VIDAL-NAQUET, P. La démocratie grecque vue d'ailleurs: essais d'historiographie ancienne et moderne. Paris, Flammarion, 1990.

VLASSOPOULOS, K. Unthinking the Greek Polis: Ancient Greek History beyond the Eurocentrism. Cambridge: Cambridge University Press, 2007.

VON REDEN, S. The Piraeus - a world apart. Greece \& Rome, 42 (1), 1995, pp. 2437.

WALlERSTEIN, I. The Modern World-System, vol. I: Capitalist Agriculture and the Origins of the European World-Economy in the Sixteenth Century. New York/London: Academic Press, 1974.

WAlKer, E. M. The Periclean Democracy. The Cambridge Ancient History, v. 5 (Athens 478-401 B. C.). Cambridge: Cambridge University Press, 1927.

WATANABE, L. Sobre o envolvimento histórico do livro I da República de Platão. In: BENOIT, H.; FUNARI, P. P. de A. (orgs.). Ética e política no mundo antigo. Campinas: UNICAMP/IFCH, 2001.

WEBER, M. Economia e Sociedade. v.1. Brasília/São Paulo: Editora UnB/Imprensa Oficial, 1999a. [1 edição: 1921]. 
Economia e Sociedade. v.2. Brasília/São Paulo: Editora UnB/Imprensa Oficial, 1999b. [1ª edição: 1921].

. A "objetividade" do conhecimento nas Ciências sociais. In: COHN, G. (org.). Max Weber: sociologia. São Paulo: Ática, 2005. pp. 75-127.

WHITEHEAD, D. The ideology of the Athenian Metic. Cambridge: The Cambridge Philological Society (Supplementary Volume no. 4), 1977.

WILL, E. Trois quarts de siècle de recherches sur l'économie grecque antique. Annales ESC, 9, (1), 1954, pp. 7-22.

WINTER, T. N. On the Corpus of Lysias. In: Classical Journal. v. 69, n. 1, pp.34-40, oct.-nov. 1973.

WOLPERT, A. Remmembering defeat. Civil War and Civic Memory in Ancient Athens. Baltimore/London: The John Hopkins University Press, 2002.

WOOD, E. M. Democracia contra capitalismo: a renovação do materialismo histórico. São Paulo: Boitempo Editorial, 2003.

WOODWARD, K. Identidade e diferença: uma introdução teórica e conceitual. In: SILVA, T. T. da. Identidade e diferença. Petrópolis: Vozes, 2000.

YUNIS, H. Taming democracy: models of political rethoric in classical Athens. Ithaca: Cornell University Press, 1996.

YUNIS, H. The Rhetoric of Law in Fourth-Century Athens. In: GAGARIN, M.; COHEN, D. (eds). The Cambridge Companion to Ancient Greek Law. Cambridge: Cambridge University Press, 2005. pp. 191-208.

ZIMMERN, A. E. The Greek Commonwealth: politics and economy in the fifthcentury Athens. New York: Oxford University Press, 1961. 